ISSN 2312-9581 (Online) ISSN 2075-1508 (Print) DOI: https://doi.org/10.15407/fsu
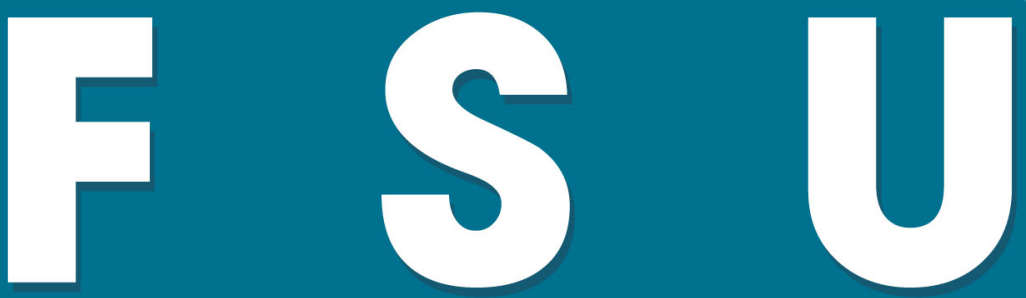

FISHERIES SCIENCE OF UKRAINE

Institute of Fisheries

of the National Academy

of Agrarian Sciences

of Ukraine 
Науковий журнал «Рибогосподарська наука України» з 2009 року входить до Переліку фахових видань України, в яких можуть публікуватися результати дисертаційних робіт на здобуття ступенів доктора і кандидата наук (біологічні та сільськогосподарські спеціальності - 091, 207), категорія «Б», переатестація від 17.03 .2020 (наказ Міністерства освіти і науки України № 409)

Засновник та видавник - Інститут рибного господарства Національної академії аграрних наук України

Свідоцтво про державну реєстрацію КВ № 20934-10734 ПР від 18.08.2014

\section{ГОЛОВНИЙ РЕДАКТОР}

Матвієнко Наталія Миколаївна, доктор біол. наук, с. н. С., зав. відділу іхтіопатології, Інститут рибного господарства HАAН, УКРАЇНА

\section{ЗАСТУПНИКИ ГОЛОВНОГО РЕДАКТОРА}

ГРИЦИНЯк Ігор Іванович, доктор с.-г. наук, професор, академік НААН, директор Інституту рибного господарства НААН, УКРАЇНА

коЛЕСНИК Наталія Леонідівна, кандидат с.-г. наук, с. н. с., зав. лаб. міжнародного науково-технічного співробітництва та інтелектуальної власності, Інститут рибного господарства НААН, УКРАїНА

\section{РЕДАКЦІЙНА КОЛЕГІЯ}

\section{БІологія}

Патрік Данієль, доктор біол. наук, голова департаменту біології Лабораторії Піренеїв, ФРАНЦУЗЬКА РЕСПУБЛІКА

Бузевич Ігор Юрійович, доктор біол. наук, с. н. С., зав. відділу вивчення біоресурсів водосховищ, Інститут рибного господарства НААН, УКРАЇНА

Бучацький Леонід Петрович, доктор біол. наук, академік Російської Академії природничих наук (РАЕН), провідний науковий співробітник лаб. біотехнологій в рибництві, Інститут рибного господарства НААН, УКРАЇНА

Діденко Олександр Володимирович, канд. біол. наук, с. н. с., відділ вивчення біоресурсів водосховищ, Інститут рибного господарства НААН, УКРАЇНА

Сондак Василь Володимирович, доктор біол. наук, зав. каф. водних біоресурсів, Національний університет водного господарства та природокористування, УКРАїНА

Рудь Юрій Петрович, канд. біол. наук, с. н. с., зав. лабораторії біотехнологій в рибництві, Інститут рибного господарства НААН, УКРАїНА

Потрохов Олександр Спиридонович, доктор біол. наук, с. н. с., зав. лаб. біології відтворення риб, Інститут гідробіології НАН України, УКРАїНА

Кутіщев Павло Сергійович, канд. біол. наук, зав. каф. водних біоресурсів та аквакультури, Херсонський державний аграрний університет, УКРАїНА

Драган Людмила Петрівна, канд. біол. наук, с. н. с., зав. лаб. екологічних досліджень, Інститут рибного господарства НААН, УКРАЇНА

Кружиліна Світлана Володимирівна, канд. біол. наук, с. н. с., зав. сектору відділу вивчення біоресурсів водосховищ, Інститут рибного господарства НААН, УКРАЇНА

Маренков Олег Сергійович, канд. біол. наук, доцент каф. загальної біології та водних біоресурсів, Дніпровський національний університет імені Олеся Гончара, УКРАЇНА

\section{ВОДНІ БІОРЕСУРСИ ТА АКВАКУЛЬТУРА}

Гомельський Борис, доктор біол. наук, професор, Державний Університет Кентуккі, СПОЛУЧЕНІ ШТАТИ АМЕРИКИ Ху Пао, доктор с.-г. наук, професор, директор Центру прісноводного рибного господарства, КИТАЙСЬКА НАРОДНА РЕСПУБЛІКА

Крупінські Єджей, доктор с.-г. наук, професор, іноземний член Національної академії аграрних наук України, директор, Інститут зоотехнії Польщі, ПОЛьщА

Зодапе Гаутам В., доктор біол. наук, професор, декан факультету зоології Державного Університету Шиваджи в Колхапурі, РЕСПУБЛІКА ІНДІЯ

Третяк Олександр Михайлович, доктор с.-г. наук, с. н. С., заступник директора з наукової роботи, Інститут рибного господарства НААН, УКРАЇНА

Тарасюк Сергій Іванович, доктор с.-г. наук, професор, член-кор. НААН, Інститут рибного господарства НААН, УКРАÏ̈А

Бех Віталій Валерійович, доктор с.-г. наук, професор, каф. аквакультури, Національний університет біоресурсів і природокористування, УКРАЇНА

Костенко Олександр Іванович, канд. с.-г. наук, с. н. С., зав. відділу ветеринарної медицини та зоотехнії, Національна академія аграрних наук України, УКРАїНА

Шарамок Тетяна Сергіївна, канд. с.-г. наук, доцент каф. загальної біології та водних біоресурсів, Дніпровський національний університет імені Олеся Гончара, УКРАїНА

Чепіль Людмила Василівна, канд. с.-г. наук, доцент каф. біології тварин, Національний університет біоресурсів і природокористування, УКРАїНА

Жигмонд Женей, доктор с.-г. наук, професор, Паннонський університет, УГОРЩИНА

Бреус Денис Сергійович, канд. с.-г. наук, доцент каф. екології та сталого розвитку імені професора Ю.В. Пилипенка, Херсонський державний аграрний університет, УКРАÏHA

\section{НАУКОВІ РЕДАКТОРИ РОЗДІЛІВ}

є штатними працівниками Інституту рибного господарства НААН України: Тушницька Наталія Йосифівна, канд. вет. наук, с. н. С., вчений секретар IPГ НААН; Тучапський Ярослав Васильович, канд. с.-г. наук, с. н. с. відділу селекції риб ІРГ НААН; Залоїло Ольга Василівна, канд. біол. наук, с. н. с., зав. лаб. молекулярно-генетичних досліджень IPГ НААН; Забитівський Юрій Михайлович, канд. біол. наук, с. н. с., заступник директора Львівської дослідної станції IPГ НААН; Мрук Антоніна Іванівна, зав. лаб. лососівництва IPГ НААН; Григоренко Тетяна Володимирівна, канд. с.-г. наук, зав. лаб. гідробіології та технологій культивування цінних безхребетних IPГ НААН; Куріненко Ганна Анатоліївна, канд. с.-г. наук, зав. відділу селекції риб ІРГ НААН.

Редакція журналу «Рибогосподарська наука України»: вул. Обухівська, 135, м. Київ-164, 03164 тел.: +38(097) 700-77-25; http://fsu.ua; Емаил: fsu.journal@gmail.com

Підписано до друку 25.05.2020 р. Формат 70×108/16. Друк офсетний. Ум. друк. арк. 7,1. Наклад 500 прим. Журнал друкується за рішенням вченої ради Інституту рибного господарства НААН (Протокол №3 від 25.05.2020 р.) Дизайн макету: Колесник Н. Л., Шинкар С. В., Архангельський Є. Ю., Безусий О. Л.

Верстка: Архангельський Є. Ю., Симон М. Ю. Літературне редагування: Швець Т. М. Коректор: Ковальчук Г. В. Друкарня ТОВ «ПРО ФОРМАТ», 02166, м. Київ, вул. Маршала Жукова, 45 Б, оф. 16, тел.: +38(044) 353-85-58 


\section{PИБОГОСПОДАРСВКА}

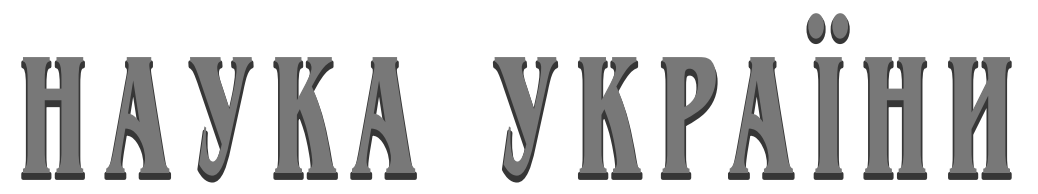

НАУКОВИЙ ЖУРНАЛ

Заснований у $2007 \mathrm{p}$.

Виходить 4 рази на рік

\section{2/2020(52)}

Ribogospod. nauka Ukr., 2020; 2(52): 1-128

DOI: https://doi.org/10.15407/fsu2020.02

\section{M I C T}

\section{БІОРЕСУРСИ ТА ЕКОЛОГІЯ ВОДОЙМ}

Ribogospod. nauka Ukr., 2020; 2(52): 5-17

DOI: https://doi.org/10.15407/fsu2020.02.005

I. І. Абрам'юк, С. О. Афанасьєв, О. О. Гупало, О. М. Лєтиџька,

Н. В. Тимошенко

Особливості іхтіофауни басейну річки Стрий

Ribogospod. nauka Ukr., 2020; 2(52): 18-28

DOI: https://doi.org/10.15407/fsu2020.02.018

П. В. Шекк, Ю. О. Астафуров

Дослідження щільностей скупчення східної прісноводної креветки

(Macrobranchium nipponense De Haan, 1849) в басейні нижнього

Дністра

\section{ТЕХНОЛОГІЇ В АКВАКУЛЬТУРІ}

Ribogospod. nauka Ukr., 2020; 2(52): 29-37

DOI: https://doi.org/10.15407/fsu2020.02.029

О. М. Третяк, М. М. Пашко, О. М. Колос

Вирощування личинок стерляді (Acipenser ruthenus Linnaeus, 1758)

у нетрадиційні строки

\section{КОРМИ ТА ГОДІВЛЯ}

Ribogospod. nauka Ukr., 2020; 2(52): 38-52

DOI: https://doi.org/10.15407/fsu2020.02.038

Р. А. Паламарчук, О. В. Дерень, С. А. Коба

Продуктивні та відтворні показники коропа за введення до складу

корму амаранта.

Ribogospod. nauka Ukr., 2020; 2(52): 53-64

DOI: https://doi.org/10.15407/fsu2020.02.053

В. В. Бех, В. П. Маризенюк, Н. Й. Тушниизька

Перспективи використання білкових компонентів нетрадиційного походження в комбікормах для аквакультури (огляд)

(C) Інститут рибного господарства НААН України, 2020 


\section{ІХТІОПАТОЛОГІЯ}

Ribogospod. nauka Ukr., 2020; 2(52): 65-77

DOI: https://doi.org/10.15407/fsu2020.02.065

Л. П. Бучацький, Ю. П. Рудь, О. В. Залоӥло, І. А. Залоїло, І. І. Грициняк

Нідовірусні інфекції риб та креветок (огляд)

\section{ЕКОНОМІКА}

Ribogospod. nauka Ukr., 2020; 2(52): 78-85

DOI: https://doi.org/10.15407/fsu2020.02.078

М. Ю. Симон, Г. А. Куріненко, Н. Л. Колесник

Економічна ефективність вирощування ранньої молоді російського осетра (Acipenser gueldenstaedtii Brandt \& Ratzeburg, 1833) за ведення до раціону інактивованих пекарських дріжджів

\section{СТОРІНКА МОЛОДОГО ВЧЕНОГО}

Ribogospod. nauka Ukr., 2020; 2(52): 86-96 DOI: https://doi.org/10.15407/fsu2020.02.086

О. О. Батуревич, Т. О. Берсан

Продуктивна та економічна ефективність вирощування товарного

коропа за використання в годівлі нетрадиційних кормових добавок.

\section{КРИТИКА І БІБЛІОГРАФІЯ}

Ribogospod. nauka Ukr., 2020; 2(52): 97-128

DOI: https://doi.org/10.15407/fsu2020.02.097

I. Й. Грициняк, Т. М. Швец̧ь

Полікультура в рибництві. Тематична бібліографія 


\section{СОДЕРЖАНИЕ}

\section{БИОРЕСУРСЫ И ЭКОЛОГИЯ ВОДОЕМОВ}

Ribogospod. nauka Ukr., 2020; 2(52): 5-17

DOI: https://doi.org/10.15407/fsu2020.02.005

И. И. Абрамюк, С. А. Афанасьев, Е. А. Гупало, Е. Н. Летиџкая, Н. В. Тимоменко

Особенности ихтиофауны бассейна реки Стрый.

Ribogospod. nauka Ukr., 2020; 2(52): 18-28

DOI: https://doi.org/10.15407/fsu2020.02.018

П. В. Шекк, Ю. А. Астафуров

Исследования плотности скоплений восточной пресноводной креветки

(Macrobranchium nipponense De Haan, 1849) в бассейне нижнего Днестра.

\section{ТЕХНОЛОГИИ В АКВАКУЛЬТУРЕ}

Ribogospod. nauka Ukr., 2020; 2(52): 29-37

DOI: https://doi.org/10.15407/fsu2020.02.029

А. М. Третяк, М. М. Пашко, Е. Н. Колос

Выращивание личинок стерляди (Acipenser ruthenus Linnaeus, 1758)

в нетрадиционные сроки

\section{КОРМА И КОРМЛЕНИЕ}

Ribogospod. nauka Ukr., 2020; 2(52): 38-52

DOI: https://doi.org/10.15407/fsu2020.02.038

Р. А. Паламарчук, О. В. Дерень, С. А. Коба

Продуктивные и репродуктивные показатели карпа при введении в состав корма амаранта

Ribogospod. nauka Ukr., 2020; 2(52): 53-64

DOI: https://doi.org/10.15407/fsu2020.02.053

В. В. Бех, В. П. Мариенюк, Н. И. Тушницкая

Перспективы использования белковых компонентов нетрадиционного

происхождения в комбикормах для аквакультуры (обзор).

\section{ИХТИОПАТОЛОГИЯ}

Ribogospod. nauka Ukr., 2020; 2(52): 65-77

DOI: https://doi.org/10.15407/fsu2020.02.065

Л. П. Бучаикий, Ю. П. Рудь, О. В. Залоило, И. А. Залоило, И. И. Грициняк

Нидовирусные инфекции рыб и креветок (обзор)

\section{ЭКОНОМИКА}

Ribogospod. nauka Ukr., 2020; 2(52): 78-85

DOI: https://doi.org/10.15407/fsu2020.02.078

М. Ю. Симон, А. А. Куриненко, Н. Л. Колесник

Экономическая эффективность выращивания ранней молоди русского осетра (Acipenser gueldenstaedtii Brandt \& Ratzeburg, 1833) при введении в рацион

инактивированных пекарских дрожжей.....

\section{СТРАНИЦА МОЛОДОГО УЧЕНОГО}

Ribogospod. nauka Ukr., 2020; 2(52): 86-96

DOI: https://doi.org/10.15407/fsu2020.02.086

О. А. Батуревич, Т. А. Берсан

Продуктивная и экономическая эффективность выращивания товарного карпа при использовании в кормлении нетрадиционных кормовых добавок

\section{КРИТИКА И БИБЛИОГРАФИЯ}

Ribogospod. nauka Ukr., 2020; 2(52): 97-128

DOI: https://doi.org/10.15407/fsu2020.02.097

Ир. И. Грициняк, Т. М. Швец

Поликультура в рыбоводстве. Тематическая библиография 


\section{O N T E N T S}

\section{BIORESOURCES AND ECOLOGY OF WATER BODIES}

Ribogospod. nauka Ukr., 2020; 2(52): 5-17

DOI: https://doi.org/10.15407/fsu2020.02.005

I. Abramiuk, S. Afanasyev, O. Hupalo, O. Lietitska, N. Tymoshenko

Characteristics of fish fauna in the Stryi river catchment

Ribogospod. nauka Ukr., 2020; 2(52): 18-28

DOI: https://doi.org/10.15407/fsu2020.02.018

P. Shekk, Yu. Astafurov

Density of location of the eastern freshwater shrimps (Macrobranchium nipponense

De Haan, 1849) in the lower river basin Dnister

\section{TECHNOLOGIES IN AQUACULTURE}

Ribogospod. nauka Ukr., 2020; 2(52): 29-37

DOI: https://doi.org/10.15407/fsu2020.02.029

A. Tretiak, M. Pashko, Ye. Kolos

Rearing sterlet (Acipenser ruthenus Linnaeus, 1758) larvae in non-traditional periods

\section{FEEDS AND FEEDING}

Ribogospod. nauka Ukr., 2020; 2(52): 38-52

DOI: https://doi.org/10.15407/fsu2020.02.038

R. Palamarchuk, O. Deren, S. Koba

Productive and reproductive parameters of carp when adding amaranth seeds

to fish feed

Ribogospod. nauka Ukr., 2020; 2(52): 53-64

DOI: https://doi.org/10.15407/fsu2020.02.053

V. Bekh, V. Martseniuk, N. Tushnytska

Outlook of using protein components of non-traditional origin in aquaculture feeds (review)

\section{ICHTHYOPATHOLOGY}

Ribogospod. nauka Ukr., 2020; 2(52): 65-77

DOI: https://doi.org/10.15407/fsu2020.02.065

L. Buchatsky, Yu. Rud, O. Zaloilo, I. Zaloilo, I. Hrytsyniak

Nidoviral infections of fish and prawn: a review.

\section{ECONOMICS}

Ribogospod. nauka Ukr., 2020; 2(52): 78-85

DOI: https://doi.org/10.15407/fsu2020.02.078

M. Simon, H. Kurinenko, N. Kolesnik

Economic efficiency of growing early juveniles of Russian sturgeon (Acipenser gueldenstaedtii Brandt \& Ratzeburg, 1833) with the introduction in the diet inactivated baker's yeast

\section{YOUNG SCIENTIST PAGE}

Ribogospod. nauka Ukr., 2020; 2(52): 86-96 DOI: https://doi.org/10.15407/fsu2020.02.086

O. Baturevych, T. Bersan

Productive and economic efficiency of rearing table carp with the use of non-traditional feed additives

\section{CRITICISM AND BIBLIOGRAPHY}

Ribogospod. nauka Ukr., 2020; 2(52): 97-128 DOI: https://doi.org/10.15407/fsu2020.02.097

Ir. Hrytsynyak, T. Shvets

Polyculture in fisheries. Thematic bibliography 


\section{БІОРЕСУРСИ ТА ЕКОЛОГІЯ ВОДОЙМ}

Ribogospod. nauka Ukr., 2020; 2(52): 5-17

DOI: https://doi.org/10.15407/fsu2020.02.005

УДК 597.2/.5(282.247.314)
Received 13.02.20

Received in revised form 14.03.20

Accepted 11.04.20

\section{ОСОБЛИВОСТІ ІХТІОФАУНИ БАСЕЙНУ РІЧКИ СТРИЙ}

І. І. Абрам’юк, abrmyk@уahoo.com, Інститут гідробіології НАН України, м. Київ

С. О. Афанасьєв, safanasyev@ukr.net, Інститут гідробіології НАН України, м. Київ

О. О. Гупало, cloudy@ukr.net, Інститут гідробіології НАН України, м. Київ

О. М. Лєтицька, lietitska@ukr.net, Інститут гідробіології НАН України, м. Київ

Н. В. Тимошенко, natali tim@i.ua, Інститут гідробіології НАН України, м. Київ

Мета. Встановити сучасний видовий склад риб та провести аналіз структури іхтіофауни басейну річки Стрий на основі матеріалів польових досліджень, опублікованих праць та даних опитування.

Методика. Іхтіологічні дослідження проводили у 2017-2019 рр. на р. Стрий, а також ї̈ притоках - Рибник, зубриця, Східниця і Опір. Дорослих риб ловили за допомогою гачкових снастей та сачків, личинок та мальків - за допомогою малькових сачків та ікорних сіток. Визначення видів та морфологічний аналіз риб проводили за стандартними методиками. Неповний біологічний аналіз більшості риб, зокрема всіх особин червонокнижних видів, здійснювали безпосередньо на місці лову з подальшим поверненням ї живими у річку.

Результати. Отримані дані засвідуують наявність у р. Стрий щонайменше 27 видів риб, що належать до 8 родин. в іхтіофауні переважають типові річкові (реофільні) види. Лімнофільні види в умовах гірської річки зустрічалися досить рідко, так само обмеженим на даний час $є$ поширення інвазивних видів. Іхтіофауна Стрия має риси ендемізму $і$ реліктовості. 6 видів занесені до Червоної книги України, 10 - до списків Бернської конвенції. Більшість представників іхтіофауни р. Стрий здійснюють досить далекі міграції як в межах основного русла, так і його приток. Для збереження аборигенної річкової іхтіофауни, зокрема раритетних видів риб, необхідно уважно підходити до будь-якої господарської діяльності в межах річкового басейну, яка порушує природний гідрологічний режим або призводить до забруднення води.

Наукова новизна. Вперше проведено комплексне дослідження іхтіофауни річки Стрий, проаналізовано поширення рідкісних та зникаючих, а також інвазивних видів риб.

Практична значимість. Одержані дані є необхідними при плануванні заходів щодо рідкісних та зникаючих видів риб, регулюванні любительського рибальства. Результати роботи було використано в рамках оцінки впливу на довкілля будівництва малих ГЕС на $р$. Стрий. Відомості щодо складу іхтіофауни, поширення рідкісних та зникаючих риб, зокрема тих, що здійснюють нерестові міграції, важлив враховувати при плануванні будь-яких видів господарської діяльності, які порушують морфологію русла та гідрологічний режим річки (забір гравію, одамбування, берегоукріплення, спорудження гребель тощо).

Ключові слова: іхтіофауна, гірські річки, річка Стрий, види, що охороняються, інвазивні види.

(C) І. І. Абрам'юк, С. О. Афанасьєв, О. О. Гупало, О. М. Лєтицька,

Н. В. Тимошенко, 2020 


\title{
CHARACTERISTICS OF FISH FAUNA IN THE STRYI RIVER CATCHMENT
}
I. Abramiuk, abrmyk@yahoo.com, Institute of Hydrobiology NAS of Ukraine, Kyiv
S. Afanasyev, safanasyev@ukr.net, Institute of Hydrobiology NAS of Ukraine, Kyiv
O. Hupalo, cloudy@ukr.net, Institute of Hydrobiology NAS of Ukraine, Kyiv
O. Lietitska, lietitska@ukr.net, Institute of Hydrobiology NAS of Ukraine, Kyiv
N. Tymoshenko, natali tim@i.ua, Institute of Hydrobiology NAS of Ukraine, Kyiv

Purpose. To determine the current species composition of fish and analyze the structure of ichthyofauna of the Stryi River catchment on the basis of field studies, published works and survey data.

Methodology. Ichthyological studies were carried out in 2017-2019 on the Stryi river, as well as its tributaries Rybnik, Zubrytsya, Skhidnytsia and Opir. Adult fish were caught using hook and line gear and hand nets, the larvae and fry were collected using sweep nets and plankton nets. Species identification and morphological analysis of fish were performed according to standard methods. Incomplete biological analysis of most fish, including all individuals of the Red book species, was carried out in situ, with fish being subsequently released in the river.

Findings. The data obtained indicate that at least 27 fish species belonging to 8 families are present in the Stryi river. The typical riverine (rheophilic) species predominate in fish fauna. The limnophilic species in conditions of mountain river are rare, and the distribution of invasive species is limited for now. Ichthyofauna of the Stryi has features of endemism and relictism. 6 species are listed in the Red Book of Ukraine, 10 are in the Berne Convention. Most fishes carry out long-range migrations within the main channel as well as its tributaries. In order to preserve native riverine ichthyofauna, in particular the rare fish species, it is necessary to carefully approach any economic activity within the river basin which disrupts the natural hydrological regime or leads to water pollution.

Originality. For the first time, a comprehensive study of fish fauna in the Stryi River was conducted, the distribution of rare and endangered as well as invasive fish species, was analyzed.

Practical value. The data obtained are necessary for planning measures for the protection of rare and endangered fish species and for the regulation of recreational fisheries. The results of this study were used as a part of the environmental impact assessment of small hydroelectric power plants construction on the Stryi River. Information on the ichthyofauna composition, the distribution of rare and endangered fishes, particularly those, which undertake spawning migrations, is important for consideration when planning any economic activity that disrups the morphology and hydrological regime of the river bed (gravel extraction, bank stabilization, damming etc.).

Key words: ichthyofauna, mountain rivers, the Stryi River, protected species, invasive species.

\section{ОСОБЕННОСТИ ИХТИОФАУНЫ БАССЕЙНА РЕКИ СТРЫЙ}

\author{
И. И. Абрамюк, abrmyk@yahoo.com, Институт гидробиологии НАН Украины, \\ г. Киев \\ С. А. Афанасьев, safanasyev@ukr.net, Институт гидробиологии НАН Украины, \\ г. Киев \\ Е. А. Гупало, cloudy@ukr.net, Институт гидробиологии НАН Украины, г. Киев \\ Е. Н. Летицкая, lietitska@ukr.net, Институт гидробиологии НАН Украины, г. Киев \\ Н. В. Тимошенко, natali tim@i.ua, Институт гидробиологии НАН Украины, г. Киев
}

Цель. Установить современный видовой состав рыб и провести анализ структуры ихтиофауны бассейна реки Стрый на основе материалов полевых исследований, опубликованных работ и опросных данных.

Методика. Ихтиологические исследования проводили в 2017-2019 г2. на р. Стрый, а также ее притоках - Рыбник, зубрица, Схидница и Опир. Взрослых рыб ловили с помощью

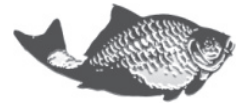


крючковых снастей и сачков, личинок и мальков - с помощью мальковых сачков и икорных сетей. Определение видов и морфологический анализ рыб проводили по стандартным методикам. Неполный биологический анализ большинства рыб, в том числе всех особей краснокнижных видов, осуществляли непосредственно на месте ловли с последующим возвращением их живыми в реку.

Результаты. Полученные данные свидетельствуют о наличии в р. Стрый не менее 27 видов рыб, относящихся к 8 семействам. В ихтиофауне преобладают типичные речные (реофильные) виды. Лимнофильные виды в условиях горной реки встречались довольно редко, также ограниченным в настоящее время является распространение инвазивных видов. Ихтиодауна Стрыя имеет черты эндемизма и реликтовости. 6 видов занесены в Красную книгу Украины, 10 - в списки Бернской конвенции. Большинство представителей ихтиофауны р. Стрый осуществляют довольно дальние миграции как в пределах основного русла, так и его притоков. Для сохранения аборигенной речной ихтиофауны, в частности раритетных видов рыб, необходимо внимательно подходить к любой хозяйственной деятельности в пределах речного бассейна, которая нарушает естественный гидрологический режим или приводит к загрязнению воды.

Научная новизна. Впервые проведено комплексное исследование ихтиофауны реки Стрый, проанализировано распространение редких и исчезающих, а также инвазивных видов рыб.

Практическая значимость. Полученные данные необходимы при планировании мероприятий по охране редких и исчезающих видов рыб, регулировании любительского рыболовства. Результаты работы были использованы в рамках оценки воздействия на окружающую среду строительства малых ГЭС на р. Стрый. Сведения о составе ихтиофауны, распространении редких и исчезающих рыб, в частности тех, которые осуществляют нерестовые миграции, важно учитывать при планировании любых видов хозяйственной деятельности, которые нарушают морфологию русла и гидрологический режим реки (забор гравия, одамбирование, берегоукрепление, строительство плотин и т.д.).

Ключевые слова: ихтиофауна, горные реки, река Стрый, охраняемые виды, инвазивные виды.

\section{ПОСТАНОВКА ПРОБЛЕМИ ТА АНАЛІЗ ОСТАННІХ ДОСЛІДЖЕНЬ І ПУБЛІКАЦЙ}

Річки Українських Карпат характеризуються високим таксономічним багатством гідробіонтів, зокрема й іхтіофауни. Перш за все це зумовлено різноманіттям умов завдяки неоднорідному рельєфу і значному перепаду висот. Швидкі верхні ділянки річок 3 холодною, насиченою киснем водою $\epsilon$ сприятливими для життя реофільних риб, зокрема лососевих, в той час як нижні ділянки 3 широкими долинами, де менша швидкість течії і вища температура води, слугують середовищем існування не тільки для річкових, але й для риб лімнофільної групи. Важливе місце серед карпатських річок посідають правобережні притоки Дністра, найбільш повноводною з яких є річка Стрий.

Стрий протікає в межах Сколівського, Турківського, Дрогобицького, Стрийського та Жидачівського районів Львівської області, довжина річки складає

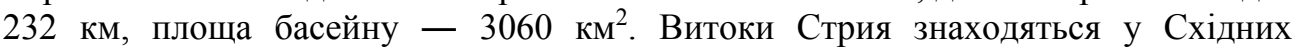
Карпатах на схилі гори Явірник. У верхів ї Стрий - типова гірська річка, тече у каньйоноподібній долині. Нижче м. Турки долина поступово розширюється, набуваючи в межах Передкарпаття рівнинного характеру. Заплава у середній та нижній течії двостороння, в пониззі місцями заболочена. Річище дуже звивисте, часто розгалужене, на кам'янистих ділянках порожисте. У верхній течії русло 
річки завширшки 10-30 м, в середній - 50-80 м, а у пониззі розширюється до 150 м. Похил Стрия складає 3,2 м/км. Річка відносно неглибока, звичайна глибина - від 0,5 до 1,0 м, але трапляються і ями до 3,0 м. Швидкість течії - 0,1-2,0 м/с. Неподалік від м. Жидачева Стрий впадає у Дністер. У цьому місці він навіть повноводніший за Дністер, але все одно залишається його притокою $[1,2]$.

Основними джерелами живлення річки Стрий є дощові і талі снігові води. Для річки характерні весняне водопілля та літньо-осінні (іноді зимові) паводки, під час яких рівень води швидко зростає і потім падає. Середня витрата води за 17 км від гирла $-45,2 \mathrm{~m}^{3} / \mathrm{c}$, максимальна $-890 \mathrm{~m}^{3} / \mathrm{c}$. Середня літня температура води - до $+20^{\circ} \mathrm{C}$, зимова - до $-6^{\circ} \mathrm{C}$. Льодостав триває переважно 3 кінця листопада до середини березня. Стрий має 31 притоку, найбільшою 3 яких $є$ р. Опір $[1,2]$.

Протікаючи через низку населених пунктів, річка Стрий відіграє дуже важливу роль як джерело води для господарських та промислових потреб, а також як цінний об'єкт відпочинку і риболовлі як для місцевого населення, так і для туристів. Однак, розташування поселень уздовж річки негативно впливає на іiі стан: стічні води та сміття погіршують санітарні показники, а модифікація берегів, одамбування, видобування гравію, зарегулювання стоку та інша діяльність в межах річки порушують її гідрологічний режим. Всі ці чинники зрештою позначаються на стані чутливої річкової біоти, зокрема і рибної фауни.

\section{ВИДІЛЕННЯ НЕВИРІШЕНИХ РАНІШЕ ЧАСТИН ЗАГАЛЬНОЇ ПРОБЛЕМИ. МЕТА РОБОТИ}

Останніми роками в іхтіофауні багатьох регіонів, зокрема й Українських Карпат, відбулись суттєві зміни, які призвели до порушень структури i функціонування прісноводних екосистем, угруповань і популяцій окремих видів риб, деградації і спрощення біоти, скорочення кількості біотопів. Тому важливо не лише оцінити сучасну іхтіофауну водотоків та водойм, але й простежити динамічні процеси, що відбуваються в їхніх екосистемах. Крім того, знання видового складу риб, іхтіофауністичних відмінностей, екологічних та біологічних особливостей популяцій риб може слугувати необхідним науковим підгрунтям для вирішення низки прикладних завдань. Проведене дослідження дасть можливість більш предметно підійти до вирішення питання про ступінь забруднення карпатських водойм, обгрунтувати заходи щодо покращення охорони нерестовищ, окреслити перспективи робіт 3 відновлення популяцій рідкісних видів риб.

Незважаючи на те, що Стрий є важливою притокою Дністра 3 точки зору водокористування та рекреації, зокрема і рибальства, ступінь вивчення його рибного населення вкрай низький. Інформація про іхтіофауну річки обмежена незначною кількістю нотаток від рибалок на різних інтернет-ресурсах, згідно 3 якими у річці мешкає близько 30 видів риб [2, 3]. Опублікованих праць конкретно про іхтіофауну Стрия практично немає, за винятком описів фрагментарних зборів на окремих ділянках річки, що зберігаються у Зоологічному музеї НАНУ, де налічується всього 12 видів риб [4].

У зв'язку з наведеним вище, мета даної роботи - встановити сучасний видовий склад риб і провести аналіз структури іхтіофауни басейну річки Стрий на основі матеріалів польових досліджень, опублікованих робіт та даних опитувань.

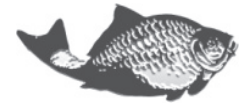




\section{МАТЕРІАЛИ ТА МЕТОДИ}

Матеріал зібрано в 2017-2019 рр. (квітень, травень, липень, вересень). Дослідженнями охоплено русло річки Стрий від с. Ропавське (гірська частина) до гирла, а також іiї притоки Рибник (включно з притокою другого порядку Зубриця), Східниця та Опір. Натурні дослідження включали в себе пошук сучасних місць нагулу, нересту і зимівлі, а також вивчення покатних міграцій молоді риб.

Риб відловлювали як на основному руслі, так і в протоках, затоках та старицях за допомогою різноманітних дозволених знарядь та методів лову. Для вилову дорослих риб використовували гачкові знаряддя (поплавцеві і донні вудки, спінінги) та сачки 3 діаметром кільця 45 см і вічком 0,5 см. Для лову личинок та мальків застосовували ікорну сітку з прямокутним вхідним отвором $(1 \times 0,25$ м, конус довжиною 1,6 м 3 млинового сита № 11) і мальковий сачок (діаметр 0,35 м, конус із сита № 14).

Морфобіологічний аналіз проводили за загальноприйнятими методами [5]. Для видової ідентифікації дорослих риб, личинок та мальків використовували відповідні визначники [6- 8]. Систематика видів наведена за Ю. В. Мовчаном [7]. Більшість риб, зокрема і всі екземпляри червонокнижних видів, після вимірювання довжини та зважування були відпущені у річку живими.

\section{РЕЗУЛЬТАТИ ДОСЛІДЖЕНЬ ТА ЇХ ОБГОВОРЕННЯ}

На підставі наших уловів та додаткових даних на теперішній час можна стверджувати про наявність у р. Стрий щонайменше 27 видів риб, які належать до 8 родин (табл.). Серед них у наших зборах було виявлено 24 види. Варто зазначити, що у фондових матеріалах Зоологічного музею НАН України налічується всього 12 видів 3 р. Стрий, лише один з яких - верховка Leucaspius delineatus, у наших виловах не траплявся. Такі види, як білизна Aspius aspius i харіус Thymallus thymallus, були відмічені у виловах рибалок, причому білизна зустрічалась переважно в середній та нижній течії, а харіус - у верхній ділянці річки та її гірських притоках.

Табличя. Сучасний склад іхтіофауни річки Стрий

Table. Current composition of fish fauna in the Stryi River

\begin{tabular}{|c|c|c|c|c|c|}
\hline \multirow[b]{2}{*}{ № } & \multirow[b]{2}{*}{$\begin{array}{c}\text { Таксономічна одиниця / } \\
\text { Taxonomic unit }\end{array}$} & \multirow{2}{*}{$\begin{array}{c}\text { 3M } \\
\text { HAHY / } \\
\text { ZM } \\
\text { NASU }\end{array}$} & \multirow{2}{*}{$\begin{array}{c}\text { ІГБ } \\
2017- \\
2019 \text { / } \\
\text { ІНВ } \\
2017- \\
2019 \\
\end{array}$} & \multicolumn{2}{|c|}{$\begin{array}{l}\text { Охоронний статус / } \\
\text { Conservation status }\end{array}$} \\
\hline & & & & $\begin{array}{l}\text { Червона книга } \\
\text { України / Red } \\
\text { Book of Ukraine }\end{array}$ & $\begin{array}{c}\text { Бернська } \\
\text { конвенція / } \\
\text { Berne } \\
\text { Convention }\end{array}$ \\
\hline \multicolumn{6}{|c|}{ Cурrinidae - коропові / carps } \\
\hline 1 & Leuciscus leuciscus (Linnaeus, 1758) & - & + & $\begin{array}{l}\text { вразливий / } \\
\text { vulnerable }\end{array}$ & \\
\hline 2 & Squalius cephalus (Linnaeus, 1758) & + & + & & \\
\hline 3 & Rutilus rutilus (Linnaeus, 1758) & - & + & & \\
\hline 4 & Chondrostoma nasus (Linnaeus, 1758) & - & + & & III \\
\hline 5 & Alburnoides rossicus (Berg, 1924) & + & + & $\begin{array}{l}\text { зникаючий / } \\
\text { endangered }\end{array}$ & \\
\hline 6 & Alburnus alburnus (Linnaeus, 1758) & + & + & & \\
\hline
\end{tabular}




\begin{tabular}{|c|c|c|c|c|c|}
\hline \multirow[b]{3}{*}{ № } & \multirow[b]{3}{*}{$\begin{array}{l}\text { Таксономічна одиниця / } \\
\text { Taxonomic unit }\end{array}$} & \multicolumn{4}{|c|}{ Продовження табл. / Continuation of the table. } \\
\hline & & \multirow{2}{*}{$\begin{array}{c}\text { 3M } \\
\text { HAHY / } \\
\text { ZM } \\
\text { NASU }\end{array}$} & \multirow{2}{*}{$\begin{array}{c}\text { ІГБ } \\
2017- \\
2019 \text { / } \\
\text { ІНВ } \\
2017- \\
2019 \\
\end{array}$} & \multicolumn{2}{|c|}{$\begin{array}{l}\text { Охоронний статус / } \\
\text { Conservation status }\end{array}$} \\
\hline & & & & $\begin{array}{c}\text { Червона книга } \\
\text { України / Red } \\
\text { Book of Ukraine }\end{array}$ & $\begin{array}{c}\text { Бернська } \\
\text { конвенція / } \\
\text { Berne } \\
\text { Convention }\end{array}$ \\
\hline 7 & Leucaspius delineatus (Heckel, 1843) & + & - & & III \\
\hline 8 & Phoxinus phoxinus (Linnaeus, 1758) & + & + & & \\
\hline 9 & Vimba vimba (Linnaeus, 1758) & - & + & & III \\
\hline 10 & Aspius aspius Linnaeus, 1758 & - & + & & III \\
\hline 11 & Rhodeus amarus (Bloch, 1782) & - & + & & III \\
\hline 12 & $\begin{array}{l}\text { Pseudorasbora parva (Temminck \& } \\
\text { Schlegel, 1846) }\end{array}$ & - & + & & \\
\hline 13 & Gobio sarmaticus (Berg, 1949) & + & + & & \\
\hline 14 & Romanogobio kesslerii (Dybowski, 1862) & + & + & $\begin{array}{l}\text { вразливий / } \\
\text { vulnerable }\end{array}$ & III \\
\hline 15 & Barbus barbus (Linnaeus, 1758) & - & + & $\begin{array}{l}\text { вразливий / } \\
\text { vulnerable }\end{array}$ & \\
\hline 16 & $\begin{array}{l}\text { Barbus carpathicus (Kotlík, } \\
\text { Tsigenopoulos, Ráb \& Berrebi, 2002) }\end{array}$ & + & + & $\begin{array}{l}\text { вразливий / } \\
\text { vulnerable }\end{array}$ & III \\
\hline 17 & Carassius gibelio (Bloch, 1782) & + & + & & \\
\hline \multicolumn{6}{|c|}{ Cobitidae - в'юнові / loaches } \\
\hline 18 & Sabanejewia baltica (Witkowskii, 1994) & + & + & & III \\
\hline 19 & Barbatula barbatula (Linnaeus, 1758) & + & + & & \\
\hline \multicolumn{6}{|c|}{ Salmonidae - лососеві / salmonids } \\
\hline 20 & Thymallus thymallus (Linnaeus, 1758) & - & + & $\begin{array}{l}\text { вразливий / } \\
\text { vulnerable }\end{array}$ & III \\
\hline 21 & Salmo trutta (Linnaeus, 1758) & - & + & & \\
\hline \multicolumn{6}{|c|}{ Esocidae - щукові / pikes } \\
\hline 22 & Esox lucius (Linnaeus, 1758) & - & + & & \\
\hline \multicolumn{6}{|c|}{ Cottidae - рогаткові / bullheads } \\
\hline 23 & Cottus gobio (Linnaeus, 1758) & + & + & & \\
\hline \multicolumn{6}{|c|}{ Percidae-окуневі / perches } \\
\hline 24 & Perca fluviatilis (Linnaeus, 1758) & - & + & & \\
\hline \multicolumn{6}{|c|}{ Odontobutidae - головешкові / freshwater sleepers } \\
\hline 25 & Perccottus glenii (Dybowski, 1877) & - & + & & \\
\hline \multicolumn{6}{|c|}{ Gobiidae - бичкові / gobies } \\
\hline 26 & Neogobius fluviatilis (Pallas, 1814) & - & + & & III \\
\hline 27 & Babka gymnotrachelus (Kessler, 1857) & - & + & & \\
\hline Bcbo & о видів: / Total number of species: & 12 & 26 & 6 & 10 \\
\hline
\end{tabular}

Примітка: ЗМ НАНУ - дані фондових матеріалів Зоологічного музею НАН України; ІГБ 2017-2019 - дані польових досліджень Інституту гідробіології НАН України, III - підлягає охороні, згідно з Додатком III Бернської конвенції.

Annotation: ZM NASU - data of stock materials of Zoological Museum of the National Academy of Sciences of Ukraine; IHB 2017-2019 - field research data of Institute of Hydrobiology NAS of Ukraine, III - subject to protection according to Annex III of the Berne Convention. 
Охоронний статус в р. Стрий мають 13 видів риб, що складає практично половину зареєстрованих видів (48\%). 3 них 6 занесені до Червоної книги України [9], 10 - до Додатка ІІІ Бернської Конвенції [10].

Розглянемо далі наші знахідки, особливості розподілу та характеристику раритетних та мігруючих видів, що вкрай важливо у зв'язку 3 планами інтенсивного зарегулювання карпатських річок. Перш за все, слід зазначити види, занесені до Червоної книги України: ялець звичайний Leuciscus leuciscus, бистрянка російська Alburnoides rossicus, білоперий пічкур дністровський Romanogobio kesslerii, марена звичайна Barbus barbus, марена карпатська Barbus carpathicus, харіус європейський Thymallus thymallus. Не меншої уваги вартує низка видів, які не належать до тих, що охороняються в Україні, але досить вимогливі до нерестового субстрату, кисневого режиму та чутливі до будь-якого людського втручання у гідрологічний режим річки: головень європейський Squalius cephalus, підуст звичайний Chondrostoma nasus, рибець звичайний Vimba vimba, лосось-кумжа (форель) Salmo trutta. Слід зазначити, що любительський лов рибця і форелі заборонено правилами любительського і спортивного рибальства України, незважаючи на відсутність їх у Червоній книзі [11]. Більшість вказаних видів здійснюють нерестові міграції різної протяжності. Нижче наведено характеристику охоронюваних та найбільш чутливих видів, та тих, що охороняються, які мешкають у річці Стрий (види подано у систематичному порядку).

Ялець звичайний Leuciscus leuciscus L. під час наших досліджень траплявся досить рідко. Поодинокими особинами ловився в осінній період в околицях населених пунктів Ісаї, Довге, Підгірці, Крушельниця, Розгірче, а також поблизу гирлових ділянках приток Рибник та Східниця. Піймані екземпляри мали довжину від 52 до 110 мм і найбільшу висоту тіла 10,5-26,0 мм. Розмноження у р. Стрий відбувається 3 кінця березня, при прогріванні води до $5-6^{\circ} \mathrm{C}$, до початку, а іноді й до кінця травня. Ікра донна, клейка, відкладається у місцях зі швидкою течією на різноманітні донні предмети, зокрема і на рослинність. Причиною падіння чисельності є зникнення типових біотопів внаслідок змін гідрологічного, хімічного, біологічного режимів водойм, викликаних гідротехнічним будівництвом та забрудненням води, а також надмірний вилов [7, 9]. Міграційна поведінка яльця в річках України практично не вивчена, але $\epsilon$ окремі дані з інших країн. Наприклад, в Англії за допомогою радіоміток було встановлено, що ялець досить активно мігрує, долаючи багато кілометрів як вгору, так і вниз за течією [12]. А в одній з річок Чехії впродовж квітня-травня спостерігали його підйом по рибоходу драбинчастого типу [13]. Тому цілком ймовірними є такі міграції яльця i в р. Стрий.

Головень європейський Squalius cephalus L. зустрічався практично скрізь, за винятком «форелевих» ділянок річки Рибник та ії притоки Зубриці. Довжина упійманих особин складала 36-145 мм, найбільша висота - 7,9-39,0 мм. Крім того, його личинки ( $l=8,0-8,5$ мм) постійно були присутні в іхтіопланктоні, зібраному мальковим сачком та ікорною сіткою в літній період. Згідно з нашими спостереженнями та даними місцевих рибалок, розмноження головня у Стрию відбувається з квітня по червень у місцях з піщано-гальковим чи кам'янистим грунтом, здебільшого недалеко від берега, на глибині до 0,5 м. Традиційно головня вважають досить осілою рибою, але останні дослідження показали, що, 
піднімаючись до нерестовищ зі сприятливим субстратом та кисневим режимом, він може долати відстань до 13 км [14]. Хоча головень є однією 3 найчисленніших риб середньої та нижньої течії практично всіх гірських річок України, він дуже чутливий до зміни їхнього гідрологічного режиму. Наприклад, у Дністровському і Дубосарському водосховищах Дністра головень, який переважав в іхтіофауні до зарегулювання, тепер практично повністю заміщений пліткою Rutilus rutilus [15].

Підуст звичайний Chondrostoma nasus L. у наших виловах був відмічений поблизу сіл Крушельниця, Довге і Рибник. Крім того, він зареєстрований у виловах рибалок-любителів в районі м. Жидачів. Довжина риб у наших зборах коливалась в межах 50-57 мм, у виловах рибалок - до 240 мм, найбільша висота тіла складала 11,5-60,0 мм. Нерест у Стрию починається в середині-кінці квітня при температурі води $7-8^{\circ} \mathrm{C}$; пік розмноження припадає на травень при температурі $10-13^{\circ} \mathrm{C}$, закінчується нерест в кінці травня - на початку червня при $16-20^{\circ} \mathrm{C}$. Перед нерестом риби збираються у великі зграї, при цьому плідники знатні підніматись до місць нересту із Дністра на десятки кілометрів. Ікра клейка, відкладається за один раз на ділянках з гальково-кам'янистим або гальковопіщаним грунтом на глибині $0,2-1,5$ м за швидкості течії 0,3-1,5 м/с [16]. Чисельність підуста у багатьох річках України зараз помітно знизилась [7].

Бистрянка російська Alburnoides rossicus Berg зустрічалась практично на всіх обстежених ділянках, що свідчить про сприятливі для неї умови в р. Стрий на даний час. Довжина тіла пійманих особин складала 37-48 мм, висота - 8,1-13,0 мм. Крім того, iі личинки $(l=8,5-9,5$ мм) завжди були присутні у пробах руслового іхтіопланктону, що вказує на успішне відтворення виду. Розмноження в Стрию триває з середини травня до кінця червня. Ікру відкладає декількома порціями на мілководних ділянках зі швидкою течією і твердим піщаним, гальковим або кам'янистим грунтом [7]. 3 кінця 1970-х рр. постійно скорочуються його ареал і чисельність. Причиною зниження чисельності є зникнення типових біотопів у результаті зміни гідрологічного, хімічного, біологічного режимів водойм, спричинене насамперед випрямленням руслових ділянок, гідротехнічним будівництвом, а також забрудненням води [9].

Рибець Vimba vimba L. поодиноко траплявся в околицях м. Жидачів та c. Корчин. Довжина особин складала 90-110 мм, найбільша висота тіла - 24,630,4 мм. Нерест порційний, 3 квітня по липень. Під час нересту схильний до висхідних нерестових міграцій на значні відстані 3 Дністра у різні притоки, зокрема i в Стрий. Маючи клейку ікру, рибці зазвичай надають перевагу субстрату $з$ дрібного каміння, гравію, піску та коренів рослин [7]. У Стрию успішно нереститься на каменях у місцях 3 вираженою течією та невеликою глибиною. Окрім нижньої течії Дунаю, в Україні повсюдно скорочується чисельність цього виду, переважно в результаті зарегулювання стоку річок та знищення проточних ділянок.

Білизна європейська Aspius aspius L. в наших зборах не виявлена, але іноді траплялась у виловах рибалок, де реєструвались поодинокі особини довжиною 270-350 мм. Згідно $з$ даними опитувань, періодично виловлюються екземпляри значно більшого розміру. Розмноження у Стрию зазвичай починається одразу після скресання річки, з березня до кінця квітня - початку травня, за температуріи води близько $4-10^{\circ} \mathrm{C}$. Ікра клейка, відкладається за один раз на руслових ділянках у місцях зі швидкою течією і твердим кам'янистим або піщано-гальковим 
грунтом на глибині 1,0-1,5 м [7]. Здійснює висхідні нерестові міграції для пошуку сприятливого нерестового субстрату, необхідної проточності та аерації води, а молоді особини потім скочуються до місць нагулу [17]. Чисельність у річках України відносно невисока [7].

Білоперий пічкур дністровський Romanogobio kesslerii Dybowski знайдений нами тільки в одному екземплярі ( $l=55$ мм, $H=8,5$ мм) в місці впадіння Стрию в Дністер. Нереститься 3 другої половини травня-червня до липня i, можливо, до вересня [7]. Нечисленний вид в Україні, з 1980-х pp. трапляється поодинокими екземплярами в річках басейну Дунаю і Дністра. У зв'язку з недостатнім вивченням виду причини зміни його чисельності точно не відомі. Вірогідно, насамперед це забруднення водойм та зміна гідрологічного режиму. Для збереження популяцій необхідні заборона вилову, виявлення типових місць існування та встановлення в них заповідного режиму [9].

Марена звичайна Barbus barbus L. у р. Стрий на даний час може вважатись досить поширеним видом, оскільки зустрічалась на більшості досліджених ділянок. Розмір особин складав 29-57 мм, висота тіла - 5,3-12,5 мм. Надає перевагу глибоким (1,5-2,0 м і більше) ділянкам з кам'янистим, гальковим, рідше піщано-гравійним дном на русловій частині річки. Згідно 3 літературними даними, у Карпатах зазвичай населяє річки на висоті не більше 500 м над рівнем моря, хоча у Стрию нами була відмічена дещо вище - близько 550 м н.р.м., на ділянці річки між селами Завадівка і Лосинець Турківського району. Нерест порційний, зазвичай проходить вище за руслом від основних місць нагулу або в притоках на мілководних ділянках з гальковим або гравійним дном і помірною течією, а також на кам'янистих чи піщаних перекатах. У пошуках необхідного нерестового субстрату марена може мігрувати на відстань до 20 км [18]. Ікра слабо клейка. Початок нересту - за температури води $10-12^{\circ} \mathrm{C}$, розпал - при $15-16^{\circ} \mathrm{C}$ і завершення - при $21-22^{\circ} \mathrm{C}[7]$.

Марена карпатська Barbus carpathicus, - також досить поширений вид марен у р. Стрий, який траплявся на більшості досліджуваних ділянок переважно разом $з$ мареною звичайною. Це найменший за розмірами представник роду в Україні, максимальна довжина тіла якого становить 30 см і маса - до 300 г. У наших виловах був представлений особинами довжиною 92-105 мм і висотою тіла 18,4-22,2 мм. Надає перевагу неглибоким (до 1-1,5 м) ділянкам 3 кам'янистим, гальковим, рідше піщаним дном. Тримається в рукавах, рідше на руслових ділянках Стрия. Максимальна висота поширення марени карпатської у p. Стрий, за нашими даними, - близько 400 м н.р.м. (с. Корчин, Сколівський район). Розмноження проходить 3 початку травня до кінця червня, розпочинається при температурі води близько $11^{\circ} \mathrm{C}$, його розпал відбувався за $16,0-17,5^{\circ} \mathrm{C}$ і закінчення - за $18,2^{\circ} \mathrm{C}$ [7]. Нерест порційний, на мілководдях 3 кам'янисто-гальковим грунтом, при відносно помірній течії, як вище основних місць нагулу, так і в місцях нагулу.

Нами встановлено, що для ранніх личинок обох видів марен характерний пелагічний спосіб життя і покатна міграція, в результаті якої молоді особини можуть зноситись течією значно нижче місць нересту плідників, де умови для нагулу більш сприятливі [19]. Під час досліджень в районі с. Дуліби (вище м. Стрий) у червні личинки марен із жовтковим мішком, які щойно вийшли з ікри, фіксувались у русловому іхтіопланктоні в значній кількості, у нічний час 
сягаючи 55\% за чисельністю у виловах ікорної сітки. Закономірно, що знесена молодь через декілька років при досягненні статевої зрілості знову підніматиметься вгору за течією на нерест, замикаючи міграційний цикл.

Xapiyc європейський Thymallus thymallus L. у наших виловах не траплявся, але, згідно з аналізом літературних джерел, інформаційних повідомлень та звітів рибалок на спеціалізованих форумах, а також результатів опитування рибалок та місцевого населення, харіус достовірно реєструється в гірських притоках р. Стрий першого i другого порядку, зокрема у Опорі, Зубриці та Рибнику. Зрідка зустрічається і в самому руслі Стрия. Згідно зі свідченнями рибалок-любителів, на річці Зубриця, розміри харіуса сягають 30 см і більше. А у притоках Опору реєструються особини до 45 см завдовжки [3]. Нереститься 3 кінця березня, переважно у квітні-травні.

Лосось-кумжа (форель струмкова) Salmo trutta L. - нечисленний вид у р. Стрий. Мальки форелі $(l=23-32$ мм) ловились у травні нижче гирла р. Рибник, а також у самій притоці близько 1 км вище іiі впадіння у Стрий та у місці іії злиття 3 притокою Зубриця. Дорослі особини (максимальний розмір $l=290$ мм) реєструвались у виловах рибалок на верхній гірській ділянці (вище с. Ропавське), а також у притоках Рибник, Зубриця та у гірських притоках річки Опір. Як і в інших гірських річках Українських Карпат, у Стрию форель зазвичай нереститься 3 жовтня по грудень. Нерест проходить на мілководних ділянках з гальковим грунтом при температурі води $6,0-8,5^{\circ} \mathrm{C}$. До нерестовищ форель може мігрувати на значні відстані. Ікра донна, відкладається однією самицею у ямку на дні, яку вона після запліднення ікри закопує дрібними каменями і галькою [7].

Загалом в іхтіофауні р. Стрий переважають річкові види; типові літореофіли нерестяться на ділянках з доброю проточністю і піщаним, гравійним, гальковим або кам'янистим дном. На даний час практично по всій довжині річки Стрий створюються цілком сприятливі умови для відтворення таких риб: швидкість течії на досліджуваних ділянках коливалась від 0,6 до 2,5 м/с; в таких умовах субстрат переважно був кам'янистим, замуленість спостерігалась тільки у бічних рукавах та старицях. Потенційні нерестовища для вищезгаданих представників раритетної іхтіофауни та мігруючих риб були наявні практично вздовж усієї обстеженої ділянки Стрия. Для лососевих риб вкрай важливе значення становлять також i гірські притоки. В осінній період форель і харіус можуть заходити на нерест у такі притоки, які мають необхідний субстрат, проточність і температурний режим. Крім того, невеликі річки і холодноводні гірські струмки у період літньої спеки можуть слугувати схованками для лососевих риб, для яких температура вище $20^{\circ} \mathrm{C}$, цілком характерна для середньої і нижньої течії Стрия, є вкрай несприятливою. Стосовно коропових риб-мігрантів, у період водопілля малі притоки Стрия завдяки збільшенню водності, також будуть слугувати для них важливими нерестовищами.

Лімнофільні види в умовах гірської річки зустрічались досить рідко. На даний час серед них відмічено два інвазивні види: головешка ротань Perccottus glenii і амурський чебачок Pseudorasbora parva, які траплялись поодинокими особинами здебільшого у прируслових старицях і невеликих зарослих замулених рукавах зі сповільненою течією. Для виловлених Perccottus glenii лінійні розміри коливались в межах: $l=44-62$ мм, $H=11,2-17,5$ мм; для Pseudorasbora parva: $l=$ 43-81 мм, $H=10,5-20,4$ мм. Слід наголосити, що зарегулювання стоку річки 3 
наступною зміною гідрологічного режиму може призвести до підвищення чисельності вказаних видів-вселенців, що може мати негативні наслідки для аборигенної річкової іхтіофауни. Крім того, через порушення гідрологічного режиму річки в результаті гідротехнічного будівництва річкові види можуть скоротити чисельність і поступово витіснитись озерними видами. При зарегулюванні стоку відбувається сповільнення течії, замулення нерестовищ, заростання русла, внаслідок чого такі види отримують значну перевагу над реофілами і поступово виходять на домінантні позиції в іхтіоценозах.

\section{ВИСНОВКИ ТА ПЕРСПЕКТИВИ ПОДАЛЬШОГО РОЗВИТКУ}

Одержані дані дають підстави стверджувати, що річка Стрий характеризується значним видовим багатством та різноманіттям іхтіофауни, слугує середовищем існування для низки раритетних риб, а також чутливих річкових видів. Аналіз отриманих нами даних та літературних свідчень вказує на те, що у р. Стрий, найбільшій притоці Дністра, мешкає щонайменше 27 видів риб із 8 родин. Основу іхтіофауни складають літореофільні аборигенні види; поширення лімнофільних, а також інвазивних видів на даний час обмежене. Созологічний аналіз вказує на високий ступінь раритетності іхтіофауни: 6 видів занесено до Червоної книги України, 10 - до списків Бернської Конвенції. Більшість реофільних видів у р. Стрий здійснюють досить далекі міграції як у межах головного русла, так і його приток. Для збереження аборигенної річкової іхтіофауни, зокрема раритетних видів риб, необхідно вкрай обережно i обгрунтовано підходити до будь-якої господарської діяльності в межах річкового басейну, яка порушує природний гідрологічний режим чи призводить до забруднення води, а на окремих ділянках - взагалі забороняти таку діяльність. Подальші дослідження в різні сезони року дадуть змогу отримати більш повну інформацію про іхтіофауну, визначити місця нересту та нагулу риб, і цілком імовірно, розширити список видів.

\section{ЛІТЕРАТУРА}

1. Географічна енциклопедія України : в 3-х т. / відп. ред. Маринич О. М. Київ : Українська Радянська Енциклопедія ім. М. П. Бажана, 1993. Т. 3. 480 с.

2. Річка Стрий: інформація не тільки для рибалок. URL : https://taor.com.ua/library/47_richka-stryy-informacija-ne-tilky-dlja-rybalok (дата звернення : 16.11.2018).

3. Львівський клуб активного відпочинку: список форумів. URL : http://www.active.lviv.ua/topic-t381-15.html (дата звернення : 12.06.2019).

4. Каталог коллекций Зоологического музея ННПМ НАН Украины / Мовчан Ю. В. и др. Киев : Зоомузей ННПМ НАН Украины, 2003. 342 с.

5. Правдин И. Ф. Руководство по изучению рыб. Москва : Пищ. пром-сть, 1966. $376 \mathrm{c.}$

6. Маркевич О. П., Короткий І. І. Визначник прісноводних риб УРСР. Київ : Радянська школа, 1954. 208 с.

7. Мовчан Ю. В. Риби України (визначник-довідник). Київ : Золоті ворота, 2011. $444 \mathrm{c}$.

8. Коблицкая А. Ф. Определитель молоди пресноводных рыб. Москва : Легкая и пищевая пром-сть, 1981. 208 с. 
9. Червона книга України. 2009 (III вид.). URL : http://redbook-ua.org (дата звернення : 9.09.2019).

10. Convention on the Conservation of European Wildlife and Natural Habitats. URL : https://www.coe.int/en/web/conventions/full-list/-/conventions/treaty/104 (дата звернення : 15.07.2019).

11. Про затвердження Правил любительського і спортивного рибальства та Інструкції про порядок обчислення та внесення платежів за спеціальне використання водних живих ресурсів при здійсненні любительського і спортивного рибальства. Наказ № 19 від 15.02.99. URL : https://zakon.rada.gov.ua/laws/show/z0269-99 (дата звернення : 15.07.2019).

12. Clough S., Beaumont W. R. C. Use of miniature radio-transmitters to track the movements of dace, Leuciscus leuciscus (L.) in the River Frome, Dorset // Advances in Invertebrates and Fish Telemetry / eds. Lagardère J.-P., Anras M.L. B., Claireaux G. Dordrecht : Springer, 1998. P. 89-97 (Hydrobiologia ; vol. 371/372).

13. Lucas M. C., Baras E. Migration of Freshwater Fishes. Ames : Iowa State Press, $2001.420 \mathrm{p}$.

14. Spawning migrations of the chub in the River Spree, Germany / Fredrich F. et al. // Journal of Fish Biology. 2003. Vol. 63. P. 710-723.

15. Худий О. І. Зміни в іхтіофауні різних ділянок Дністра під впливом антропогенних чинників // Гидробиол. журн. 2002. Т. 38, № 6. С. 33-39.

16. Povz M. Migrations of the nase carps (Chondrostoma nasus L. 1758) in the River Sava // Journal of Aquatic Production (Ljubljana). 1988. № 2. P. 149-163.

17. Lelek A. The Freshwater Fishes of Europe. Vol. 9 : Threatened Fishes of Europe. Wiesbaden : Aula Verlag, 1987. 343 p.

18. Lucas M. C., Batley E. Seasonal Movements and Behaviour of Adult Barbel Barbus barbus, a Riverine Cyprinid Fish: Implications for River Management // Journal of Applied Ecology. 1996. Vol. 33, № 6. P. 1345-1358.

19. Абрам'юк I. І. Скочування ікри та личинок деяких видів риб у р. Ріка (басейн Тиси) // Сучасна гідроекологія: місце наукових досліджень у вирішенні актуальних проблем : IV наук-практ. конф. для молодих вчених, присвячена 100-річчю Національної академії наук України : матер. Київ : Логос, 2017. С. $7-8$.

\section{REFERENCES}

1. Marynych, O. M. (Ed.). (1993). Heohrafichna entsyklopediia Ukrainy (Vol. 1-3; Vol. 3). Kyiv: Ukrainska Radianska Entsyklopediia im. M. P. Bazhana.

2. Richka Stryi: informatsiia ne tilky dlia rybalok. taor.com.ua. Retrieved from https://taor.com.ua/library/47_richka-stryy-informacija-ne-tilky-dlja-rybalok.

3. Lvivskyi klub aktyvnoho vidpochynku: spysok forumiv. active.lviv.ua. Retrieved from http://www.active.lviv.ua/topic-t381-15.html.

4. Movchan, Yu. V., Manilo, L. G., \& Smirnov, A. I., et al. (2003). Katalog kollektsiy Zoologicheskogo muzeya NNPM NAN Ukrainy. Kiev: Zoomuzey NNPM NAN Ukrainy.

5. Pravdin, I. F. (1966). Rukovodstvo po izucheniyu ryb. Moskva: Pishch. prom-st'.

6. Markevych, O. P., \& Korotkyi, I. I. (1954). Vyznachnyk Prisnovodnykh ryb URSR. Kyiv: Radianska shkola. 
7. Movchan, Yu. V. (2011). Ryby Ukrainy (vyznachnyk-dovidnyk). Kyiv: Zoloti vorota.

8. Koblitskaya, A. F. (1981). Opredelitel' molodi presnovodnykh ryb. Moskva: Legkaya i pishchevaya prom-st'.

9. Chervona knyha Ukrainy. 2009 (III edn.). redbook-ua.org. Retrieved from http://redbook-ua.org.

10. Convention on the Conservation of European Wildlife and Natural Habitats. coe.int. Retrieved from https://www.coe.int/en/web/conventions/full-list//conventions/treaty/104.

11. Pro zatverdzhennia Pravyl liubytelskoho i sportyvnoho rybalstva ta Instruktsii pro poriadok obchyslennia ta vnesennia platezhiv za spetsialne vykorystannia vodnykh zhyvykh resursiv pry zdiisnenni liubytelskoho i sportyvnoho rybalstva. Nakaz $\mathrm{N} \quad 19$ vid 15.02.99. zakon.rada.gov.ua. Retrieved from https://zakon.rada.gov.ua/laws/show/z0269-99.

12. Clough, S., \& Beaumont, W. R. C. (1998). Use of miniature radio-transmitters to track the movements of dace, Leuciscus leuciscus (L.) in the River Frome, Dorset. Advances in Invertebrates and Fish Telemetry. Hydrobiologia 371/372. Dordrecht: Springer, 89-97.

13. Lucas, M. C., \& Baras, E. (2001). Migration of Freshwater Fishes. Ames: Iowa State Press.

14. Fredrich, F., Ohmann, S., Curio, B., \& Kirschbau, F. (2003). Spawning migrations of the chub in the River Spree, Germany. Journal of Fish Biology, 63, 710-723.

15. Khudyi, O. I. (2002). Zminy v ikhtiofauni riznykh dilianok Dnistra pid vplyvom antropohennykh chynnykiv. Gidrobiol. Zhurn, 38(6), 33-39.

16. Povz, M. (1988). Migrations of the nase carps (Chondrostoma nasus L. 1758) in the River Sava. Journal of Aquatic Production (Ljubljana), 2, 149-163.

17. Lelek, A. (1987). The Freshwater Fishes of Europe. Vol. 9, Threatened Fishes of Europe. Wiesbaden: Aula Verlag.

18. Lucas, M. C., \& Batley, E. (1996). Seasonal Movements and Behaviour of Adult Barbel Barbus barbus, a Riverine Cyprinid Fish: Implications for River Management. Journal of Applied Ecology, 33(6), 1345-1358.

19. Abramiuk, I. I. (2017). Skochuvannia ikry ta lychynok deiakykh vydiv ryb u r. Rika (basein Tysy). Suchasna hidroekolohiia: mistse naukovykh doslidzhen u vyrishenni aktualnykh problem: IV nauk.-prakt. konf. dlia molodykh vchenykh, prysviachena 100-richchiu Natsionalnoi akademii nauk Ukrainy. Kyiv: Lohos, 7-8. 


\section{DENSITY OF LOCATION OF THE EASTERN FRESHWATER SHRIMPS (MACROBRANCHIUM NIPPONENSE DE HAAN, 1849) IN THE LOWER RIVER BASIN DNISTER}

\section{P. Shekk, shekk@ukr.net, Odessa State Environmental University, Odessa Yu. Astafurov, astafurov.yu@ukr.net, Odessa State Environmental University, Odessa}

Purpose. To investigate the distribution of Macrobrachium nipponense in the Dniester river basin in the south of Ukraine. To assess their density and diurnal fluctuations and determine their sex ratios in different waters.

Methodology. Shrimps were caught using crayfish traps of original design with a length of 50-

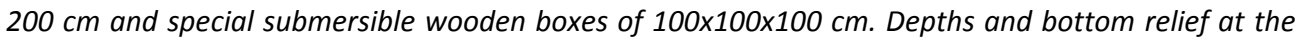
study sites were determined using a Garmin EchoMAP CHIRP 72sv. The location was established using a GPS unit Garmin gpsmap 78s and Google Maps 2D. The sample size was 4687 individuals, 88 locations of shrimp aggragations were detected. The diurnal population dynamics was studied at 7 sites. Sex and sex ratio of sampled shrimps where determined using a standard biological analysis.

Findings. The analysis of litertures sources showed the pathways of the spread of $M$. nipponense across the territory of the republics of the USSR and the history of its acclimatization in the Dniester River. The currents shrimp stock density and their sex ratios in different water bodis of the lower Dniester were determined. The diurnal dynamics of changes in shrimp populations was studied at different sites in the Dniester and Kuchurgan lagoons. It was found that the local populations of shrimp from different waters differ significantly in terms of their numbers and sex ratios. The circadian dynamics of shrimp population density in the Dniester and Kuchurgan lagoons had a similar character but differed in absolute numbers.

Originality. The distribution of $M$. nipponense in the lower reaches of the Dniester was studied for the first time. The abundance of this shrimp in different waters and their sex ratio were established. The circadian dynamics of population changes in the Dniester and Kuchurgan estuaries was studied.

Practical value. The results of the study allowed obtaining an objective biological-geographical characteristic of M. nipponense in the conditions of the Lower Dniester basin. The obtained results can be used to assess the state of the natural population of M. nipponense in the lower Dniester and to determine the prospects of its use as an object of domestic fish farming and aquaculture.

Key words: Shrimp, M. nipponense, Lower Dniester, introduction, natural population, density, sex differences.

\section{ИССЛЕДОВАНИЯ ПЛОТНОСТИ СКОПЛЕНИЙ ВОСТОЧНОЙ ПРЕСНОВОДНОЙ КРЕВЕТКИ (MACROBRANCHIUM NIPPONENSE DE HAAN, 1849) В БАССЕЙНЕ НИЖНЕГО ДНЕСТРА}

П. В. Шекк, shekk@ukr.net, Одесский государственный экологический университет, г. Одесса

Ю. А. Астафуров, astafurov.yu@ukr.net, Одесский государственный экологический университет, г. Одесса

C P. Shekk, Yu. Astafurov, 2020 
Цель работы. Исследовать распространение Macrobrachium nipponense на территории юга Украины в бассейне нижнего Днестра. Оценить плотность креветки и ее суточные колебания, установить соотношение ото к $о$ о различных акваториях.

Методика. Для отлова креветок использовали ловушки типа раколовки длиной от 50200 см оригинальной конструкции и специальные погружные деревянные короба размером $100 \times 100 \times 100$ см. Глубины и рельеф дна в местах проведения исследований определяли $c$ помощью эхолота Garmin EchoMAP CHIRP 72sv. Локацию устанавливали с помощью спутникового GPS навигатора garmin gpsmap 78s u google maps 2d. Объем выборки составила 4687 экз. креветок, установлено 88 локаций скоплений креветок. Суточную динамику численности изучали на 7 стационарных станциях. При проведении стандартного биологического анализа у креветок определяли: пол, и соотношение оㅇк $\$$.

Результаты. На основе анализа литературных источников установлены пути распространения креветок М. пірропеnse на территории республик СССР и историю акклиматизации ее в р. Днестр. Определена современная плотность креветки и соотношение полов в различных акваториях нижнего Днестра. На стационарных станциях в Днестровском и Кучурганском лиманах исследовалась суточная динамика изменений численности креветки. Установлено, что по показателям численности и соотношения о“б" фо локальные популяции креветки с разных акваторий значительно различаются. Церкадная динамика плотности популяций креветки в Днестровском и Кучурганском лиманах имела сходный характер но отличалась по абсолютным показателям.

Научная новизна. Впервые исследовано распространение интродуценты - креветки М. nipponen в низовьях Днестра. Установлено численность креветки в различных акваториях и соотношение от" и фо. Иследована циркадная динамика изменений численности в Днестровском и Кучурганском лиманах.

Практическая значимость. Результаты исследований позволили дать объективную эколого-биологическую характеристику M. nipponense в условиях бассейна нижнего Днестра. Полученные результаты могут быть использованы для оценки состояния природной популяции М. nipponense нижнего Днестра и определения перспектив ее использовании в качестве объекта отечественного рыбоводства и аквакультуры.

Ключевые слова: Креветка, М. nipponense, нижний Днестр, интродукция, естественная популяция, плотность, половое соотношение.

\title{
ДОСЛІДЖЕННЯ ЩІЛЬНОСТЕЙ СКУПЧЕННЯ СХІДНОЇ ПРІСНОВОДНОÏ КРЕВЕТКИ (MACROBRANCHIUM NIPPONENSE DE HAAN, 1849) В БАСЕЙНІ НИЖНЬОГО ДНІСТРА
}

\author{
П. В. Шекк, shekk@ukr.net, Одеський державний екологічний університет, \\ м. Одеса \\ Ю. О. Астафуров, astafurov.yu@ukr.net, Одеський державний екологічний \\ університет, м. Одеса
}

Mema. Дослідити поширення Macrobrachium nipponense на території півдня України у басейні нижнього Дністра. Оцінити щільність креветки та ії добові коливання, встановити співідношення о“о"до о० в різних акваторіях.

Методика. Для вилову креветок використовували пастки типу раколовки довжиною від 50-200 см оригінальної конструкції та спеціальні погружні дерев'яні короби розміром 100×100×100 см. Глибини та рельєф дна в місцях проведення досліджень визначали за допомогою ехолота Garmin EchoMAP CHIRP 72sv. Локацію встановлювали за допомогою супутникового GPS навігатора garmin gpsmap 78s ma google maps 2 . Обсяг вибірки становил 4687 екз. креветки, встановлено 88 локачій скупчення креветок. Добову динаміку 
чисельності вивчали на 7 стаціонарних станціях. При проведенні стандартного біологічного аналізу у креветок визначали: стать, та співідношення о о" до $q 9$.

Результати. На основі аналізу літературних джерел встановлені иляхи розповсюдження креветок М. пірроnense на теріторії республік колишенього СРСР, історія акліматизації ї̈ в р. Дністер.

Визначена сучасна щільність креветки та співвідношення статей в різних акваторіях нижнього Дністра. На стаціонарних станціях у Дністровському та Кучурганському лиманах досліджувалась добова динаміка змін чисельності креветки. Встановлено, що за показниками чисельності та співвідношення о“о̆ $і$ оЯ локальні популяції креветки з різних акваторій значно різняться. Церкадна динаміка щільності популяцій креветки у Дністровському та Кучурганському лиманах мала схожий характер але відрізнялась за абсолютними показниками.

Наукова новизна. Вперше досліджено розповсюдження інтродуценти - креветки М. nipponen в пониззі Дністра. Встановлено чисельність креветки в різних акваторіях та співвідношення о“o"i о․ Виявлена циркадна динаміка змін чисельності у Дністровському та Кучурганському лиманах.

Практична значимість. Результати досліджень дозволили дати об'єктивну екологобіологічну характеристику М. пірропепsе в умовах басейну нижнього Дністра. Отримані результати можуть бути використані для оцінки стану природної популяції M. пірроnense нижнього Дністра та визначення перспектив ії використання як об'єкту вітчизняного рибництва та аквакультури.

Ключові слова: Креветка, М. пірропепsе, нижній Дністер, інтродукція, природна популяція, щільність, статеве співвідношення.

\section{PROBLEM STATEMENT AND ANALYSIS OF LATEST RESEARCH AND PUBLICATIONS}

Since the beginning of the twentieth century the problem of biological invasions of alien species has become more acute, and there has been a significant increase in alien species in areas quite far from their natural ranges. This phenomenon is global and significantly affected aquatic ecosystems, including those that belong to the Black Sea catchment, where the number of new species of flora and fauna has increased in recent decades $[7,12]$.

In autumn 2013, several specimens of M. nipponense were caught in a crayfish trap in the Dniester River near Tiraspol by a student of the Faculty of Geography of the Taras Shevchenko Transnistrian State University. Thus, 27 years after the introduction of this species into the Kuchurgan reservoir, it was able to: acclimatize in the reservoir, adapt to low temperatures, establish a stable natural population capable of effective reproduction, penetrate into the Turunchuk Strait where it spread upstream, penetrated into the Dniester River reaching Tiraspol [12].

According to Google Maps, the distance covered by this shrimp from the Kuchurgan Reservoir to Tiraspol was about $70 \mathrm{~km}$ or $2.5 \mathrm{~km}$ per year $[12,15]$.

In July and August 2013, Odessa scientists Stepanko N. and Gubanov V. identified shrimp M. nipponens in the Dniester lagoon during the sampling of benthic fauna in the waters of the Dniester estuary near the village Nikolaevka. The shrimps sampled were two females with eggs. Sampling was carried out with a net with a mesh size of $10 \mathrm{~mm}$ on the coastal area with muddy bottom. Later, in the northern part of the Karagol Bay, rangers of the State Protection Service of the Lower Dniester National Nature Park 
found another 6 specimens in poachers' traps (mesh size of 18-20 mm). Forty eight individuals of $M$. nipponens of different age groups including one egg-laden female were caught in a fish pond near the village Mayaki at a depth of $0.5 \mathrm{~m}$ [11].

Interviewing of local fishermen confirmed the presence of M. nipponens in the Dniester and Turunchuk rivers [11, 12, 14].

In 2016, Head of the Department of Aquatic Bioresources and Aquaculture, Odessa State Ecological University Shekk P. and junior research scientist (graduate student) of the Department of Aquatic Bioresources and Aquaculture of Odessa State Ecological University Astafurov Yu. initiated complex works on the study of the distribution of $M$. nipponens in the lower reaches of the Dniester River $[14,15]$.

The area of the lower Dniester as a whole is interesting by very drastic and rapid changes in the environmental conditions for a short period of time starting from 1986. Thus, the interaction of "biogeography" with the practice regarding the problem of biotic invasions is necessary $[11,14]$.

The importance of the topic is enhanced by the fact that works in this area is actively carried out in the United States, Britain, Sweden, France, Australia and other countries. In Ukraine, such studies have not been conducted systematically, and the materials available in the literature are fragmentary and incomplete and require analysis and generalization. This is necessary to initiate more detailed studies in this direction [5, $13]$.

\section{SELECTION OF UNRESOLVED PARTS GENERAL PROBLEM. THE PURPOSE OF THE WORK}

To date, the study of the distribution of M. nipponens in the lower Dniester has not been conducted. There are only fragmentary data on the occurrence of individual shrimp in different waters. The formation of M. nipponens aggregations, their density and sex ratio in the Dniester river basin has also not been studied.

\section{MATERIALS AND METHODS}

The study was conducted from 2016-2019 on coastal sites of the Dniester River in lagoons and lakes. M. nipponens were caught with crayfish traps of original design with a length of 50-200 cm and special submersible wooden boxes of 100x100x100 cm. Depths and relief of the bottom at the sampling sites were determined using a Garmin EchoMAP CHIRP 72sv. The standard biological analysis of shrimps included the determination of their sex and sex ratio. In total, 4687 specimens were analyzed. shrimp, 88 locations of shrimp aggregations were established. Monthly continuous observations were performed at 7 sites.

Species identification of shrimps was performed using the appropriate identification keys $[2,10]$. The location was recorded using a GPS navigator Garmin Gpsmap 78s. Statistical data processing was performed in Microsoft Excel.

\section{RESEARCH RESULTS AND DISCUSSION}

M. nipponense were found in brackish waters of estuaries, lagoons, along sea coasts, as well as at great distances from the sea: rivers with large amounts of aquatic vegetation with sandy or muddy bottoms $[6,16,17,18]$. 
The native range of $M$. nipponense covers China, Japan, Korea, Vietnam, Myanmar and Taiwan. As a promising object of aquaculture, it was introduced into the water bodies of Singapore, Philippines, USA, Israel, Iraq, Iran, India, the republics of the former USSR (Russia, Belarus, Moldova, Kazakhstan, Tajikistan) and other countries [1, 4 6, 8, 19, 20, 21, 22] (Fig. 1).

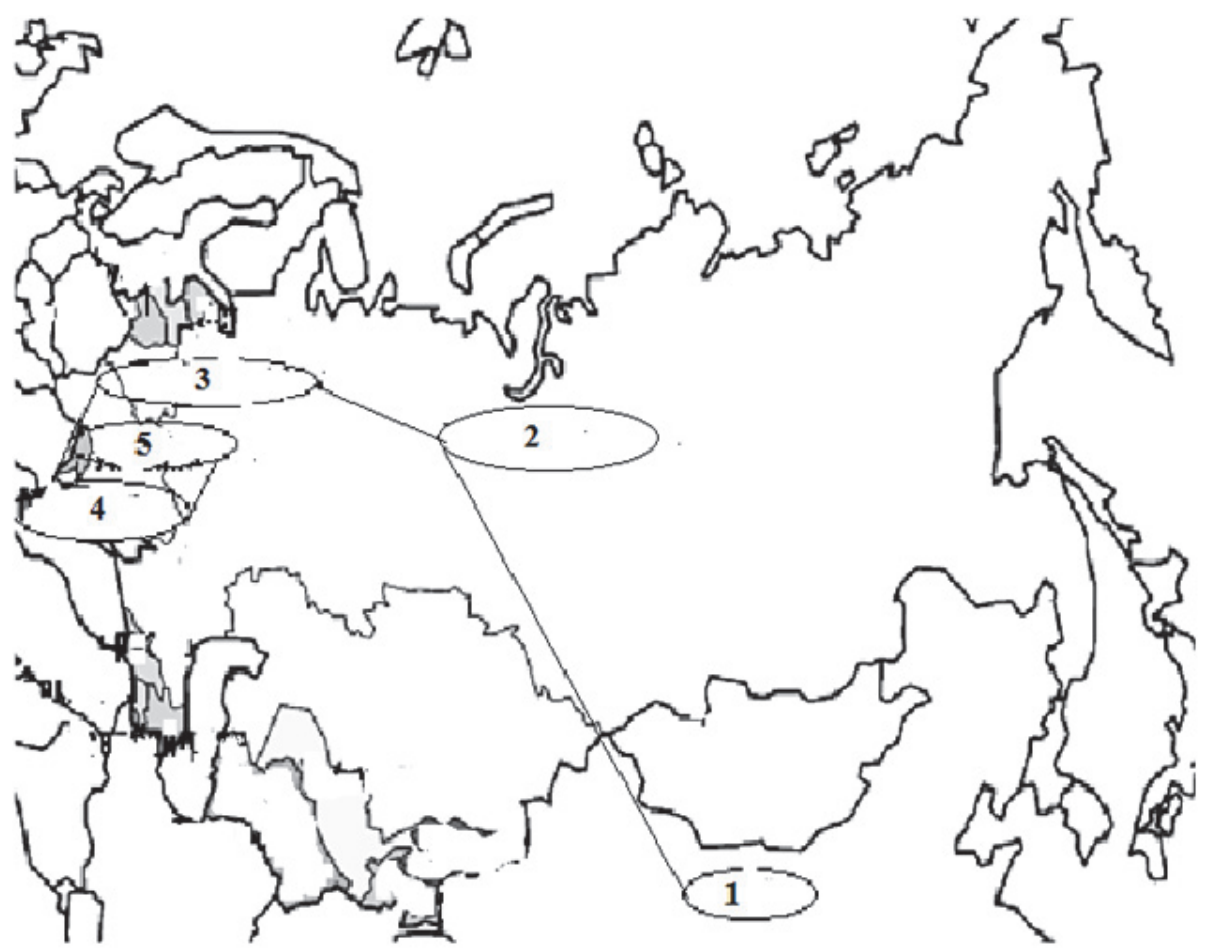

Fig. 1. Introductory shrimp scheme M. nipponense from China - 1 to Russia 2, Belarus - 3, Pridnistrov'ya (Moldova) - 4 and Ukraine - 5

M. nipponense was introduced into the Kuchurgan Reservoir from the Berezovskaya GRES reservoir. The stocking density of $M$. nipponense in the reservoir in 1986 was about 2 ind./ha and this was enough to obtain a positive effect of acclimatization [3].

Since the end of 1987, the population abundance in the reservoir was assessed as 0.6 million individuals, and it increased to almost 1.5 million individuals in 1988. Due to favorable ecological conditions, the growth rate of this shrimp in the Kuchurgan Reservoir was higher than in the parent reservoirs of Southeast Asia and the cooling reservoirs of the Berezovskaya GRES [3, 7, 9, 12].

The population of freshwater shrimp in the Kuchurgan reservoir was dominated by males. The shrimp population in the reservoir showed high potential reproductive capacity (fertility), which also contributed to the successful naturalization of the species $[3,7,11,12]$. 


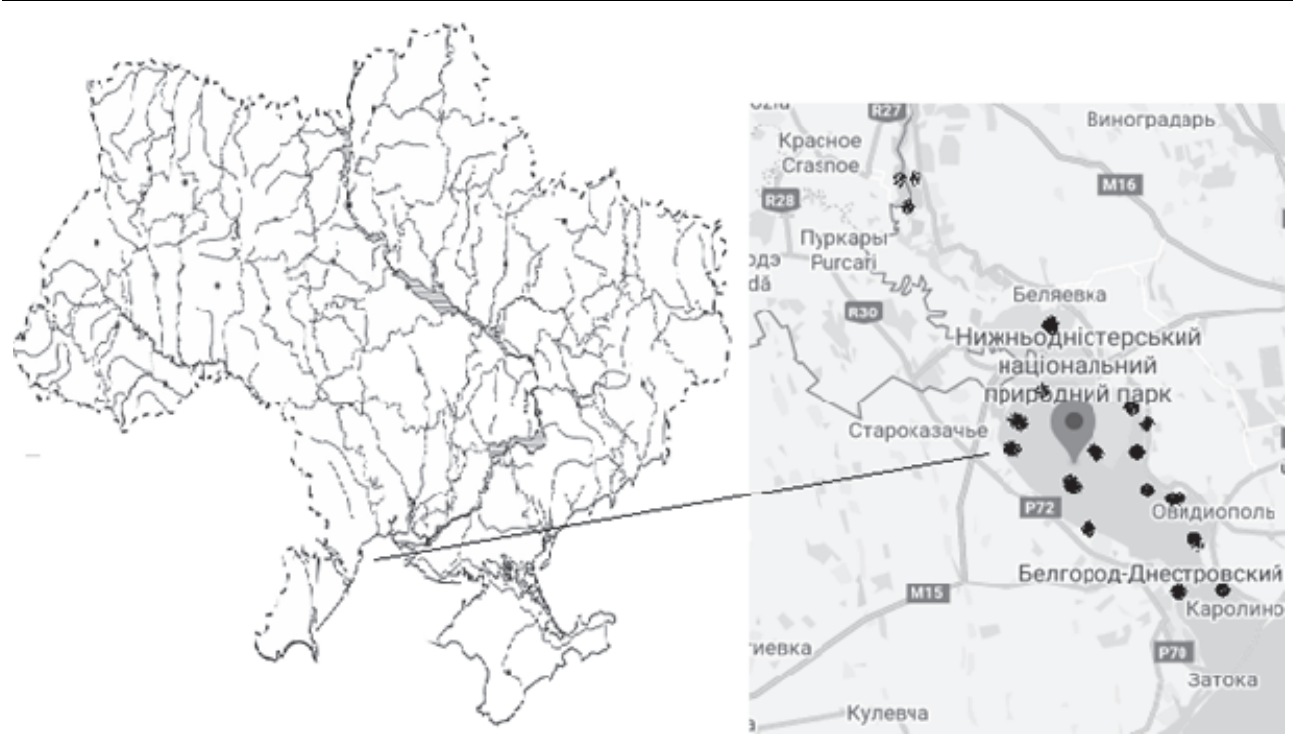

Fig. 2. Locations of $M$. nipponense sampling sites in the lower reaches of the

\section{Dniester River.}

The locations of $M$. nipponense shrimp in different waters of the Lower Dniester were determined from the shores, bridges and boats using a GPS navigator.

The highest abundance of $M$. nipponense was recorded in the Dniester lagoon (coordinates 46.209311, 30.7742). The density of shrimp per $1 \mathrm{~m}^{2}$ here reached 17 individuals $\cdot \mathrm{m}^{-2}$. Males predominated in the aggregations (sex ratio - 11: 6). The minimum density of shrimp (2.2 individuals $\cdot \mathrm{m}^{-2}$ ) was observed in the Bile Lake (coordinates 46.447324, 30.187776). The sex ratio here was 1: 1 (Fig. 3).

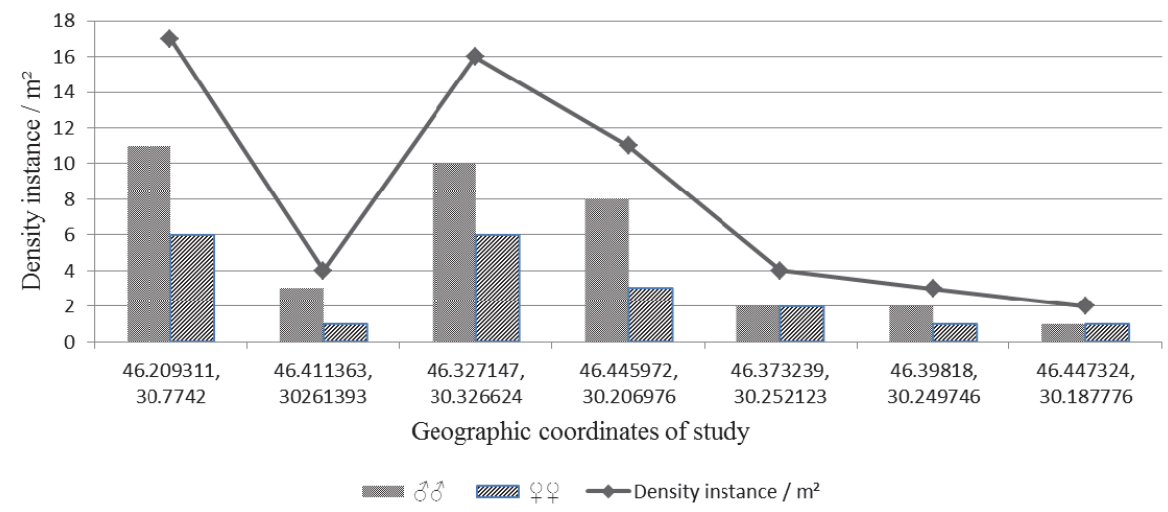

Fig. 3. Sex ratio and the density of $M$. nipponense in the water bodies of the lower Dniester

The density of shrimps in some water bodies of the lower Dniester varied significantly (4-9 times) during the day. The largest fluctuations in the numbers of shrimp were observed in the Dniester lagoon (coordinates 46.209311, 30.7742) and Kuchurgan lagoon (coordinates 46.636726, 29.957984). On-site observations at these 
two stations showed that the number of shrimp in the Dniester lagoon was higher than in the Kuchargan lagoon (Fig. 4).

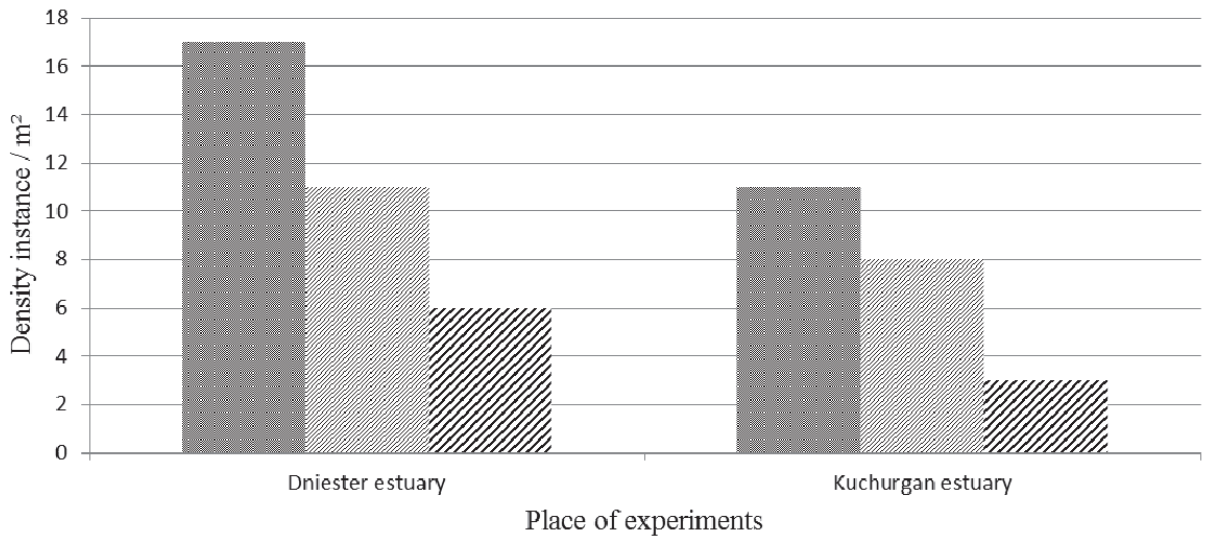

Density instance $/ \mathrm{m}^{2}$ 绻 80

Fig. 4. Density and sex ratio of $M$. nipponense articles at two sampling sites in the Dniester and Kuchurgan lagoons.

Such a population structure may indicate more favorable conditions for $M$. nipponense that have developed currently in the Dniester estuary.

It was found that the density of $M$. nipponense changed significantly during a day. A study of the dynamics of the abundance and density of shrimps at sampling sites in the Dniester and Kuchurgan lagoons showed that the diurnal fluctuations in their abundances had similar dynamics. The maximum abundance of shrimps was observed at four o'clock in the morning, gradually decreasing to 9 o'clock, followed by a sharp drop from 9 to 12 o'clock. In the next period from 12 to 24 hours, the density of shrimps was at a minimum, relatively stable level. From 1 o'clock at night there was a gradual increase in the number of shrimps to a maximum at four o'clock in the morning. It should be noted that this process was more dynamic in the Dniester lagoon and the fluctuations were more significant than in the Kuchurgan lagoon (Fig. 5).

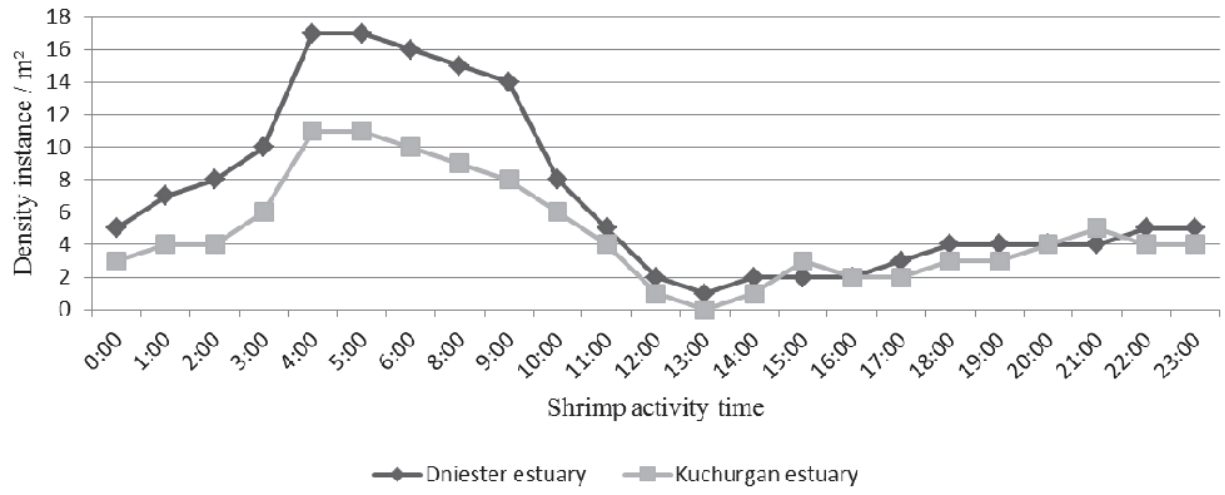

Fig. 5. Diurnal dynamics of $M$. nipponense density in open areas of Dniester and Kuchurgan lagoons (sampling sites) 


\section{CONCLUSIONS AND PROSPECTS FOR FURTHER DEVELOPMENT}

The rapid development of the world economy is a powerful anthropogenic factor that affects the distribution of plants and animals in terrestrial and aquatic ecosystems. Directed acclimatization and unauthorized introduction of organisms often leads to reversible, or more often, irreversible changes in biocenoses. The results of such changes require careful studies and evaluation.

M. nipponense, which penetrated into the Kuchurgan reservoir under the Soviet program of compensatory stocking in 1986, took its place in the benthic community of the biocenosis and established a stable population.

Currently, M. nipponense have spread to the lower reaches of the Dniester River, successfully reproduce, and their number is constantly growing. The highest density of $M$. nipponense was recorded in the Dniester lagoon $\left(17\right.$ individuals $\left.\cdot \mathrm{m}^{-2}\right)$, the lowest in the Bile Lake (2.2 individuals $-\mathrm{m}^{-2}$ ). Their sex ratio also differed significantly in different areas: from 1: 1 (Bile Lake) to 11: 6 (Dniester lagoon).

The density of $M$. nipponense varied significantly during a day. Thus, at sampling sites in the Dniester and Kuchurgan lagoons, diurnal fluctuations in their abundance a similar dynamics. The maximum number of shrimp was observed at four o'clock in the morning, gradually decreasing to 9 o'clock. In the period from 12 to 24 hours, the density of shrimp was at a minimum, relatively stable level. From 1 o'clock at night there is a gradual increase in the number of shrimp to a maximum. In the Dniester lagoon, the process was more dynamic, and the fluctuations were more significant than in the Kuchurhan lagoon.

The life cycle of $M$. nipponense in the Dniester River basin is synchronized and associated with natural rhythms that occur in their natural habitat.

\section{LITERATURE}

1. Биоразнообразие ракообразных Узбекистана / Мирабдуллаев И. И. и др. // Узбек. биол. журн. 1997. С. 51-52.

2. Буруковский Р. Н. Методика биологического анализа некоторых тропических и субтропических креветок // Промысловые исследования морских беспозвоночных. Москва : ВНИРО, 1992. С. 77-84.

3. Владимиров М. 3. Восточная речная креветка (Macrobrachium nipponense De Haan) - новый элемент гидрофауны Кучурганского водохранилища // Известия АН МССР. 1989. № 1. С. 77-78.

4. Гигиняк Ю. Г. Результаты интродукции субтропической пресноводной креветки Macrobrachium nipponense (De Haan) в водоем-охладитель Березовской ГРЭС (Беларусь) // VII Всероссийская конференция по промысловым беспозвоночным (памяти Б. Г. Иванова), Мурманск, 9-13 окт. 2006 г. : тезисы докл. Москва : ВНИРО, 2006. С. 276-277.

5. Гидрохимические особенности двух контрастных (Дубоссарского и Кучурганского) водохранилищ / Касапова Л. В. и др. // Интегрированное управление бассейном трансграничного Днестра: платформа для сотрудничества и современные вызовы : Междунар. конф., Тирасполь, 26-27 окт. 2017 г. : матер. Тирасполь : Eco-TIRAS, 2017. С. 164-166.

6. Кулеш В. Ф. Перспективы выращивания субтропической креветки Macrobrachium nipponense (De Haan) в водоемах-охладителях ТЭC // 
Биологические ресурсы водоемов в условиях антропогенного воздействия. Киев : Наукова думка, 1985. С. 34-36.

7. Современное состояние популяций чужеродных видов моллюсков в бассейн p. Днестр / Мунжиу О. В. и др. // Геоэкологические и биоэкологические проблемы Северного Причерноморья : V Междунар. науч.практ. конф., 14 ноября 2014 г. : матер. Тирасполь : ПГУ, 2014. С. 179-184.

8. Набиева К. Р. Пресноводные креветки в водоемах Арнасайской системы // Узбек. биол. журн. 1978. № 2. С. 55-57.

9. Нартыш О. М. Молдавская ГРЭС: дела и люди (Исторический очерк). Днестровск : Типар, 1998. 120 с.

10. Определитель пресноводных беспозвоночных России и сопредельных территорий. Ракообразные. Санкт-Петербург : ЗИН РАН, 1995. Т. 2.628 с.

11. Степанок Н. А. Восточная речная креветка рода Macrobrachium в низовье Днестра // Гидробиологический журнал. 2014. Т. 50, № 2. С. 117-120.

12. Филипенко С. И. О появлении пресноводной восточной креветки Macrobrachium nipponense (De Haan, 1849) в Днестре // Sustainable use and protection of animal world diversity. : International Symposium dedicated to 75 th anniversary of professor Andrei Munteanu : proceed. Chișinău, 2014. C. 206-207.

13. Филипенко С. И., Мустя М. В. О первой находке североамериканского краба Rhithropanopeus harrisi tridentata (Maitland, 1874) в Приднестровье // Озёрные экосистемы: биологические процессы, антропогенная трансформация, качество воды : V Междунар. науч. конф., 12-17 сент. 2016 г. : тезисы докл. Минск ; Нарочь: БГУ, 2016. С. 397-398.

14. Шекк П. В., Астафуров Ю. О. Можливість культивування східної субтропічної прісноводної креветки Macrobrachium nipponense (De Haan, 1849) в умовах нижнього Дністра // Сучасні проблеми теоретичної та практичної іхтіології : XII Міжнар. іхтіол. наук.-практ. конф. : матер. Дніпро, 2019. C. $232-235$.

15. Шекк П. В., Астафуров Ю. О. Проблема біологічних інвазій, вселення чужорідних видів на прикладі східної прісноводної креветки Macrobrachium nipponense (De Haan, 1849) // Студентська наукова конференція молодих вчених Одеського державного екологічного університету : збірник матер. Одесса, 2019. № 7. С. 102-103.

16. Cai Y., Ng P. K. L. The freshwater palaemonid prawns of Myanmar (Crustacea: Decapoda: Caridea) // Hydrobiologia. 2002. Vol. 487. P. 59-83.

17. Cai Y., Shokita S. Report on a collection of freshwater shrimps (Crustacea: Decapoda: Caridea) from the Philippines, with descriptions of four new species // Raffles Bulletin of Zoology. 2006. Vol. 54. P. 245-270.

18. Clark P. F., Abdul-Sahib I. M., Al-Asadi M. S. The first record of Eriocheir sinensis H. Milne Edwards, 1853 (Crustacea: Brachyura: Varunidae) from the Basrah Area of Southern Iraq // Aquatic Invasions. 2006. Vol. 1(2). P. 51-54.

19. Kutty M. N. Towards sustainable freshwater prawn aquaculture - lessons from shrimp farming, with special reference to India. Aquaculture Research. 2005. Vol. 36. P. 255-263.

20. Mirabdullaev I. M., Niyazov D. S. Alien decapods (Crustacea) in Uzbekistan // II International Symposium Invasion of alien species in Holarctic (BOROK-2), Borok, Russia, September 27- October 1, 2005 : abstracts. Borok 2005. P. 113114. 
21. The invasion of Macrobrachium nipponense (De Haan, 1849) (Caridea: Palaemonidae) into the Southern Iraqi marshes / Salman S. D. et al. // Aquatic Invasions. 2006. Vol. 1. P. 109-115.

22. Suzuki H., Kusamura T. Reexamination of the diagnostic characters of two freshwater palaemonid prawns, Macrobrachium nipponense (De Haan, 1849) and M. formosense Bate, 1868 (Decapoda, Caridea) from Japan // Crustaceana. 1997. Vol. 70. P. 831-839.

\section{REFERENCES}

1. Myrabdullaev, Y. Y., et al. (1997). Byoraznoobrazye rakoobraznykh Uzbekystana. Uzbek. byol. zhurn., 51-52.

2. Burukovskyi, R. N. (1992). Metodyka byolohycheskoho analyza nekotorbkh tropycheskykh y subtropycheskykh krevetok. Promyslovye issledovaniia morskykh bespozvonochnykh. Moskva: VNYRO, 77-84.

3. Vladymyrov, M. Z. (1989). Vostochnaia rechnaia krevetka (Macrobrachium nipponense De Haan) - novyi element hydrofauny Kuchurhanskoho vodokhranylyshcha. Yzvestyia AN MSSR, 1, 77-78.

4. Hyhyniak, Yu. H. (). Rezultaty yntroduktsyy subtropycheskoi presnovodnoi krevetky Macrobrachium nipponense (De Haan) v vodoem-okhladytel Berezovskoi HRES (Belarus). VII Vserossyiskaia konferentsyia po promыslovыm bespozvonochnыm (pamiaty B. H. Yvanova), Murmansk, 9-13 okt. 2006 h. : tezysы dokl. Moskva : VNYRO, 2006. S. 276-277.

5. Kasapova, L. V., Fylypenko, S. Y., Rudenko, A. K., \& Kalatynskaia, M. A. (2017). Hydrokhymycheskye osobennosty dvukh kontrastnykh (Dubossarskoho y Kuchurhanskoho) vodokhranylyshch. Yntehryrovannoe upravlenye basseinom transhranychnoho Dnestra: platforma dlia sotrudny-chestva y sovremennye vyzovy. Materyaly mezhdunarodnoi konferentsyy, Tyraspol, 26-27 oktiabria $2017 \mathrm{~h}$. Tyraspol: Eco-TIRAS, 164-166.

6. Kulesh, V. F. (1985). Perspektyvy vyrashchyvanyia subtropycheskoi krevetky Macrobrachium nipponense (De Haan) v vodoemakh-okhladyteliakh TES. Byolohycheskye resursy vodoemov $v$ uslovyiakh antropohennoho vozdeistvyia. Kyev: Naukova dumka, 34-36.

7. Munzhyu, O. V., Toderash, Y. K., Shubernetskyi, Y. V., Railian, N., \& Fylypenko, S. Y. (2014). Sovremennoe sostoianye populiatsyi chuzherodnykh vidov molliuskov v bassein r. Dnestr. Heoekolohycheskie y byoekolohycheskie problem Severnoho Prychernomoria. Materyaly V Mezhdunarodnoi nauchno praktycheskoi konferentsyy, 14 noiabria 2014 h. Tyraspol: PHU, 179-184.

8. Nabyeva, K. R. (1978). Presnovodnye krevetki v vodoemakh Arnasaiskoi systemy. Uzbek. byol. zhurn., 2, 55-57.

9. Nartysh, O. M. (1998). Moldavskaia HRES: dela y liudy (Istorycheskyi ocherk). Dnestrovsk: Typar.

10. Opredelytel presnovodnykh bespozvonochnykh Rossyy y sopredelnykh terrytoryi. Rakoobraznye. (Vol. 2). (1995). Sankt-Peterburh: ZYN RAN.

11. Stepanok, N. A. (2014). Vostochnaia rechnaia krevetka roda Macrobrachium v nyzove Dnestra. Hydrobyolohycheskyi zhurnal, 50(2), 117-120.

12. Fylypenko, S. Y. (2014). O poiavlenyy presnovodnoi vostochnoi krevetky Macrobrachium nipponense (De Haan, 1849) v Dnestre. Sustainable use and 
protection of animal world diversity: International Symposium dedicated to 75 th anniversary of professor Andrei Munteanu: proceed. Chișinău, 206-207.

13. Fylypenko, S. Y., \& Mustia, M. V. (2016). O pervoi nakhodke severoamerykanskoho kraba Rhithropanopeus harrisi tridentata (Maitland, 1874) v Prydnestrove. Oziornye ekosistemy: byolohycheskye protsessy, antropohennaia transformatsyia, kachestvo vody: Tez. dokl. V Mezhdunar. nauch. konf., 12-17 sentiabria 2016 h. Mynsk; Naroch: BHU, 397-398.

14. Shekk, P. V., \& Astafurov, Yu. O. (2019). Mozhlyvict kultyvuvannia skhidnoi subtropichnoi prisnovodnoi krevetky Macrobrachium nipponense (De Haan 1849) v umovakh nyzhnoho Dnistra. Suchasni problemy teoretychnoi ta praktychnoi ikhtiolohii: XII Mizhnar. ikhtiol. nauk.-prakt. konf.: mater. Dnipro, 232-235.

15. Shekk, P. V., \& Astafurov, Yu. O. (2019). Problema biolohichnykh invazii, vselennia chuzhoridnykh vydiv na prykladi skhidnoi prisnovodnoi krevetky Macrobrachium nipponense (De Haan 1849). Studentska naukova konferentsiia molodykh vchenykh Odeskoho derzhavnoho ekolohichnoho universytetu: zbirnyk mater. (Vol. 7). Odessa, 102-103.

16. Cai, Y., \& Ng, P. K. L. (2002). The freshwater palaemonid prawns of Myanmar (Crustacea: Decapoda: Caridea). Hydrobiologia, 487, 59-83.

17. Cai, Y., \& Shokita, S. (2006). Report on a collection of freshwater shrimps (Crustacea: Decapoda: Caridea) from the Philippines, with descriptions of four new species. Raffles Bulletin of Zoology, 54, 245-270.

18. Clark, P. F., Abdul-Sahib, I. M., \& Al-Asadi, M. S. (2006). The first record of Eriocheir sinensis H. Milne Edwards, 1853 (Crustacea: Brachyura: Varunidae) from the Basrah Area of Southern Iraq. Aquatic Invasions, 1(2), 51-54.

19. Kutty,, M. N. (2005). Towards sustainable freshwater prawn aquaculture - lessons from shrimp farming, with special reference to India. Aquaculture Research, 36, 255-263.

20. Mirabdullaev, I. M., \& Niyazov, D. S. (2005). Alien decapods (Crustacea) in Uzbekistan. II International Symposium Invasion of alien species in Holarctic (BOROK-2), Borok, Russia, September 27 - October 1, 2005 : abstracts. Borok, 113-114.

21. Salman, S. D., Page, T. J., Naser, M. D., \& Yasser, A. G. (2006). The invasion of Macrobrachium nipponense (De Haan, 1849) (Caridea: Palaemonidae) into the Southern Iraqi marshes. Aquatic Invasions, 1, 109-115.

22. Suzuki, H., \& Kusamura, T. (1997). Reexamination of the diagnostic characters of two freshwater palaemonid prawns, Macrobrachium nipponense (De Haan, 1849) and M. formosense Bate, 1868 (Decapoda, Caridea) from Japan. Crustaceana, 70, 831-839. 


\section{ТЕХНОЛОГІї В АКВАКУЛЬТУРІ}

Ribogospod. nauka Ukr., 2020; 2(52): 29-37

Received 18.04.20

DOI: https://doi.org/10.15407/fsu2020.02.029

УДК 639.371.2:639.3.03

Received in revised form 20.05.20

Accepted 02.05.20

\section{ВИРОЩУВАННЯ ЛИЧИНОК СТЕРЛЯДІ (ACIPENSER RUTHENUS LINNAEUS, 1758) У НЕТРАДИЦІЙНІ СТРОКИ}

О. М. Третяк, info@if.org.ua, Інститут рибного господарства НАAН, м. Київ

М. М. Пашко, marina-fish@ukr.net, Інститут рибного господарства НАAН, м. Київ

О. М. Колос, kolos-en@ukr.net, Інститут рибного господарства НАAН, м. Київ

Мета. Визначити основні рибницько-біологічні показники вирощування стерляді до життєстійких стадій у нетрадиційні ранньовесняні строки.

Методика. Зрілі статеві продукти стерляді отримували у нетрадиційні рибницькі строки (березень) від плідників, вирощених в умовах плавучих садків у водоймі з природним температурним режимом. Маса самок стерляді становила 2,6-3,1 ка (в середньому 2,8 ка). Роботи зі итучного відтворення стерляді проводили із застосуванням загальноприйнятих у осетрівництві методів після спеціальної температурної адаптації плідників у системі рециркулячійного водопостачання. Вільних ембріонів стерляді витримували за густоти посадки 5-7 тис. екз./ $\mathrm{M}^{2}$ у басейнах типу «ЦАА площею $4 \mathrm{M}^{2}$. У таких же басейнах вирощували стерлядь до життєстійких стадій за густоти посадки 1,5 тис. екз./ $\mathbf{M}^{2}$. Годівлю личинок здійснювали наупліями рачків Artemia із подальшим переведенням риб на споживання штучних кормів рекомендованих рецептур. Визначення рибницьких показників та фізико-хімічних параметрів середовища проводили, користуючись загальноприйнятими методиками.

Результати. У період інкубації ікри показник розвитку зародків стерляді на стадії гаструлячії становив у середньому 87,2\%. Виживання личинок за період витримування до переходу на активне живлення перебувало в межах 51,3-67,2\%. Вихід мальків стерляді наприкінці періоду вирощування, що тривав 42 доби, становив 61,3-73,8\%, за середньої маси риб 1,6-1,7 г. Установлено, що експериментальні групи риб за показниками росту $i$ виживання істотно не відрізнялись від потомства стерляді, отриманого у традиційні нерестові строки за інших технологічних схем сучасного осерівництва.

Наукова новизна. Досліджено особливості вирощування та рівень життєздатності потомства стерляді, отриманого в заводських умовах у нетрадиційні рибницькі терміни.

Практична значимість. Результати досліджень являють інтерес для розвитку сучасних методів аквакультури осетрових риб в умовах господарств індустріального типу.

Ключові слова: життєздатність стерляді, індустріальне рибництво, вирощування личинок, нетрадиційні строки.

\section{REARING STERLET (ACIPENSER RUTHENUS LINNAEUS, 1758) LARVAE IN NON-TRADITIONAL PERIODS}

A. Tretiak, info@if.org.ua, Institute of Fisheries NAAS, Kyiv

M. Pashko, marina-fish@ukr.net, Institute of Fisheries NAAS, Kyiv

Ye. Kolos, kolos-en@ukr.net, Institute of Fisheries NAAS, Kyiv

Purpose. To determine major aquaculture-biological parameters of rearing sterlet until viable stages during non-traditional early spring period.

() О. М. Третяк, М. М. Пашко, О. М. Колос, 2020 
Methodology. Mature sex products of sterlet were obtained during a non-traditional fish breeding period (March) from brood fish grown in floating cages in a water body with a natural temperature regime. The weight of sterlet females was $2.6-3.1 \mathrm{~kg}$ (2.8 kg on average). Artificial reproduction of sterlet was carried out using methods generally accepted in sturgeon culture after special temperature adaptation of brood fish in a recirculation water supply system. Sterlet free embryos were held with a stocking density of 5-7 thousand ind. $/ \mathrm{m}^{2}$ in "ICA"-type tanks with an area of $4 \mathrm{~m}^{2}$. Sterlet was grown in the same tanks to viable stages with a stocking density of 1.5 thousand ind./ $\mathrm{m}^{2}$. Larvae were fed with Artemia nauplii, followed by transfer to the consumption of artificial feeds of recommended formulations. Determination of fish breeding parameters and physicochemical parameters of the environment was carried out using conventional methods.

Findings. During the egg incubation period, the rate of development of sterlet embryos at the stages of gastrulation was $87.2 \%$ on average. Larval survival during the period before switching to active feeding was in the range of 51.3-67.2\%. The yield of sterlet fry at the end of the growing period, which lasted 42 days, was $61.3-73.8 \%$ with an average fish weight of of $1.6-1.7 \mathrm{~g}$. It was found that the experimental groups of fish did not differ significantly from by growth and survival parameters from sterlet offspring obtained during traditional spawning periods with other technological schemes of modern sturgeon culture.

Originality. Peculiarities of rearing and the level of viability of sterlet offspring of sterlet obtained under factory conditions during non-traditional fish breeding periods were studied.

Practical value. The study results are of interest for the development of modern aquaculture methods for sturgeons in the conditions of industrial fish farms.

Key words: sterlet viability, industrial aquaculture, larvae rearing, non-traditional periods.

\title{
ВЫРАЩИВАНИЕ ЛИЧИНОК СТЕРЛЯДИ (ACIPENSER RUTHENUS LINNAEUS, 1758) В НЕТРАДИЦИОННЫЕ СРОКИ
}

\author{
A. М. Третяк, info@if.org.ua, Институт рыбного хозяйства НАAН, г. Киев \\ М. М. Пашко, marina-fish@ukr.net, Институт рыбного хозяйства НАAН, г. Киев \\ Е. Н. Колос, kolos-en@ukr.net, Институт рыбного хозяйства НАAН, г. Киев
}

Цель. Определить основные рыбоводно-биологчческие показатели выращивания стерляди до жизнестойких стадий в нетрадиционные ранневесенние сроки.

Методика. Зрелые половые продукты стерляди получали в нетрадиционные рыбоводные сроки (март) от производителей, выращенных в условиях плавучих садков в водоеме с природным температурным режимом. Масса самок стерляди составляла 2,6-3,1 ка (в среднем 2,8 кг). Работы по искусственному воспроизводству стерляди проводили с использованием общепринятых в осетроводстве методов после специальной температурной адаптации производителей в системе рециркуляционного водоснабжения.

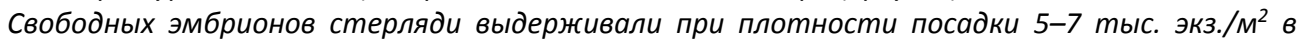
бассейнах типа "ИЦА» площадью $4 \mathrm{M}^{2}$. В таких же бассейнах выращивали стерлядь до жизнестойких стадий при плотности посадки 1,5 тыс. экз./м². Кормление личинок осуществляли науплиями рачков Artemia с последующим переводом рыб на потребление искусственных кормов рекомендованных рецептур. Определение рыбоводных показателей и физико-химических параметров среды проводили, пользуясь общепринятыми методиками.

Результаты. В период инкубации икры показатель развития зародышей стерляди на стадии гаструляции составлял в среднем 87,2\%. Выживание личинок за период выдерживания до перехода на активное питание находилось в пределах 51,3-67,2\%. Выход мальков стерляди в конце периода выращивания, который продолжался 42 суток, составлял 61,3-73,8\% при средней массе рыб 1,6-1,7 г. Установлено, что эксперементальные группы рыб по показателям роста и выживания существенно не отличались от потомства стерляди, полученного в традиционные нерестовые сроки при других технологических схемах современного осетроводства. 
Научная новизна. Исследованы особенности выращивания и уровень жизнеспособности потомства стерляди, полученного в заводских условиях в нетрадиционные рыбоводные сроки.

Практическая значимость. Результаты исследований представляют интерес для развития современных методов аквакультуры осетровых рыб в условиях хозяйств индустриального типа.

Ключевые слова: жизнеспособность стерляди, индустриальное рыбоводство, выращивание личинок, нетрадиционные сроки.

\section{ПОСТАНОВКА ПРОБЛЕМИ ТА АНАЛІЗ ОСТАННІХ ДОСЛІДЖЕНЬ І ПУБЛІКАЦІЙ}

Інтенсивна та неконтрольована промислова експлуатація світових запасів осетрових риб упродовж тривалого часу за широкомасштабного порушення екологічних умов для їх природного розмноження, стали тими вирішальними чинниками, що призвели до повсюдного зменшення чисельності осетрових популяцій [1-3].

Зазначені обставини спонукають до прискореного розвитку промислових технологій відтворення і вирощування цих риб в аквакультурі. Удосконалення методів культивування осетрових риб має ключове значення не лише для ефективного виконання природоохоронних заходів 3 відновлення чисельності осетрових популяцій, але й ще більшою мірою сприятиме насиченню рибного ринку продукцією осетрівництва [2, 3, 4-7].

\section{ВИДІЛЕННЯ НЕВИРІШЕНИХ РАНІШЕ ЧАСТИН ЗАГАЛЬНОЇ ПРОБЛЕМИ. МЕТА РОБОТИ}

Важливе значення для прискореного розвитку сучасного осетрівництва належить індустріальним методам культивування осетрових риб 3 метою виробництва чорної харчової ікри [8-10].

При цьому одним із поширених технологічних варіантів ікряно-товарного осетрівництва $\epsilon$ комбіноване формування та експлуатація маточних стад стерляді із використанням садкових рибницьких систем для вирощування плідників у поєднанні зі штучним отриманням овульованої ікри в умовах рециркуляційних установок водозабезпечення. Характерною особливістю цісї технологічної схеми $\epsilon$ проведення рибницьких робіт 3 отримання зрілих статевих продуктів риб 3 істотним зміщенням традиційних нерестових строків [11-13]. До недостатньо вивчених рибницько-біологічних аспектів указаної технології інтенсивного осетрівництва слід віднести оцінку рівня життєздатності личинок і мальків стерляді, отриманих в результаті штучного відтворення у нетрадиційні строки. Цим насамперед обгрунтовується актуальність та новизна проведених досліджень. Отже, метою досліджень було визначення основних рибницькобіологічних показників у процесі вирощування стерляді до життєстійких стадій у нетрадиційні рибницькі строки.

\section{МАТЕРІАЛИ ТА МЕТОДИ}

Збір експериментальних матеріалів проводили у 2015 р. на базі рибогосподарського підприємства ТОВ-СРП «Осетр» Київської області. Досліджували потомство стерляді, отримане в заводських умовах від самок 
масою 2,6-3,1 кг (в середньому 2,8 кг). Маса використаних у рибницьких роботах самців стерляді становила 1,6-2,6 кг (в середньому 2,0 кг). Вирощування плідників проводилось в умовах плавучих садків, установлених у водоймі 3 природним температурним режимом.

Отримання зрілих статевих продуктів від плідників здійснювали у нетрадиційні для відтворення стерляді ранньовесняні строки (березень), які більше ніж на місяць випереджали традиційний нерестовий період. Роботи виконували із застосуванням внутрішньом'язових ін'єкцій риб суспензією препарату зневоднених гіпофізів осетрових риб. Відбір овульованої ікри від самок риб проводили прижиттєво після підрізання яйцепроводів [14]. Знеклеювали запліднену ікру із використанням розчину таніну. Для інкубації ембріонів застосовували апарати Вейса об'ємом 8 л. Експериментальні роботи здійснювали в умовах інкубаційно-личинкового цеху обладнаного системою рециркуляційного водопостачання за тривалої адаптації плідників до нерестових параметрів температури води [12].

Після вилуплення з оболонок передличинок стерляді витримували за густоти посадки 5-7 тис. екз./ м $^{2}$ у пластикових басейнах типу «ІЦА» площею $4 \mathrm{~m}^{2}$. У таких же басейнах відбувалось вирощування молоді стерляді до життєстійких стадій за початкової густоти посадки 1,5 тис. екз./ $\mathbf{m}^{2}$. Годівлю личинок здійснювали наупліями рачків Artemia із подальшим переведенням на годівлю штучними кормами для молоді риб, рекомендованих у сучасному осетрівництві рецептур.

Визначення рибницько-біологічних показників експериментальних груп стерляді та фізико-хімічних параметрів водного середовища проводили, користуючись загальноприйнятими в рибництві та гідрохімії методиками [15-17].

\section{РЕЗУЛЬТАТИ ДОСЛІДЖЕНЬ ТА ЇХ ОБГОВОРЕННЯ}

У період проведення рибницьких робіт 3 відтворення стерляді та вирощування iï молоді до життєстійких стадій вміст розчиненого у воді кисню підтримували на рівні, близькому до 8-9 мг $\mathrm{O}_{2} /$ дм³ $^{3}$. Водневий показник $(\mathrm{pH})$ води становив 7,8-8,0. Вода характеризувалась середнім ступенем мінералізації із сумою йонів до 366,1 мг/дм ${ }^{3}$ i за класифікацією О.О. Альокіна належала до гідрокарбонатного класу групи кальцію. Істотних перевищень нормативних значень за рештою гідрохімічних показників не виявлено. Отже, якість води, що використовувалась у процесі виконання експериментів, в цілому відповідала вимогам для культивування осетрових риб за індустріальних технологій.

У результаті проведення рибницьких робіт з отримання овульованої ікри стерляді в заводських умовах від самок масою 2,6-3,1 кг зареєстровано високі показники робочої плодючості, що змінювались у межах 31,85-50,00 тис. ікринок, за середньої величини показника 43,29 тис. ікринок. Активність сперміїв у статевих продуктах, відібраних від самців масою 1,6-2,6 кг, становила 50-90\%.

За середньої температури води $14,5^{\circ} \mathrm{C}$ показники розвитку зародків стерляді в період інкубації на стадії середньої гаструли становили 53-97\% за досить високої середньої величини - на рівні 87,2\%. Частка виходу ембріонів з оболонок від проміжних спостережень на стадіях гаструляції змінювалась у межах 76-89\% і в середньому становила 83,7\%. Тобто, за весь період інкубації вихід вільних 
ембріонів від кількості ікри коливався у межах 40-86\% за середнього рівня 73,5\%.

На початку періоду витримування в басейнах, який за середньої температури води $16,2^{\circ} \mathrm{C}$ тривав до 8-10 діб, маса передличинок стерляді змінювалась у межах 8-12 мг за середнього показника 10,57 мг. На завершальному етапі витримування після переходу на екзогенне живлення маса личинок зросла до 18-25 мг і в середньому становила 21,88 мг. Рівень виходу личинок після періоду витримування в середньому становив $60,3 \%$ за коливань показника в окремих басейнах від 51,3 до 67,2\%.

Певні відмінності у розмірах і розвитку передличинок, а в подальшому i личинок стерляді під час переходу на активне живлення значною мірою пов'язані 3 довготривалістю (понад півтори-дві доби) періоду вилуплення вільних ембріонів з ікринок. Це зумовлювало завчасний початок обмеженої годівлі риб, ще за кілька діб до переходу на зовнішне живлення переважної більшості личинок. Згодовування штучних кормів у чистому вигляді здійснювали за розробленими графіками годівлі після досягнення личинками стерляді середньої маси не менше 200-230 мг. На початкових етапах вирощування личинкам згодовували науплій рачків Artemia. Починаючи 3 6-8-ї доби вирощування, личинок привчали до штучного корму із поступовим збільшенням його добових доз. Водночас поступово скорочували (щоденно на 10-15\%) кількість згодованих живих кормів. У період адаптації личинок стерляді до штучних кормів застосовували додаткову підгодівлю стерляді сирою масою подрібненого трубочника (Tubificidae), добова норма задавання якої не перевищувала 10-15\% від маси риб. Перед згодовуванням черв'яків до трьох діб витримували під чистою проточною водою, регулярно відокремлюючи відмерлих організмів.

У процесі вирощування личинок стерляді температуру води підтримували в межах $17-21^{\circ} \mathrm{C}$, поступово підвищуючи температурні значення впродовж періоду проведення експериментів. У результаті, за 42 доби вирощування із початковою густоти посадки 1,5 тис. екз./M를 досліджувані групи стерляді досягли середньої маси 1596,4-1734,4 мг, за виходу 61,3-73,8\% (табл. 1).

Таблиия 1. Результати вирощування стерляді до життсстійких стадій Table 1. Results of sterlet (Acipenser ruthenus) growing to viable stages

\begin{tabular}{|c|c|c|c|c|c|}
\hline \multirow{2}{*}{$\begin{array}{l}\text { Дослідний басейн № / } \\
\text { Experimental pool, № }\end{array}$} & \multicolumn{4}{|c|}{$\begin{array}{c}\text { Маса мальків, } \mathrm{mr}(n=25) / \\
\text { Weight of fry, } \mathrm{mg}(\mathrm{n}=25)\end{array}$} & \multirow{2}{*}{$\begin{array}{l}\text { Вихід, \% / } \\
\text { Harvest, \% }\end{array}$} \\
\hline & $M \pm m$ & $\max$ & $\min$ & $C_{v}, \%$ & \\
\hline 1 & $1734,40 \pm 114,47$ & 3040 & 890 & 33,00 & 61,3 \\
\hline 2 & $1649,60 \pm 134,81$ & 2930 & 820 & 40,86 & 73,8 \\
\hline 3 & $1596,40 \pm 121,08$ & 2950 & 730 & 37,92 & 66,5 \\
\hline
\end{tabular}

3 таблиці видно, що найбільші середні величини маси тіла мальків зареєстровано у басейні № 1 за мінімального рівня виживання риб. Рибопродуктивність у басейні за цих умов становила 398,9 г/ $\mathrm{M}^{2}$. В інших басейнах за найвищого $(73,8 \%)$ та середнього $(66,5 \%)$ показників виживання риб рівень

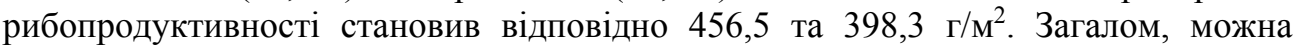
відмітити подібність рибницько-біологічних показників упродовж всього періоду вирощування в трьох дослідних басейнах. Показники середньої маси різновікової 
молоді стерляді на кожному із контрольних проміжків вирощування не відрізнялись більше ніж на 7,8-9,4\%. Виявлені закономірності можуть бути побічним підтвердженням достатнього рівня життєздатності потомства стерляді, отриманого в заводських умовах у нетрадиційні нерестові строки від «садкових» плідників, вирощених за інтенсивної технології індустріального рибництва.

У процесі вирощування основний відхід личинок стерляді (до 25-30\%) спостерігався протягом першої половини періоду досліджень, насамперед упродовж першої десятиденки. На наступному етапі відхід досліджуваних груп риб не перевищував 6-9\%. Рівень виживання мальків в останню декаду досліджень наближався до 99-100\%.

Абсолютні добові прирости маси молоді стерляді на різних етапах вирощування характеризувались певними відмінностями і зростали з 5,72-6,53 мг у перший тиждень спостережень до 51,40-68,49 мг протягом другої половини досліджуваного періоду. За весь проаналізований 42-добовий період абсолютний добовий приріст стерляді у різних басейнах характеризувався близькими середніми величинами, що перебували в межах 37,49-40,77 мг/добу (табл. 2). Дещо іншою динамікою відрізнявся відносний добовий приріст риб. Протягом перших двох тижнів експериментів відносний середній приріст характеризувався достатньою стабільністю на рівні $26,89-28,12 \%$ за добу з наступним зниженням в середньому до 13,69-15,57\% за добу впродовж третього і четвертого тижнів досліджень. В останні два тижні вирощування відносний добовий приріст мальків стерляді зменшився до рівня 7,90-8,83\%.

Таблиия 2. Середньодобові прирости маси тіла стерляді в період вирощування до життсстійких стадій

Table 2. Average daily weight gain of sterlet (Acipenser ruthenus), during the growing period to viable stages

\begin{tabular}{|c|c|c|c|c|c|c|}
\hline \multirow{2}{*}{ Басейн, № / Pool, № } & \multicolumn{6}{|c|}{ Період вирощування, доба / Growing period, day } \\
\hline & $0-7$ & 8-14 & $15-21$ & $22-28$ & $29-42$ & 0-42 \\
\hline \multirow{2}{*}{1} & $\underline{6,21}$ & $\underline{18,79}$ & $\underline{26,42}$ & $\underline{56,25}$ & $\underline{68,49}$ & $\underline{40,77}$ \\
\hline & 28,38 & 28,76 & 13,42 & 14,73 & 8,83 & 186,35 \\
\hline \multirow{2}{*}{2} & $\underline{5,72}$ & $\underline{17,49}$ & $\underline{23,07}$ & $\underline{62,48}$ & $\underline{61,89}$ & $\underline{38,76}$ \\
\hline & 26,14 & 28,25 & 12,51 & 18,07 & 7,90 & 177,13 \\
\hline \multirow{2}{*}{3} & $\underline{6,53}$ & $\underline{16,00}$ & $\underline{27,12}$ & $\underline{51,40}$ & $\underline{61,91}$ & $\underline{37,49}$ \\
\hline & 29,84 & 23,67 & 15,13 & 13,90 & 8,49 & 171,34 \\
\hline \multirow{2}{*}{ Середнє / Average } & $\underline{6,15}$ & $\underline{17,43}$ & $\underline{25,54}$ & $\underline{56,71}$ & $\underline{64,10}$ & $\underline{39,01}$ \\
\hline & 28,12 & 26,89 & 13,69 & 15,57 & 8,41 & 178,27 \\
\hline
\end{tabular}

Примітка. Над рискою - абсолютний добовий приріст, мг; під рискою - відносний добовий приріст, \%.

Note. Above the line is the absolute daily weight gain, $\mathrm{mg}$; under the line is the relative daily weight gain,\%.

Аналізуючи особливості росту стерляді, можна припустити, що виявлені відмінності приростів риб в окремі проміжки часу пояснюються не лише закономірними змінами темпу росту старших особин, але й впливом низки технологічних чинників. Зокрема, збереження досить високих добових приростів 
стерляді упродовж другого-четвертого тижнів вирощування значною мірою пов'язане iз забезпеченням повноцінної годівлі риб та сприятливого температурного режиму водного середовища у межах $18-20^{\circ} \mathrm{C}$ за вмісту розчиненого у воді кисню на оптимальному рівні - не нижче 8 мг $\mathrm{O}_{2} /$ дм$^{3}$. У цей період личинок стерляді переводили на переважне живлення стартовими комбікормами високої якості. Водночас, певне уповільнення відносних приростів риб на завершальному етапі вирощування могло бути наслідком як змін потенційних можливостей росту личинкового та малькового етапів розвитку стерляді, так і збільшенням біомаси осетрової молоді із напруженням конкуренції у живленні між окремими особинами.

На наступному етапі виконання рибницьких робіт, 3 метою отримання посадкового матеріалу для зариблення садків, стерлядь продовжували вирощувати у басейнах до досягнення середньої маси 3-5 г. Вирощування цьоголіток на цьому етапі відбувалося практично без відходу (зареєстровано загибель поодиноких риб). Загальний термін вирощування стерляді до середньої маси 2,5-3,0 г від зариблення басейнів личинками, що перейшли на екзогенне живлення, становив понад 50 діб.

\section{ВИСНОВКИ ТА ПЕРСПЕКТИВИ ПОДАЛЬШОГО РОЗВИТКУ}

За результатами проведених досліджень, слід відмітити високі репродуктивні можливості плідників стерляді у процесі заводського відтворення у нетрадиційні нерестові строки та задовільні показники життєздатності отриманого від них потомства, що вирощувалось до життестійких стадій в умовах пластикових басейнів із засобами рециркуляційного водопостачання. Середній рівень робочої плодючості самок масою 2,8 кг становив 43,29 тис. ікринок, за середнього показника виходу вільних ембріонів від заплідненої ікри 73,5\%. Середня маса мальків стерляді в результаті 42-добового вирощування змінювалась у межах 1,61,7 г за виживання $61,3-73,8 \%$.

Таким чином, за визначеними рибницько-біологічними критеріями оцінки життєздатності досліджувані групи стерляді не поступались потомству цього представника осетрових риб, отриманому за інших технологічних схем у звичайні нерестові строки. На це вказують порівняльні дані, наведені у літературі [18-20].

Зважаючи на низку важливих переваг розглянутих технологічних рішень, дослідження даного спрямування слід продовжити у різні періоди зимового сезону. Насамперед, це сприятиме істотному подовженню технологічного етапу, необхідного для вирощування високоякісного рибопосадкового матеріалу 3 поліпшеними розмірно-ваговими кондиціями 3 метою вирощування в аквакультурі. Водночас, висока ефективність вирощування рибопосадкового матеріалу матиме вирішальне значення для організації робіт 3 відновлення чисельності популяцій осетрових риб.

\section{ЛІТЕРАТУРА}

1. Шерман I. М., Корнієнко В. О., Шевченко В. Ю. Актуальність та передумови доместикації представників родини осетрових в умовах півдня України // Таврійський науковий вісник. 2006. Вип. 44. С. 145-154.

2. Стан запасів осетрових риб та розвиток осетрової аквакультури в Україні / Третяк О. М. та ін. // Рибогосподарська наука України. 2010. № 4. С. 4-22.

3. Кольман Р. Искусственное размножение осетровых рыб // Проблемы 
производства посадочного материала исчезающих популяций осетровых рыб. Ольштын : MIR DRUK, 2012. C. 31-43.

4. Васильева Л. М. Биологические и технологические особенности товарной аквакультуры осетровых в условиях Нижнего Поволжья. Астрахань : ФГУП НПЦ «Биос», 2000. С. 139-148.

5. Козлов В. И., Козлов А. В. Осетроводство. Москва : МГУТУ, 2011. 336 с.

6. Кончиц В. В. Первоочередные задачи развития осетроводства в республике Беларусь // Рибогосподарська наука України. 2008. № 4. С. 68-72.

7. Хрусталев Е. В., Куранова Т. М., Хойновский К. Б. Искусственное воспроизводство стерляди Acipenser ruthenus L. // Биотехника искусственного воспроизводства рыб, раков и сохранение запасов промысловых рыб. Вильнюс, 2008. С. 8 - 16.

8. Начало официального производства пищевой икры осетровых рыб, выращенных в рыбоводных хозяйствах / Подушка С. Б. и др. // Научно-технический бюллетень лаборатории ихтиологии ИНЭНКО. 2005. № 9. С. 5-11.

9. Подушка С. Б., Чебанов М. С. Икорно-товарное осетроводство в Китае // Научно-технический бюлетень лаборатории ихтиологии ИНЭНКО. 2007. № 13. С. 5-15.

10. Подушка С. Б., Армянинов И. В. Опыт формирования и эксплуатации икорнотоварного стада стерляди в Кармановском рыбхозе // Осетровое хазяйство. 2008. № 1. C. $2-5$.

11. Пашко М. М., Третяк О. М., Колос О. М. Результати експериментів зі штучного отримання овульованої ікри від плідників стерляді Acipenser ruthenus Linnaeus у нетрадиційні строки // Рибогосподарська наука України. 2018. № 2. С. $81-88$.

12. Результати штучного відтворення осетрових риб, вирощених у садках за природного температурного режиму водойм лісостепової зони України / Пашко М. М. та ін. // Рибогосподарська наука України. 2018. № 3. С. 39-49.

13. Пашко М. М., Третяк О. М., Колос О. М. До питання вирощування плідників стерляді (Acipenser ruthenus Linnaeus) у плавучих садках за природної температури води Лісостепу України // Рибогосподарська наука України. 2019. № 1. С. $48-59$.

14. Подушка С. Б. Прижизненное получение икры у осетровых рыб / Биологические ресурсы и проблемы развития аквакультуры на водоеме Урала и Западной Сибири : Всеросс. конф., Тюмень, 17-18 сент. 1996 г. : тез. докл. Тюмень, 1996. С. 17-18.

15. Правдин И. Ф. Руководство по изучению рыб. Москва : Пищевая промышленность. 1966. 375 с.

16. Алекин О. А., Семенов А. Д., Скопинцев Б. А. Руководство по химическому анализу вод суши. Ленинград : Гидрометеоиздат, 1973. 270 с.

17. СОУ - 05.01.37-385:2006. Вода рибогосподарських підприємств. Загальні вимоги та норми. Київ : Міністерство аграрної політики України. 2006. 7 с.

18. Рекомендации по выращиванию стерляди. Киев : Укррыбхоз, 1993. $28 \mathrm{c}$.

19. Еколого-технологічні основи відтворення i вирощування молоді осетроподібних / Шерман I. М. та ін. Херсон : Олді-плюс, 2009. 348 с.

20. Кононенко I. С. Оцінка виживаності молоді стерляді, отриманої від кріоконсервованої сперми // Тваринництво України. 2017. № 3-4. C. $31-35$. 


\section{REFERENCES}

1. Sherman, I. M., Korniienko, V. O., \& Shevchenko, V. Yu. (2006). Aktualnist ta peredumovy domestykatsii predstavnykiv rodyny osetrovykh $\mathrm{v}$ umovakh pivdnia Ukrainy. Tavriiskyi naukovyi visnyk, 44, 145-154.

2. Tretiak, O. M., et al. (2010). Stan zapasiv osetrovykh ryb ta rozvytok osetrovoi akvakultury v Ukraini. Rybohospodarska nauka Ukrainy, 4, 4-22.

3. Kol'man, R. (2012). Iskusstvennoe razmnozhenie osetrovykh ryb. Problemy proizvodstva posadochnogo materiala ischezayushchikh populyatsiy osetrovykh ryb. Ol'shtyn: MIR DRUK, 31-43.

4. Vasil'eva, L. M. (2000). Biologicheskie i tekhnologicheskie osobennosti tovarnoy akvakul'tury osetrovykh $v$ usloviyakh Nizhnego Povolzh'ya. Astrakhan': FGUP NPTs «Bios», 139-148.

5. Kozlov, V. I., \& Kozlov, A. V. (2011). Osetrovodstvo. Moskva: MGUTU.

6. Konchits, V. V. (2008). Pervoocherednye zadachi razvitiya osetrovodstva v respublike Belarus'. Rybohospodarska nauka Ukrainy, 4, 68-72.

7. Khrustalev, E. V., Kuranova, T. M., \& Khoynovskiy, K. B. (2008). Iskusstvennoe vosproizvodstvo sterlyadi Acipenser ruthenus L. Biotekhnika iskusstvennogo vosproizvodstva ryb, rakov i sokhranenie zapasov promyslovykh ryb. Vil'nyus, 8-16.

8. Podushka, S. B. et al. (2005). Nachalo ofitsial'nogo proizvodstva pishchevoy ikry osetrovykh ryb, vyrashchennykh $\mathrm{v}$ rybovodnykh khozyaystvakh. Nauchnotekhnicheskiy byulleten' laboratorii ikhtiologii INENKO, 9, 5-11.

9. Podushka, S. B., \& Chebanov, M. S. (2007). Ikorno-tovarnoe osetrovodstvo v Kitae. Nauchno-tekhnicheskiy byuleten' laboratorii ikhtiologii INENKO, 13, 5-15.

10. Podushka, S. B., \& Armyaninov, I. V. (2008). Opyt formirovaniya i ekspluatatsii ikorno-tovarnogo stada sterlyadi $\mathrm{v}$ Karmanovskom rybkhoze. Osetrovoe khazyaystvo, 1, 2-5.

11. Pashko, M. M., Tretiak, O. M., \& Kolos, O. M. (2018). Rezultaty eksperymentiv zi shtuchnoho otrymannia ovulovanoi ikry vid plidnykiv sterliadi Acipenser ruthenus Linnaeus u netradytsiini stroky. Rybohospodarska nauka Ukrainy, 2, 81-88.

12. Pashko, M. M. (2018). Rezultaty shtuchnoho vidtvorennia osetrovykh ryb, vyroshchenykh u sadkakh za pryrodnoho temperaturnoho rezhymu vodoim lisostepovoi zony Ukrainy. Rybohospodarska nauka Ukrainy, 3, 39-49.

13. Pashko, M. M., Tretiak, O. M., \& Kolos, O. M. (2019). Do pytannia vyroshchuvannia plidnykiv sterliadi (Acipenser ruthenus Linnaeus) u plavuchykh sadkakh za pryrodnoi temperatury vody Lisostepu Ukrainy. Rybohospodarska nauka Ukrainy, 1, 48-59.

14. Podushka, S. B. (1996). Prizhiznennoe poluchenie ikry u osetrovykh ryb. Biologicheskie resursy i problemy razvitiya akvakul'tury na vodoeme Urala i Zapadnoy Sibiri: Vseross. konf., Tyumen', 17-18 sent. 1996 g.: tez. dokl. Tyumen', 17-18.

15. Pravdin, I. F. (1966). Rukovodstvo po izucheniyu ryb. Moskva: Pishchevaya promyshlennost'.

16. Alekin, O. A., Semenov, A. D., \& Skopintsev, B. A. (1973). Rukovodstvo po khimicheskomu analizu vod sushi. Leningrad: Gidrometeoizdat.

17. Voda rybohospodarskykh pidpryiemstv. Zahalni vymohy ta normy. (2006). SOU 05.01.37-385:2006. Kyiv: Ministerstvo ahrarnoi polityky Ukrainy.

18. Rekomendatsii po vyrashchivaniyu sterlyadi (1993). Kiev: Ukrrybkhoz.

19. Sherman, I. M. (2009). Ekoloho-tekhnolohichni osnovy vidtvorennia $i$ vyroshchuvannia molodi osetropodibnykh. Kherson: Oldi-plius.

20. Kononenko, I. S. (2017). Otsinka vyzhyvanosti molodi sterliadi, otrymanoi vid kriokonservovanoi spermy. Tvarynnytstvo Ukrainy, 3-4, 31-35. 


\section{КОРМИ ТА ГОДІВЛЯ}

Ribogospod. nauka Ukr., 2020; 2(52): 38-52

Received 21.04.20

DOI: https://doi.org/10.15407/fsu2020.02.038

УДК [639.3.043:636.087.73]:639.371.52

Received in revised form 22.05.20

Accepted 04.06.20

\section{ПРОДУКТИВНІ ТА ВІДТВОРНІ ПОКАЗНИКИ КОРОПА ЗА ВВЕДЕННЯ ДО СКЛАДУ КОРМУ АМАРАНТА}

P. А. Паламарчук, feeding@if.org.ua, Інститут рибного господарства НАAН, м. Київ

О. В. Дерень, derenj@ukr.net, Інститут рибного господарства НАAН, м. Київ

С. А. Коба, koba sveta@i.ua, Інститут рибного господарства НАAН, м. Київ

Мета. Вивчення впливу кормової добавки амаранта на продуктивність та економічну складову при вирощуванні дворічок коропа; а також на репродуктивні показники самиць коропа, виходячи з аналізу поживності амаранта та його біологічно активних властивостей.

Методика. Проведено два досліди, в межах яких проаналізовано вплив згодовування дволіткам та самицям коропа зерна українського високоврожайного кормового сорту амаранту з біологічно активними властивостями “Харківський-1» на фізіологічні та продуктивні показники. В годівлі коропа використовували гранульований комбікорм 3 вмістом протеїну на рівні 23\%, до складу якого додатково вводили мелене насіння амаранта методом гранулювання в кількості 10\% на заміщення злакової складової, попередньо піддавии термічній обробці. Рибницькі, селекційні, гідрохімічні та гідробіологічні дослідження проведено за загальноприйнятими методиками.

Результати. Встановлено, що основні гідрохімічні показники знаходились у межах рибницьких норм. Показники розвитку фіто-, зоопланктону та зообентосу в середньому за сезон як за кількістю, так і за біомасою практично не відрізнялися в обох ставах.

При визначенні ефективності застосування змеленого насіння амаранта в годівлі дворічок коропа впродовж всього сезону вирощування в складі збалансовано комбікорму встановлено покращення рибницьких показників. Зокрема, середня маса виловленої риби у кінці вегетаційного періоду в дослідній групі була на 10,5\%, відповідно, рибопродуктивність - на 12,2\% більшою, ніж у контролі, а витрати корму на вирощування - нижчими на 10,3\%. Враховуючи вартість посадкового матеріалу $і$ витрачених на вирощування кормів, отримано 9,3\% додаткового прибутку за згодовування амаранта.

Визначено, що додавання до раціону самиць коропів амаранта впродовж переднерестового утримання позитивно впливало на продукування ікри, ії заплідну здатність, а також на життєздатність отриманих личинок. Відповідно, відмічено підвищення відносної робочої плодючості на 3,4\%, запліднення ікри на 3\%, та виходу 3добових личинок на 6,7\% в дослідній групі.

Наукова новизна. При проведенні досліджень, виходячи з аналізу поживності ma біологічно активних властивостей амаранта, вперше вивчено його вплив на продуктивні показники дволіток та відтворну здатність самиць коропа, а також визначено ефективність його використання в складі раціону.

Практична значимість. Пошук кормових компонентів, які характеризуються високим вмістом протеїну та придатні для інтродукції в природних умовах нашої країни, $\epsilon$ актуальним і необхідним для забезпечення потреб рибогосподарської галузі. Відповідно до

(ㄱ Р. А. Паламарчук, О. В. Дерень, С. А. Коба, 2020 
результатів дослідження, введення амаранта до складу раціону різновікових груп коропа матиме позитивний вплив на приріст, рівень виживання та репродуктивні показники, а також дозволить зменшити кормовий коефріцієнт.

Ключові слова: амарант, короп, продуктивність, репродуктивні показники, витрати корму, виживаність, ефективність.

\title{
PRODUCTIVE AND REPRODUCTIVE PARAMETERS OF CARP WHEN ADDING AMARANTH SEEDS TO FISH FEED
}

\author{
R. Palamarchuk, feeding@if.org.ua, Institute of Fisheries NAAS, Kyiv \\ O. Deren, derenj@ukr.net, Institute of Fisheries NAAS, Kyiv \\ S. Koba, koba sveta@i.ua, Institute of Fisheries NAAS, Kyiv
}

Purpose. Study of the effect of amaranth feed additive on the peculiarities of growth, development, feed efficiency and economic component when rearing age-1+carp; as well as the reproductive performance of female carp based on an analysis of its nutritional and biologically active properties.

Methodology. Two experiments were conducted in which the effect of feeding of age-1+ and female carp with seeds of Ukrainian high-yielding forage amaranth with biologically active properties "Kharkiv-1" on physiological and productive parameters was analyzed. Carp were fed with granulated compound feed with a protein content of $23 \%$, which was additionally supplemented with ground amaranth seeds by granulation method in the amount of $10 \%$ to replace the cereal component, presubjected to heat treatment. Piscicultural, breeding, hydrochemical and hydro-biological studies were carried out according to conventional aquaculture methods.

Findings. The main hydrochemical parameters were found to be within piscicultural standards. Development of phyto-, zooplankton and zoobenthos on average for the season both in terms of quantity and biomass practically did not differ in both ponds.

When determining the efficiency of the use of ground amaranth seeds in the feeding of age-1+ carp during the growing season, an improvement in piscicultural parameters was found. In particular, the average weight of fish caught at the end of the growing season in the study group was $10.5 \%$, respectively, the fish productivity was 12.2\% higher than in the control, and the feed cost was $10.3 \%$ lower. Taking into account the cost of fish seeds and the cost of feed growing, an additional income 9.3\% was obtained.

It has been found that the addition of amaranth to the diet of female carp during pre-spawning retention positively affects the production of eggs, their fertilizing capacity, and the viability of larvae obtained. Accordingly, an increase in relative working fertility by $3.4 \%$, the percentage of fertilization of eggs by 3\%, and the yield of 3-day larvae by $6.7 \%$ in the experimental group were observed.

Originality. During the study, based on the analysis of the nutritional and biologically active properties of amaranth, for the first time its effect on the productive performance of age-1+ carp and the reproductive parameters of female carp was studied, as well as the effectiveness of its use in the diet.

Practical value. Finding feed components with high protein content and suitable for introduction in natural environment of Ukraine is topical and necessary to meet the needs of fish industry. Accordingly, the study of the efficiency of introducing amaranth into the diets of different age groups of carp will have a positive effect on growth, survival and reproductive performance, and will also reduce feed costs.

Key words: amaranth, carp, productivity, reproductive performance, feed costs, survival, efficiency. 


\title{
ПРОДУКТИВНЫЕ И РЕПРОДУКТИВНЫЕ ПОКАЗАТЕЛИ КАРПА ПРИ ВВЕДЕНИИ В СОСТАВ КОРМА АМАРАНТА
}

\author{
P. А. Паламарчук, feeding@if.org.ua, Институт рыбного хозяйства НАAН, г. Киев \\ О. В. Дерень, dereni@ukr.net, Институт рыбного хозяйства НАAН, г. Киев \\ C. А. Коба, koba sveta@i.ua, Институт рыбного хозяйства НАAН, г. Киев
}

Цель. Изучение влияния кормовой добавки амаранта на продуктивность $и$ экономическую составляющую при выращивании двухлеток карпа; а также на репродуктивные показатели самок карпа, исходя из анализа питательности амаранта и его биологически активных свойств.

Методика. Проведено два исследования, в рамках которых проанализировано влияние скармливания двухлеткам и самкам карпа зерна украинского высокоурожайного кормового сорта амаранта с биологически активными свойствами “Харьковский-1» на физиологические и продуктивные показатели. В кормления карпа использовали гранулированный комбикорм с содержанием протеина 23\%, в состав которого дополнительно вводили молотые семена амаранта методом гранулирования в количестве 10\% на замещение злаковой составляющей, предварительно подвергнув термической обработке. Рыбоводные, селекционные, гидрохимические и гидробиологические исследование проводили по общепринятым методикам.

Результаты. Установлено, что основные гидрохимические показатели находились $в$ пределах рыбоводных норм. Показатели развития фито-, зоопланктона и зообентоса в среднем за сезон как по количеству, так и по биомассе практически не отличались в обоих прудах.

При определении эффрективности применения семян амаранта в кормлении двухлеток карпа на протяжении всего сезона выращивания в составе сбалансированного комбикорма установлено улучшение рыбохозяйственных показателей. В частности, средняя масса выловленной рыбы в конце вегетационного периода в опытной группе была на 10,5\%, соответственно, рыбопродуктивность - на 12,2\% больше, чем в контроле, а затраты корма на выращивание - ниже на 10,3\%. Учитывая стоимость посадочного материала и потраченных на выращивание кормов, получено 9,3\% дополнительной прибыли при скармливании амаранта.

Определено, что добавление в рацион самок карпов амаранта в течение преднерестового содержания положительно влияло на продуцирование икры, ее оплодотворяемую способность, а также на жизнеспособность полученных личинок. Отмечено повышение относительной рабочей плодовитости на 3,4\%, оплодотворения икры на 3\%, и выхода 3-суточных личинок на 6,7\% в опытной группе.

Научная новизна. При проведении исследований, исходя из анализа питательности и биологически активных свойств амаранта, впервые изучено его влияние на продуктивные показатели двухлеток и способность к воспроизводству самок карпа, а также определена эффективность его использования в составе рациона.

Практическая значимость. Поиск кормовых компонентов с высоким содержанием протеина, пригодных для интродукции в естественных условиях нашей страны является актуальным и необходимым для обеспечения потребностей рыбохозяйственной отрасли. Согласно исследованию, введения амаранта в состав рациона разновозрастных групп карпа окажет положительное влияние на прирост, выживаемость и репродуктивные показатели, а также позволит уменьшить кормовой коэффициент.

Ключевые слова: амарант, карп, продуктивность, репродуктивные показатели, затраты корма, выживаемость, эффективность. 


\section{ПОСТАНОВКА ПРОБЛЕМИ ТА АНАЛІЗ ОСТАННІХ ДОСЛІДЖЕНЬ І ПУБЛІКАЦІЙ}

Інтенсифікація виробництва, застосування прогресивних технологій та впровадження економічно обгрунтованих рішень у процесі виробництва продукції тваринництва $€$ невід'ємною складовою забезпечення зростання сільськогосподарського виробництва відповідно до потреб населення. Реалізація цього завдання безпосередньо залежить від повноцінної годівлі тварин.

Особливо гострою проблемою в умовах сьогодення $\epsilon$ забезпечення введення до складу раціону якісних високобілкових кормових компонентів. Нестача вмісту протеїну в кормі призводить до зниження продуктивних та репродуктивних показників, що, в свою чергу, збільшує витрати кормів. Крім того, це є причиною зниження якості та збільшення собівартості отриманої продукції. Відповідно, перспективним та актуальним є пошук нетрадиційних кормових компонентів, які за поживністю та перетравністю можуть забезпечити потреби в поживних речовинах та оптимальний функціональний стан організму тварин, що здатні підвищувати продуктивність, стимулювати відтворну здатність та покращувати споживчі характеристики продукції $[1,2]$.

В рибництві балансування раціону за вмістом протеїну традиційно здійснювали, використовуючи кормові компоненти тваринного походження перш за все, рибне та м'ясо-кісткове борошно. На сьогоднішній день є величезний дефіцит даних компонентів, а, враховуючи, що за прогнозами ООН до 2026 р. обсяги виробництва рибної продукції збільшаться на 32\%, їх нестача, а, відповідно, і вартість будуть зростати [3]. В Україні основним об'єктом аквакультури є короп. Відповідно до економічної доцільності та фізіологічних потреб, у складі раціонів для різновікових груп коропа основою $є$ злакова складова. В якості джерела протеїну широко використовують бобові та продукти їх переробки [4]. Проте, їх введення до складу раціонів є обмеженим, з огляду на вміст низки речовин, що перешкоджають травленню [5].

Слід також зазначити, що питання культивування та використання альтернативних кормових культур з високим вмістом білка і пристосованих до умов регіону залишається актуальним і перспективним в усьому світі [6]. В Україні у зв'язку зі змінами клімату зменшуються площі земель, придатних для вирощування традиційних кормових культур. Тому адаптувати галузь можна шляхом збільшення в структурі посівних площ частки посухостійких сільськогосподарських культур [7].

Однією 3 таких добавок $є$ амарант (Amaranthus) - високобілкова, посухостійка, високопродуктивна рослина з біологічно активними властивостями. Наразі не дуже поширена, бо недостатньо вивчено способи іiі культивування та переробки, а, відповідно, використання в годівлі тварин [8].

Технології переробки дозволяють використовувати не лише зелену масу i силос з амаранта, а й олію, борошно з насіння і макуху, продукти екстрагування [9].

\section{ВИДІЛЕННЯ НЕВИРІШЕНИХ РАНІШЕ ЧАСТИН ЗАГАЛЬНОЇ ПРОБЛЕМИ. МЕТА РОБОТИ}

Вміст білка у зерні амаранта вищий, ніж у кукурудзі, ячмені, пшениці та сорго. В ньому велика кількість амінокислот, вітамінів і мікроелементів. За 
вмістом лізину, триптофану, аргініну, метіоніну і фенілаланіну амарант переважає практично всі відомі зернобобові культури. Особливо слід відзначити значний вміст лізину (в 30 разів вищий, ніж у пшеничному зерні), що безпосередньо сприяє кращому засвоєнню поживних речовин корму [10].

Саме тому, при введенні до складу кормів для різних видів тварин, амарант чинить протизапальну, протипаразитарну, противірусну, регенераційну дії, а також позитивно впливає на ріст, продуктивність, рівень виживання і якість отриманої продукції [11]. Відомі дослідження про позитивний вплив як зеленої маси, так і зерна амаранта на продуктивність племінних курей-несучок та бройлерів, свиней і телят [12-16]. Також є літературні дані щодо позитивного впливу згодовування борошна 3 насіння амаранта на приріст маси і відсоток виходу з вирощування канального сома [17].

Відповідно до біологічних властивостей амаранта, нами попередньо визначено норми введення та отримано результати його впливу на фізіологобіохімічні показники організму коропа. Встановлено, що згодовування меленого насіння та олії амаранта в складі основного раціону дволіток коропа сприяє покращенню фізіологічного стану організму риб, збільшенню темпів росту та зменшенню витрат кормів на вирощування [18-20].

В основі прикладної оцінки та аналізу ефективності оптимізації раціону є засвоєння поживних речовин з мінімальними витратами на корм. У зв'язку з цим, виникла необхідність вивчення впливу згодовування амаранта на продуктивні та репродуктивні показники коропа.

Отже, питання проведення додаткових наукових експериментальних досліджень в даному напрямі є актуальним і має перспективу.

Метою дослідження було вивчення впливу кормової добавки амаранту на особливості росту, розвитку, ефективність використання кормів та економічну складову при вирощуванні дворічок коропа; а також на репродуктивні показники самиць коропа, виходячи 3 аналізу його поживності та біологічно активних властивостей.

\section{МАТЕРІАЛИ ТА МЕТОДИ}

Дослідження проведено в ДП ДГ «Нивка» Інституту рибного господарства НААН. Проведено серію експериментальних модельних випробувань в умовах ставів 3 визначення ефективності введення до складу раціону дворічок та самиць коропа амаранта, дотримуючись загальноприйнятих у рибництві правил постановки дослідів. Дослідження проведено в межах двох окремих експериментів.

Проаналізовано вплив згодовування дволіткам та самицям коропа зерна українського високоврожайного кормового сорту амаранта 3 біологічно активними властивостями «Харківський-1». Перед введенням до складу корму амарант перемелювали та піддавали термічній обробці за температури $120^{\circ} \mathrm{C}$. В годівлі коропа використовували гранульований комбікорм із вмістом протеїну на рівні $23 \%$, до складу якого додатково вводили амарант методом гранулювання. Добова кількість комбікорму становила 3-5\% від маси риб. 
Об'єктом у першому експерименті були дволітки нивківського лускатого коропа. Сформовано контрольну і дослідну групи риб, останнім додатково до складу основного раціону введено мелене насіння амаранту відповідно в кількості $10 \%$. Комбікорм згодовували рибам один раз на добу впродовж 95 днів. Вивчали вплив амаранту на рибницькі показники і витрати кормів на вирощування. При цьому забезпечували аналогічні оптимальні умови утримання та контролювали гідрохімічний та гідробіологічний режими у ставах.

Завданням другого експерименту було визначення впливу згодовування амаранту в кількості $10 \%$ в складі основного раціону самиць коропа у переднерестовий період на їх репродуктивні показники та життєстійкість отриманих нащадків. Комбікорм згодовували самицям один раз на добу впродовж 18 днів.

Відбір проб для хімічного аналізу води та їхню обробку в лабораторії проводили за загальноприйнятими методиками [21]. Якість води оцінювали згідно із загальними вимогами та нормами у рибництві [22].

Відбір та обробку гідробіологічних проб проводили за загальноприйнятими методиками [23 - 25].

Контрольні лови дволіток коропа проводили двічі на місяць. При цьому здійснювали контрольні зважування і огляд зовнішнього покриву та внутрішніх органів риб. Годівлю коропа проводили за схемами нормованої годівлі. Після закінчення досліду визначали відсоток виходу риби з вирощування, іiі загальну і середню масу [26]. Коефіцієнт вгодованості розраховували за Фультоном [27].

Селекційні методики застосовували 3 дотриманням інструкцій ведення селекційно-племінної справи зі ставовими рибами. При відборі селекційного матеріалу його оцінювали за рибогосподарськими показниками. Штучне відтворення здійснювали в умовах інкубаційного цеху за загальноприйнятими методиками [28]. Початкову i кінцеву масу ікри, темпи росту личинок обчислювали за методиками, описаними I. I. Шмальгаузеном та I. Ф. Правдіним [29]. 3 метою аналізу репродуктивних характеристик самиць було відібрано проби незаплідненої ікри, які досліджували в лабораторних умовах. Ікру фіксували 4\%вим розчином формаліну. Відбір ікри від самиць здійснювали методом зціджування. Загальну масу одержаної ікри визначали ваговим способом 3 використанням електронних терезів третього класу точності.

Одержані цифрові результати опрацьовували статистично за допомогою стандартного пакету статистичних програм «Microsoft EXCEL». Вираховували середні арифметичні величини (M), середню квадратичну помилку (m) i вірогідність різниць (Р) між досліджуваними середньоарифметичними величинами [30].

\section{РЕЗУЛЬТАТИ ДОСЛІДЖЕНЬ ТА ЇХ ОБГОВОРЕННЯ}

При вирощуванні дволіток коропа за згодовування амаранта в умовах ставів упродовж вегетаційного періоду проводили контроль хімічного складу води у дослідних ставах.

Загалом, не відмічено певної закономірності в змінах хімічного складу води залежно від складу кормів, які використовувалися в годівлі риби. Середовище, де 
вирощувалась риба, було слаболужним, значення $\mathrm{pH}$ коливалось від 7,0 до 7,9, що вказує на оптимальне середовище для проходження біохімічних процесів в організмі дослідних груп риб. Кількість легкоокиснюваних органічних сполук, яка визначається за показником перманганатного окиснення, утримувалась за сезон в межах 14,2-18,7 мгО/дм³, що відповідає незначному забрудненню водойми і дещо перевищує нормативні значення. Біогенні елементи (азот в різних формах, фосфор) у воді знаходились у межах нормативних значень в обох ставах. Концентрація амонійного азоту в кінці вирощування зросла до 1,88 мг $\mathrm{N} /$ дм $^{3}$ в контролі і до 1,04 мг N/дм³ в досліді. Твердість води була помірною. Вміст солей кальцію та натрію в максимальних значеннях дещо перевищував рибницькі норми і в середньому складав відповідно 56,8-60,1 та 43,5-56,7 мг/дм². Така ж закономірність прослідковувалася і за кількістю хлоридів, яка в середньому за сезон переважала рибницькі нормативи і становила 85,7-94,5 мг/дм³. За період вирощування мінералізація води в обох ставах була в межах рибницьких норм.

Упродовж періоду вирощування досліджували динаміку розвитку фітопланктону, зоопланктону та зообентосу експериментальних ставів.

Для динаміки кількісного розвитку фітопланктону було характерним зростанням показників упродовж літа 3 максимальним їх значенням в серпні. Чисельність фітопланктону двох дослідних ставів за період дослідження коливалась у межах від 15,48 до 163,95 млн. кл./дм³. За середньосезонними показниками найбільш численними $(80,9-83,7 \%)$ були синьо-зелені водорості, друге місце посідали зелені (13,7-15,03\%). Біомаса фітопланктону за період дослідження в експериментальних ставах знаходилась у межах від 4,37 до 14,45 мг/дм ${ }^{3}, \quad 3$ середньосезонними показниками на рівні 9,67-9,88 мг/дм ${ }^{3}$. Домінуючими, як за чисельністю, так і за біомасою, були види родів Microcyctis, Scenedesmus, Dictyosphaerium, Chlamydomonas. Середньосезонні показники фітопланктону як за чисельністю, так i за біомасою були практично на однаковому рівні (табл. 1).

Таблиия 1. Динаміка розвитку фітопланктону у вирощувальних ставах, млн. кл./дм $\mathbf{3}^{3}$ мг/дм ${ }^{3}$

Table 1. Dynamics of phytoplankton development in growing ponds, mln cl / $\mathbf{d m}^{3} / \mathbf{m g} / \mathbf{d m}^{3}$

\begin{tabular}{||c|c|c|c|c||}
\hline \multirow{2}{*}{ Група риб / Group of fish } & \multicolumn{3}{|c||}{$\begin{array}{c}\text { Період вегетаційного сезону, місяць / } \\
\text { Season of the growing, month }\end{array}$} & \multirow{2}{*}{$\begin{array}{c}\text { Середнє значення / } \\
\text { Average value }\end{array}$} \\
\cline { 2 - 4 } & VI & VII & VIII & \\
\hline \multirow{2}{*}{ Контроль / Control } & $\underline{23,520}$ & $\underline{95,322}$ & $\underline{106,301}$ & $\underline{75,047}$ \\
Дослід / Experiment & 4,37 & 14,45 & 10,82 & 9,88 \\
& $\underline{41,764}$ & $\underline{15,480}$ & $\underline{163,95}$ & $\underline{73,730}$ \\
\hline \hline
\end{tabular}

Зоопланктон експериментальних ставів упродовж сезону вирощування коропа був представлений організмами, які відносяться до трьох систематичних груп: тип нижчі черви Rotifera, ракоподібні підряду Cladocera та ряду Copepoda. В липні та серпні спостерігалося підвищення кількісного розвитку тваринного планктону за рахунок веслоногих ракоподібних (родина Cyclopidae). Показники розвитку зоопланктону впродовж вегетаційного сезону у контрольному ставу 


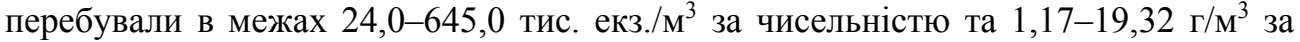

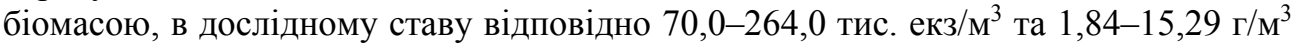
(табл. 2). В цілому, розвиток зоопланктону був оптимальним і за якісним складом придатним для споживання коропом.

Таблиия 2. Динаміка розвитку зоопланктону у вирощувальних ставах, тис. екз./ $/ \mathbf{m}^{3} / \mathbf{r} / \mathbf{M}^{3}$

Table 2. Dynamics of development of zooplankton in growing ponds, thousand units $/ \mathbf{m}^{3} / \mathbf{g} / \mathbf{m}^{3}$

\begin{tabular}{||c|c|c|c|c||}
\hline \multirow{2}{*}{$\begin{array}{c}\text { Група риб / } \\
\text { Group of fish }\end{array}$} & \multicolumn{2}{|c|}{$\begin{array}{r}\text { Період вегетаційного сезону, місяць / } \\
\text { Season of the growing, month }\end{array}$} & $\begin{array}{c}\text { Середнє значення / } \\
\text { Average value }\end{array}$ \\
\cline { 2 - 4 } & VI & VII & VIII & \multicolumn{1}{||}{} \\
\hline \multirow{2}{*}{ Контроль / Control } & 24,0 & 360,0 & 645,0 & 343,0 \\
& 1,17 & 16,09 & 19,32 & 12,20 \\
Дослід / Experiment & 70,0 & 264,0 & 228,0 & 187,3 \\
\hline
\end{tabular}

Донна фауна вирощувальних ставів якісно була представлена в основному личинками хірономід 3 найбільшими показниками в червні (1,67-4,93 г/ $\mathrm{m}^{2}$ за біомасою та 100,0-865,8 екз./ $\mathrm{M}^{2}$ за чисельністю). Починаючи 3 другої половини липня, відбулося активне виїдання личинок хірономід рибою, і вже в кінці серпня у виїмках грунту бентофауна була відсутня.

У результаті проведених досліджень встановлено, що середня маса коропів дослідної групи, якій згодовували амарант, при вилові зросла на $11,8 \%$ i становила 190,0 2,72 г в дослідному ставу, проти $170,0 \pm 2,98$ г у контролі (табл. 3). Коефіцієнт вгодованості риб за Фультоном у контрольній групі становив 2,3, а в дослідній - 3,1, що відповідає нормативним значенням.

Табличя 3. Характеристика розмірно-вагових показників однорічок коропа за додавання до основного раціону амаранта $(\mathbf{M} \pm \mathbf{m}, \mathbf{n}=10)$

Table 3. Characterization of the size and weight indices of carp perennials for addition to the basic diet of amaranth $(M \pm m, n=10)$

\begin{tabular}{||c|c|c|c|c|c|c||}
\hline $\begin{array}{c}\text { Група риб / } \\
\text { Group of fish }\end{array}$ & $\mathbf{m}$ & $\mathbf{L}$ & $\mathbf{~}$ & $\mathbf{H}$ & $\mathbf{~}$ & Kv \\
\hline Контроль / Control & $170,0 \pm 2,98$ & $23,6 \pm 0,86$ & $19,4 \pm 0,73$ & $7,1 \pm 0,29$ & $15,4 \pm 0,62$ & 2,3 \\
Дослід / Experiment & $190,0 \pm 2,72$ & $22,1 \pm 1,10$ & $18,3 \pm 0,95$ & $6,6 \pm 0,31$ & $14,9 \pm 0,59$ & 3,1 \\
\hline
\end{tabular}

Середня маса виловленої риби у кінці вегетаційного періоду в дослідній групі була на $10,5 \%$ більшою ніж у контролі. Відповідно, рибопродуктивність дослідного ставу була на 12,2\% вищою. Витрати корму при згодовуванні амаранта знизились на 10,3\% (табл. 4).

Вартість корму, витраченого на вирощування коропа, була вищою при застосуванні в годівлі 10\% амаранта впродовж всього сезону вирощування, проте економічна ефективність зросла за рахунок зменшення витрат корму на кілограм приросту і збільшення середньої маси риб (табл. 5). 
Таблиця 4. Результати вирощування дволіток коропа 3 додаванням до основного раціону амаранта

Table 4. The results of growing two-year-old carp with the addition of basic amaranth diet

\begin{tabular}{||l|c|c||}
\hline \multicolumn{1}{|c|}{ Група риб / Group of fish } & $\begin{array}{c}\text { Контроль / } \\
\text { Control }\end{array}$ & $\begin{array}{c}\text { Дослід / } \\
\text { Experiment }\end{array}$ \\
\hline Посаджено на вирощування, кг / Planted for cultivation, kg & 60 & 60 \\
Посаджено на вирощування, екз. / Planted for cultivation, copy & 2610 & 2608 \\
Середня маса, г / Average mass, g & 23 & 23 \\
Виловлено, екз. / Caught, copy & 2217 & 2226 \\
Вихід, \% / Entrance, \% & 84,9 & 85,4 \\
Середня маса, г / Average mass, g & 170 & 190 \\
Загальна маса, кг / Total weight, kg & 377 & 423 \\
Рибопродуктивність, кг/га / Fish productivity, kg/ha & 1885 & 2115 \\
Згодовано корму, кг / Feeding, kg & 1079 & 1079 \\
Витрати корму, кг/кг приросту / Feed costs, kg/kg gain & 2,9 & 2,6 \\
\hline
\end{tabular}

Табличя 5. Економічна ефективність застосування амаранта в складі основного раціону дворічок коропа в умовах промислового виробництва

Table 5. The economic efficiency of the use of amaranth in the basic diet of carp yards in the conditions of industrial production

\begin{tabular}{|c|c|c|}
\hline Група риб / Group of fish & $\begin{array}{l}\text { Контроль / } \\
\text { Control }\end{array}$ & $\begin{array}{l}\text { Дослід / } \\
\text { Experiment }\end{array}$ \\
\hline Площа ставу, га / Pond area, ha & 0,2 & 0,2 \\
\hline Вирощено коропа, кг / Carp grown, kg & 377 & 423 \\
\hline Витрати на корм, комбікорм / compound feed & 2698 & 2428 \\
\hline $\begin{array}{l}\text { грн * / Cost of feed, амарант / amaranth } \\
\text { UAH }\end{array}$ & & 864 \\
\hline Bcboro / total & 2698 & 3292 \\
\hline $\begin{array}{l}\text { Витрати корму на } 1 \text { кг вирощеної продукції, грн / Feed costs per } 1 \\
\text { kg. grown products, UAH }\end{array}$ & 7,16 & 7,78 \\
\hline $\begin{array}{l}\text { Витрати на посадковий матеріал, грн * / Costs of planting material, } \\
\text { UAH }\end{array}$ & 1200 & 1200 \\
\hline Ринкова вартість, 1 кг риби / 1 kg of fish & 26 & 26 \\
\hline $\begin{array}{l}\text { грн / Market value, вирощеної продукції / grown products } \\
\text { UAH }\end{array}$ & 9802 & 10998 \\
\hline $\begin{array}{l}\text { Прибуток (враховуючи витрати на корми і посадковий матеріал), } \\
\text { грн/га / Profit (including feed and planting costs), UAH / ha }\end{array}$ & 29520 & 32530 \\
\hline $\begin{array}{l}\text { Прибуток (враховуючи витрати на корми і посадковий матеріал), } \\
\text { \% / Profit (including feed and planting costs),\% }\end{array}$ & & $+9,3 \%$ \\
\hline
\end{tabular}

Примітка. * - ціна комбікорму - 2,5 грн/кг, амаранта - 8 грн/кг; посадкового матеріалу - 20 грн/кг. 
Нижчі витрати на вирощування кілограма рибної продукції отримано в контрольній групі - 7,16 грн, що на 8\% менше, ніж при згодовуванні в складі основного раціону амаранта в кількості 10\%. Проте, за згодовування амаранта отримано додаткові прирости дворічок коропа, що позитивно вплинуло рибопродуктивність дослідного ставу.

Враховуючи вартість посадкового матеріалу і витрачених на вирощування кормів, отримуємо прибуток від вирощування коропа для дослідної групи 32530 грн./га, що більше на 9,3\%, ніж у контролі.

Таким чином, розробка і впровадження поставленого завдання забезпечує можливість підвищення рибопродуктивності ставів за рахунок згодовування штучних кормів покращеного складу. Це дозволяє знизити витрати штучних кормів і отримати вищі прирости при вирощуванні, поліпшити фізіологічні показники коропа.

Проаналізовано вплив амаранта на репродуктивні показники дослідних груп риб у порівнянні з контрольними, зокрема на якісні показники ікри, відносну і робочу плодючість, відсоток виживання та вихід личинок з ікри.

В експерименті за згодовування амаранта використано самиць-аналогів за розмірно-ваговими характеристиками (табл. 6).

Таблиия 6. Розмірно-вагові характеристики експериментальних груп самиць лускатого коропа нивківського внутрішньопородного типу $(\mathbf{M} \pm \mathbf{m}, \mathbf{n}=\mathbf{3})$

Table 6. Dimensional and weight characteristics of experimental groups of females of the scaly carp of the Nivkovian intra-breed type $(M \pm m, n=3)$

\begin{tabular}{|l|c|c|}
\hline \multicolumn{1}{|c|}{ Показник / Indicator } & Контроль / Control & Дослід / Experiment \\
\hline $\mathrm{m}, \mathrm{r}$ & $5500,0 \pm 353,58$ & $5157,5 \pm 196,31$ \\
I, CM & $62,67 \pm 1,11$ & $60,75 \pm 0,86$ \\
L, CM & $66,8 \pm 1,34$ & $65,0 \pm 1,00$ \\
$\mathrm{H}, \mathrm{CM}$ & $20,5 \pm 0,33$ & $20,2 \pm 0,22$ \\
$\mathrm{O}, \mathrm{cM}$ & $47,9 \pm 0,55$ & $46,9 \pm 0,28$ \\
$\mathrm{C}, \mathrm{CM}$ & $16,0 \pm 0,42$ & $15,3 \pm 0,21$ \\
KV & $2,2 \pm 0,05$ & $2,3 \pm 0,08$ \\
I/H & $3,1 \pm 0,02$ & $3,0 \pm 0,02$ \\
I/O & $1,3 \pm 0,02$ & $1,3 \pm 0,02$ \\
I/C & $3,9 \pm 0,06$ & $3,9 \pm 0,04$ \\
\hline
\end{tabular}

В результаті проведених встановлено, що згодовування амаранта в переднерестовий період позитивно впливає на репродуктивну функцію самиць коропа, про що свідчить підвищення у них відносної робочої плодючості на 3,4\%. Відсоток запліднення ікри в контролі складав 76,3\%, в досліді - 79,3\%, що на 3\% більше. Вихід 3-добових личинок був більшим на 6,7\% в дослідній групі (табл. 7).

Згідно з біологічними характеристиками, досліджено вплив згодовування амаранта в кількості 10\% в складі основного раціону самиць коропа впродовж усього переднерестового періоду на їхні репродуктивні показники i життєстійкість отриманих нащадків. 
Таблиця 7. Репродуктивні показники самиць лускатого коропа нивківського внутрішньопородного типу за згодовування амаранта в переднерестовий період $(\mathrm{M} \pm \mathrm{m}, \mathbf{n}=\mathbf{3})$

Table 7. Reproductive indices of females scaly of carp of the Nivkovsky intrabreed type for feeding amaranth in the before spawning period $(M \pm m, n=3)$

\begin{tabular}{|c|c|c|}
\hline Показник / Indicator & Контроль / Control & $\begin{array}{l}\text { Дослід / } \\
\text { Experiment }\end{array}$ \\
\hline Маса ікри, г / Weight of caviar, g & $903,3 \pm 59,53$ & $945,0 \pm 73,05$ \\
\hline $\begin{array}{l}\text { Робоча плодючість, тис. ікр. / Labor fertility, thousand } \\
\text { eggs }\end{array}$ & $774360 \pm 30858,90$ & $775805 \pm 67497,86$ \\
\hline $\begin{array}{l}\text { Відносна плодючість, тис. ікр. / кг / The relative } \\
\text { fertility, thousand eggs / kg }\end{array}$ & $165,5 \pm 9,72$ & $171,3 \pm 13,34$ \\
\hline Запліднення ікри, \% / Fertilization of eggs,\% & 76,3 & 79,3 \\
\hline $\begin{array}{l}\text { Вихід 3-добових личинок, млн екз. / Output of 3-day } \\
\text { larvae, mln. сору }\end{array}$ & 1,4 & 1,5 \\
\hline
\end{tabular}

\section{ВИСНОВКИ ТА ПЕРСПЕКТИВИ ПОДАЛЬШОГО РОЗВИТКУ}

Визначено продуктивні та відтворні показники коропа за введення до складу раціону кормової добавки з біологічно активними властивостями - меленого насіння амаранта.

Встановлено, що основні гідрохімічні показники знаходились в межах рибницьких норм. Показники розвитку фіто-, зоопланктону та зообентосу в середньому за сезон за кількістю і біомасою були на задовільному рівні для забезпечення коропа природним кормом і практично не відрізнялися в обох ставах.

При застосуванні меленого насіння амаранта в годівлі дворічок коропа впродовж всього сезону вирощування в складі збалансовано комбікорму встановлено, що середня маса виловленої риби у кінці вегетаційного періоду у дослідній групі була на 10,5\% більшою, ніж у контролі. Коефіцієнт вгодованості риб у контрольній групі становив 2,3, а у дослідній - 3,1. Відповідно, рибопродуктивність дослідного ставу була вищою на 12,2\%.

Витрати корму при згодовуванні амаранта були нижчими на 10,3\%, проте витрати на вирощування рибної продукції - вищими на 8\%. Враховуючи вартість посадкового матеріалу і витрачених на вирощування кормів, отримано прибуток від вирощування коропа для дослідної групи на рівні 32530 грн/га, що на 9,3\% більше, ніж у контролі.

Згодовування амаранта в переднерестовий період позитивно вплинуло на репродуктивну функцію самок коропа, про що свідчить підвищення відносної робочої плодючості на 3,4\%. Відсоток запліднення ікри в контролі склав 76,3\%, в дослідній групі - 79,3\%, що на 3\% більше. Вихід 3-добових личинок був більшим на $6,7 \%$ в дослідній групі.

Отже, важливо забезпечити збалансовану нормовану годівлю риб на усіх етапах онтогенезу, зокрема племінного матеріалу, оскільки це безпосередньо впливає на якість отриманих нащадків. При цьому слід використовувати кормові компоненти, що відповідають фізіологічним потребам організму риб та забезпечують отримання якісної економічно конкурентоздатної продукції. 


\section{ЛІТЕРАТУРА}

1. Review of the feed industry from a historical perspective and implications for its future / Coffey D. et al. // Journal of Applied Animal Nutrition. 2016. № 4. URL: https://www.cambridge.org/core/journals/journal-of-applied-animalnutrition/article/review-of-the-feed-industry-from-a-historical-perspective-andimplications-for-its-future/ A655939BDBB386140F15ECB577F5711C.

2. Научно-обоснованные нормы кормления сельскохозяйственных животных : краткий курс лекций / сост. А. П. Коробов, С. П. Москаленко. Саратов : Саратовский ГАУ, 2014. 50 с.

3. Nemo L. Faux fish might help aquaculture keep feeding the world // Scientific American. 2019. № 6. URL: https://www.scientificamerican.com/article/faux-fishmight-help-aquaculture-keep-feeding-the-world.

4. Желтов Ю. А. Рациональное кормление карповых рыб в аквакультуре. Киев : Инкос, 2008. 408 c.

5. Mavromichalis I. 6 alternative protein sources to soybean meal // Feed strategy. 2018. Vol. 69 (2). P. 10-15.

6. Protein sources for the animal feed industry: Expert consultation and workshop, 29 april - 3 may 2002. Bangkok, 2002. URL: http://www.fao.org/3/y5019e03.htm.

7. Кліматичні зміни та сільське господарство. Виклики для аграрної науки та освіти : II Міжнар. наук.-практ. конф., 10-12 квіт. 2019 р. : збірник тез. Київ Миколаїв - Херсон : Агроосвіта, 2019. 490 с.

8. Шилов В.Н. Научное обоснование и технологические основы повышения продуктивности животных при использовании амаранта в качестве корма и биологически активной добавки : автореф. дисс. на соискание уч. степени докт. с.-х. наук : спец. 06.02 .08 «Кормопроизводство, кормление сельскохозяйственных животных и технология кормов». Саранск, 2015. 46 с.

9. Гальцев В. П., Строцький П. І., Сєнік В. Б. Огляд застосування амаранту та один зі способів отримання амарантової олії як джерела сквалену // Аграрний вісник Причорномор'я. 2012. Вип. 63. С. 188-191.

10. Карунський О. Й., Стрілець А. В. Хімічний та амінокислотний склад амаранту // Вісник державного агроекологічного університету. 2008. № 2 (23). С. 190192.

11. Карасьова Н. В. Перспективи використання амаранту // Хранение и переработка зерна. 2009. № 1. С. 31-33.

12. Рядчиков В., Омаров М., Полежаев С. Идеальный белок в рационах свиней и птицы // Животноводство России. 2010. № 2. С. 49-51.

13. Гіска В.В. Використання екструдованого насіння амаранту в складі комбікормів для молодняку свиней : автореф. дис. на здобуття наук. ступеня канд. с.-г. наук : спец. 06.02.02 «Годівля тварин та технологія кормів». Харків, 2002. $21 \mathrm{c}$.

14. Рубцовое пищеварение у коров получавших силос из амаранта / В. Н. Шилов и др. // Ветеринарный врач. 2008. № 1. С. 30-33.

15. Effect of feedinq amaranth on growth efficiency and health of market pigs / $\mathrm{Zral}^{-} \mathrm{Z}$. et. al. // Acta Vet. Brno. 2004. Vol. 73. P. 437-444.

16. The use of amaranth (genus Amaranthus L.) in the diets for broiler chickens / B. Pisarikova et. al. // Veterinarni Medicina. 2006. № 51 (7). Р. 399- 407.

17. Бескровная С. И., Дуда Ю. В., Рожков В. В. Опыт применения муки из семян амаранта в составе комбикорма для рыб // Стан та перспективи використання 
водного бассейну Поділля: промислові, екологічні, туристичні аспекти : Міжнар. наук.-практ. конф. : матер. конф. Кам'янець-Подільський, 2010. С. 5-6.

18. Паламарчук Р. А., Дерень О. В., Качай Г. В. Вплив згодовування амаранту (Amaranthus) на рибницькі та деякі фізіолого-біохімічні показники дволіток коропа // Рибогосподарська наука України. 2016. № 2. С. $73-81$.

19. Паламарчук Р. А., Дерень О.В. Визначення ефективності використання амаранту (Amaranthus) в годівлі коропа за різних умов вирощування // Рибогосподарська наука України. 2018. № 2. С. 103-115.

20. Паламарчук Р. А., Дерень О. В. Вплив амаранту Amaranthus (Linnaeus) на якісні та продуктивні характеристики дволіток коропа Cyprinus carpio (Linnaeus) за введення його до складу раціону // Рибогосподарська наука України. 2018. № 3. С. 89-102.

21. Алекин О. А. Основы гидрохимии. Ленинград : Гидрометеоиздат, 1970. 412 с.

22. СОУ-05.01.-37-385:2006. Вода рибогосподарських підприємств. Загальні вимоги та норми. Київ : Мін-во аграрної політики України, 2006. 15 с. (Стандарт Мінагрополітики України).

23. Кражан С. А., Хижняк М. І. Природна кормова база рибогосподарьких водойм : навчальний посібник. Київ : Аграрна освіта, 2014. 333 с.

24. Методи гідроекологічних досліджень поверхневих вод / Арсан О. М. та їн.; ред. В. Д. Романенка. Київ : Логос, 2006. 408 с.

25. Определитель пресноводных беспозвоночных Европейской части СССР (планктон и бентос) / ред. Л. А. Кутикова, Я. И. Старобогатов. Ленинград : Гидрометеоиздат, 1977. $512 \mathrm{c.}$

26. Желтов Ю. О. Методичні вказівки 3 проведення дослідів по годівлі риб // Рибне господарство. 2003. Вип. 62. С. 23-28.

27. Инструкция по физиолого-биохимическим анализам рыбы / Лиманский В. В. и др. Москва : ВНИИПРХ, 1984. 59 с.

28. Киселев И. В. Биологические основы осеменения и инкубации клейких яиц карповых рыб. Киев : Наукова думка, 1980. 293 с.

29. Томиленко В. Г., Олексієнко О. О., Кучеренко А. П. Інструкція з організації племінної роботи в коропівництві України // Інтенсивне рибництво. Київ : Аграрна наука, 1995. С. 3-33.

30. Плохинский Н. А. Биометрия. Москва : Московский университет, 1981. 367 с.

\section{REFERENCES}

1. Coffey, D., Dawson, K., Ferket, P., \& Connolly, A. (2016). Review of the feed industry from a historical perspective and implications for its future. Journal of Applied Animal Nutrition, 4. cambridge.org. Retrived from https://www.cambridge.org/core/journals/journal-of-applied-animalnutrition/article/review-of-the-feed-industry-from-a-historical-perspective-andimplications-for-its-future/A655939BDBB386140F15ECB577F5711C.

2. Korobov, A. P., \& Moskalenko, S. P. (Comp.). (2014). Nauchno-obosnovannye normy kormleniya sel'skokhozyaystvennykh zhivotnykh: kratkiy kurs lektsiy. Saratov: Saratovskiy GAU.

3. Nemo, L. (2019). Faux fish might help aquaculture keep feeding the world. Scientific American, 6. scientificamerican.com. Retrived from 
https://www.scientificamerican.com

/article/faux-fish-might-help-aquaculturekeep-feeding-the-world.

4. Zheltov, Yu. A. (2008). Ratsionalnoe kormlenie karpovykh ryb v akvakulture. Kyiv: Inkos.

5. Mavromichalis, I. (2018). 6 alternative protein sources to soybean meal. Feed strategy, 69 (2), 10-15.

6. Protein sources for the animal feed industry: Expert consultation and workshop. (2002). Bangkok. Retrived from http://www.fao.org/3/y5019e03.htm.

7. Klimatychni zminy ta silske hospodarstvo. Vyklyky dlia ahrarnoi nauky ta osvity: II Mizhnar. nauk.-prakt. konf. (2019). Kyiv - Mykolaiv - Kherson.

8. Shilov, V. N. (2015). Nauchnoe obosnovanie i tekhnologicheskie osnovy povysheniya produktivnosti zhivotnykh pri ispol'zovanii amaranta $\mathrm{v}$ kachestve korma i biologicheski aktivnoy dobavki. Exstended abstract of doctor's thesis. Saransk.

9. Haltsev, V. P., Stotskyi, P. I., \& Sienik, V. B. (2012). Ohliad zastosuvannia amarantu ta odyn zi sposobiv otrymannia amarantovoi olii, yak dzherela skvalenu. Ahrarnyi visnyk Prychornomoria, 63, 188-191.

10. Karunskyi, O. Y., \& Strilets, A. V. (2008). Khimichnyi ta aminokyslotnyi sklad amarantu. Visnyk derzhavnoho ahroekolohichnoho universytetu, 2 (23), 190-192.

11. Karasova, N. V. (2009). Perspektyvy vykorystannia amarantu. Khranenye y pererabotka zerna, 1, 31-33.

12. Ryadchikov, V., Omarov, M., \& Polezhaev, S. (2010). Ideal'nyy belok v ratsionakh sviney i ptitsy. Zhivotnovodstvo Rossii, 2, 49-51.

13. Hiska, V. V. (2002). Vykorystannia ekstrudovanoho nasinnia amarantu v skladi kombikormiv dlia molodniaku svynei. Exstended abstruct of candidate's thesis. Kharkiv.

14. Shilov, V. N., Tamimdarov, B. F., Sergeeva, G. Kh., Khirug, S. S., Zharkovskiy, A. P., Mad'yarov, N. A., Nizamutdinov, I. A., \& Kekhaberidze, I. B. (2008). Rubtsovoe pishchevarenie u korov poluchavshikh silos iz amaranta. Veterinarnyy vrach, 1, 30-33.

15. Zral־, Z., Písafiíková, B., Hudcová, H., Trãková, M, \& Herzig, I. (2004). Effect of feedinq amaranth on growth efficiency and health of market pigs. Acta Vet Brno, 73, 437-444.

16. Pisarikova, B., Lraly, L., Kracmar, S., Trckova, M., \& Herzig, I. (2006). The use of amaranth (genus Amaranthus L.) in the diets for broiler chickens. Veterinarni Medicina, 51 (7), 399-407.

17. Beskrovnaya, S. I., Duda, Yu. V., \& Rozhkov, V. V. (2010). Opyt primeneniya muki iz semyan amaranta v sostave kombikorma dlya ryb. Stan ta perspektivi vikoristannya vodnogo basseynu Podillya: promislovi, ekologichni, turistichni aspekti: Mizhnarodna nauk.-praktych. konf. Kam'yanets'-Podil's'kiy, 5-6.

18. Palamarchuk, R. A., Deren, O. V., \& Kachai, H. V. (2016). Vplyv zghodovuvannia amarantu (Amaranthus) na rybnytski ta deiaki fizioloho-biokhimichni pokaznyky dvolitok koropa. Rybohoshodarska nauka Ukrainy, 2, 73-81.

19. Palamarchuk, R. A., \& Deren, O. V. (2018). Vyznachennia efektyvnosti vykorystannia amarantu (Amaranthus) v hodivli koropa za riznykh umov vyroshchuvannia. Rybohoshodarska nauka Ukrainy, 2, 103-115.

20. Palamarchuk, R. A., \& Deren, O. V. (2018). Vplyv amarantu Amaranthus (Linnaeus) na yakisni ta produktyvni kharakterystyky dvolitok koropa (Cyprinus 
carpio (Linnaeus)) za vvedennia yoho do skladu ratsionu. Rybohospodarska nauka Ukrainy, 3, 89-102.

21. Alekin, O. A. (1970). Osnovy gidrokhimii. Leningrad: Gidrometeoizdat.

22. Voda rybohospodarskykh pidpryiemstv. Zahalni vymogy ta normy. (2006). SOU05.01.-37-385:2006. Kyiv: Ministerstvo ahrarnoi polityky Ukrainy.

23. Krazhan, S. A., \& Khyzhniak, M. I. (2014). Pryrodna kormova baza rybohospodarkykh vodoim. Kyiv: Ahrarna osvita.

24. Arsan, O. M., Davydov, O. Ya., Diachenko, T. M., Yevtushenko, M. Yu. \& Zhukynskyi, V. M. (2006) Metody hidroekolohichnykh doslidzhen poverkhnevykh vod. V. D. Romanenko (Ed.). Kyiv : Lohos.

25. Opredelitel presnovodnykh bespozvonochnykh Evropeyskoy chasti SSSR (plankton $i$ bentos) (1977). L. A. Kutikova \& Ya. I. Starobogatov (Ed.). Leningrad : Gidrometeoizdat.

26. Zheltov, Yu. O. (2003). Metodychni vkazivky z provedennia doslidiv po hodivli ryb. Rybne hospodarstvo, 62, 23-28.

27. Limanskiy, A. A., Yarzhombek, A. A., Bekina, E. N., \& Andronikov, S. B. (1984). Instruktsiya po fiziologo-biokhimicheskim analizam ryb. Moskva: VNIIPRKh.

28. Kiselev, I. V. (1980). Biologicheskie osnovy osemeneniya i inkubatsii kleykikh yaits karpovykh ryb. Kyiv: Naukova dumka.

29. Tomylenko, V. H., Oleksiienko, O. O., \& Kucherenko A. P. (1995). Instruktsiia z orhanizatsii pleminnoi roboty $\mathrm{v}$ koropivnytstvi Ukrainy. Intensyvne rybnytstvo. Kyiv: Ahrarna nauka, 3-33.

30. Plokhinskiy, N. A. (1981). Biometriya. Moskva: Moskovskiy universitet. 


\title{
ПЕРСПЕКТИВИ ВИКОРИСТАННЯ БІЛКОВИХ КОМПОНЕНТІВ НЕТРАДИЦІЙНОГО ПОХОДЖЕННЯ В КОМБІКОРМАХ ДЛЯ АКВАКУЛЬТУРИ (ОГЛЯД)
}

\author{
B. В. Бех, vitbekh@online.ua, Національний університет біоресурсів і \\ природокористування України, м. Київ
}

В. П. Марценюк, vadymarts@online.ua, Національний університет біоресурсів і природокористування України, м. Київ

Н. Й. Тушницька, n-tushnitska@ukr.net, Інститут рибного господарства НАAН України, м. Київ

Мета. Проаналізувати наукові інформаційні джерела щодо досвіду та перспектив використання білкових компонентів нетрадиційного походження в комбікормах для аквакультури.

Результати. Доведено, що останніми роками налагоджене масштабне виробництво ASI (Algae, Single cell proteins/oils and Insects - далі ASI) протеїну має економічну конкурентоспроможність, а кінцевий продукт $\epsilon$ рівноцінним до рибного борошна за профілем незамінних амінокислот та загальною поживною иінністю. Як $і$ одноклітинні організми, комахи також є перспективним джерелом корму, оскільки вони містять не лише цінні компоненти, але й мають додаткові речовини, що несуть користь для здоров'я тварин порівняно зі звичайними кормами. Незважаючи на те, що виробництво білка з комах знаходиться в початковій стадії, пілотні дослідження показали вагомі позитивні результати.

Виробництво ASI-продуктів має значно менший негативний вплив на навколишнє природне середовище як стосовно викидів парникових газів, так і витрат води та енергії. Продукування мікробіологічного протеїну має незначне техногенне навантаження; зростають обмеження у виробництві рослинних білків, включаючи обмежену площу ріллі, постачання води та добрив, та пов'язані з цим супутні екологічні проблеми.

В Європі ідея розвитку промислового виробництва ASI-продуктів набирає обертів у значному маситабі.

Регламент EC (2015/2283), пов'язаний із використанням комах, а також білків одноклітинних у кормах для тварин, значно розширив перелік можливого їх використання. Таким чином, очевидно, що комахи та водорості незабаром будуть становити глобальну реалістичну потенційну альтернативу чи доповнення для кормів у аквакультурі.

Наукова новизна. Розвиток нових альтернативних сталих кормових ресурсів $є$ одним із ключових довгострокових рішень десіциту високопоживного корму для аквакультури. В даний час більшість доступних альтернативних кормових ресурсів, які використовуються, мають наземне походження, включаючи рослинні білки та олії - основні компоненти комбікормів. Таким чином, аквакультура зараз конкурує за використання агропродукції $з$ тваринництвом, енергетикою та прямим споживанням людиною, що викликає певну стурбованість впливом комбікормової промисловості на глобальну продовольчу безпеку.

Практична значимість. Обмеження щодо доступності компонентів тваринного походження та їх висока собівартість призводять до широкого використання наземних рослинних продуктів як головного джерела білка та енергії, що є певною альтернативою

() В. В. Бех, В. П. Марценюк, Н. Й. Тушницька, 2020 
морським інгредієнтам. В ідеалі, повинно відбутись забезпечення комбікормової промисловості кормовими ресурсами в достатній кількості та якості, за відсутності прямої харчової конкуренції з людиною. Таким чином перед виробниками комбікормів та кінцевими споживачами рибопродукції постало питання: чи дійсно побічні продукти тваринного чи рослинного походження є безпечними при використанні їх у якості комбікорму для аквакультури та чи справді вони здатні конкурувати з рибним борошном та риб'ячим жиром природного походження.

Ключові слова: компоненти комбікормів, нутрощі, пір'яне та кров'яне борошно, комахи, одноклітинні організми, білок.

\title{
OUTLOOK OF USING PROTEIN COMPONENTS OF NON-TRADITIONAL ORIGIN IN AQUACULTURE FEEDS (REVIEW)
}

\author{
V. Bekh, vitbekh@online.ua, National University of Life and Environmental Sciences of \\ Ukraine, Kyiv \\ V. Martseniuk, vadymarts@online.ua, National University of Life and Environmental \\ Sciences of Ukraine, Kyiv

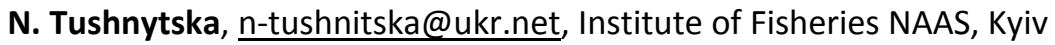

Purpose. To analyze scientific information sources on the experience and outlook of using protein components of non-traditional origin in compound feeds for aquaculture.

Findings. It has been proven that large-scale production of ASIs (Algae, Single cell proteins/oils and Insects - hereinafter ASI) has been achieved during recent years and their economic competitiveness has been demonstrated, while the quality of the end product is comparable to that of fishmeal in terms of essential amino acids and overall nutritional value. Like single-celled organisms, insects are also promising feed ingredients, as they contain not only valuable nutrients but also additional nutrients that are beneficial to animal health compared to conventional feed sources. Despite the fact that the production of insect protein is in its initial stage, pilot studies have shown significant positive results.

The production of ASI-products has a much smaller environmental impact in terms of both greenhouse gas emissions and water and energy consumption. Microbial protein production has a low anthropogenic load, while restrictions on plant protein production are increasing, including limited land, water and fertilizer supplies, and related environmental issues.

In Europe, the idea of developing industrial production of ASIs is gaining ground.

The new European Regulation EU (2015/2283) related to the use of insects and unicellular proteins in animal feed has significantly expanded the list of possible uses. Thus, it is obvious that insects and algae will soon be a global realistic potential alternative or supplement for aquaculture feeds.

Originality. The development of new alternative sustainable feed resources is one of the key long-term solutions to aquaculture food shortages. Currently, most of the alternative feed resources that are used are of terrestrial origin, including vegetable proteins and oils, the main ingredients for aquaculture. Aquaculture is now competing for the use of livestock, energy, and direct human consumption, raising concerns about the impact of the feed industry on global food security.

Practical value. Restrictions on the availability of high-cost animal ingredients and their high cost lead to the widespread use of terrestrial plant products as a major source of protein and energy, which is a definite alternative to marine ingredients. Ideally, providing the feed industry with feed resources of sufficient quantity and quality that will not directly compete with the human food chain. Thus, feed producers and end-users of fish products have been asked whether animal or vegetable byproducts are safe when used as feed for aquaculture and whether they are truly capable of competing with fishmeal and fish oil of natural origin.

Keywords: feed ingredients, gut, feather and blood meal, insects, single cell organisms, protein. 


\title{
ПЕРСПЕКТИВЫ ИСПОЛЬЗОВАНИЯ БЕЛКОВЫХ КОМПОНЕНТОВ НЕТРАДИЦИОННОГО ПРОИСХОЖДЕНИЯ В КОМБИКОРМАХ ДЛЯ АКВАКУЛЬТУРЫ (ОБЗОР)
}

\author{
B. В. Бех, vitbekh@online.ua, Национальный университет биоресурсов и \\ природопользования Украины, г. Киев
}

В. П. Марценюк, vadymarts@online.ua, Национальный университет биоресурсов и природопользования Украины, г. Киев

Н. И. Тушницкая, n-tushnitska@ukr.net, Институт рыбного хозяйства НАAН, г. Киев

Цель. Проанализировать научные информационные источники об опыте и перспективах использования белковых компонентов нетрадиционного происхождения в комбикормах для аквакультуры.

Результаты. Доказано, что достигнутое в последние годы маситабное производство ASI (Algae, Single cell proteins / oils and Insects - далее ASI) протеина имеет экономическую конкурентоспособность, а конечный продукт сопоставим по качеству с рыбной мукой по профилю незаменимых аминокислот и общей питательной ценности. Как и одноклеточные организмы, насекомые также являются перспективными кормовыми ингредиентами, поскольку они содержат не только ценные питательные вещества, но и имеют дополнительные компоненты, несущие пользу для здоровья животных по сравнению с обычными источниками кормов. Несмотря на то, что производство белка из насекомых находится в начальной стадии, пилотные исследования показали веские положительные результаты.

Производство ASI-продуктов несет значительно меньшее негативное влияние на окружающую среду как по выбросу парниковых газов, так и расходу воды и энергии. Выработка микробиологического белка оказывает незначительную техногенную нагрузку; возрастают ограничения в производстве растительных белков, включая ограниченную площадь земли, снабжение водой и удобрениями, и связанные с этим экологические проблемы.

В Европе идея развития промышленного производства ASI - продуктов набирает обороты в значительном маситабе.

Новый европейский Регламент ЕС (2015/2283), связанный с использованием насекомых, а также белков одноклеточных в кормах для животных значительно расширил перечень возможного их использования. Таким образом, очевидно, что насекомые и водоросли вскоре будут составлять глобальную реалистичную потенциальную альтернативу или дополнение для кормов в аквакультуре.

Научная новизна. Развитие новых альтернативных постоянных кормовых ресурсов является одним из ключевых долгосрочных решений дефицита корма для аквакультуры. В настоящее время большинство используемых доступных альтернативных кормовых ресурсов имеют наземное происхождение, включая растительные белки и масла основные ингредиенты для аквакормов. Таким образом, аквакультура сейчас конкурирует за использование урожая с животноводством, энергетикой и прямым потреблением человеком, вызывая определенную обеспокоенность влиянием на комбикормовую промышленность и глобальную продовольственную безопасность.

Практическая значимость. Ограничения по доступности ингредиентов животного происхождения и их высокая себестоимость приводят к широкому использованию наземных растительных продуктов как главного источника белка и энергии, являющих определенной альтернативой морским ингредиентам. В идеале, необходимо обеспечить комбикормовую промышленность кормовыми ресурсами в достаточном количестве и качестве, при отсутствии прямой пищевой конкуренции с человеком. Таким образом, производители комбикормов и конечные потребители рыбопродукции предстали перед вопросом: действительно ли побочные продукты животного или растительного происхождения являются безопасными при использовании их в качестве комбикорма для аквакультуры и 
действительно ли они способны конкурировать с рыбной мукой и рыбьим жиром природного происхождения.

Ключевые слова: компоненты комбикормов, внутренности, перьевая и кровяная мука, насекомые, одноклеточные организмы, белок.

\section{ПОСТАНОВКА ПРОБЛЕМИ ТА АНАЛІЗ ОСТАННІХ ДОСЛІДЖЕНЬ І ПУБЛІКАЦІЙ}

Очікується, що населення Планети до 2050 р. перевищить 9 мільярдів і, відповідно продовольчий розрив у забезпеченні продуктами харчування та їх потребою збільшиться через обмеження кліматичними та природними ресурсами, доступністю ріллі та прісних вод, водночас із підвищенням конкуренції 3 рекреацією та виробництвом продуктів для домашніх тварин.

Аквакультура - найбільш швидко зростаючий сектор тваринництва i, мабуть, один 3 найбільш важливих секторів глобальної продовольчої системи. При цьому тваринництво постійно шукає нові джерела білка для вирішення поточних завдань, оскільки 3 розвитком економік країн, а також 3 ростом населення планети зростає глобальна потреба в продуктах харчування [23].

Різноманітні зв'язки між різними секторами глобальної економіки $\epsilon$ достатньо складними; особливо це стосується виробництва кормів для тваринництва та аквакультури, оскільки продукція цих галузей значною мірою залежить від наявності компонентів зернових та олійних культур, а також малоцінної промислової риби у якості сировини. Тому будь-які коливання та нестабільність цін через низькі врожаї, або обмеження промислу призводить до відповідного збільшення вартості вирощуваної риби або м'ясних продуктів [19].

Витрати на кормові ресурси, такі як рибне борошно, є дуже високими і їх доступність у майбутньому буде значно обмежено. В даний час близько $70 \%$ білка для кормів для тварин імпортується в Європу, в майбутньому безпека європейської економіки та стабільність ланцюгів постачання знаходиться під значним ризиком посилення глобальної конкуренції за продовольчі продукти, корми та паливо за обмежених природних ресурсів.

Тому в багатьох країнах здійснюється пошук нових альтернативних інгредієнтів для кормів на основі доступних місцевих ресурсів, з метою зниження витрат, покращення їх якості та максимально ефективного використання земельних, водних та енергетичних ресурсів.

Сталий розвиток рибальства у природних водоймах Світового океану в останні роки є значно обмеженим та ускладненим. Відповідно, саме тому аквакультура, що забезпечує щорічний глобальний приріст $\sim 7 \%$, і є важливою рушійною силою у виробництві нового джерела тваринного білка для харчування людини та, в майбутньому, можливо, окремих домашніх тварин [23].

Розвиток аквакультури залежить від стійкого постачання кормового білка, поживних речовин та енергетичних ресурсів. На сьогоднішній день сектор виробництва комбікормів для аквакультури є основним споживачем морських ресурсів, таких як рибне борошно та риб'ячий жир, проте через швидке зростання цього сектора та неможливість стабільного постачання, пропозиція вищезазначеної сировини не задовольняє зростаючий попит. Саме тому, 
майбутній розвиток нових альтернативних сталих кормових ресурсів $є$ одним із ключових довгострокових вирішень дефіциту якісного корму для аквакультури. В даний час більшість доступних альтернативних кормових ресурсів, які використовуються, мають наземне походження, включаючи рослинні білки та олії - основні компоненти комбікормів для аквакультури. Таким чином, сектор аквакультури зараз конкурує за використання агропродукції 3 іншими напрямками: тваринництвом, енергетикою та прямим споживанням людиною, що викликає певну стурбованість впливом комбікормової промисловості на глобальну продовольчу безпеку [19].

Інші альтернативні інгредієнти кормів - це побічні продукти тваринного походження, що містять високий вміст білка, ліпідів і широко застосовуються за межами Свропи. Однак ці інгредієнти виробляються з відходів переробки тварини (наприклад, субпродукти з великої рогатої худоби), що значно обмежені як в Європейському Союзі (СС № 956/2008), так і в Сполучених Штатах (США FDA CPG, розділ 675.400). Хоча існує законодавство (Регламент СС 999/2001, 1069/2009 та 142/2011) щодо заборони використання окремих харчових відходів у кормовій промисловості (як, наприклад, борошно з жуйних тварин), змінами 2013 р. до європейського законодавства (Регламент ЄС 56/2013) дозволено застосовувати пташині продукти, такі як нутрощі, пір'яне та кров'яне борошно у кормовиробництві. Незважаючи на ці зміни, паралельне поєднання соціальних факторів та ринкових механізмів щодо постійних обмежень, гальмують широке використання побічних продуктів тваринного походження в межах Європи. Водночас, обмеження щодо доступності інгредієнтів тваринного походження та їх висока собівартість призводять до широкого використання рослинних продуктів як головного джерела білка та енергії, що $є$ певною альтернативою морським інгредієнтам. Проте, 3 погляду конкуренції за землекористування, сільськогосподарські культури, що вирощені для споживання безпосередньо людиною, у поєднанні зі зростаючим світовим попитом на них є недостатньо надійними та економічно доцільними у довгостроковій перспективі. В ідеалі, потрібно забезпечити комбікормову промисловість кормовими ресурсами в достатній кількості та якості за відсутності прямої конкуренції з харчовими потребами людини. Таким чином перед виробниками комбікормів та кінцевими споживачами рибопродукції постало питання: чи дійсно побічні продукти тваринного чи рослинного походження є безпечними при використанні їх у якості комбікорму для аквакультури, та чи справді вони здатні конкурувати з рибним борошном та риб'ячим жиром природного походження [22]?

\section{МАТЕРІАЛИ ТА МЕТОДИ}

Проаналізовано результати сучасних вітчизняних і зарубіжних наукових досліджень щодо можливостей використання нетрадиційних біологічних організмів в якості джерела унікальних за якістю біологічно активних компонентів та поживних речовин для годівлі риб.

Методи досліджень - аналітичні, теоретичного узагальнення.

\section{РЕЗУЛЬТАТИ ДОСЛІДЖЕНЬ ТА ЇХ ОБГОВОРЕННЯ}

Аквакультура країн ЄС посідає п’яте місце за величиною у світі 3 виробництвом 1,3 млн, т. Однак, при цьому, Свросоюз є найбільшим світовим 
імпортером продуктів рибного господарства та аквакультури, причому 57\% продуктів аквакультури споживається в СС 3 країн, що не входять до СС [23]. Таким чином, в Європі існує необхідність збалансування рибогосподарського комплексу з погляду імпорту та експорту морепродуктів 3 метою подальшого стійкого зростання сектора європейської аквакультури. Цей головний виклик можна вирішити, максимізуючи інноваційні, інтеграційні, екологічно чи економічно вигідні виробничі технології.

Останніми роками у СС, США та інших промислово розвинутих країнах відбувається достатньо швидкий розвиток виробництва у промислових обсягах водоростей, білкових та олійних продуктів з одноклітинних організмів та комах (ASI-продуктів); що може мати значний вплив на доступність зазначених інгредієнтів для продукування кормів для різних видів риб та ракоподібних.

В Україні також $є$ спроби використати нетрадиційні джерела протеїну у якості корму для аквакультури. Наприклад, показники якості рибного борошна i соєвого концентрату у порівнянні між собою мають незначну розбіжність, проте при цьому соєвий концентрат на порядок дешевше.

Напрямки застосування і норми введення соєвого білкового концентрату для аквакультури, в залежності від виду риб, складають — від 50 до 100\% заміни рибного борошна [1].

Соєві протеїнові концентрати — це продукти глибокої переробки сої. У порівнянні з соєвим шротом, харчова цінність соєвих концентратів набагато вища, а рівень олігосахаридів і антигенних чинників $є$ дуже низьким.

Кормові дріжджі являють собою суху концентровану біомасу інактивовних дріжджових клітин, що спеціально вирощуються 3 метою наступного згодовування в складі кормів. Особливо перспективним $є$ використання препаратів кормових дріжджів у стартових кормах для осетрових риб, що визначаються можливістю повної відмови від застосування кормових організмів зоопланктону для годівлі молоді на ранніх етапах онтогенезу [3].

Дослідженнями інших авторів встановлено [2], що у продукції з комах міститься $30-70 \%$ якісного протеїну. Вміст протеїну та жиру в личинках комах у порівнянні 3 рибо-кістовим або знежиреним соєвим борошном наведено у таблиці 1.

Таблиия 1. Вміст протеїну та жиру в личинках комах і компонентах тваринницьких кормів [2]

Table 1. Protein and fat content of insect larvae and livestock feed components

\begin{tabular}{|c|c|c|}
\hline $\begin{array}{l}\text { Джерело протеїну / } \\
\text { Source of protein }\end{array}$ & $\begin{array}{l}\text { Сирий протеїн, \% } \\
\text { / Crude protein }\end{array}$ & $\begin{array}{l}\text { Сирий жир, \% } \\
\text { / Raw fat }\end{array}$ \\
\hline Муха чорний солдат (Hermetia illucens) / Black soldier fly & $35-57$ & 35 \\
\hline Звичайна домашня муха (Musca domestica) / The house fly & $43-68$ & $4-32$ \\
\hline $\begin{array}{l}\text { Жовтий борошняний хрущак (Tenedrio molitor) / The } \\
\text { mealworm }\end{array}$ & $44-69$ & $23-47$ \\
\hline \multicolumn{3}{|l|}{ Борошно / Meal } \\
\hline рибо-кістове / fish-bone & $61-77$ & $11-17$ \\
\hline соєве знежирене / soybean non-fat & $49-56$ & 3 \\
\hline м'ясо-кісткове / meat-bone & $30-50$ & $13-20$ \\
\hline
\end{tabular}


За вмістом сирого протеїну сировина з личинок вказаних комах незначно поступається рибо-кістковому борошну, проте значно перевищує значення для знежиреного соєвого та м'ясо-кісткового борошна. Протеїни, отримані з комах, $\epsilon$ легкозасвоюваними, із значеннями якості, подібними або навіть кращими, ніж 3 м'ясо-кісткового або соєвого борошна, завдяки збалансованому складу незамінних амінокислот: аргініну, лізину і метіоніну. Експерименти з додаванням до раціону корму личинок домашніх мух (Musca domestica), личинок мухи чорний солдат (Hermetia illucens), домашніх цвіркунів (Gryllus assimilis), жовтого борошняного хрущака (Tenebrio Molitor) і різних видів лускокрилих свідчать про підвищення середньодобових приростів деяких видів риб у аквакультурі [2].

Поживна цінність черв'яків (E. fetida) зумовлена присутністю в них як високоякісних білків, так і мінеральних компонентів, що визначає можливість їхнього використання в якості вітамінно-білкової кормової добавки для тварин. Доведено, що додавання до раціону риби черв'яків разом 3 вермикомпостом у дозі, що не перевищує 10\% від маси комерційного корму, дозволяє замінювати рибне борошно. Дощові черв'яки (E. fetida) містять мікроелементи $\mathrm{Fe}, \mathrm{Cu}, \mathrm{Mn}, \mathrm{Zn}$ тощо, а також вітаміни комплексів А і В, ферменти і т.п. [4].

Проте важливо пам'ятати, що жодне з цих джерел білка, олії чи жиру не $\epsilon$ взаємозамінним, тому їх слід вважати взаємодоповнюваними при майбутньому виробництві кормів.

Водорості, одноклітинні організми (дріжджі та бактерії), як джерело білка, жирних кислот, вітамінів та біоактивних речовин $є$ одними 3 найбільш перспективних кормових інгредієнтів для аквакультури в майбутньому, в т.ч. 3 метою покращення якісних та поживних характеристик кінцевої продукції [7, 14, 22]. Крім того, окремі мікроорганізми та рослини є джерелами унікальних білків та вітамінів, а також здатні формувати ланцюгові Омега-3 ліпіди.

Водночас, комахи здатні переробляти субстрати з низьким вмістом поживних речовин на білок та жири - компоненти складових кормів 3 підвищеною поживною цінністю. Було підраховано, що вирощені в ставах мікроводорості можуть виробляти більше 50 т білка/га на рік, що в 10-15 разів перевищує стандартне виробництво сої та в 25-50 разів — виробництво кукурудзи [16].

Кутура з співавторами [6] запропонував механізм виробництва кормових ресурсів 3 мікроорганізмів, таких як бактеріальне борошно та продукти 3 дріжджів з низьким вмістом вуглецю.

Окрім того, що в останні роки досягнуто масштабне виробництво ASIпротеїну та забезпечено його економічну конкурентоспроможність, кінцевий продукт $є$ порівняним за якістю 3 рибним борошном за профілем незамінних амінокислот та загальною поживною цінністю $[11,12,15]$. Як і одноклітинні організми, комахи також є перспективними кормовими інгредієнтами, оскільки вони містять не тільки цінні поживні речовини, але й мають додаткові речовини, що несуть користь для здоров'я тварин порівняно зі звичайними джерелами кормів $[9,10]$. Незважаючи на те, що виробництво білка з комах знаходиться на початковому етапі, пілотні дослідження показали вагомі позитивні результати. Зокрема, дослідження з годівлі підтвердили, що харчові профілі, смакові якості та засвоюваність рибних кормів, що містять продукти з комах, можна порівняти 3 кормами на основі традиційного рибного та соєвого борошна $[10,20]$. 
Виробництво ASI-продуктів справляє значно менший негативний вплив на навколишнє природне середовище як стосовно викидів парникових газів, так i витрат води та енергії. Продукування мікробіологічного протеїну має незначне техногенне навантаження, в той час як зростають обмеження у виробництві рослинних білків, включаючи обмежену площу землі, постачання води та добрив та пов'язані екологічні проблеми [15]. Прийнято вважати, що мікроводорості, бактерії, дріжджі та певні види комах можуть сприяти глобальній харчовій безпеці при виробництві кормів і що їх вдосконаленню потрібно приділяти значну увагу.

В Європі ідея розвитку промислового виробництва ASI-продуктів набирає обертів у значному масштабі $[7,8]$.

Регламент СС (2015/2283), пов'язаний із використанням комах, а також одноклітинних білків у кормах для тварин, значно розширив перелік можливого їх використання. Таким чином, очевидно, що комахи та водорості незабаром будуть становити глобальну реалістичну потенційну альтернативу чи доповнення для кормів у аквакультурі.

Дослідження показують, що організми ASI можуть швидко розвиватись на ряді органічних та неорганічних субстратів, забезпечуючи економічну доцільність та сприяючи зменшенню обсягу різноманітних відходів. В якості субстратів можна використовувати недорогі відходи харчової промисловості, зокрема, при виробництві пива чи інших напоїв.

Культивування організмів ASI також можливо проводити безпосередньо за використання відходів лісового та сільського господарства.

Крім того, в експериментальному пілотному проекті було показано, що існує можливість культивування одноклітинних мікроорганізмів (бактерій та водоростей) при використанні неорганічного вуглецю $\mathrm{CO}_{2}$ та метану. Цей напрям дозволяє також значно мінімізувати викиди парникових газів у атмосферу.

Дослідження останніх років також засвідчили безпеку та якість продуктів 3 комах, які є потенційними об'єктами для розвитку масштабного, економічно вигідного виробництва. Відповідно, $є$ сподівання, що ASI-продукти будуть достатньо охоче схвалені на ринку як проміжними (кормовиробники), так i кінцевими споживачами продукції аквакультури.

Окремі недавні дослідження повідомили про можливість та економічну доцільність сталого виробництва мікроводоростей при використанні скидних вод інтегрованого рибного господарства в рамках комплексного підходу мультитрофічної аквакультури, де мікроводорості виконували функції біоочищення та годівлі молоді риб [13]. Інші останні наукові дослідження показали ефективність використання окремих видів мікроводоростей, вирощених за допомогою класичних хімічних добрив, в складі раціонів для годівлі риби [5].

Очевидно, що комерційне виробництво водоростей та бактерій вже досягає певного промислового масштабу, тоді як розвиток виробництва комах поки що знаходиться на початковому рівні. Хоча продукти 3 водоростей мають установлені ринки збуту як для харчових продуктів, так і для кормів, вони традиційно зосереджені лише на частковому застосуванні водоростей при виробництві кормів. В першу чергу, їх використовують як джерело спеціалізованих харчових добавок, наприклад, для отримання Омега-3 жирних 
кислот, каротиноїдів та вітамінів, проте, як повноцінне джерело протеїну вони $є$ відносно недооцінені.

У секторі аквакультури білкові продукти, олії та жири, що виробляються мікроорганізмами, використовуються на личинкових стадіях розвитку морських риб та ракоподібних, а останнім часом також при їх підрощуванні. Також 3'явились дослідження та технології використання ASI-продуктів 3 метою підвищення вмісту Омега-3 жирних кислот в рибному філе, що збільшує цінність харчової продукції $[18,22]$.

На сьогоднішній день висока собівартість виробництва одноклітинної біомаси у великомасштабних гетеротрофних ферментаторах або автотрофних водоймах (ставах) / реакторах обмежує їх використання в якості складової в кормах для аквакультури. Однак використання органічних та неорганічних субстратів, відходів харчової промисловості чи сільського господарства як потенційного джерела для виробництва одноклітинної біомаси в даний час досліджуються достатньо активно, завдяки зростаючій зацікавленості у широкомасштабному виробництві мікроводоростей для біопалива, біологічної сировини та цінних біоактивних сполук [17]. Таким чином, для того щоб бути економічно вигідним у короткостроковій перспективі, а також для того щоб ASI-продукти оперативно та широко були впроваджені у кормовій галузі, виробничі витрати повинні бути суттєво знижені.

Однак існує кілька ключових проблем, котрі потребують вирішення як для водоростей-бактерій, так і комах, щоб стати важливою частиною промислових комбікормів для аквакультури. В даний час біопродукти 3 комах i біомаса водоростей все ще виробляються у відносно невеликому / середньому масштабі, що призводить до надмірно високої собівартості порівняно 3 більшістю рослинних білкових джерел.

\section{ВИСНОВКИ ТА ПЕРСПЕКТИВИ ПОДАЛЬШОГО РОЗВИТКУ}

Відповідно до інформації Міжнародної платформи продуктів харчування та кормів 3 комах (IPIFF), приватні та урядові інвестиції в зазначений сектор можуть сягнути 2 млрд євро до 2025 р., що значною мірою допоможе прискорити розгортання об'єктів комерційного масштабу цього нового напрямку. Прогнозується, що, зі збільшенням обсягів, виробництво швидко стане більш економічно доцільним та конкурентноспроможним [21]. В коротко- та середньостроковій перспективі, важливо, щоб компанії - світові лідери 3 виробництва комбікормів для аквакультури підтримали тестування та верифікацію ASI-продуктів, що необхідно для виявлення їх потенційних можливостей, користі для здоров'я гідробіонтів та визначення економічної складової їх культивування.

\section{ЛІТЕРАТУРА}

1. Макаринська А. В., Оганесян А. А. Переваги використання білкових рослинних концентратів при виробництві комбікормової продукції // Зернові продукти і комбікорми. 2018. Т. 18, № 3. С. 34-39.

2. Метлицька О. І., Мельничук С. Д., Спиридонов В. Г. Комахи - джерело поживних і біологічно активних речовин // Вісник аграрної науки. 2017. № 6. C. $29-35$. 
3. Симон М. Ю. Використання кормових дріжджів у годівлі осетрових (Acipenserinae) видів риб (огляд) // Рибогосподарська наука України. 2015. № 4. С. $100-126$.

4. Титов И. Н., Усоев В. М. Вермикультура как возобновляемый источник животного белка из органических отходов // Вестник Томского государственного университета. 2012. № 2 (18). С. 74-80. (Биология).

5. Microalgae as a potential ingredient for partial fish meal replacement in aquafeeds: nutrient stability under different storage conditions / Camacho-Rodriguez J. et al. // J. Applied Phycol. 2018. DOI: 10.1007/s10811-017-1281-5.

6. Environmental benefits of novel non-human food inputs to salmon feeds / Couture J. L. et al. // Environmental Science and Technology. 2019. DOI: 10.1021/acs.est.8b03832.

7. Gamboa-Delgado J., Márquez-Reyes J. M. Potential of microbial-derived nutrients for aquaculture development // Reviews in Aquaculture. 2016. Vol. 10, iss. 1. P. $224-246$.

8. Gorry P.-L., Sánchez L., Morales M. Microalgae Biorefineries for Energy and Coproduct Production // Energy from Microalgae. Green Energy and Technology. Cham : Springer, 2018. DOI: 10.1007/978-3-319-69093-3_5.

9. Review on the use of insects in the diet of farmed fish: past and future. / Henry M. et al. // Animal Feed Science and Technology, 2015. Vol. 203. P. 1-22.

10. State-of-the-art on use of insects as animal feed / Makkar H. P. S. et al. // Animal Feed Science and Technology. 2014. Vol. 197. P. 1-33.

11. Can direct conversion of used nitrogen to new feed and protein help feed the world? / Matassa S. et al. // Environ. Sci. Technol. 2015. Vol. 49, iss. 9. P. 52475254.

12. Microbial protein: future sustainable food supply route with low environmental footprint / Matassa S. et al. // Microbial biotechnology. 2016. Vol. 9(5). P. 568575.

13. Milhazes-Cunha H., Otero A. Valorisation of aquaculture effluents with microalgae: The integrated multi-trophic aquaculture concept // Algal Res. 2017. Vol. 24. P. 416-424.

14. Pathways of lipid metabolism in marine algae, co-expression network, bottlenecks and candidate genes for enhanced production of EPA and DHA in species of Chromista / Mühlroth A. et al. // Mar Drugs. 2013. Vol. 22. P. 4662- 4697.

15. Evaluation of methane-utilising bacteria products as feed ingredients for monogastric animals / Øverland M. et al. // Archives of animal nutrition. 2010. Vol. 64(3). P. 171-189.

16. Pelczar J., Chan E. C. S. Microbiology - An Application Based Approach. New Delhi, India : Tata McGraw Hill, 2010. 919 p.

17. Perez-Garcia O., Bashan Y. Algal biorefineries. Vol. 2: Products and refinery design. Switzerland : Springer International Publishing, 2015. P. 61-132.

18. Microbial protein produced from brown seaweed and spruce wood as a feed ingredient / Sharma S. et al. // Journal of agricultural and food chemistry. 2018. Vol. 66(31). P. 8328-8335.

19. Does aquaculture add resilience to the global food system? / Troell M. et al. // Proc Natl Acad Sci USA. 2014. Vol.111. P. 13257-13263.

20. Van Huis A., Oonincx D. G. A. B. The environmental sustainability of insects as food and feed. A review // Agronomy for Sustainable Development. 2017. Vol. 37. P. 43. 
21. Edible Insects: Future Prospects for Food and Feed Security / Van Huis et al. Rome, Italy : FAO, 2013. (FAO Forestry Paper ; 171). URL : http://www.fao.org/docrep/018/i3253e/i3253e.pdf (accessed : 7.10.2017).

22. Macroalgae as a sustainable aquafeed ingredient / Wan A. H. L. et al. // Reviews in Aquaculture. 2019. Vol. 11, iss. 3. P. 458 - 492. DOI: 10.1111/raq.12241.

\section{REFERENCES}

1. Makarynska, A. V., \& Ohanesian, A. A. (2018). Perevahy vykorystannia bilkovykh roslynnykh kontsentrativ pry vyrobnytstvi kombikormovoi produktsii. Zernovi produkty i kombikormy, 18(3), 34-39.

2. Metlytska, O. I., Melnychuk, S. D., \& Spyrydonov, V. H. (). Komakhy - dzherelo pozhyvnykh i biolohichno aktyvnykh rechovyn. Visnyk ahrarnoi nauky, 6, 29-35.

3. Symon, M. Yu. (2015). Vykorystannia kormovykh drizhdzhiv u hodivli osetrovykh (Acipenserinae) vydiv ryb (ohliad). Rybohospodarska nauka Ukrainy, 4, 100-126.

4. Tytov, Y. N., \& Usoev, V. M. (2012). Vermykultura kak vozobnovliaemyi ystochnyk zhyvotnoho belka iz orhanycheskykh otkhodov. Vestnyk Tomskoho hosudarstvennoho unyversyteta. Byolohyia, 2 (18), 74-80.

5. Camacho-Rodriguez, J., et al. (2018). Microalgae as a potential ingredient for partial fish meal replacement in aquafeeds: nutrient stability under different storage conditions. J. Applied Phycol. DOI: 10.1007/s10811-017-1281-5.

6. Couture, J. L., Geyer, R., Øverland, M., Sahlmann, C., Hansen, J. Ø., Palazzo, J., \& Lenihan, H. (2019). Environmental benefits of novel non-human food inputs to salmon feeds. Environmental Science and Technology. Doi: 10.1021/acs.est.8b03832.

7. Gamboa-Delgado, J., \& Márquez-Reyes, J. M. (2016). Potential of microbial-derived nutrients for aquaculture development. Reviews in Aquaculture, 10(1), 224-246.

8. Gorry, P.-L., Sánchez, L., \& Morales, M. (2018). Microalgae Biorefineries for Energy and Coproduct Production. Energy from Microalgae. Green Energy and Technology. Cham: Springer. DOI: 10.1007/978-3-319-69093-3_5.

9. Henry, M., Gasco, L., Piccolo, G., \& Fountoulaki, E. (2015). Review on the use of insects in the diet of farmed fish: past and future. Animal Feed Science and Technology, 203, 1-22.

10. Makkar, H. P. S., Tran, G., Heuzé, G., \& Ankers, P. (2014). State-of-the-art on use of insects as animal feed. Animal Feed Science and Technology, 197, 1-33.

11. Matassa, S., Batstone, D. J., Hülsen, T., Schnoor, J., \& Verstraete, W. (2015). Can direct conversion of used nitrogen to new feed and protein help feed the world? Environ. Sci. Technol., 49(9), 5247-5254.

12. Matassa, S., Boon, N., Pikaar, I., \& Verstraete, W. (2016). Microbial protein: future sustainable food supply route with low environmental footprint. Microbial biotechnology, 9(5), 568-575.

13. Milhazes-Cunha, H., \& Otero A. (2017). Valorisation of aquaculture effluents with microalgae: The integrated multi-trophic aquaculture concept. Algal Res., 24, 416424.

14. Mühlroth, A., et al. (2013). Pathways of lipid metabolism in marine algae, coexpression network, bottlenecks and candidate genes for enhanced production of EPA and DHA in species of Chromista. Mar Drugs, 22, 4662-4697. 
15. Øverland, M., Tauson, A. H., Shearer, K., \& Skrede, A. (2010). Evaluation of methane-utilising bacteria products as feed ingredients for monogastric animals. Archives of animal nutrition, 64(3), 171-189.

16. Pelczar, J., \& Chan, E. C. S. (2010). Microbiology - An Application Based Approach. New Delhi, India: Tata McGraw Hill.

17. Perez-Garcia, O., \& Bashan, Y. (2015). Algal biorefineries. (Vol. 2. Products and refinery design). Switzerland: Springer International Publishing, 61-132.

18. Sharma, S., Hansen, L. D., Hansen, J. Ø., Mydland, L. T., Horn, S. J., Øverland, M., \& Vuoristo, K. S. (2018). Microbial protein produced from brown seaweed and spruce wood as a feed ingredient. Journal of agricultural and food chemistry, 66(31), 8328-8335.

19. Troell, M., et al. (2014). Does aquaculture add resilience to the global food system? Proc Natl Acad Sci USA, 111, 13257-13263.

20. Van Huis, A., \& Oonincx, D. G. A. B. (2017). The environmental sustainability of insects as food and feed. A review. Agronomy for Sustainable Development, 37, 43.

21. Van Huis, A., et al. (2013). Edible Insects: Future Prospects for Food and Feed Security. FAO Forestry Paper. (Vol. 171). Rome, Italy: FAO, 2013. Retrieved from http://www.fao.org/docrep/018/i3253e/i3253e.pdf.

22. Wan, A. H. L., et al. (2019). Macroalgae as a sustainable aquafeed ingredient. Reviews in Aquaculture, 11(3), 458-492. DOI: 10.1111/raq.12241. 


\section{ІХТІОПАТОЛОГІЯ}

\section{НІДОВІРУСНІ ІНФЕКЦІї РИБ ТА КРЕВЕТОК (ОГЛЯД)}

Л. П. Бучацький, iridolpb@gmail.com, Інститут рибного господарства НАAН України, м. Київ

Ю. П. Рудь, rudziknew@ukr.net, Інститут рибного господарства НААН України, М. Київ

О. В. Залоїло, ozaloilo@yahoo.com, Інститут рибного господарства НАAН України, м. Київ

I. A. Залоїло, zaloilo@yahoo.com, Національний університет біоресурсів та природокористування України, м. Київ

I. І. Грициняк, hrytsyniak@ukr.net, Інститут рибного господарства НАAН України, м. Київ

Мета. Проаналізувати масив спеціальної літератури та узагальнити отриману інформацію щодо нідовірусних інфекцій риб та креветок. Розглянути структурнофункціональні особливості представників порядку Nidovirales, а також симптоми та наслідки викликаних ними захворювань.

Результати. Представлена робота містить короткий аналітично узагальнений огляд вірусів з порядку Nidovirales, представники якого є збудниками захворювань риб та креветок. Наведено актуальну класифікацію нідовірусів. Розглянуто морфологічні та генетичноструктурні особливості цих вірусів, описано відомі механізми їх реплікації та інші функціональні властивості. Особливу увагу приділено опису симптомів та особливостей розвитку нідовірусних інфекцій гідробіонтів.

Практична значимість. Огляд може бути корисним для науковців, які досліджують представників порядку Nidovirales та проблеми, пов'язані з хворобами, спричинені даними вірусами. Описи симптомів захворювань будуть корисними для попередньої діагностики нідовірусних інфекцій у риб та креветок.

Ключові слова: нідовіруси риб, нідовіруси креветок, бафінівірус, окавірус, нідовірусна інфекція, геном нідовірусів.

\section{NIDOVIRAL INFECTIONS OF FISH AND PRAWN: A REVIEW}

L. Buchatsky, iridolpb@gmail.com, Institute of Fisheries of NAAS of Ukraine, Kyiv Yu. Rud, rudziknew@ukr.net, Institute of Fisheries of NAAS of Ukraine, Kyiv O. Zaloilo, ozaloilo@yahoo.com, Institute of Fisheries of NAAS of Ukraine, Kyiv I. Zaloilo, zaloilo@yahoo.com, National University of Life and Environmental Sciences, Kyiv

I. Hrytsyniak, hrytsyniak@ukr.net, Institute of Fisheries of NAAS of Ukraine, Kyiv

(ㄱ Л. П. Бучацький, Ю. П. Рудь, О. В. Залоїло, І. А. Залоїло, І. І. Грициняк, 2020 
Purpose. Nidoviruses are wide spread pathogens of animals and humans. The order Nidovirales covers enveloped viruses with one segment of linear positive-sense single-stranded RNA. The order comprises four families including Coronaviridae, Arteriviridae, Roniviridae and Mesoniviridae. Despite numerous studies, Nidoviruses remain poorly understood today. The complexity of replication mechanisms and significant differences in genome size of individual families are the main problem to understand the life cycle of these viruses. Therefore, we tried to analyze the array of special literature data and summarize the information obtained on nidoviral infections of fish and prawns, structural and functional properties of the Nidovirales members, and the symptoms and consequences of diseases caused by them.

Findings. The presented data contain a brief analytical summary of viruses from the Nidovirales order, which infect fish and prawns. The current classification of water nidoviruses is noted. The morphological and genetic structure of fish nidoviruses as well as the known mechanisms of their replication and other functional properties are shown. Particular attention is paid to the description of symptoms and routes of nidovirus infection development in aquatic organisms. However, effective prevention and treatment of nidoviral infections is unknown. Currently, significant number of nidoviruses is insufficiently studied: partially or completely remain uncharacterized mechanisms of replication, genomic structure, the interactions with environment condition and virus spread, etc.

Practical Value. The review may be useful for scientists studying representatives of Nidovirales order and problems associated with diseases caused by these viruses. The description of disease symptoms will help in preliminary diagnosis of nidoviral infections in fish and prawns and raise awareness concerning its possible negative impact on aquaculture. Further development of knowledge about the morphological and molecular biological properties of nidoviruses, as well as the study of disease symptoms in aquatic organisms is promising direction for both purely biological aspects and for sustainable aquaculture.

Keywords: fish nidoviruses, shrimp nidoviruses, bafinivirus, okavirus, nidoviral infection, nidovirus genome.

\section{НИДОВИРУСНЫЕ ИНФЕКЦИИ РЫБ И КРЕВЕТОК (ОБЗОР)}

Л. П. Бучацкий, iridolpb@gmail.com, Институт рыбного хозяйства НАAН, г. Киев

ю. П. Рудь, rudziknew@ukr.net, Институт рыбного хозяйства НАAН, г. Киев

О. В. Залоило, ozaloilo@yahoo.com, Институт рыбного хозяйства НАAН, г. Киев

И. А. Залоило, zaloilo@yahoo.com, Национальный университет биоресурсов и природопользования Украины, г. Киев

И. И. Грициняк, hrytsyniak@ukr.net, Институт рыбного хозяйства НАAH, г. Киев

Цель. Проанализировать массив специальной литературы и обобщить полученную информацию о нидовирусних инфекциях рыб и креветок. Рассмотреть структурнофункциональные особенности представителей порядка Nidovirales, a также симптомы и последствия вызванных ими заболеваний.

Результаты. Представленная работа содержит краткий аналитически обобщенный обзор вирусов порядка Nidovirales, представители которых являются возбудителями заболеваний рыб и креветок. Приведена актуальная классификация нидовирусов. Рассмотрены морфологические и генетико-структурные особенности этих вирусных организмов, описаны известные механизмы их репликации и прочие функциональные свойства. Особое внимание уделено описанию симптомов и особенностей развития нидовирусных инфекций гидробионтов.

Практическая значимость. Обзор может быть полезным для ученых, исследующих представителей порядка Nidovirales и проблемы, связанные с болезнями, вызванными

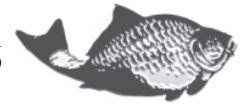


данными вирусами. Описания симптомов заболеваний будут полезными для предварительной диагностики нидовирусных инфекций у рыб и креветок.

Ключевые слова: нидовирусы рыб, нидовирусы креветок, бафинивирус, окавирус, нидовирусная инфекция, геном нидовирусов.

\section{ПОСТАНОВКА ПРОБЛЕМИ. МЕТА РОБОТИ}

Нідовіруси - поширені збудники захворювань тварин і людини. До порядку Nidovirales входять вкриті оболонкою віруси 3 односегментною лінійною одноланцюговою РНК позитивної полярності [1]. Всіх нідовірусів об'єднує наявність у вірусному геномі фіксованого місця генерації мРНК, якому дали назву «Nido», що в перекладі з латинської мови означає «гніздо» $[2]$.

Незважаючи на численні наукові дослідження, порядок Nidovirales залишається недостатньо вивченим і сьогодні. Основною проблемою розуміння життєдіяльності нідовірусів є складність механізмів реплікації та суттєві відмінності у розмірах геномів представників окремих родин.

Дана робота $є$ аналітичним узагальненням результатів сучасних досліджень нідовірусів гідробіонтів (креветок та риб). Зважаючи на те, що більшість емерджентних вірусів мають зоогенне походження, представлений огляд може бути корисним для розуміння структурних та функціональних особливостей нідовірусних збудників захворювань людини, у тому числі - й коронавірусу COVID-19 [3], який, поряд 3 іншими представниками родини Coronaviridae, входить до порядку Nidovirales.

\section{АНАЛІЗ ТА ОБГОВОРЕННЯ СУЧАСНИХ ДОСЛІДЖЕНЬ І ПУБЛІКАЦІЙ}

Згідно з сучасною класифікацією (ICTV), до порядку Nidovirales входять 9 родин. Нідовіруси риб входять до складу родини Tobaniviridae, нідовіруси креветок входять до складу родин Roniviridae та Euroniviridae (табл. 1).

До складу родини Tobaniviridae входять два роди: Bafinivirus та Oncotshavirus. Назва роду Bafinivirus походить від перших двох літер англійських слів «bacilla», «fish» та «nidovirus»: вірус має форму бацили (рис. 1).

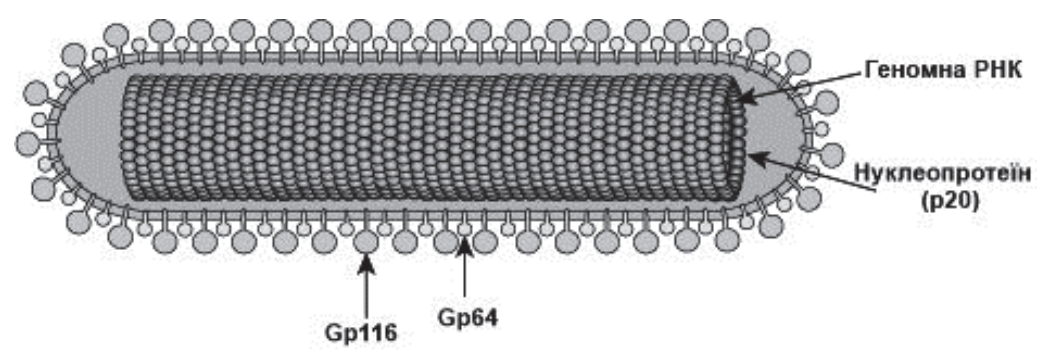

Рис. 1. Схема будови віріону бафінівірусів риб (https://viralzone.expasy.org/resources/Roniviridae_virion.jpg)

Fig. 1. Schematic structure of fish bafinivirus 


\section{Табличя 1. Нідовіруси риб та креветок}

Table 1. Nidoviruses of fish and prawn

\begin{tabular}{|c|c|c|c|}
\hline Родина & Рід & Вид & Хазяїн \\
\hline \multirow[t]{5}{*}{ Tobaniviridae } & Bafinivirus & 1.White bream virus (WBV) & Плоскирка \\
\hline & & 2. Fathead minnow nidovirus (FHMV) & $\begin{array}{c}\text { Товстоголосий } \\
\text { гольян }\end{array}$ \\
\hline & Oncotshavirus & 1. Chinook salmon nidovirus (CSBV) & \\
\hline & & 2. Crucian carp nidovirus (CCNV) & Чавича \\
\hline & & & Карась \\
\hline \multirow[t]{2}{*}{ Roniviridae } & Okavirus & 1. Gill-associated virus (GAV) & Креветка \\
\hline & & 2. Yellow head virus (YHV) & Креветка \\
\hline Euroniviridae & Charybnivirus & Decronivirus (DecNV) & Креветка \\
\hline
\end{tabular}

Бафінівірус плоскирки. Плоскирка (Blicca bjoerkna L.) розповсюджена у Свропі в басейнах Північного, Балтійського, Чорного, Азовського та Каспійського морів. В Україні зустрічається на всій території. Бафінівірус плоскирки вперше було виділено у Німеччині при дослідженні популяцій риб, виловлених у природних водоймах [4]. В англомовній літературі йому дали назву WBV. Вiрус не викликає видимих патологічних змін в уражених особин, його дія проявляється лише у перещеплюваних культурах клітин риб.

Bipioни WBV мають типову для представників роду Bafinivirus форму бацили довжиною 130-160 нм і діаметром 37-45 нм. Віріон має ліпідну оболонку 3 розташованими на ній відростками (пепломерами) висотою 25 нм. Поліаденильована одноланцюгова PHK WBV містить п’ять генів, які кодують відкриті рамки зчитування (ORF1a, 1b, 2, 3 i 4). Ген ORF1a/1b кодує поліпротеїни ppla i pplab, які містять в собі протеїназу, полімеразу та інші ферментиреплікази, загальні для всіх нідовірусів; ORF2, ORF3 i ORF4 кодують глікопротеїн відростків $(\mathrm{S})$, мембранний $(\mathrm{M})$ і нуклеокапсидний $(\mathrm{N})$ білки $[5,6]$.

Бафінівірус товстоголового гольяна. Бафінівірус товстоголового гольяна (Pimephales promelas) було виявлено у США у 1997 році [7]. Вірус у англомовних публікаціях отримав назву FHMNV (fathead minnow virus). Він розмножується в перещеплюваних клітинах ЕPC, FHM і RTG у діапазоні температур від 15 до $25^{\circ} \mathrm{C}$. У клітинах, інфікованих FHMNV, відбувається утворення синцитіїв (рис. 2).

Захворювання у товстоголового гольяна характеризується змінами у поведінці: риби спочатку хаотично плавають по колу, а потім стають млявими і опускаються на дно басейна або нерухомо зависають біля поверхні води зі спрямованою догори головою. Перебіг хвороби залежить від температурного режиму. У воді за температури $19^{\circ} \mathrm{C}$ смерть риб настає вже через 3 дні після зараження, а при $17^{\circ} \mathrm{C}$ уражені особини починають гинути лише через 13 днів після інфікування. Хвороба товстоголового гольяна супроводжується крововиливами на шкірі, у печінці, нирках та селезінці. 


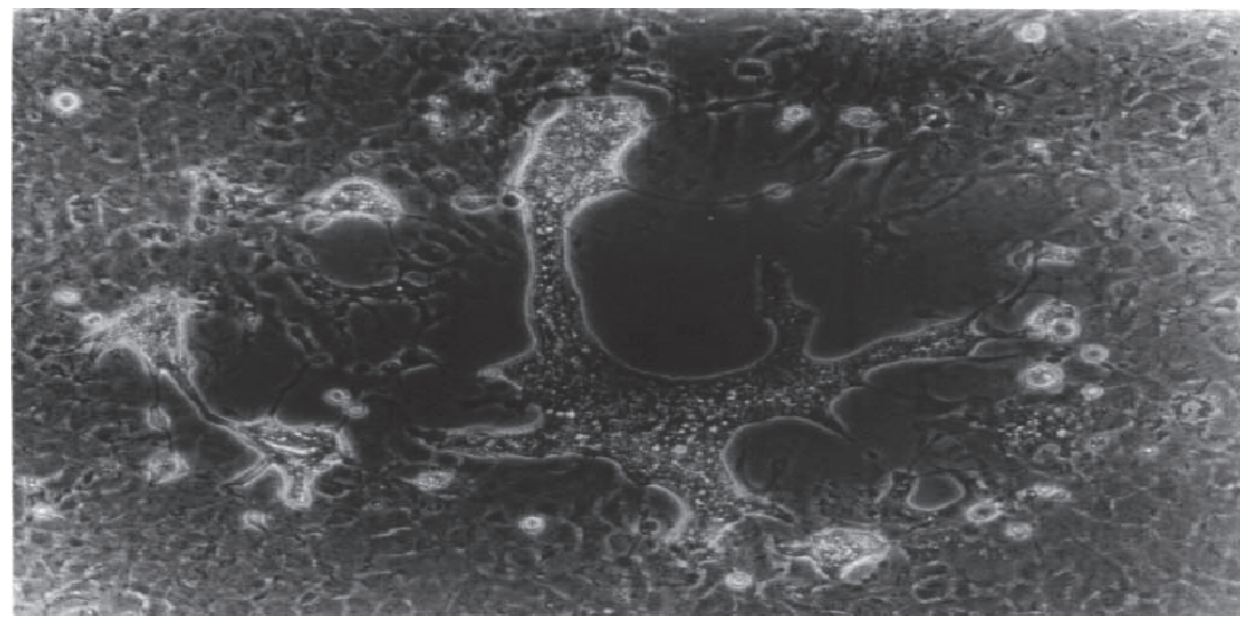

Рис. 2. Утворення синцитіїв у клітинах ЕРС, інфікованих бафінівірусом товстоголового гольяна [7].

Fig. 2. Formation of syncytia in EPC cells, infected by bafinivirus (FHMV) of fathead minnow (Pimephales promelas) [7].

Інколи проявами цього захворювання можуть бути і крововиливи в м'язи. Внаслідок потемніння і набряків нирки, м'язи риб стають видимими зовні, що може бути корисним для первинної діагностики [8]. FHMNV має високу видову специфічність: показано, що канальний сом (Ictalurus punctatus), карась (Carassius) і синець звичайний (Ballerus ballerus) до нього є нечутливими [7].

Bipioни FHMNV мають форму паличок довжиною 130-185 нм і діаметром 31-47 нм. Наразі встановлено повну послідовність генома даного віруса [9]. Одноланцюгова РНК віруса містить 27000 нуклеотидів і схожа з бафінівірусом плоскирки. Результати порівняння генних продуктів гелікази (домен pplab), S, M, $\mathrm{N}$ i ORF 1ab 3 продуктами гена WBV свідчить про гомологічну відмінність: ступінь варіабельності знаходиться у діапазоні від 15 (білок S) до 70\% (геліказа) [9-11].

Бафінівірус карася. Бафінівірус карася, або золотої рибки, (Carassius auratus) вперше було описано у 2019 р. [12] і названо C CNV (crucian carp nidovirus). Геном віруса містить 25971 нуклеотидів і має 5 відкритих рамок зчитування, які кодують поліпротеїни $1 \mathrm{ab}(\mathrm{pp} 1 \mathrm{ab})$, глікопротеїн пепломерів (S), білок мембран (M) і білок нуклеокапсида $(\mathrm{N})$. За будовою генома даний вірус $\epsilon$ близьким до бафінівірусу чавичі. Вищезгадані автори пропонують обидва цих віруси об’єднати в новий рід Oncotshavirus.

Нідовірус чавичі. Вперше нідовірус чавичі (Oncorhynchus tshawytscha) було виявлено канадськими вченими у 2014 р. [13]. Вірус отримав назву CSBV. Biн реплікується та індукує цитопатичні ефекти в клітинах RTG-2 i EPC за температури 15,20 і $25^{\circ} \mathrm{C}$.

Вірусні частинки мають паличкоподібну форму діаметром 45 нм і довжиною 120-130 нм. Геном віруса містить 27004 нуклеотиди, організація його генів нагадує структуру інших коронавірусів. Повна послідовність нуклеотидів даного вірусу розміщена в банку геномів NCBI (№ KJ 681496). За амінокислотним 
складом цей вірус є близькоспорідненим з WBV i FHMV.

Інший нідовірус лососевих також було виявлено канадськими науковцями у атлантичного лосося (Salmo salar). Збуднику дали назву ASBV (Atlantic salmon bafinivirus). Вірус розмножується в перещеплюваних клітинах, отриманих 3 різних видів риб. Широкий спектр чутливості культур клітин до цього віруса може свідчити про широке коло його господарів у природному середовищі.

При вивченні повної послідовності нуклеотидів геному ASBV було встановлено, що він на 99\% є подібним до нідовірусу чавичі (CSBV), відрізняючись, однак, наявністю значної делеції у гені поліпротеїну реплікази pp1a. Аналіз послідовності генома виявив передбачуваний шостий білок, який може бути представлений поліпептидом 360 амінокислот; ймовірно це - білок оболонки $[14,15]$.

Бафінівірус білого амура. Бафінівірус білого амура (Ctenopharyngodon idella) було виділено німецькими іхтіопатологами у 1987 р. [16]. Проте, геном цього вірусу ще не секвенований, і тому його не внесено до офіційного списку ICTV. Бафінівірус було виявлено у процесі транскордонного ветеринарного контролю у зовні здорових особин риб, надісланих з Угорщини. Виділений вірус добре розмножувався у перещеплюваних клітинах, отриманих з плавців золотої рибки (Carassius auratus), у лейкоцитах коропа (Cyprinus carpio) та клітинах FHМ в межах температурного діапазону $20-25^{\circ} \mathrm{C}$. Інфіковані клітини 3 часом злипалися, після чого спостерігався їх лізис. Методом електронно-мікроскопічних досліджень уражених клітин було встановлено, що вірусні частинки мають форму бацили довжиною 170-220 нм й діаметром 50-55 нм. За допомогою фарбування інфікованих клітин розчином акридин-оранжевого було показано наявність вірусної одноланцюгової РНК. Вірус інактивується хлороформом у кислих середовищах (pH 3,0), а також шляхом підвищення температури середовища до $56^{\circ} \mathrm{C}[17]$.

Бафінівірус коропа. Через рік після виділення бафінівірусу білого амура його аналог було виявлено у Японії під час спалаху гострої інфекції у коропа звичайного (Cyprinus carpio). В уражених бафінівірусом особин спостерігалася еритема у черевній ділянці та некрози у печінці й нирках. Трансмісія віруса до молодих коропів здійснювалася через водне середовище за температури $20^{\circ} \mathrm{C}$ [18]. У цій же країні було описано і бафінівірус сазана (C. carpio) при вивченні захворювання під назвою «ана-аки-біо» [19]. При цьому захворюванні патологічні зміни у риб спостерігалися у вісцеральних органах, вірусні частинки виявляли у гематопоетичних тканинах та селезінці [17]. В інфікованих клітинах ЕРС вірус викликає каріопікноз і призводить до формування в них внутрішньоклітинних вакуоль. Як і бафінівірус білого амура, бафінівірус коропа ще не внесений до офіційного списку ICTV.

Окавіруси креветок. Окавіруси креветок входять до родини Ronivirus. Назва родини містить поєднання слів «Rod» («паличка») та таксономічну назву порядку (Nidovirales). Назва роду Okavirus походить від назви лімфоїдного органу креветок («ока»), у якому накопичуються віруси креветок [20].

Окавірус креветок (yellow head virus - YHV) викликає захворювання у тигрової креветки Penaeus monodon під назвою «жовта голова». Цим вірусом можуть бути інфіковані й інші види креветок та криль. Вперше хвороба тигрової 
креветки була описана у Тайланді [21]. У даний час окавірус виявлено в Південно-Східній Азії, Австралії, Америці та Східній Африці [22, 23].

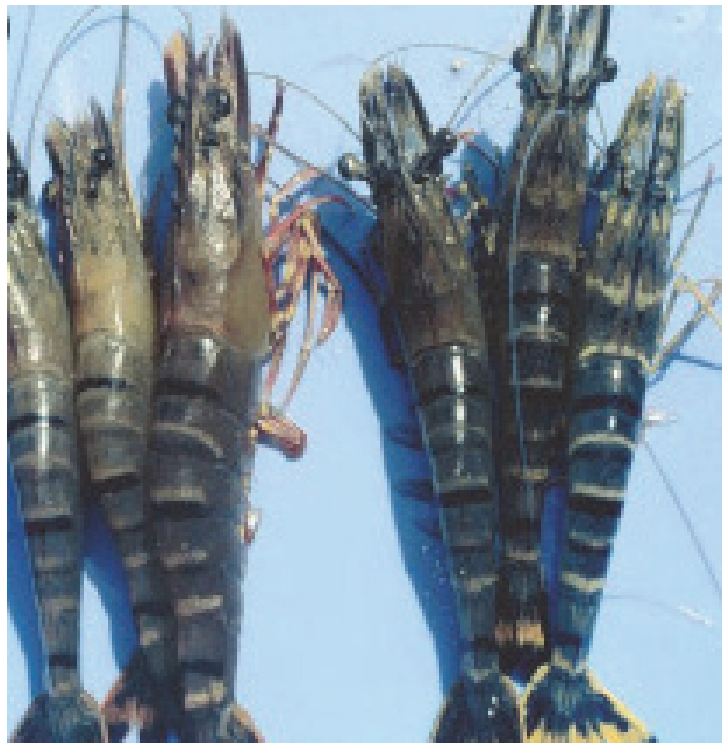

Рuc. 3. Гігантські тигрові креветки, вражені YHV (ліворуч). Праворуч здорові креветки. [24]).

Fig. 3. The giant tiger prawn, infected by YHV (left) and healthy (right) [24]).

Існує шість генотипів окавірусу креветок. Генотип $1-$ це YHV, другий генотип - вірус, асоційований з зябрами креветок (GAV). Генотипи 3-6 окавірусу креветок $є$ слабопатогенними i не викликають ніяких ознак захворювання [25]. До роду Okavirus відносять також нідонавірус, який був виділений з блакитного краба Callinectes sapidus [26].

Найбільш чутливими до окавірусу є личинки креветок масою 5-15 г. Втім, дорослі особини також можуть інфікуватись даним збудником: зараження окавірусами відбувається при поїданні креветками загиблих особин або може здійснюватися безпосередньо через воду, шляхом контакту з сітками для вилову, інструментами тощо [27-29].

У інфікованих креветок перебіг захворювання може бути як гострим, так i хронічним, а трансмісія здійснюється як горизонтально, так і вертикально. Під час гострої інфекції смертність креветок буває значною і вірус виявляється у більшості тканин ектодермального та мезодермального походження; найбільше його міститься у лімфоїдному органі «Ока». У некротичних клітинах креветок виявляють базофільні цитоплазматичні включення. YHD призводить до 90-100\% загибелі креветок протягом трьох-п'яти днів після прояву перших симптомів захворювання. На початкових стадіях інфікування у креветок протягом декількох днів відзначається надзвичайно високий апетит, після чого вони раптово перестають живитися [24, 30]. У інфікованих особин спостерігається набряк травних залоз. Приблизно через добу хворі креветки починають хаотично плавати поблизу поверхні води. У них часто можна спостерігати бліді або блідо-жовті зябра та блідо-жовтий гепатопанкреас (орган, що поєднує функцію печінки i 
підшлункової залози). Ще через одну добу головогруди інфікованих тварин набувають інтенсивного жовтого кольору. Потім кількість уражених інфекцією креветок різко зростає і на третю добу після появи описаних симптомів гине все поголів'я. Після закінчення епізоотії вірус за температури $25-28^{\circ} \mathrm{C}$ може залишатися життєздатним у воді ще впродовж 4 діб.

Віріони окавірусу креветок - паличкоподібної форми (40-60 нм×150-200 нм) з заокругленими кінцями. Вони мають зовнішню оболонку, вкриту шипами (пепломерами), які виступають приблизно на 11 нм від поверхні віріона. Нуклеокапсидам діаметром 20-30 нм притаманна спіральна симетрія 3 періодичністю 5-7 нм. Довгі ниткоподібні попередники нуклеокапсидів (приблизно 15 нм діаметром і 80-450 нм завдовжки) трапляються у цитоплазмі інфікованих клітин і набувають форми оболонки вірусу шляхом брунькування на мембранах ендоплазматичного ретикулума. Новостворені зрілі віріони 3 оболонкою часто формують скупчення, у результаті чого можуть виникати паракристалічні упаковки. Віріони містять одноланцюгову молекулу РНК позитивної полярності, довжина якої варіює від 26235 нуклеотидів для вірусу GAV і до 26662 нуклеотидів для представників YHV.

У геномі GAV після перших 68 нуклеотидів, які містять 5'-кінцевий 7метилгуанозиновий кеп, розташовано 5 довгих відкритих рамок зчитування (5'ORF1a-ORF1b-ORF2-ORF3-ORF4-3') і на 3'-кінці $є$ ділянка poly А. Рамки ORF1a/ORF1b кодують великий ген реплікази, рамка ORF2 - ген нуклеопротеїну, рамка ORF3 - ген глікопротеїну. Білок з цього гену зчитується у вигляді поліпротеїну, який надалі шляхом протеолізу розщеплюється на глікопротеїни gp116 та gp64. Те, що ген глікопротеїну розміщується після гену нуклеопротеїну, є унікальною особливістю серед інших вірусів порядку Nidovirales. Функції ORF4 невідомі, білок, який вона кодує у GAV, містить 83 амінокислоти і $є$ недостатньо вивченим. Між рамками ORF1a та ORF1b iснує «сліпа» послідовність AAAUUUU, за допомогою якої відбувається зсув рамки на один нуклеотид. Така структурна особливість дозволяє зчитувати ORF1b, що містить консервативні послідовності, які кодують ген гелікази, а також домени для зв'язування іонів металів та домен полімерази.

Поряд 3 описаними вище, сьогодні детально вивчені геноми й інших нідовірусів водних тварин, у тому числі - коронавіруса морського котика [31, 32], коронавіруса білухи [33], коронавіруса дельфіна-афаліни [34], нідовірусів планарій та молюсків [35, 36].

\section{ВИСНОВКИ ТА ПЕРСПЕКТИВИ ПОДАЛЬШОГО РОЗВИТКУ}

Таким чином, викладений вище аналіз літератури свідчить про широке розповсюдження нідовірусів риб та креветок у різних регіонах світу. Як і іншим вірусам $з$ одноланцюговою РНК позитивної полярності, нідовірусам риб та креветок притаманна порівняно висока здатність до рекомбінацій та мутацій [37]. Це дозволяє їм швидко адаптуватись до нових хазяїв і до нових екологічних ніш, тобто набувати статусу емерджентності. Відомо, що більшість емерджентних нідовірусів мають зоогенне походження [38]. Наприклад, описані випадки виділення вірусів, подібних до коронавірусу атипової пневмонії людей (нідовірус), у гімалайських пальмових цивет та усурійського єнота [39]. Філогенетичний аналіз геномів різних нідовірусів свідчить про те, що багато 3 
них, у тому числі і збудники людських хвороб, можуть бути нащадками нідовірусів водних організмів [40].

Нідовіруси $є$ поширеними збудниками інфекційних захворювань, що завдають значних збитків об'єктам аквакультури. Однак ефективне запобігання та лікування нідовірусних інфекцій неможливе без детального дослідження механізмів життєдіяльності збудників. Наразі значна кількість представників порядку Nidovirales є недостатньо вивченою: частково чи цілком залишаються невідомими механізм реплікації, геномна структура, залежність поширення нідовірусів від зовнішніх факторів тощо. Подальше розширення уявлень про описані вище морфологічні та молекулярно-біологічні особливості нідовірусів, а також дослідження симптомів викликаних ними захворювань у гідробіонтів, $\epsilon$ перспективним напрямком як у суто біологічному аспекті, так i для більш продуктивного ведення сучасної аквакультури.

\section{ЛІТЕРАТУРА}

1. Макаров В. В. Избранные вопросы общей эпизоотологии и инфектологии-ІІІ. Москва : РУДН, 2010. 182 с.

2. Lai M., Cavanagh D. The molecular biology of coronaviruses // Adv. Virus Res. 1997. Vol. 48. P. 1-100.

3. Isolation and characterization of viruses related to the SARS coronavirus from animals in southern China / Guan Y. et al. // Science. 2003. Vol. 302. P. 276-278.

4. Identification and ultrastructural characterization of a novel virus from fish / Granzow H. et al. // J Gen Virol. 2001. Vol. 82. P. 2849-2859.

5. Batts W. N., Goodwin A. E., Winton J. R. Genetic analysis of a novel nidovirus from fathead minnows // J Gen Virol. 2012. Vol. 93. P. 1247-1252.

6. Ulferts R., Mettenleiter T. C., Ziebuhr J. Characterization of Bafinivirus main protease autoprocessing activities // J Virol. 2011. Vol. 85(3). P. 1348-1359.

7. Iwanowicz L. R., Goodwin A. E. A new bacilliform fathead minnow rhabdovirus that produces syncytia in tissue culture // Arch Virol. 2002. Vol. 147. P. 899-915.

8. Retail Baitfish in Michigan Harbor Serious Fish Viral Pathogens / Boonthai T. et al. // J Aquat Anim Health. 2018. Vol. 30(4). P. 253-263.

9. Characterization of White bream virus reveals a novel genetic cluster of nidoviruses / Schütze H. et al. // J Virol. 2006. Vol. 80. P. 11598-11609.

10. Isolation of the Fathead Minnow Nidovirus from Muskellunge Experiencing Lingering Mortality / Faisal M. et al. // J Aquat. Anim. Health. 2016. Vol. 28(2). P. $131-141$.

11. Baird A., Faisal M. Fathead minnow nidovirus infects spotfin shiner Cyprinella spiloptera and golden shiner Notemigonus crysoleucas // Dis Aquat Organ. 2016. Vol. 12. № 119(1). P. 37-44.

12. Isolation and genetic analysis of a nidovirus from crucian carp (Carassius auratus) / Chen Xiao-yu et al. // Archives of Virology. 2019. Vol. 164. P.1651-1654.

13. Novel chinook salmon bafinivirus isolation from ontario fish health monitoring / Lord S. D. et al. // The seventh international symposium on aquatic animal health : proceed. Portland, Oregon, United States, 2014. P. 242.

14. Endangered wild salmon infected by newly discovered viruses / Mordecai G. J. et al. // eLife. 2019. Vol. 8. P. 47615.

15. Characterization of a bafinivirus exoribonuclease activity / Durzynska I. et al. // J. Gen Virol. 2018. Vol. 99. P. 1253-1260. 
16. Ahne W., Jiang Y., Thomsen I. A new virus isolated from cultured grass carp Ctenopharyngodon idella // Disease of Aquatic Organisms. 1987. Vol. 3. P. 181185.

17. Antiviral activity of K22 against members of the order Nidovirales / Rappe J. C. F. et al. // Virus Res. 2018. Vol. 246. P. 28-34.

18. Sano T., Yamagaki T., Fukuda H. A novel carp coronavirus: characterization and pathogenicity // International Fish Health Conference : proceed. Vancuver, 1988. P. 160.

19. Viremia-associated ana-aki-byo, a new viral disease in color carp Cyprinus carpio in Japan / Miyazaki T. et al. // Dis Aquat Organ. 2000. Vol. 9. Vol. 39(3). P. 183192.

20. Genetic diversity in the yellow head nidovirus complex / Wijegoonawardanep P. et al. // Virology. 2008 .Vol. 380. P. 213-225.

21. Histology and ultrastructure reveal a new granulosis-like virus in Penaeus monodon affected by yellow-head disease / Chantanachookin C. et al. // Dis. Aquat.Org. 1993. Vol. 17. P. 145-157.

22. Multiple pathogens found, 2004 Multiple Pathogens Found in Growth-Retarded Black Tiger Shrimp Penaeus Monodon Cultivated in Thailand / Chayaburakul K. et al. // Dis Aquat Organ. 2004. Vol. 60(2), Aug 9. P. 89-96.

23. Flegel T. W., Boonyaratpalin S., Withyachumnarnkul B. Current status of research on yellow-head virus and white-spot virus in Thailand // Diseases in Asian Aquaculture III. Manila, The Philippines : Asian Fisheries Society. Fish Health Section, 1997. P. 285-296.

24. Vertical transmission of gill-associated virus (GAV) in the black tiger prawn Penaeus monodon / Cowley J. A. et al. // Dis. Aquat. Org. 2002. Vol. 50. P. 95104.

25. First detection of yellow head virus genotype 3 (YHV-3) in cultured Penaeus monodon, mainland China / Chen J. et al. // J Fish Dis. 2018. Vol. 41(9). P. 14491451.

26. Jahrome S. S. Occurrence of rhabdovirus-like particles in the blue crab Callinectes sapidus // J. Gen. Virol. 1977. Vol. 36. P. 485-493.

27. Yellow-head virus of Penaeus monodon is an RNA virus / Wongteerasupaya C. et al. // Dis. Aquat. Org. 1995. Vol. 22. P. 45-50.

28. Plasmolipin, PmPLP1, from Penaeus monodon is a potential receptor for yellow head virus infection / Matjank W. et al. // Dev Comp Immunol. 2018. Vol. 88. P. $137-143$.

29. Immunostimulation and yellow head virus (YHV) disease resistance induced by a lignin-based pulping by-product in black tiger shrimp (Penaeus monodon Linn.) / Srisapoome P. et al. // Fish Shellfish Immunol. 2018. Vol. 72. P. 494-501.

30. Gill-associated virus of Penaeus monodon prawns: an invertebrate virus with ORF1a and ORF1b genes related to arteri- and coronaviruses / Cowley J. A. et al. // J Gen Virol. 2000. Vol. 81. P. 1473-1484.

31. Bossart G., Schwartz J. Acute necrotizing enteritis associated with suspected coronavirus infection in three harbor seal (Phoca vitulina) // J. Zoo Wildl. Med. 1990. Vol. 21. P. 84-87.

32. Detection of a respiratory coronavirus from tissues archived during a pneumonia epizootic in free-ranging Pacific harbor seals Phoca vitulina richardsii / Nollens H. H. et al. // Dis Aquat Organ. 2010. Vol. 90(2), Jun 11. P. 113-120. 
33. Identification of a Novel Coronavirus from a Beluga Whale by Using a Panviral Microarray / Mihindukulasuriya K. A. et al. // Journal of Virology. 2008. Vol. 82, № 10 . P. $5084-5088$.

34. Discovery of a Novel Bottlenose Dolphin Coronavirus Reveals a Distinct Species of Marine Mammal Coronavirus in Gammacoronavirus / Woo P. et al. // Journal of Virology. 2014. Vol. 88(2). P. 1318-1331.

35. A planarian nidovirus expands the limits of RNA genome size / Saberi A. et al. // Plos Pathog. 2018. Vol. 14(11). e1007314.

36. Description and initial characterization of metatranscriptomic nidovirus-like genomes from the proposed new family Abyssoviridae, and from a sister group to the Coronavirinae, the proposed genus Alphaletovirus / Bukharia A. et al. // Virology. 2018. Vol. 524. P. 160-171.

37. Nidovirales: evolving the largest RNA virus genome / Gorbalenya A. E. et al. // Virus Res. 2006. Vol. 117. P. 17-37.

38. Taylor L. H., Latham S. M., Woolhouse M. E. Risk factors for human disease emergence // Philos Trans R Soc Lond B Biol Sci. 2001. Vol. 356(1411). P. 983989.

39. Макаров В. В., Лозовой Д. А. Коронавирусные зоонозы, ассоциированные с рукокрылыми // Ветеринария сегодня. 2016. Вып. 2. С. 3-8.

40. Emerging novel coronavirus (2019-nCoV)-current scenario, evolutionary perspective based on genome analysis and recent developments / Malik Y. S. et al. // Vet Q. 2020. Vol. 40(1). P. 68-76.

\section{REFERENCES}

1. 1. Makarov, V. V. (2010). Izbrannye voprosy obshchey epizootologii i infektologiiIII. Moskva: RUDN, 182.

2. Lai, M., \& Cavanagh, D. (1997). The molecular biology of coronaviruses. $A d v$. Virus Res., 48, 1-100.

3. Guan, Y., Zheng, B., YQ, H., \& Liu, X., et al. (2003). Isolation and characterization of viruses related to the SARS coronavirus from animals in southern China. Science, 302, 276-278.

4. Granzow, H., Weiland, F., Fichtner, D., Schütze, H., \& Karger, A. (2001). Identification and ultrastructural characterization of a novel virus from fish. J Gen Virol., 82, 2849-2859.

5. Batts, W. N., Goodwin, A. E., \& Winton, J. R. (2012). Genetic analysis of a novel nidovirus from fathead minnows. J Gen Virol., 93, 1247-1252.

6. Ulferts, R., Mettenleiter, T. C., \& Ziebuhr, J. (2011). Characterization of Bafinivirus main protease autoprocessing activities. J Virol, 85(3), 1348-1359.

7. Iwanowicz, L. R., \& Goodwin, A. E. (2002). A new bacilliform fathead minnow rhabdovirus that produces syncytia in tissue culture. Arch Virol., 147, 899-915.

8. Boonthai, T., Loch, T. P., Zhang, Q., Van Deuren, M. G., Faisal, M., Whelan, G. E., \& Herbst, S. J. (2018). Retail Baitfish in Michigan Harbor Serious Fish Viral Pathogens. J Aquat Anim Health, 30(4), 253-263.

9. Schütze, H., Ulferts, R., Schelle, B., Bayer, S., \& Granzow, H. (2006). Characterization of White bream virus reveals a novel genetic cluster of nidoviruses. J Virol, 80, 11598-11609.

10. Faisal M., Baird, A., Winters, A. D., Millard, E. V., Marcquenski, S., Hsu, H. M., \& Hennings, A., et al. (2018). Isolation of the Fathead Minnow Nidovirus from 
Muskellunge Experiencing Lingering Mortality. J Aquat. Anim. Health, 28(2), 131141.

11. Baird, A., \& Faisal, M. (2016). Fathead minnow nidovirus infects spotfin shiner Cyprinella spiloptera and golden shiner Notemigonus crysoleucas. Dis Aquat Organ, 12(119(1)), 37-44.

12. Chen, Xiao-yu, Zhou, Yong, Chen, Xin, Zheng, Jian, Zeng, Xian-dong, \& Ji Feng $\mathrm{Xu}$ Li-ming. (2019). Isolation and genetic analysis of a nidovirus from crucian carp (Carassius auratus). Archives of Virology, 164, 1651-1654.

13. Lord, S. D., Raymond, M. J., Krell, P. J., Kropinski, A. M., \& Stevenson, R. M. (2014). Novel chinook salmon bafinivirus isolation from ontario fish health monitoring. Proceedings of the seventh international symposium on aquatic animal health. Portland, Oregon, United States, 242.

14. Mordecai, G. J., Miller, K. M., Di Cicco, E., \& Schulze, A. D. et al. (2019). Endangered wild salmon infected by newly discovered viruses. eLife, 8, 47615.

15. Durzynska, I., Sauerwald, M., Karl, N., Madhugiri, R., \& Ziebuhr, J. (2018). Characterization of a bafinivirus exoribonuclease activity. J. Gen Virol., 99, 12531260 .

16. Ahne, W., Jiang, Y., \& Thomsen, I. (1987). A new virus isolated from cultured grass carp Ctenopharyngodon idella. Disease of aquatic organisms, 3, 181-185.

17. Rappe, J. C. F., de Wilde, A., Di, H., Müller, C., Stalder, H., V'kovski, P., \& Snijder, E., et al. (2018). Antiviral activity of K22 against members of the order Nidovirales. Virus Res., 246, 28-34.

18. Sano, T., Yamagaki, T., \& Fukuda, H. (1988). A novel carp coronavirus: characterization and pathogenicity. International Fish Health Conference Vancuver, 160.

19. Miyazaki, T., Okamoto, H., Kageyama, T., \& Kobayashi, T. (2000). Viremiaassociated ana-aki-byo, a new viral disease in color carp Cyprinus carpio in Japan. Dis Aquat Organ., 9, 39(3), 183-192.

20. Wijegoonawardanep, P., Cowley, J., \& Phant, T., et al. (2008). Genetic diversity in the yellow head nidovirus complex. Virology, 380, 213-225.

21. Chantanachookin, C., Boonyaratpalin, S., \& Kasornchandra, J., et al. (1993). Histology and ultrastructure reveal a new granulosis-like virus in Penaeus monodon affected by yellow-head disease. Dis. Aquat.Org., 17, 145-157.

22. Chayaburakul K., Nash G., Pratanpipat P., et al. (2004). Multiple pathogens found, Multiple Pathogens Found in Growth-Retarded Black Tiger Shrimp Penaeus Monodon Cultivated in Thailand. Dis Aquat Organ., Aug 9, 60(2), 89-96.

23. Flegel, T. W., Boonyaratpalin, S., \& Withyachumnarnkul, B. (1997). Current status of research on yellow-head virus and white-spot virus in Thailand. Diseases in Asian Aquaculture III. Manila, The Philippines: Asian Fisheries Society, 285-296.

24. Cowley, J. A., Hall, M. R., Cadogan, L. C., Spann, K. M., \& Walker, P. J. (2002). Vertical transmission of gill-associated virus (GAV) in the black tiger prawn Penaeus monodon. Dis. Aquat. Org., 50, 95-104.

25. Chen, J., Wang, W., Wang, X., Zhang, Q., Ren, Y., Song, J., \& Wang, X. (2018). First detection of yellow head virus genotype 3 (YHV-3) in cultured Penaeus monodon, mainland China. J Fish Dis, 41(9), 1449-1451.

26. Jahrome, S. S. (1977). Occurrence of rhabdovirus-like particles in the blue crab Callinectes sapidus. J.Gen.Virol., 36, 485-493.

27. Wongteerasupaya, C., Sriurairatana, S., \& Vickers, J., et al. (1995). Yellow-head virus of Penaeus monodon is an RNA virus. Dis. Aquat. Org., 22, 45-50. 
28. Matjank, W., Ponprateep, S., Rimphanitchayakit, V., Tassanakajon, A., Somboonwiwat, K., \& Vatanavicharn, T. (2018). Plasmolipin, PmPLP1, from Penaeus monodon is a potential receptor for yellow head virus infection. Dev Comp Immunol, 88, 137-143.

29. Srisapoome, P., Hamano, K., Tsutsui, I., \& Iiyama, K. (2018). Immunostimulation and yellow head virus (YHV) disease resistance induced by a lignin-based pulping by-product in black tiger shrimp (Penaeus monodon Linn.). Fish Shellfish Immunol, 72, 494-501.

30. Cowley, J. A., Dimmock, C. M., Spann, K. M., \& Walker, P. J. (2000). Gillassociated virus of Penaeus monodon prawns: an invertebrate virus with ORF1a and ORF1b genes related to arteri- and coronaviruses. J Gen Virol., 81, 1473-1484.

31. Bossart, G., \& Schwartz, J. (1990). Acute necrotizing enteritis associated with suspected coronavirus infection in three harbor seal (Phoca vitulina). J. Zoo Wildl. Med., 21, 84-87.

32. Nollens, H. H., Wellehan, J. F., Archer, L., Lowenstine, L. J., \& Gulland, F. M. (2010). Detection of a respiratory coronavirus from tissues archived during a pneumonia epizootic in free-ranging Pacific harbor seals Phoca vitulina Richardsii. Dis Aquat Organ., Jun 11, 90(2), 113-120.

33. Mihindukulasuriya, K. A., Wu, G., Leger, J. S., Nordhausen, R. W., \& Wang, D. (2008). Identification of a Novel Coronavirus from a Beluga Whale by Using a Panviral Microarray. Journal of Virology, 82(10), 5084-5088.

34. Woo, P., Lau, S., \& Lam, C., et al. (2014). Discovery of a Novel Bottlenose Dolphin Coronavirus Reveals a Distinct Species of Marine Mammal Coronavirus in Gammacoronavirus. Journal of Virology, 88(2), 1318-1331.

35. Saberi, A., Gulyaeva, A., Brubacher, J. L., Newmark, P. A., \& Gorbalenya, A. E. (2018). A planarian nidovirus expands the limits of RNA genome size. Plos Pathog., 14(11), e1007314.

36. Bukharia, A., Mulleya, G., \& Gulyaeva, A., et al. (2018). Description and initial characterization of metatranscriptomic nidovirus-like genomes from the proposed new family Abyssoviridae, and from a sister group to the Coronavirinae, the proposed genus Alphaletovirus. Virology, 524, 160-171.

37. Gorbalenya, A. E., Enjuanes, L., Ziebuhr, J., \& Snijder, E. J. (2006). Nidovirales: evolving the largest RNA virus genome. Virus Res., 117, 17-37.

38. Taylor, L. H., Latham, S. M., \& Woolhouse, M. E. (2001). Risk factors for human disease emergence. Philos Trans R Soc Lond B Biol Sci., 356(1411), 983-989.

39. Makarov, V. V., \& Lozovoy, D. A. (2016). Koronavirusnye zoonozy, assotsiirovannye s rukokrylymi. Veterinariya segodnya, 2, 3-8.

40. Malik, Y. S., Sircar, S., Bhat, S., Sharun, K., Dhama, K., Dadar, M., Tiwari, R., \& Chaicumpa, W. (2020). Emerging novel coronavirus (2019-nCoV)-current scenario, evolutionary perspective based on genome analysis and recent developments. Vet $Q, 40(1), 68-76$. 


\section{EKOHOMIKA}

Ribogospod. nauka Ukr., 2020; 2(52): 78-85

DOI: https://doi.org/10.15407/fsu2020.02.078

УДК 639.3.043:[338.45:639.371.2]
Received 16.02.20

Received in revised form 28.03.20

Accepted 24.04.20

\section{ECONOMIC EFFICIENCY OF GROWING EARLY JUVENILES OF RUSSIAN STURGEON (ACIPENSER GUELDENSTAEDTII BRANDT \& RATZEBURG, 1833) WITH THE INTRODUCTION OF INACTIVATED BAKER'S YEAST IN THEIR DIET}

M. Simon, seemann.sm@gmail.com, Institute of Fisheries NAAS, Kyiv H. Kurinenko, annazakharenko@ukr.net, Institute of Fisheries NAAS, Kyiv N. Kolesnik, kolenataleo@gmail.com, Institute of Fisheries NAAS, Kyiv

Purpose. To determine the main parameters of economic efficiency of the use of inactivated baker's yeast as a biologically active additive in the diet of early juveniles of Russian sturgeon.

Methodology. The calculations were carried out according to generally accepted methods for economic studies. For economic analysis, we used the actual parameters of economic activity in current industrial aquaculture of Ukraine with the use of RAS, as well as prices for 2015-2016 on relevant materials, products and means of production.

Findings. The economic efficiency of introducing 5\% and 15\% (by weight of the main feed) inactivated baker's yeast into the diet of early juvenile Russian sturgeon grown in the RAS has been established. These concentrations allow achieving more than $70 \%$ profitability and reducing the prime cost of one fish to 1.72-1.74 UAH, thereby ensuring high, as compared with other options for feeding, parameters as net (372.96 UAH and 366.86 UAH) and attributable profit (873.0 UAH and 876.0 UAH).

Originality. For the first time, the parameters of economic efficiency of introducing $4(5 \%, 10 \%$, $15 \%, 40 \%$ of the weight of the main feed) concentrations of inactivated baker's yeast into the diet of juvenile Russian sturgeon for 28 days, from 25 to 53 days after hatching were analyzed.

Practical Value. The study results have both theoretical and practical importance and can be used in further studies aimed at optimizing the cultivation of juvenile sturgeons in RAS and adjusting existing feeding schemes on fish farms.

Keywords: economic efficiency, juvenile fish, fish feeding, RAS, Russian sturgeon, baker's yeast.

\section{ЕКОНОМІЧНА ЕФЕКТИВНІСТЬ ВИРОЩУВАННЯ РАННЬОЇ МОЛОДІ POCIЙСЬКОГО OCETPA (ACIPENSER GUELDENSTAEDTII BRANDT \& RATZEBURG, 1833) ЗА ВЕДЕННЯ ДО РАЦІОНУ ІНАКТИВОВАНИХ ПЕКАРСЬКИХ ДРІЖДЖІВ}

М. Ю. Симон, seemann.sm@gmail.com, Інститут рибного господарства НАAН, М. Київ

Г. А. Куріненко, annazakharenko@ukr.net, Інститут рибного господарства НАAН, м. Київ

Н. Л. Колесник, kolenataleo@gmail.com, Інститут рибного господарства НАAН, м. Київ

(C) M. Simon, H. Kurinenko, N. Kolesnik, 2020 
Мета. Визначити основні показники економічної ефективності застосування інактивованих пекарських дріжджів у якості біологічно-активної добавки в раціоні ранньої молоді російського осетра.

Методика. Викладені розрахунки здійснено за загальноприйнятими в економіці методиками. Для економічного аналізу використані фактичні показники господарської діяльності в сучасній індустріальній аквакультурі України, що передбачає використання УзВ, а також ціни 2015-2016 рр. на відповідні матеріали, різноманітні види продукції та засоби виробництва.

Результати. Встановлено економічну доцільність введення 5 та 15\% від маси основного корму інактивованих пекарських дріждів до раціону молоді російського осетра. Дані концентрації дозволяють досягти рівня рентабельності у понад $70 \%$ та знизити собівартість 1 екземпляра до 1,72-1,74 грн, тим самим забезпечуючи найвищі, з-поміж інших варіантів годівлі, показники як чистого (372,96 та 366,86 грн), так і умовного прибутку (873,0 ma 876,0 грн).

Наукова новизна. Вперше проаналізовано показники економічної ефективності введення чотирьох (5, 10, 15, 40\% від маси основного корму) концентрацій інактивованих пекарських дріжджів до раціону молоді російського осетра впродовж 28 діб, з 25 по 53 добу після викльову з ікри.

Практична значимість. Результати досліджень мають як теоретичне, так $i$ практичне значення, та можуть бути використані в подальших дослідженнях щодо оптимізації вирощування молоді осетрових видів риб в УзВ або для корегування вже існуючих схем годівлі на господарствах.

Ключові слова: економічна ефективність, молодь риб, годівля риб, УзВ, російський осетер, пекарські дріжджі.

\section{ЭКОНОМИЧЕСКАЯ ЭФФЕКТИВНОСТЬ ВЫРАЩИВАНИЯ РАННЕЙ МОЛОДИ РУССКОГО ОСЕТРА (ACIPENSER GUELDENSTAEDTII BRANDT \& RATZEBURG, 1833) ПРИ ВВЕДЕНИИ В РАЦИОН ИНАКТИВИРОВАННЫХ ПЕКАРСКИХ ДРОЖЖЕЙ}

М. Ю. Симон, seemann.sm@gmail.com, Институт рыбного хозяйства НАAН, г. Киев А. А. Куриненко, annazakharenko@ukr.net, Институт рыбного хозяйства НАAН, г. Киев

Н. Л. Колесник, kolenataleo@gmail.com, Институт рыбного хозяйства НАAН, г. Киев

Цель. Определить основные показатели экономической эффективности применения в качестве биологически активной добавки инактивированных пекарских дрожжей в рационе ранней молоди русского осетра.

Методика. Изложенные расчеты осуществлены по общепринятым в экономике методикам. Для экономического анализа использованы фактические показатели хозяйственной деятельности в современной индустриальной аквакультуре Украины, предусматривающей использование УзВ, а также цены 2015-2016 г2. на соответствующие материалы, виды продукции и средства производства.

Результаты. Установлена экономическая целесообразность введения 5 и 15\% от массы основного корма, инактивированных пекарских дрожжей в рацион молоди русского осетра, выращиваемой в системе УзВ. Данные концентрации позволяют достичь более чем 70\% уровня рентабельности и снизить себестоимость 1 экземпляра до 1,72-1,74 грн, тем самым обеспечивая высокие, по сравнению с другими вариантами кормления, показатели как чистой (372,96 и 366,86 грн ) так и условной прибыли (873,0 и 876,0 грн).

Научная новизна. Впервые проанализированы показатели экономической эфрективности введения четырех (5, 10, 15, 40\% от массы основного корма) концентраций 
инактивированных пекарских дрожжей в рацион молоди русского осетра в течение 28 суток, с 25 по 53 сутки после выклева из икры.

Практическая значимость. Результаты исследований имеют как теоретическое, так и практическое значение. Они могут быть использованы в дальнейших исследованиях по оптимизации выращивания молоди осетровых видов рыб в УзВ и для корректировки уже существующих схем кормления на хозяйствах.

Ключевые слова: экономическая эфрективность, молодь рыб, кормление рыб, УзВ, русский осетр, пекарские дрожњ.

\section{PROBLEM STATEMENT AND ANALYSIS OF LAST ACHIEVEMENTS AND PUBLICATIONS}

Currently, economic efficiency is perhaps the most important factor determining the feasibility of certain improvements in the production process in fish farming.. First of all, this is due to the fact that in the conditions of a free market economy existing in Ukraine, any establishment should be profitable, providing profit to the owner. At the same time, the latter is almost incapable of influencing the final level of the value of its products, as it is determined by complex market forces. However, the producer of fishery products, in our case - the juvenile Russian sturgeon, is able to influence its cost. The latter directly depends on how intensively the enterprise uses production resources, improves technics and technology, organizes production [1-4].

Therefore, the development of sturgeon farming in Ukraine is not possible without the intensification of fish farming in general and increasing the efficiency of RAS in particular. In turn, achieving the results in these areas of aquaculture allows optimizing the feeding of fish with feed, in particular through the introduction of biologically active additives in the diet. For example, in the course of the study it was found that the introduction of inactivated baker's yeast into the diet of juvenile Russian sturgeon can improve the quality of fish, which is interconnected with the level of survival, and therefore interconnected with the number of individuals that can be sold at the end of the growing period, thereby affecting the profitability of production.

\section{HIGHLIGHT OF THE EARLIER UNRESOLVED PARTS OF THE GENERAL PROBLEM. AIM OF THE STUDY}

Improving the economic efficiency of measures to intensify fish farming in general, and the use of RAS in particular, necessitates the constant search for new methods and approaches to problems solving. The latter are mainly related to the quality and survival of juvenile fish, especially during its transition to compound feeding $[5,6]$. In turn, this encourages the improvement of existing feed formulations and experiments with biologically active additives.

The purpose of the study, based on the above, was to determine the main parameters of economic efficiency (prime cost, profitability) of inactivated baker's yeast, as a biologically active additive, in the diet of early juvenile Russian sturgeon. 


\section{MATERIALS AND METHODS}

The outlined calculations were performed according to generally accepted methods in economics. For the economic analysis, we used the actual parameters of economic activity in current industrial aquaculture of Ukraine based on the use of RAS, as well as the prices of 2015-2016 for the relevant materials, various types of products and means of production.

The material for assessing the cost-effectiveness of the introduction of inactivated baker's yeast in the diet were the early juveniles of Russian sturgeon, which were fed manually every 3 hours by this biologically active additive mixed with the main starter feed. In total, 2 series of experiments were performed. In the 1st series of the experiment, we investigated the efficiency of introduction of $10 \%$ and $40 \%$ (by weight of the main feed) of inactivated baker's yeast, in the 2 nd series - 5\% and $15 \%$. The duration of the experiment was 28 days, from 25 to 53 days from hatching.

Mathematical processing of the material was performed using MS Excel.

The calculation of the economic efficiency of growing Russian sturgeon was carried out according to the recommendations [7,8]. The economic effect was calculated by the formula:

$$
\begin{aligned}
& L P=\frac{\Pi}{3} \times 100, \text { where: } \\
& P \text { - level of profitability, } \% \\
& \Pi \text { - profit, UAH.; } \\
& 3 \text { - prime cost, costs associated with growing fish, UAH. }
\end{aligned}
$$

The structure of the prime cost of fish included the main costs associated with the production of products at fish farms [7-9].

\section{STUDY RESULTS AND THEIR DISCUSSION}

According to the results of the study of the cultivation of early juveniles of Russian sturgeon with the introduction of inactivated baker's yeast into the diet as a new method of intensification of fish farming, an economic assessment of their use at different concentrations was given. The calculation of the economic efficiency of the use of inactivated baker's yeast was based on the total cost of feeds, taking into account the partial replacement of feed with a biologically active additive - this microorganism.

Thus, it was found that under equal conditions (labor costs, feed and the number of fish stocking material) $40 \%$ replacement of feed weight by inactivated baker's yeast negatively affected the final results of cultivation, leading to lower a number of individuals sold compared to control (table 1).

At the same time, when $5 \%, 10 \%$ and $15 \%$ of feed weight were replaced by inactivated baker's yeast, the opposite result was observed - the number of individuals that could be sold at the end of the growing period increased relative to control. When comparing all studied options, the best result in the cultivation of early juveniles of Russian sturgeon was ensured by the use of $5 \%$ and $15 \%$ of inactivated baker's yeast in the main feed. 
ECONOMIC EFFICIENCY OF GROWING EARLY JUVENILES OF RUSSIAN STURGEON (ACIPENSER GUELDENSTAEDTII BRANDT \& RATZEBURG, 1833) WITH THE INTRODUCTION IN THE DIET INACTIVATED BAKER'S YEAST

Table 1. The cost of labor and material resources for the cultivation of early juveniles of Russian sturgeon with the introduction of inactivated baker's yeast into their diet

\begin{tabular}{|c|c|c|c|c|c|c|}
\hline \multirow[b]{2}{*}{ Indicators } & \multicolumn{3}{|c|}{ Experiment 2015} & \multicolumn{3}{|c|}{ Experiment 2016} \\
\hline & $\begin{array}{l}\text { Con- } \\
\text { trol } \\
\text { №1 }\end{array}$ & $\begin{array}{l}\text { Experimen- } \\
\text { tal group } \\
\text { №2 (10\% } \\
\text { yeast) }\end{array}$ & $\begin{array}{c}\text { Experimen- } \\
\text { tal group } \\
\text { №4 (40\% } \\
\text { yeast) }\end{array}$ & $\begin{array}{l}\text { Con- } \\
\text { trol } \\
\text { №2 }\end{array}$ & $\begin{array}{c}\text { Experimen- } \\
\text { tal group } \\
\text { №1 (5\% } \\
\text { yeast) }\end{array}$ & $\begin{array}{l}\text { Experimen- } \\
\text { tal group } \\
\text { №3 (15\% } \\
\text { yeast) }\end{array}$ \\
\hline $\begin{array}{l}\text { Purchased fish seeds, } \\
\text { larvae, individuals }\end{array}$ & 300 & 300 & 300 & 300 & 300 & 300 \\
\hline $\begin{array}{l}\text { Number of individuals } \\
\text { sold, individuals }\end{array}$ & 233 & 247 & 218 & 269 & 291 & 292 \\
\hline Feed supply: & & & & & & \\
\hline compound feed, g & 372.9 & 357.3 & 195.6 & 304.6 & 359.3 & 401.8 \\
\hline baker's yeast, $\mathrm{g}$ & - & 34.6 & 130.5 & - & 21.0 & 70.9 \\
\hline Labor costs, person & 2 & 2 & 2 & 2 & 2 & 2 \\
\hline
\end{tabular}

According to the conditions of production, i.e. use of a RAS, the largest (over $50 \%$ of the total) costs were associated with the purchase of fish seeds, the levers of influence on the price of which were almost absent (except when fish were grown at the same farm). Thus, in all variants of the experiments, the purchase costs of Russian sturgeon larvae ranged from 52.72\% (experimental group №4) to $55.45 \%$ (control group №2).

A similar situation was observed for other production costs, which included labor costs and electricity and water supplies - they were also determined by the general market conditions and ranged from $36.4 \%$ (experimental group №4) to $37.75 \%$ (control group №1) (Fig. 1).

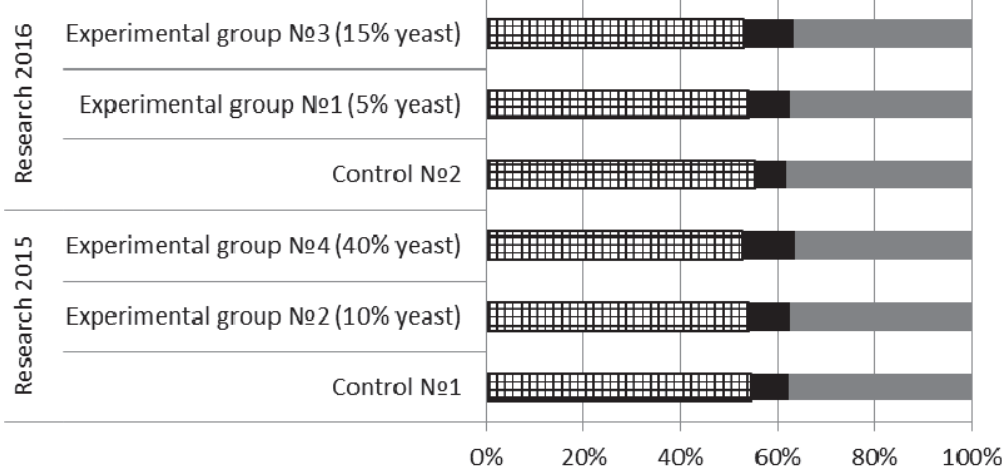

$\square$ The cost of fish stocking material (larvae), \%

- Feed costs, $\%$

- Other production costs, \%

Fig. 1. The ratio of the share of costs for fish seeds, feed and other production from the total, when growing juveniles of Russian sturgeon 
Instead, the share of feed costs can be adjusted by the producer, but not always reducing this cost item leaded to production optimization. For example, feed costs for growing juveniles of Russian sturgeon ranged from $6.25 \%$ (control group №2) to $10.88 \%$ (experimental group №4) and did not correlate with the quality of farmed individuals (Table 2).

Table 2. The prime cost of growing early juveniles of Russian sturgeon with the introduction of inactivated baker's yeast into their diet *

\begin{tabular}{|c|c|c|c|c|c|c|}
\hline \multirow[b]{2}{*}{ Indicators } & \multicolumn{3}{|c|}{ Experiment 2015} & \multicolumn{3}{|c|}{ Experiment 2016} \\
\hline & $\begin{array}{c}\text { Control } \\
\text { №1 }\end{array}$ & \begin{tabular}{|c|} 
Experi- \\
mental \\
group №2 \\
$(10 \%$ \\
yeast)
\end{tabular} & $\begin{array}{c}\text { Experi- } \\
\text { mental } \\
\text { group №4 } \\
\text { (40\% } \\
\text { yeast) }\end{array}$ & $\begin{array}{c}\text { Control } \\
\text { №2 }\end{array}$ & \begin{tabular}{|c|} 
Experi- \\
mental \\
group №1 \\
(5\% \\
yeast)
\end{tabular} & $\begin{array}{c}\text { Experi- } \\
\text { mental } \\
\text { group №3 } \\
\text { (15\% yeast) }\end{array}$ \\
\hline $\begin{array}{l}\text { The cost of fish seeds } \\
\text { (larvae), UAH / individuals }\end{array}$ & 0.9 & 0.9 & 0.9 & 0.9 & 0.9 & 0.9 \\
\hline $\begin{array}{l}\text { The cost of fish seeds } \\
\text { (larvae), UAH }\end{array}$ & $\frac{270}{54.7^{* *}}$ & $\frac{270}{54.2^{* *}}$ & $\frac{270}{52.72^{* *}}$ & $\frac{270}{55.45} *$ & $\frac{270}{54.0^{* *}}$ & $\frac{270}{53.04^{* *}}$ \\
\hline $\begin{array}{l}\text { The cost of } 1 \mathrm{~kg} \text { of } \\
\text { compound feed, UAH }\end{array}$ & 100 & 100 & 100 & 100 & 100 & 100 \\
\hline Total feed costs, UAH & $\frac{37.29}{7.55^{* *}}$ & $\frac{41.85}{8.4^{* *}}$ & $\frac{55.72}{10.88^{* *}}$ & $\frac{30.46}{6.25^{* *}}$ & $\frac{43.65}{8.73^{* *}}$ & $\frac{52.75}{10.36^{* *}}$ \\
\hline compound feed & 37.29 & 35.73 & 19.56 & 30.46 & 39.93 & 40.20 \\
\hline baker's yeast & - & 6.12 & 23.10 & - & 3.72 & 12.55 \\
\hline Salary, UAH & $\frac{118.6}{24.02^{* *}}$ & $\frac{118.6}{23.8^{* *}}$ & $\frac{118.6}{23.15^{* *}}$ & $\frac{118.6}{24.36^{* *}}$ & $\frac{118.6}{23.71^{* *}}$ & $\frac{118.6}{23.29 * *}$ \\
\hline $\begin{array}{l}\text { Wage taxes, UAH (19.5\% of } \\
\text { the wages) }\end{array}$ & $\frac{23.13}{4.68^{* *}}$ & $\frac{23.13}{4.64^{* *}}$ & $\frac{23.13}{4.51^{* *}}$ & $\underline{23.13}$ & $\frac{23.13}{4.62^{* *}}$ & $\frac{23.13}{4.54^{* *}}$ \\
\hline Electricity, UAH & $\frac{24.3}{4.92^{* *}}$ & $\frac{24.3}{4.87^{* *}}$ & $\frac{24.3}{4.74^{* *}}$ & $\frac{24.3}{4.99 * *}$ & $\frac{24.3}{4.85^{* *}}$ & $\frac{24.3}{4.77^{* *}}$ \\
\hline Water use, UAH & $\frac{16.8}{3.4^{* *}}$ & $\frac{16.8}{3.37^{* *}}$ & $\frac{16.8}{3.28^{* *}}$ & $\frac{16.8}{3.45^{* *}}$ & $\frac{16.8}{3.35^{* *}}$ & $\frac{16.8}{3.29^{* *}}$ \\
\hline Amortization & $\frac{3.56}{0.72^{* *}}$ & $\frac{3.56}{0.71^{* *}}$ & $\frac{3.56}{0.69^{* *}}$ & $\frac{3.56}{0.73^{* *}}$ & $\frac{3.56}{0.71^{* *}}$ & $\frac{3.56}{0.69^{* *}}$ \\
\hline In total, UAH & 493.68 & 498.24 & 512.11 & 486.85 & 500.04 & 509.14 \\
\hline
\end{tabular}

Note. * all financial calculations, except for the cost of feed made on the basis of the number of juveniles of Russian sturgeon in 50 thousand individuals;

** \% ratio to total costs of cultivation.

Thus, the largest (over 50\%) part of the cost of juveniles of Russian sturgeon was the cost of fish seeds, and the smallest (up to $11 \%$ ) - the cost of feeds. At the same time, among other production costs, the most significant, among other items, were deductions for wages. They ranged from $23.15 \%$ (experimental group №4) to $24.02 \%$ (control group №1). The cost of electricity was comparable to that of water use, ranging from $4.77 \%$ (experimental group №3) to 4.99\% (control group №2) versus 3.28\% (experimental group №4) and 3.45\% (control group №2), respectively. Amortization was the least of all the expenditure for growing early juveniles of Russian sturgeon in the RAS. 
Based on the above mentioned, the economic efficiency of the use of inactivated baker's yeast in the feeding early juveniles of Russian sturgeon determined the level of profitability (Table 3 ).

Table 3. Financial results of growing early juveniles of Russian sturgeon with the introduction of inactivated baker's yeast into their diet

\begin{tabular}{|l|c|c|c|c|c|c||}
\hline \multirow{2}{*}{ Indicators } & \multicolumn{4}{|c|}{ Experiment 2015 } & \multicolumn{3}{c||}{ Experiment 2016 } \\
\cline { 2 - 7 } & $\begin{array}{c}\text { Control } \\
\text { №1 }\end{array}$ & $\begin{array}{c}\text { Experi- } \\
\text { mental } \\
\text { group No2 } \\
\text { (10\% yeast) }\end{array}$ & $\begin{array}{c}\text { Experi- } \\
\text { mental } \\
\text { group No4 } \\
\text { (40\% yeast) }\end{array}$ & $\begin{array}{c}\text { Control } \\
\text { №2 }\end{array}$ & $\begin{array}{c}\text { Experi- } \\
\text { mental } \\
\text { group No1 } \\
\text { (5\% yeast) }\end{array}$ & $\begin{array}{c}\text { Experi- } \\
\text { mental } \\
\text { group №3 } \\
\text { (15\% yeast) }\end{array}$ \\
\hline $\begin{array}{l}\text { The cost of 1 individuals of } \\
\text { sturgeon, UAH }\end{array}$ & 3.0 & 3.0 & 3.0 & 3.0 & 3.0 & 3.0 \\
$\begin{array}{l}\text { Total spent, prime cost, } \\
\text { UAH }\end{array}$ & 493.68 & 498.24 & 512.11 & 486.85 & 500.04 & 509.14 \\
Attributable profit, UAH & 699.0 & 741.0 & 654.0 & 804.0 & 873.0 & 876.0 \\
$\begin{array}{l}\text { Net profit of total, UAH } \\
\text { The prime cost of 1 }\end{array}$ & 205.32 & 242.76 & 141.89 & 319.15 & 372.96 & 366.86 \\
individuals of sturgeon, & 2.12 & 2.01 & 2.35 & 1.81 & 1.72 & 1.74 \\
UAH & 41.59 & 48.72 & 27.7 & 65.14 & 74.59 & 72.01 \\
\hline \begin{tabular}{l} 
Profitability, \% \\
\hline
\end{tabular}
\end{tabular}

Thus, the level of profitability was directly related to the net profit and prime cost of 1 grown individuals of Russian sturgeon. A comparison of different feeding options for early juveniles of Russian sturgeon allows us to conclude that the highest (over $70 \%$ ) profitability can be achieved with the use of $5 \%$ and $15 \%$ of inactivated baker's yeast in the main feed, while increasing the share of this dietary supplement to $40 \%$ leads to lower rates, even for those in the control groups. A similar relationship was observed for net and other varieties of income.

Thus, the optimal ratio of basic feed and biologically active additives can increase the efficiency of RAS in general, and can indirectly contribute to the development of sturgeon farming in Ukraine, because it increases the profits and incomes of producers.

\section{CONCLUSION AND PERSPECTIVES OF FURTHER DEVELOPMENT}

Thus, the use of inactivated baker's yeast in the feeding of early juveniles of Russian sturgeon grown in RASs is economically feasible if the optimal ratio of this biologically active additive is chosen. The introduction of $5 \%$ and $15 \%$ of inactivated baker's yeast into the diet is cost-effective and economic efficient. These concentrations allow achieving a level of profitability of more than $70 \%$ and reduce the cost of 1 individual to 1.72-1.74 $\mathrm{UAH}$, thus providing, among other feeding options, such parameters as net (372.96 UAH and $366.86 \mathrm{UAH})$ and conditional profit (UAH 873.0 and UAH 876.0), taking into account that when they are used, the share of total feed costs increases to $8-10 \%$ versus $6-7 \%$ when fish are fed exclusively with a starting feed. 


\section{BIBLIOGRAPHY}

1. Козлов В. И., Козлов А. В. Осетроводство. Москва : МГУТУ, 2011. 336 с.

2. Муквич М. Г. Сучасний стан, проблеми та завдання розвитку рибництва в Україні // Рибогосподарська наука України. 2009. № 1. С. 4-8.

3. Стан запасів осетрових риб та розвиток осетрової аквакультури в Україні / Третяк О. М. та ін. // Рибогосподарська наука України. 2010. № 4. С. 4-22.

4. Симон М. Ю. Використання кормових дріжджів у годівлі осетрових видів риб (Acipenseridae) (Огляд) // Рибогосподарська наука України. 2015. № 4(34). С. $100-126$.

5. Третяк О. М. Економічна ефективність ставового рибництва з використанням у полікультурі американського веслоноса // Рибогосподарська наука України. 2010. № 1. С. 112-122.

6. Механізми забезпечення прибутковості рибних господарств України / Смирнюк Н. І. та ін. // Рибогосподарська наука України. 2009. № 1. С. 107115.

7. Лукошкин С. А., Казанов Д. Х. Основные технико-экономические показатели, применяемые в рыбном хозяйстве. Москва : Пищевая промышленность, 1977. $88 \mathrm{c.}$

8. Фридман И. Л. Методические рекомендации по определению экономического эффекта мероприятий по рыбоводству и сырьевой базе пресноводных водоёмов. Ленинград : ГосНИОРХ, 1986. 87 с.

9. Мошенський С. 3., Олійник О. В. Економічний аналіз. Житомир : Рута, 2007. $704 \mathrm{c}$.

\section{REFERENCES}

1. Kozlov, V. I., \& Kozlov, A. V. (2011). Osetrovodstvo. Moskva: MGUTU.

2. Mukvych, M. H. (2009). Suchasnyi stan, problemy ta zavdannia rozvytku rybnytstva v Ukraini. Rybohospodarska nauka Ukrainy, 1, 4-8.

3. Tretiak, O. M., et al. (2010). Stan zapasiv osetrovykh ryb ta rozvytok osetrovoi akvakultury v Ukraini. Rybohospodarska nauka Ukrainy, 4, 4-22.

4. Simon, M. Yu. (2015). Vykorystannia kormovykh drizhdzhiv u hodivli osetrovykh vydiv ryb (Acipenseridae) (Ohliad). Rybohospodarska nauka Ukrainy, 4(34), 100126.

5. Tretiak, O. M. (2010). Ekonomichna efektyvnist stavovoho rybnytstva z vykorystanniam u polikulturi amerykanskoho veslonosa. Rybohospodarska nauka Ukrainy, 1, 112-122.

6. Smyrniuk, N. I., et al. (2009). Mekhanizmy zabezpechennia prybutkovosti rybnykh hospodarstv Ukrainy. Rybohospodarska nauka Ukrainy, 1, 107-115.

7. Lukoshkin, S. A., \& Kazanov, D. Kh. (1977). Osnovnye tekhniko-ekonomicheskie pokazateli, primenyaemye $v$ rybnom khozyaystve. Moskva: Pishchevaya promyshlennost's.

8. Fridman, I. L. (1986). Metodicheskie rekomendatsii po opredeleniyu ekonomicheskogo effekta meropriyatiy po rybovodstvu $i$ syr'evoy baze presnovodnykh vodoemov. Leningrad : GosNIORKh.

9. Moshens'kiy, S. Z., \& Oliynik, O. V. (2007). Ekonomichniy analiz. Zhitomir: Ruta. 


\title{
СТОРІНКА МОЛОДОГО ВЧЕНОГО
}

Ribogospod. nauka Ukr., 2020; 2(52): 86-96

DOI: https://doi.org/10.15407/fsu2020.02.086

УДК 639.3.043.2:639.371.52
Received 27.04.20

Received in revised form 23.05.20

Accepted 05.06.20

\section{PRODUCTIVE AND ECONOMIC EFFICIENCY OF REARING TABLE CARP WITH THE USE OF NON-TRADITIONAL FEED ADDITIVES}

\author{
O. Baturevych, shtefan91@ukr.net, Institute of Fisheries NAAS, Kyiv \\ T. Bersan, bersanto@ukr.net, Institute of Fisheries NAAS, Kyiv
}

Purpose. To establish the efficiency of the use of such minerals assaponite, analcime and bentonite used as feed additives in the main diet of age-1+ carp on their majorfeatures and the economic component of their cultivation in ponds.

Methodology. The experimental works were carried out in the conditions of ponds of the State Enterprise ExperimentalFarm "Nyvka" of the Institute of Fisheries of NAAS during the growing period of 2018. The object of the study were age-1+carp of Nyvka scaly intrabreed type. The study included three experimental and control groups of fish and was conducted in analogous ponds with an area of 0.5 ha each. The diet of fish of the first experimental group ws supplemented with $3 \%$ of saponite, the diet of fish of the second experimental group was supplemented with $3 \%$ of analcime, and the diet of fish of the third experimental group was supplemented with $2 \%$ of bentonite. The control group of fish was fed with a balanced feed, without additives. Hydrochemical and fish farming studies were carried out according to generally accepted methods.

Findings. The study demonstrated that majorhydrochemical parameters during the growing period were within normal limits, but there was an increase in the level of permanganate oxidation of waterwith an increase in water temperature during the summer. However, the level of chlorides was slightly increased during the entire growingseason in the experimental and control ponds.

In the experimental variants, when supplanting the main diet of age-1+ carp with saponite, analcime and bentonite, the total fish productivity of ponds was higher by $0.7 \%, 13.4 \%$ and $3.5 \%$, respectively, with a decrease in feed costs for cultivation compared to control. At the same time, the best survival rate of fish was $69.1 \%$ when fish were fed with the feed supplemented with bentonite, versus $64.2 \%$ in the control pond.

When analyzing the economic efficiency of the use of these minerals in the feeding of age-1+ carp, a 2\% increase in profitability was observed as a result of the supplementation of fish diet with saponite, $16.4 \%$ after addinganalcime and $4.2 \%$ after adding bentonite compared to control.

As a result of comparative characteristics of the studied minerals, it should be noted that the most promising for use in the feeding of age-1+carp can be analtsim, given the highest rates of weight gain of fish, fish productivity of ponds and as well as the earned profit.

Originality. The efficiency of the use of such minerals as saponite, analcime and bentonite in the feeding of age-1+ carp as non-traditional feed additives was analyzed for the first time. A comparative assessment of their effects on the main fish features and economic parameters of cultivation was performed.

Practical value. Based on obtained positive results of the introduction of the studied minerals into the diet of carp, it is possible to increase fish growth and fish productivity of ponds. The low cost of these non-traditional additives leads to a positive economic effect in the process of fish cultivation. Accordingly, the use of saponite, analcime and bentonite in the conditions of commercial carp cultivation is justified and relevant.

Key words: age-1+ carp, saponite, analcime, bentonite, minerals of natural origin, fish productivity, economic efficiency.

(C) O. Baturevych, T. Bersan, 2020 


\section{ПРОДУКТИВНА ТА ЕКОНОМІЧНА ЕФЕКТИВНІСТЬ ВИРОЩУВАННЯ ТОВАРНОГО КОРОПА ЗА ВИКОРИСТАННЯ В ГОДІВЛІ НЕТРАДИЦІЙНИХ КОРМОВИХ ДОБАВОК}

О. О. Батуревич, shtefan 91@ukr.net, Інститут рибного господарства НАAН, м. Київ т. О. Берсан, bersanto@ukr.net, Інститут рибного господарства НАAН, м. Київ

Мета. Встановлення ефективності застосування мінералів сапоніт, анальцим $i$ бентоніт в якості кормових добавок у складі основного раціону дволіток коропа та впливу на основні рибогосподарські показники та економічну складову вирощування в умовах ставів.

Методика. Експериментальні роботи проведено в умовах ставів ДП ДГ «Нивка» Інституту рибного господарства НААН впродовж вегетаційного періоду 2018 року. Об'єктом дослідження були дволітки нивківського лускатого внутрішньопородного типу коропа. Дослідження складалося з трьох дослідних та контрольної груп риб і було проведене в ставах-аналогах площею 0,5 га кожен. Рибам першої дослідною групи до складу основного раціону вводили сапоніт у кількості 3\% в складі корму, рибам другої дослідної групи - 3\% анальциму, а рибам третьої дослідної групи - 2\% бентоніту. Контрольній групі риб згодовували збалансований комбікорм без введення до його складу добавок. Гідрохімічні $i$ рибницькі дослідження проводили за загальноприйнятими методиками.

Результати. У результаті проведених досліджень встановлено, що впродовж періоду вирощування основні гідрохімічні показники знаходилися у межах норми, проте при підвищенні температури води у літній період відмічено зростання рівня перманганатної окиснюваності води. Разом з тим, протягом всього вегетаційного сезону у дослідних та контрольному ставах рівень хлоридів був дещо підвищений.

у дослідних варіантах при введенні до складу основного раціону дволіток коропа сапоніту, анальциму та бентоніту загальна рибопродуктивність ставів була вищою відповідно на 0,7, 13,4 та 3,5\%, разом зі зниженням витрат кормів на вирощування в порівнянні з контролем. Поряд з цим, найкращий показник рівня виживання риб становив 69,1\% при годівлі їх кормом із додаванням бентоніту, проти 64,2\% у контрольному ставу.

Аналізуючи економічну ефективність використання даних мінералів у годівлі дволіток коропа, слід зазначити збільшення рівня рентабельності на 2\% у результаті введення до складу раціону риб сапоніту, на 16,4\% - анальциму та на 4,2\% - бентоніту відносно контролю.

За результатами порівняння характеристик досліджуваних мінералів, слід зазначити, що найперспективнішим для використання в годівлі дволіток коропа може бути анальцим, з огляду на найвищі показники приросту маси риб, рибопродуктивності ставів та отриманого прибутку.

Наукова новизна. В результаті експерименту вперше проаналізовано ефективність використання мінералів сапоніт, анальцим та бентоніт в годівлі дволіток коропа в якості нетрадиційних кормових добавок. Здійснено порівняльну оцінку їхнього впливу на основні рибогосподарські та економічні показники вирощування.

Практична значимість. На основі отриманих позитивних результатів введення досліджуваних мінералів до раціону коропа, можна забезпечити збільшення приростів риб та рибопродуктивності ставів. Невисока вартість даних нетрадиційних добавок зумовлює отримання позитивного економічного еректу в процесі вирощування. Відповідно, використання сапоніту, анальциму та бентоніту в умовах товарного вирощування коропа $\epsilon$ обгрунтованим і актуальним.

Ключові слова: дволітки коропа, сапоніт, анальцим, бентоніт, мінерали природного походження, рибопродуктивність, економічна ефективність. 


\title{
ПРОДУКТИВНАЯ И ЭКОНОМИЧЕСКАЯ ЭФФЕКТИВНОСТЬ ВЫРАЩИВАНИЯ ТОВАРНОГО КАРПА ПРИ ИСПОЛЬЗОВАНИИ В КОРМЛЕНИИ НЕТРАДИЦИОННЫХ КОРМОВЫХ ДОБАВОК
}

\author{
О. А. Батуревич, shtefan 91@ukr.net, Институт рыбного хозяйства НААН Украины, \\ г. Киев
}

T. А. Берсан, bersanto@ukr.net, Институт рыбного хозяйства НААН Украины, г. Киев

Цель. Определение эффективности применения минералов сапонит, анальцим и бентонит в качестве кормовых добавок в составе основного рациона двухлеток в контексте на основные рыбохозяйственные показатели и экономическую составляющую при выращивании в прудовых условиях.

Методика. Экспериментальные работы проведены в условиях прудов ГП ОХ «Нивка» Института рыбного хозяйства НААН в течение вегетационного периода 2018 года. Объектом исследования были двухлетки нивчанского чешуйчатого внутрипородного типа карпа. Исследование состояло из трех опытных и контрольной групп рыб и было проведено в прудах-аналогах площадью 0,5 га каждый. Рыбам первой опытной группы в состав основного рациона добавляли сапонит в количестве 3\% в составе корма, рыбам второй опытной группы - 3\% анальцима, а рыбам третьей опытной группы - 2\% бентонита. Контрольной группе рыб скармливали сбалансированный комбикорм без введения в его состав добавок. Гидрохимические и рыбоводные исследования проводили по общепринятым методикам.

Результаты. В результате проведенных исследований установлено, что в течении периода выращивания основные гидрохимические показатели находились в пределах нормы, однако при повышении температуры воды в летний период отмечен рост уровня перманганатной окисляемости воды. Вместе с тем, в течение всего вегетационного сезона в опытных и контрольном прудах уровень хлоридов был несколько повышен.

В опытных вариантах при введении в состав основного рациона двухлеток карпа сапонита, анальцима и бентонита общая рыбопродуктивность прудов была выше соответственно на 0,7, 13,4 и 3,5\%, вместе со снижением затрат кормов на выращивание по сравнению с контролем. Наряду с этим, лучший показатель выживаемости рыб составил 69,1\% при кормлении рыб кормом с добавлением бентонита, против 64,2\% в контрольном пруду.

Анализируя экономическую эфрективность при использовании данных минералов в кормлении двухлеток карпа, следует отметить повышение уровня рентабельности на $2 \%$ в результате введения в состав рациона рыб сапонита, на 16,4\% - анальцима и на 4,2\% бентонита по отношению к контролю.

По результатам сравнения характеристик исследуемых минералов, следует отметить, что наиболее перспективным для использования в кормлении двухлеток карпа может быть анальцим, учитывая высокие показатели прироста массы рыб, рыбопродуктивности прудов и полученной прибыли.

Научная новизна. В результате эксперимента впервые проанализирована эффрективность использования минералов сапонит, анальцим и бентонит в кормлении двухлеток карпа в качестве нетрадиционных кормовых добавок. Осуществлена сравнительная оценка их влияния на основные рыбохозяйственные и экономические показатели выращивания.

Практическая значимость. На основе полученных положительных результатов введения исследуемых минералов в рацион карпа, можно обеспечить увеличение приростов рыб и рыбопродуктивности прудов. Невысокая стоимость данных нетрадиционных добавок приводит к получению положительного экономического эффекта в процессе выращивания. Соответственно, использование сапонита, анальцима и бентонита в условиях товарного выращивания карпа является обоснованным и актуальным.

Ключевые слова: двухлетки карпа, сапонит, анальцим, бентонит, минералы природного происхождения, рыбопродуктивность, экономическая эффективность. 


\section{PROBLEM STATEMENT AND ANALYSIS OF LAST ACHIEVEMENTS AND PUBLICATIONS}

Nowadays, in the conditions of market economy of the state, there is a need to identify reserves for the development of fish industry and to search for new economically sound approaches to management. The priority tasks of fish farming are: reducing the cost of technologies, resource saving, improving the quality and ensuring the competitiveness of fish products while increasing productivity and ensuring environmental safety [1]. The task of optimizing and reducing the cost of production of final products requires additional costs and cannot always guarantee an effective increase in fish productivity. Therefore, one of the main areas of competitiveness in the market of fish products is fish feeding because the majority of the cost in the process of fish cultivation falls on feeds [2].

In this regard, it is of great interest to use non-traditional feed additives in fish feeding that can satisfy the needs of fish not only in nutrients but also in minerals, which ensures the normal growth and development of fish body [3]. Therefore, due to the positive results in the field of fish farming [4], such additives can be natural minerals with sorption properties -saponite, analcime and bentonite. Scientific studies demonstrated that the use of these minerals of natural origin in the diet of farm animals and poultry has a positive effect on the physiological state of their body and productivity $[5,6]$. The high efficiency of their use is due to the content of approximately forty macro- and microelements, as well as adsorption, ion exchange and catalytic characteristics [7, 8]. Especially important for fish farming is the property of these minerals to sorb mycotoxins in finished feed and to slow down the passage of feed into the intestines of fish depending on the temperature that has a positive effect on the digestibility of feed [9-10].

\section{HIGHLIGHT OF THE EARLIER UNRESOLVED PARTS OF THE GENERAL PROBLEM. AIM OF THE STUDY}

According to their physicochemical properties, the use of these minerals in the cap feeding in ponds is a very promising task. Analcime, saponite and bentonite are littlestudied mineral additives in fish farming; however, our previous studies showed the effectiveness of their use in feeding age-1+ and brood carp [11-12]. At the same time, other authors studied the use of bentonites in the feeding of sturgeon and trout $[6,13]$, which is of considerable scientific interest for further studies in fish industry.

The study examines the feasibility of the use of these additives in the feeding of age-1+ carp with a purpose of increasing fish productivity of ponds and establishing the economic efficiency of fish cultivation.

The aim of the study was to determine the efficiency of the use of analcime, saponite and bentonite in the feeding of age-1+ carp in terms of productivity, feed consumption and economic component of fish cultivation.

\section{MATERIALS AND METHODS}

The study was carried out in the conditions of the State Enterprise Experimental Farm "Nyvka" of the Institute of Fisheries of NAAS. Three experimental ponds and one control pond with an area of 0.5 ha each were used in the experiment. The object of the study were age-1+ carp of Nyvka scaly intrabreed type. The stocking density of the 
experimental groups of fish was 4000 specimens/ha. Fish of the first experimental group (Experiment 1) were fed during the growing period with a feed supplemented with $3 \%$ saponite, the diet of fish of the second experimental group (Experiment 2) included 3\% analcime, the diet of fishof the third experimental group (Experiment 3) included $2 \%$ bentonite. Fish of the control group (Control) was fed with the compound feed PKS 111-2/2/4, manufactured at the Dnepropetrovsk plant of fish feed. In total, the growing season lasted 120 days, from May 14 to September 10, 2018. Feeds were introduced into ponds to the feeding places from the shoreline once a day. The daily amount of feed was $3-5 \%$ of the weight of fish, taking into account the growth rate and hydrochemical regime. Feeding of carp was carried out according to the established feeding schemes [14] with semi-intensive technology of fish farming. Water sampling for chemical analysis and their processing in the laboratory were performed according to conventional hydrochemical methods. Water quality was assessed according to general requirements and regulations in fish farming [11 - 12]. At the end of the experimental work, fish were caught, their total and average weight were measured, the survival rate was calculated in accordance with the objectives set at the beginning of the study.

\section{STUDY RESULTS AND THEIR DISCUSSION}

Water temperature in the ponds was optimal for fish farming and reached its highest values in mid-July and early August $-26.0-27.5^{\circ} \mathrm{C}$.

The chemical composition of water was monitored during the growing period in the experimental and control ponds with the determination of the content of nutrients, organic matter and salt composition. No significant differences in the chemical composition of water were recorded in the experimental ponds because they hadthe same source of water supply (Table 1).

Table 1. Chemical analysis of water of experimental ponds during growing season of 2018, State Enterprise Experimental Farm "Nyvka" of the Institute of Fisheries NAAS (min-max /average)

\begin{tabular}{|c|c|c|c|c|c|}
\hline Parameters & Control & Experiment 1 & $\begin{array}{l}\text { Experiment } \\
\quad 2\end{array}$ & $\begin{array}{l}\text { Experiment } \\
\quad 3\end{array}$ & $\begin{array}{l}\text { Normative } \\
\text { value [16] }\end{array}$ \\
\hline \multirow{2}{*}{$\mathrm{pH}$} & 7.3-8.3 & 7.6-8.1 & $\underline{6.9-8.0}$ & 7.1-8.3 & \multirow{2}{*}{$6.5-8.5$} \\
\hline & 7.8 & 7.9 & 7.5 & 7.7 & \\
\hline \multirow{2}{*}{$\begin{array}{l}\text { Free ammonium, } \mathrm{NH}_{3}, \\
\mathrm{mgN} / \mathrm{dm}^{3}\end{array}$} & $\underline{0.00-0.05}$ & $\underline{0.01-0.05}$ & $\underline{0.00-0.06}$ & $\underline{0.00-0.05}$ & \multirow{2}{*}{0.05} \\
\hline & 0.025 & 0.03 & 0.03 & 0.025 & \\
\hline \multirow{2}{*}{$\begin{array}{l}\text { Permanganate oxidation, } \\
\mathrm{mgO} / \mathrm{dm}^{3}\end{array}$} & $\underline{10.6-23.9}$ & $\underline{13.2-20.1}$ & $\underline{9.8-22.4}$ & $\underline{11.1-20.8}$ & \multirow{2}{*}{15} \\
\hline & 17.3 & 16.7 & 16.1 & 16.0 & \\
\hline \multirow{2}{*}{$\begin{array}{l}\text { Ammonium nitrogen, } \mathrm{NH} \\
{ }_{4+}, \mathrm{mgN} / \mathrm{dm}^{3}\end{array}$} & $\underline{0.03-0.64}$ & $\underline{0.02-0.51}$ & $\underline{0.03-0.60}$ & $\underline{0.01-0.52}$ & \multirow{2}{*}{2.0} \\
\hline & 0.335 & 0.256 & 0.315 & 0.265 & \\
\hline \multirow{2}{*}{ Nitrites, $\mathrm{NO}_{2-}, \mathrm{mgN} / \mathrm{dm}^{3}$} & $\underline{0.01-0.05}$ & $\underline{0.01-0.05}$ & $\underline{0.00-0.04}$ & $\underline{0.02-0.04}$ & \multirow{2}{*}{0.100} \\
\hline & 0.03 & 0.03 & 0.02 & 0.03 & \\
\hline \multirow{2}{*}{ Nitrates, $\mathrm{NO}_{3}{ }^{-}, \mathrm{mgN} / \mathrm{dm}^{3}$} & $\underline{0.01-0.24}$ & $\underline{0.00-0.22}$ & $\underline{0.01-0.19}$ & $\underline{0.00-0.22}$ & \multirow{2}{*}{ up to 2.0} \\
\hline & 0.13 & 0.11 & 0.1 & 0.11 & \\
\hline
\end{tabular}




\begin{tabular}{|c|c|c|c|c|c|}
\hline \multicolumn{6}{|c|}{ Continuation of the table. 1} \\
\hline Parameters & Control & $\begin{array}{l}\text { Experiment } \\
\quad 1\end{array}$ & $\begin{array}{c}\text { Experiment } \\
2\end{array}$ & $\begin{array}{l}\text { Experiment } \\
\quad 3\end{array}$ & \begin{tabular}{|c|} 
Norma- \\
tive value \\
{$[16]$}
\end{tabular} \\
\hline $\begin{array}{l}\text { Mineral phosphorus, } \mathrm{PO}^{3-} \text {, } \\
\mathrm{mgP} / \mathrm{dm}^{3}\end{array}$ & $\frac{0.02-0.15}{0.09}$ & $\frac{0.02-0.16}{0.09}$ & $\frac{0.01-0.14}{0.08}$ & $\frac{0.02-0.22}{0.12}$ & 0.7 \\
\hline $\begin{array}{l}\text { Total iron, } \mathrm{Fe}^{2+}+\mathrm{Fe}^{3+}, \\
\mathrm{mgFe} / \mathrm{dm}^{3}\end{array}$ & $\frac{0.22-0.36}{0.29}$ & $\frac{0.26-0.41}{0.34}$ & $\frac{0.24-0.42}{0.33}$ & $\frac{0.24-0.39}{0.32}$ & 1.0 \\
\hline Calcium, $\mathrm{Ca}^{2+}, \mathrm{mg} / \mathrm{L}$ & $\frac{50.0-55.2}{52.6}$ & $\frac{48.4-50.4}{49.4}$ & $\frac{36.2-42.8}{39.5}$ & $\frac{33.1-51.7}{42.4}$ & $40-60$ \\
\hline Magnesium, $\mathrm{Mg}^{2+}, \mathrm{mg} / \mathrm{dm}^{3}$ & $\frac{8.4-12.8}{10.6}$ & $\frac{10.0-12.1}{11.0}$ & $\frac{3.2-13.2}{8.2}$ & $\frac{2.3-12.4}{7.4}$ & $\leq 30$ \\
\hline $\begin{array}{l}\text { Sodium + potassium, } \mathrm{Na}^{+}+ \\
\mathrm{K}^{+}, \mathrm{mg} / \mathrm{dm}^{3}\end{array}$ & $\frac{77.6-104.8}{91.2}$ & $\frac{60.2-100.2}{80.2}$ & $\frac{81.1-102.1}{91.6}$ & $\frac{50.4-104.0}{77.2}$ & 50 \\
\hline $\begin{array}{l}\text { Hydrocarbonates, } \mathrm{HCO}_{3-,} \\
\mathrm{mg} / \mathrm{dm}^{3}\end{array}$ & $\frac{120.0-146.5}{133.3}$ & $\frac{113.4-140.2}{126.8}$ & $\frac{132.1-143.4}{137.8}$ & $\frac{121.0-136.8}{128.9}$ & $300-400$ \\
\hline Chlorides, $\mathrm{Cl}-, \mathrm{mg} / \mathrm{dm}^{3}$ & $\frac{71.4-163.9}{117.7}$ & $\frac{55.2-159.4}{107.3}$ & $\frac{60.0-147.4}{103.7}$ & $\frac{112.4-156.1}{134.3}$ & $50-70$ \\
\hline Sulfates, $\mathrm{SO}^{2-}, \mathrm{mg} / \mathrm{dm}^{3}$ & $\frac{31.4-47.3}{39.4}$ & $\frac{30.2-49.0}{39.6}$ & $\frac{29.6-44.2}{36.9}$ & $\frac{33.0-41.4}{37.2}$ & $50-70$ \\
\hline Hardness, mg-eq. $/ \mathrm{dm}^{3}$ & $\frac{2.1-3.8}{2.9}$ & $\frac{2.3-4.1}{3.2}$ & $\frac{2.8-3.9}{3.4}$ & $\frac{2.2-3.8}{3.0}$ & $5-7$ \\
\hline Mineralization, $\mathrm{mg} / \mathrm{dm}^{3}$ & $\frac{447.1-530.4}{488.8}$ & $\frac{485.0-515.6}{500.3}$ & $\frac{490.6-522.7}{506.7}$ & $\frac{414.8-540.0}{477.4}$ & 1000 \\
\hline
\end{tabular}

The $\mathrm{pH}$ was in the range of $6.9-8.3$ that was an acceptable normal value for fish ponds. Free ammonia was absent at the beginning of the season and increased to 0.06 $\mathrm{mgN} / \mathrm{dm}^{3}$ in late July, indicating an intensification of algal blooms. As for permanganate oxidation, its increase indicates the presence of easily oxidizable organic compounds in water. Thus, the lowest average value during the seasonwas 16.0 $\mathrm{mgO} / \mathrm{dm}^{3}$ in Experiment 3. This value was the highest in the control $-17.3 \mathrm{mgO} / \mathrm{dm}^{3}$. The average value of water oxidation in all ponds generally exceeded the normal limits, which indicates increased water pollution by organic matter.

As for the dynamics of changes in nutrients, it was found that ammonium nitrogen and mineral phosphorus were present in all experimental and control ponds, but in small quantities, which were acceptable for fish farming. The average seasonal index of nitrite nitrogen ranged from 0.02 to $0.03 \mathrm{mgN} / \mathrm{dm}^{3}$, which did not exceed the normative values. Nitrate nitrogen was absent or present in minimal amounts in all ponds at the beginning of the season and increased in late July to a maximum of $0.24 \mathrm{mgN} / \mathrm{dm}^{3}$, which may indicate the active development of phytoplankton in the ponds. However, its average seasonal content ranged from 0.1 to $0.13 \mathrm{mgN} / \mathrm{dm}^{3}$, which did not exceed the established standards.

The content of total iron during the season varied, ranging from 0.22 to 0.42 $\mathrm{mgFe} / \mathrm{dm}^{3}$, which did not exceed the normative values in all ponds. Water of the experimental ponds was characterized by almost the same average hardness, slowly 
increasing until the middle of the season $\left(2.1-4.1 \mathrm{mg}-\mathrm{eq} / \mathrm{dm}^{3}\right)$, respectively, and the calcium content was within the normative values with slightly lower values in Experiment 2.

Water contamination with chlorides during cultivation was observed. On average, their content ranged from 55.2 to $163.9 \mathrm{mg} / \mathrm{dm}^{3}$, which significantly exceeded the normative values $\left(50-70 \mathrm{mg} / \mathrm{dm}^{3}\right)$.

The average seasonal sulfate concentration ranged from 36.9 to $39.6 \mathrm{mg} / \mathrm{dm}^{3}$ in Experiment 2 and Experiment 1, respectively, which did not exceed the normative values.

The total hardness and mineralization of water of the studied ponds were characterized by the average value of acceptable concentrations and belonged to the hydrocarbonate class according to the classification of O.O. Alekin [15].

Thus, the chemical composition of water in the experimental ponds during the study period differed little because of having the same source of water supply. However, there was an increased content of chlorides in the water of all ponds throughout the season and an increase in permanganate oxidation compared to the normative values at the end of the growing season.

After the autumn harvests of experimental and control ponds, the major fish features were analyzed, which showed that the fish survival rate was highest in Experiment 3 (69.1\%)when fish were fed witha feed supplemented with bentonite (Table 2). The lowest survival rate was observed in Experiment $1(60 \%)$, where fish were fed with a feed supplemented with saponite. The average weight of farmed carp was $162.5 \mathrm{~g}$ in Experiment 1, where fish diet was supplemented with saponite, which was $9.2 \%$ more than in Control, $166 \mathrm{~g}$ in Experiment 2 where fish were fed with a feed supplemented with analzyme, which is higher than the control by $11.5 \%$, and $141.8 \mathrm{~g}$ in Experiment 3, where fish were fed with a feed supplemented with bentonite. As for the survival rate and weight of harvested carp, the fish productivity of all experimental ponds was higher compared to Control. Thus, fish productivity in Experiment 1 was $284 \mathrm{~kg} / \mathrm{ha}, 320 \mathrm{~kg} / \mathrm{hain}$ Experiment 2 and $292 \mathrm{~kg} / \mathrm{ha}$ in Experiment 3 versus $282 \mathrm{~kg} / \mathrm{ha}$ in Control that washigher by $0.7 \%, 13,4 \%$ and $3.5 \%$, respectively.

Table 2. The results of growing age-1+ carp fed with a feed supplemented with bentonite, saponite and analcime during the growing season

\begin{tabular}{|c|c|c|c|c|c|c|c|c|c|c|}
\hline \multirow[b]{2}{*}{$\begin{array}{l}\text { Fish } \\
\text { groups }\end{array}$} & \multirow[b]{2}{*}{$\begin{array}{c}\text { Pond } \\
\text { area, } \\
\text { ha }\end{array}$} & \multicolumn{3}{|c|}{ Stocked } & \multicolumn{4}{|c|}{ Harvested } & \multirow{2}{*}{$\begin{array}{l}\text { Fish } \\
\text { pro- } \\
\text { duc- } \\
\text { tivity, } \\
\text { kg/ha }\end{array}$} & \multirow[b]{2}{*}{$\begin{array}{l}\text { Feed } \\
\text { costs. } \\
\text { units }\end{array}$} \\
\hline & & $\begin{array}{l}\text { quan- } \\
\text { tity, } \\
\text { ind. }\end{array}$ & $\begin{array}{l}\text { ave. } \\
\text { weight, } \\
\text { rg }\end{array}$ & $\begin{array}{c}\text { total } \\
\text { weight, } \\
\text { kg }\end{array}$ & $\begin{array}{c}\text { yield, } \\
\%\end{array}$ & $\begin{array}{l}\text { quanti } \\
\text { ty, ind. }\end{array}$ & $\begin{array}{c}\text { ave. } \\
\text { weight, } \\
\text { rg }\end{array}$ & $\begin{array}{c}\text { total } \\
\text { weight, } \\
\text { kg }\end{array}$ & & \\
\hline Control & 0.5 & 2000 & 25 & 50 & 64.2 & 1284 & 148.8 & 191 & 282 & 6.4 \\
\hline $\begin{array}{l}\text { Experi- } \\
\text { ment } 1\end{array}$ & 0.5 & 2000 & 25 & 50 & 60.0 & 1200 & 162.5 & 195 & 284 & 6.2 \\
\hline $\begin{array}{l}\text { Experi- } \\
\text { ment } 2\end{array}$ & 0.5 & 2000 & 25 & 50 & 66.9 & 1338 & 166 & 210 & 320 & 5.7 \\
\hline $\begin{array}{l}\text { Experi- } \\
\text { ment } 3\end{array}$ & 0.5 & 2000 & 25 & 50 & 69.1 & 1382 & 141.8 & 196 & 292 & 6.2 \\
\hline
\end{tabular}


As for the cost of feeds for fish production, these parameters were the highest in the Control and amounted to 6.4 units, they were slightly lower in the experimental groups: 6.2 unitsin Experiment 1 and 3, 5.7 unitsin Experiment 2.

Thus, when comparing the results of the obtained fish productivity, it can be noted that its best valueswere demonstrated in Experiment 2, where fish received analcime in their diet.

When assessing the efficiency of aquaculture enterprises, attention should be paid to increasing profitable potential not only by increasing prices or productivity, but also to reducing the cost of the product through targeted measures to optimize feeding or improving the diet of fish. In this regard, the analysis of the effectiveness of the use of minerals of natural origin in the feeding of age- $1+$ carp, primarily aimed at determining the level of profitability of their introduction into the main diet.

Thus, the profit from cultivation was calculated as the difference between the market value of the grown products and the total value of fish feed, feed additives and fish seeds used for cultivation, as these costs are basic. Other total farm costs cannot be divided on these experimental ponds due to their small area, so we consider them equal in all variants, as ponds of the same area with the same amount of fish stocked for farming were used.

The cost of feed per $1 \mathrm{~kg}$ of grown products was the lowest in Experiment 2, where fish were fed with a feed supplemented with analcime - 17.9 UAH. In Experiment 1, these costs amounted to 19.2 UAH, in Experiment 3 -18.8 UAH. In Control, this amount was 19 UAH (Table 3).

Table 3. Economic efficiency of using feeds supplemented with saponite, analcime and bentonite when growing age-1+ carp

\begin{tabular}{|c|c|c|c|c|c|}
\hline \multicolumn{2}{|c|}{ Fish group } & Control & Experiment 1 & Experiment 2 & Experiment 3 \\
\hline \multicolumn{2}{|l|}{ Pond area, ha } & 0.5 & 0.5 & 0.5 & 0.5 \\
\hline \multicolumn{2}{|l|}{ Fish yield, kg } & 191 & 195 & 210 & 196 \\
\hline \multirow{5}{*}{$\begin{array}{l}\text { Feed costs*, } \\
\text { UAH. }\end{array}$} & Combined feed & 3620 & 3620 & 3620 & 3620 \\
\hline & Saponite & - & 116 & - & - \\
\hline & Analcime & - & - & 132 & - \\
\hline & Bentonite & - & - & - & 66 \\
\hline & Total & 3620 & 3736 & 3752 & 3686 \\
\hline \multicolumn{2}{|c|}{$\begin{array}{l}\text { Feed costs per } 1 \mathrm{~kg} \text { of obtained } \\
\text { product, UAH }\end{array}$} & 19 & 19.2 & 17.9 & 18.8 \\
\hline \multicolumn{2}{|c|}{ Fish seed costs**, UAH } & 1750 & 1750 & 1750 & 1750 \\
\hline \multicolumn{2}{|c|}{$\begin{array}{l}\text { Market cost of obtained } \\
\text { product***, UAH }\end{array}$} & 9550 & 9750 & 10500 & 9800 \\
\hline \multicolumn{2}{|c|}{$\begin{array}{l}\text { Attributable profit (based on feed } \\
\text { and fish seed costs), UAH /ha }\end{array}$} & 4180 & 4264 & 4998 & 4364 \\
\hline \multicolumn{2}{|c|}{ Profit relative to Control,\% } & - & 2.0 & 16.4 & 4.2 \\
\hline
\end{tabular}

Note: ${ }^{*}$ - feedprice $-4 \mathrm{UAH} / \mathrm{kg}$, saponite $-3.5 \mathrm{UAH} / \mathrm{kg}$, aanalcime $-4.0 \mathrm{UAH} / \mathrm{kg}$, bentonite $-3 \mathrm{UAH} / \mathrm{kg},{ }^{* *}-$ fishseedprice $-35 \mathrm{UAH} / \mathrm{kg}, * * *$ - tablefishprice $-50 \mathrm{UAH} / \mathrm{kg}$. 
The obtained conditional profit from cultivation was divided by the area of ponds and the highest profit was obtained in Experiment 2 - $4998 \mathrm{UAH} / \mathrm{ha}$, which was $16.4 \%$ higher than the Control. In Experiment 2 the conditional profit was 4264 $\mathrm{UAH} / \mathrm{ha}$, which was $2 \%$ more than the Control, in Experiment 3 - $4364 \mathrm{UAH} / \mathrm{ha}$, which was $4.2 \%$ more than the control.

The calculations showed that each of the additives added to the diet of carp had an effect on increasing the profitability after their use. However, supplementation withanalcimewas the most effective and promising for carp feeding.

\section{CONCLUSION AND PERSPECTIVES OF FURTHER DEVELOPMENT}

The study showed a positive effect of the supplementation of fish feed with $3 \%$ saponite, $3 \%$ analcime and $2 \%$ bentonite on growing age- $2+$ carp in pond conditions on fish survival rate, fish productivity and economic efficiency.

Hydrochemical parameters during the experiment were satisfactory, but there was some increase in chloride concentration and permanganate oxidation during the growing season.

When supplementing the fish feed forage-1+ carp with bentonite (Experiment 3), the fish survival rate was the highest: $69.1 \%$ versus $64.2 \%$ in the control group. At the same time, the highest fish productivity of ponds was in Experiment 2 when supplementing the feed with analcime that exceeded the values of Experiment 1 and Experiment 3 by 12.7 and $9.9 \%$, respectively. Compared to the Control, fish productivity in this experimental pond was higher by $13.4 \%$, which indicates the advisability of using analcime in carp feeding.

Use ofsaponite, analcime and bentonite in the feeding of age-1+ carp, the profit in creased by $2,16.4$, and $4.2 \%$, respectively, compared to the control group.

Thus, summarizing the results of the experiment, the most promising among the studied additives may be the use of $3 \%$ analcime in a balanced feed in the feeding of age- $1+$ carp during the growing season that allows increasing overall fish productivity of ponds, reducing feed costs and gaining additional profits.

\section{BIBLIOGRAPHY}

1. Грициняк I. I., Третяк О. М., Колос О. М. Історичні аспекти, стан та перспективи розвитку рибогосподарської діяльності на внутрішніх водоймах України // Вісник Сумського національного аграрного університету. 2014. Вип. 2/1 (24). С. 80-109.

2. Алимов С. І., Кононенко Р. В. Інтенсивні технології в аквакультурі: навчальний посібник. Київ : Фітосоціоцентр, 2013. 280 с.

3. Щербина М. А., Гамыгин Е. А. Кормление рыб в пресноводной аквакультуре. Москва : ВНИРО, 2006. 360 с.

4. Славов В. П., Борщенко В. В., Кулик М. Ф. Использование клиноптилолита и комплексной минеральной добавки на основе сапонита в кормлении коров // Вісник аграрної науки. 1995. № 3. С. 89-94.

5. Вплив вулканічних туфів на мінеральний склад курячих яєць / Кулик М. Ф. та ін. // Корми і кормовиробництво 2010. Вип. 66. С. 338-344.

6. Мухрамова А. А. Оценка состояния молоди русского осетра по рыбоводнобиологическим параметрам и биохимическим показателям крови после кормления экспериментальными кормами // Вестник КазНУ. 2012. № 1. С. $103-106$. 
7. Традиційні і нетрадиційні мінерали у тваринництві / Кулик М. Ф. та ін. Київ : Сільгоспосвіта, 1995. 236 с.

8. Андрійчук В. Ф., Гетьман Г. М., Башинська В. В. Вплив згодовування анальциму на якісні показники сперми кнурів // Вісник ДАУ. 2003. № 1. С. 193-199.

9. Dilawar Hussain. Effect of Aflatoxins in Aquaculture: Use of Bentonite Clays as Promising Remedy // Turkish Journal of Fisheries and Aquatic Sciences. 2018. P. 1009-1016. URL : http://www.trjfas.org/ 10.4194/1303-2712-v18_8_10 (дата звернення 11.03.2020).

10. Безкровна Н. I. Використання природних цеолітів для підвищення ефективності годівлі коропа за умов вирощування на теплих скидних водах : автореф. дис. на здобуття наук. ступеня канд. біол. наук : спец. 03.00.10 «Іхтіологія». Київ, 1994. 25 с.

11. Батуревич О. О., Дерень О. В., Качай Г. В. Ефективність введення сапоніту та анальциму до складу раціону дволіток коропа // Рибогосподарська наука України. 2018. № 4. С. 57-67.

12. Батуревич О. О. Ефективність використання мінералів природного походження в раціоні самиць коропа // Вісник ПДАА. 2019. № 3. С. 132-138.

13. Тлупов Т. X. Эффективность применения природного бентонита при выращивании рыбы в условиях загрязнения водной среды различными токсикантами : автореф. дис. на получ. науч. степени канд. биол. наук : спец. ВАК РФ 03.00.16 «Экология». Ставрополь, 1999. 22 с.

14. Желтов Ю. А. Организация кормления разновозрастного карпа в фермерских рыбных хозяйствах. Киев : ИНКОС, 2006. 282 с.

15. Алекин О. А. Основы гидрохимии. Ленинград : Гидрометеоиздат, 1970. 412 с.

16. СОУ 05.01-37-385:2006. Вода рибогосподарських підприємств. Загальні вимоги та норми. Київ : Міністерство аграрної політики України. 2006. 15 с. (Стандарт Мінагрополітики України).

\section{REFERENCES}

1. Hrytsyniak, I. I., Tretiak, O. M., \& Kolos, O. M. (2014). Istorychni aspekty, stan ta perspektyvy rozvytku rybohospodarskoi diialnosti na vnutrishnikh vodoimakh Ukrainy. Visnyk Sumskoho natsionalnoho ahrarnoho universytetu, 2/1 (24), 80-109.

2. Alymov, S. I., \& Kononenko, R. V. (2013). Intensyvni tekhnolohii v akvakulturi: navchalnyi posibnyk. Kyiv: Fitosotsiotsentr.

3. Shherbina, M. A., \& Gamygin, E. A. (2006). Kormlenie ryb v presnovodnoj akvakul'ture. Moskva: VNIRO.

4. Slavov, V. P., Borshhenko, V. V., \& Kulik, M. F. (1995) . Ispol'zovanie klinoptilolita i kompleksnoj mineral'noj dobavki na osnove saponita v kormlenii korov. Visnik agrarnoi nauki, 3, 89-94.

5. Kulyk, M. F., Obertiukh, Yu. V., Chornolata, L. P., Kostetska, Yu. V., Kulyk, Ya. M., \& Kotsiumbas, I. Ya. (2010). Vplyv vulkanichnykh tufiv na mineralnyi sklad kuriachykh yaiets. Kormy i kormovyrobnytstvo, 66, 338-344.

6. Muhramova, A. A. (2012). Ocenka sostojanija molodi rus'kogo osetra po rybovodno-biologicheskim parametram i biohimicheskim pokazateljam krovi posle kormlenija jeksperimental'nymi kormami. Vestnik KazNU,1, 103-106.

7. Kulyk, M. F., Velychko, I. M., \& Zasukha, T. V. (1995). Tradytsiini i netradytsiini mineraly u tvarynnytstvi. Kyiv: Silhosposvita. 
8. Andriichuk, V. F., Hetman, H. M., \& Bashynska, V. V. (2003). Vplyv zghodovuvannia analtsymu na yakisni pokaznyky spermy knuriv. Visnyk $D A U, 1$, 193-199.

9. Dilawar, H. (2018). Effect of Aflatoxins in Aquaculture: Use of Bentonite Clays as Promising Remedy. Turkish Journal of Fisheries and Aquatic Sciences, 1009-1016. trjfas.org. Retrived from: http://www.trjfas.org/ 10.4194/1303-2712-v18_8_10.

10. Bezkrovna, N. I. (1994). Vykorystannia pryrodnykh tseolitiv dlia pidvyshchennia efektyvnosti hodivli koropa za umov vyroshchuvannia na teplykh skydnykh vodakh. Extended abstract of candidate's thesis. Kyiv.

11. Baturevych, O. O., Deren, O. V., \& Kachai, H. V. (2018). Efektyvnist vvedennia saponitu ta analtsymu do skladu ratsionu dvolitok koropa. Rybohospodarska nauka Ukrainy, 4, 57-67.

12. Baturevych, O. O. (2019). Efektyvnist vykorystannia mineraliv pryrodnoho pokhodzhennia v ratsioni samyts koropa. Visnyk PDAA, 3, 132-138.

13. Tlupov, T. H. (1999). Jeffektivnost' primenenija prirodnogo bentonita pri vyrashhivanii ryby $\mathrm{v}$ uslovijah zagrjaznenija vodnoj sredy razlichnymi toksikantami. Extended abstract of candidate's thesis. Stavropol'.

14. Zheltov, Ju. (2006). A. Organizacija kormlenija raznovozrastnogo karpa $v$ fermerskih rybnyh hozjajstvah. Kiev: INKOS.

15. Alekin, O. A. (1970). Osnovy gidrohimii. Leningrad: Gidrometeoizdat.

16. Voda rybohospodarskykh pidpryiemstv. Zahalni vymohy ta normy (2006). SOU 05.01-37-385:2006. Standart Minahropolityky Ukrainy. Kyiv: Ministerstvo ahrarnoi polityky Ukrainy. 


\section{КРИТИКА І БІБЛІОГРАФІЯ}

Ribogospod. nauka Ukr., 2020; 2(52): 97-128

Received 26.04.20

DOI: https://doi.org/10.15407/fsu2020.02.097

Удк 016:639.3/.6

Received in revised form 22.05.20

Accepted 04.06.20

\section{ПОЛІКУЛЬТУРА В РИБНИЦТВІ. ТЕМАТИЧНА БІБЛІОГРАФІЯ}

І. Й. Грициняк, library@if.org.ua, Інститут рибного господарства НАAН, м. Київ

Т. М. Швець, library@if.org.ua, Інститут рибного господарства НАAН, м. Київ

Мета. Формування довідкового переліку україно- та російськомовних публікацій 3 питань утримання і вирощування риб та інших гідробіонтів у полікультурі.

Методика. Під час системного пошуку у процесі підготовки тематичного переліку було застосовано як цілісний, так і вибірковий методи. Бібліографічне ядро складали виключно україно- та російськомовні наукові видання, наявні у фонді наукової бібліотеки Інституту рибного господарства НААН України.

Результати. Сформовано тематичний бібліографічний перелік публікацій загальною кількістю 225 джерел, що охоплюють часовий інтервал з 1958 по 2019 рр., і висвітлюють біологічні, екологічні та технологічні аспекти впровадження сумісного вирощування різних видів риб, а також інших гідробіонтів у практику рибництва. Літературні джерела розміщені у алфавітному порядку за автором чи назвою, описані згідно з ДСТУ 8302:2015 «/нформація та документація. Бібліографічне посилання. Загальні положення та правила складання», із урахуванням поправок (код УКНД 01.140.40), а також відповідно до вимог оформлення списку літератури за міжнародним стандартом APA style.

Практична значимість. Підготовлений список публікачій може бути використаний науковцями, практиками, студентами, до сфери інтересів яких належать питання удосконалення технологій ведення сучасного рибництва на основі його інтенсифікації, а також впливу полікультури на екосистему водойм.

Ключові слова: полікультура, рибництво, коропові, осетрові, рослиноїдні риби, рибопродуктивність.

\section{POLYCULTURE IN FISHERIES. THEMATIC BIBLIOGRAPHY}

Ir. Hrytsynyak, library@if.org.ua, Institute of Fisheries NAAS, Kyiv

T. Shvets, library@if.org.ua, Institute of Fisheries NAAS, Kyiv

Purpose. Forming a thematic bibliographic list of publications on the rearing of fish and other aquatic organisms in polyculture.

Methods. The complete and selective methods were applied in the process of the systematic search. The bibliographic core have been formed with the publications exclusively in Ukrainian and Russian from the fund of scientific library of the Institute of Fisheries NAAS of Ukraine.

Results. There was composed the thematic list of publications with a total quantity of 225 sources covering the time interval from 1958 to 2019, and highlighting the biological, environmental, and technological aspects of the introduction of co-cultivation of various fish species, as well as other aquatic organisms in the practice of fish farming. The literary sources are arranged in alphabetical order by author or title, and described according to DSTU 8302:2015 "Information and

(С) І. Й. Грициняк, Т. М. Швець, 2020 
documentation. Bibliographic reference. General principles and rules of composition", with the amendments (code UKND 01.140.40), as well as in accordance with the requirements of APA style international standard of references.

Practical value. The list may be useful for scientists, practitioners, students, whose area of interests includes issues of improving the technology of modern fish farming based on intensification of pisciculture, as well as the impact of polyculture on the ecosystem of water bodies.

Key words: polyculture, fish farming, cyprinids, sturgeons, herbivorous fish, fish productivity.

\section{ПОЛИКУЛЬТУРА В РЫБОВОДСТВЕ. ТЕМАТИЧЕСКАЯ БИБЛИОГРАФИЯ}

Ир. И. Грициняк, library@if.org.ua, Институт рыбного хозяйства НАAН, г. Киев Т. М. Швец, library@if.org.ua, Институт рыбного хозяйства НАAН, г. Киев

Цель. Формирование справочного перечня украино- и русскоязычных публикаций по вопросам содержания и выращивания рыб и других гидробионтов в поликультуре.

Методика. В ходе системного поиска в прочессе подготовки тематического перечня были применены как целостный, так и выборочный методы. Библиографическое ядро составляли исключительно украино- и русскоязычные научные издания, имеющиеся в фонде научной библиотеки Института рыбного хозяйства НААН Украины.

Результаты. Сформирован тематический библиографический перечень публикаций в количестве 225 источников, охватывающих временной интервал с 1958 по 2019 г2., и освещающих биологчческие, экологические и технологические аспекты внедрения совместного выращивания различных видов рыб, а также других гидробионтов в практику рыбоводства. Литературные источники размещены в алфавитном порядке по автору или названию, описаны согласно ДСТУ 8302:2015 "Информация и документация. Библиографическая ссылка. Общие положения и правила составления», с учетом поправок (код УКНД 01.140.40), а также в соответствии с требованиями к оформлению списка литературы по международному стандарту APA style.

Практическая значимость. Подготовленный список публикаций может быть использован учеными, практиками, студентами, сфера интересов которых включает вопросы усовершенствования технологий современного рыбовоства на основе его интенсификации, а также влияния поликультуры на экосистему водоемов.

Ключевые слова: поликультура, рыбоводство, карповые, осетровые, растительноядные рыбы, рыбопродуктивность.

\section{ЛІТЕРАТУРА}

1. Абиотические и биотические условия выращивания сеголеток судака в прудовой поликультуре рыб / Мамедов Р. А. и др. // Вопросы рыбного хозяйства Беларуси. 2009. Вып. 25. С. 128-136.

2. Азизов Ф. Ф., Раджабов Ф. М. Выращивание поликультуры карповых рыб в условиях Гиссарской долины Таджикистана // Рыбоводство и рыбное хозяйство. 2017. № 7. С. 39-46.

3. Алимов И. А. Опыт выращивания сеголетков вырезуба в поликультуре// Научные основы сельскохозяйственного рыбоводства: состояние и перспективы развития : сборник научных трудов. Москва, 2010. С. 143-146.

4. Алтухов К. А. Эффективность применения поликультуры растительноядных рыб в прудах западных областей УССР // Рыбное хозяйство. 1972. Вып. 14. С. $52-59$. 
5. Алхімов Ю. М., Незнамов С. О., Шерман I. М. Густота посадки і співвідношення компонентів полікультури у ставах на торф'яних і піщаних грунтах при вирощуванні цьоголіток коропових риб // Рибогосподарська наука України. 2013. № 2. С. 66-69.

6. Аль-Хашими Сабах Хамиль Исмаил. Питание и пищевые взаимоотношения сеголетков карпа и растительноядных рыб при совместном выращивании в прудах Киевского Полесья : автореф. дис. на соискание уч. степени канд. биол. наук. Ленинград : ГосНИОРХ, 1974. 19 с.

7. Артамонова Т. И., Киселев А. Ю. Химический состав и калорийность тела рыб, выращенных в поликультуре по технологии, нетрадиционной для 1 зоны рыбоводства // Сборник научных трудов ВНИИПРХ. 2005. Вып. 80. С. 3946.

8. Артамонова Т. И., Овинникова В. В., Федорченко Ф. Г. Особенности питания двух- и трехлеток белого амура и карпа, выращиваемых в условиях нетрадиционной поликультуры // Сборник научных трудов ВНИИПРХ. 2002. Вып. 78. С. 6-11.

9. Ба М. Л., Томеди Э. М., Тихомиров А. М. Опыт выращивания бестера в поликультуре с белым амуром на Чаганском рыбопитомнике // Осетровые на рубеже XXI в. : Междунар. конф. : тезисы докл. Астрахань, 2000. С. 293-294.

10. Бабий А. А. Морфо-биологические особенности гибрида пелядь $\times$ сиг как объекта поликультуры озерного товарного рыбоводства : автореф. дис. на соискание уч. степени канд. биол. наук. Москва : ВНИИПРХ, 1987. 24 с.

11. Байрамов Р. А., Киселев А. Ю. Влияние факторов среды и размерных характеристик пруда на его рыбопродуктивность в условиях поликультуры // Рыбоводство и рыбное хозяйство. 2008. № 2. С. 31-33.

12. Бардачев Ю. Н., Рогальский Ф. Б., Дидык А. А. Методы формирования состава поликультуры товарной рыбы в водоеме // Современные проблемы гидробиологии. Перспективы, пути и методы решений-2 : Междун. научн. конф. : матер. Херсон, 2008. С. 49-51.

13. Бекин А. Г., Вундцеттель М. Ф. Эффективность использования прудовых экосистем при различных типах поликультуры // Проблемы воспроизводства растительноядных рыб, их роль в аквакультуре : конф. : матер. докл. Адлер, 2000. C. $62-64$.

14. Бер С. Б., Магомаев Ф. М., Абдусамадов А. С. Эффективность использования минеральных удобрений при выращивании сеголетков растительноядных рыб в поликультуре с карпом в Дагестанской АССР // Сборник научных трудов ВНИИПРХ. 1981. Вып. 31. С. 59-67.

15. Биологические основы и общая характеристика поликультурного рыбоводства // Руководство по биотехнике разведения и выращивания дальневосточных растительноядных рыб. Москва : ВНИИПРХ, 2000. С. 150155.

16. Блинова Р. Д., Бурлакова А. Н., Зайцева Е. М. Пищевые отношения сеголетков карпа и черного буффало при совместном выращивании в условиях Среднего Поволжья // Сборник научных трудов ГосНИОРХ. 1980. Вып. 158. С. 70-75.

17. Боброва Ю. П. Выращивание белого амура в поликультуре с другими рыбами в прудах Московской обл. // Труды ВНИИПРХ. 1966. Т. 14. С. 3-14. 
18. Богерук А. К., Камехо С., Уливер С. Опыт поликультурного выращивания рыбы в малом водохранилище Республики Куба // Сборник научных трудов ВНИИПРХ. 1981. Вып. 31. С. 254-264.

19. Боровик Е. А. Радужная форель - ценная добавочная рыба к карпу // Труды БелНИИРХ. 1970. Т. 7. С. 266-270.

20. Бортник А. Ф. Поликультура растительноядных рыб в водоемах-охладителях ГРЭС : автореф. дис. на соискание уч. степени канд. биол. наук. Москва : ВНИИПРХ, 1986. 24 с.

21. Булатович М. А. Развитие фитопланктона в нагульных прудах при выращивании рыб в поликультуре // Рыбное хозяйство. 1979. Вып. 29. С. 5458.

22. Васильева Л. М., Сокольский А. Ф., Медная Л. И. Выращивание веслоноса совместно с карпом и растительноядными рыбами в прудовых хозяйствах Астраханской области : методические указания. Астрахань : БИОС, 1997. 32 c.

23. Веригин Б. В., Пушкарь В. Я. Управление продуктивностью экосистемы прудовых водоемов и формы поликультуры // Итоги и перспективы рыбохозяйственного использования растительноядных рыб: 8 Всесоюз. совещ. : тезисы докл. Киев : Наукова думка, 1977. С. 34-35.

24. Виноградов В. К. Пастбищная технология выращивания рыбы // Актуальные аспекты рыборазведения в современных условиях. Санкт-Петербург : КрасНИИРХ ; ГосНИОРХ, 1999. С. 152-154.

25. Виноградов В. К. Поликультура растительноядных рыб в прудовом рыбоводстве и естественных водоемах // Сборник научных трудов ВНИИПРХ. 1975. Вып. 15. С. 3-19.

26. Виноградов В. К., Воропаев Н. В., Данченко А. Д. Материалы к трофологическому анализу поликультуры в прудовом рыбоводстве // Итоги и перспективы рыбохозяйственного использования растительноядных рыб : 8 Всесоюз. совещ. : тезисы докл. Киев : Наукова думка, 1977. С. 35-37.

27. Виноградов В. К., Ерохина Л. В. Оптимизация видового и количественного состава поликультуры как метод повышения эффективности товарного рыбоводства // Ресурсосберегающие технологии в аквакультуре : симпоз. : матер. докл. Адлер, 1999. С. 25.

28. Владовская С. А., Гамаюн Е. П. Использование щуки в условиях интенсивного рыбоводства (в т. ч. зарубежный опыт) // Рыбное хозяйство : обзорная информация. Москва, 1980. Вып. 2. 32 с. (Серия : Рыбохозяйственное использование внутренних водоемов).

29. Власов В. А. Поликультура в прудовом рыбоводстве // Рыбоводство : учеб. пособие. 2-е изд., стер. Санкт-Петербург : Лань, 2012. С. 152-157.

30. Власов В. А., Лесин К. М. Использование поликультуры в прудовом рыбоводном хозяйстве 2 зоны рыбоводства // Рыбное хозяйство : информационный пакет. Москва, 1997. Вып. 1. С. 58-60. (Серия : Аквакультура).

31. Влияние азотно-фосфорных и калийных удобрений на продуктивность прудов при поликультуре рыб / Харитонова Н. Н. и др. // Рыбное хозяйство. 1988. Вып. 42. С. 15-20.

32. Войнарович А., Мот-Поульсен Т., Петери А. Поликультура карповых рыб в странах Центральной и Восточной Европы, Кавказа и Центральной Азии. 
Руководство. Рим : ФАО, 2014. 88 стр. (Технический документ ФАО по рыболовству и аквакультуре ; № 554).

33. Воронин В. М. Размерная структура стада растительноядных рыб в прудовой поликультуре : автореф. дис. на соискание уч. степени канд. биол. наук. Москва : ВНИИПРХ, 1985. $23 \mathrm{c.}$

34. Воронин В. М., Толчинский Г. И. Размерная структура стада сеголетков растительноядных рыб в прудовой поликультуре // Сборник научных трудов ВНИИПРХ. 1983. Вып. 38. С. 41-51.

35. Воронова Г. П., Куцко Л. А., Пантелей С. Н. Выращивание товарной рыбы на естественных кормах в условиях нетрадиционной поликультуры во второй рыбоводной зоне Беларуси // Рыбоводство и рыбное хозяйство. 2013. № 9. С. $28-33$.

36. Воронова Г. П., Куцко Л. А., Пантелей С. Н. О технологических приемах выращивания белого амура в поликультуре рыб с использованием зеленых кормов наземной растительности // Вопросы рыбного хозяйства Беларуси. 2011. Вып. 27. С. 50-58.

37. Выращивание гибридных форм карасекарпа в поликультуре с карпом в первой зоне рыбоводства / Артамонова Т. И. и др. // Сборник научных трудов ВНИИПРХ. 2010. Вып. 85. С. 18-33.

38. Выращивания двухлеток белого амура в поликультуре в 1 зоне рыбоводства / Федорченко В. И. и др. // Сборник научных трудов ВНИИПРХ. 2002. Вып. 78. C. $15-20$.

39. Выращивание молоди осетра в поликультуре с белым амуром / Горбачева Л. Т. и др. // Проблемы воспроизводства растительноядных рыб, их роль в аквакультуре : конф. : матер. докл. Адлер, 2000. С. 68-70.

40. Выращивание сеголеток белого амура в поликультуре при направленном формировании кормовой базы выростных прудов / Шмакова 3. И. и др. // Сборник научных трудов ВНИИПРХ. 2002. Вып. 78. С. 20-29.

41. Выращивание товарной прудовой рыбы в поликультуре с использованием ресурсосберегающей технологии / Кончиц В. В. и др. // Проблемы воспроизводства растительноядных рыб, их роль в аквакультуре : конф. : матер. докл. Адлер, 2000. С. 81-83.

42. Выращивание товарной рыбы в поликультуре / Мищенко Н. В. и др. // Рыбное хозяйство. 1984. № 6. С. 45- 46.

43. Галковская Г. А., Соболев Ю. А. Особенности формирования сообщества зоопланктона при поликультуре карпа с растительноядными рыбами // Труды БелНИИРХ. 1972. Т. 8. С. $73-81$.

44. Гиряев А. С. Физиолого-биохимическая характеристика молоди карповых рыб, выращиваемых в поликультуре в условиях 2-4 зон рыбоводства : автореферат дисс. на соискание уч. степени канд. биол. наук. Москва : ВНИИПРХ, 1990. 19 с.

45. Гринжевський М. В., Пшеничний Д. Р. Вирощування дволіток короповосазанових гібридів у полікультурі // Рибогосподарська наука України. 2007. № 1. С. $41-45$.

46. Гринжевський М. В., Янінович Й. С., Швець Т. М. Полікультура 3 шістьох видів риб // Рибогосподарська наука України. 2009. № 1. С. 38-42.

47. Гринжевський М. В., Янінович Й. Є., Швець Т. М. Ефективність ставової полікультури // Рибогосподарська наука України. 2008. № 2. С. 41-44. 
48. Гробокопатель М. Г., Балан О. І. Рослиноїдні риби і короп - вигідні сусіди // Тваринництво України. 1973. № 12. С. 44-45.

49. Гробокопатель М. Г., Прокопенко А. А. Эффективность выращивания трехлетков пестрого толстолобика в поликультуре в опытном хозяйстве «Нивка» // Рыбное хозяйство. 1975. Вып. 21. С. 111-113.

50. Гузюр Я., Возняк М. Выращивание речного язя (Leuciscus idus L.) в прудовой поликультуре в северной зоне Польши (Ольштынская область) // Современное состояние и перспективы развития аквакультуры. Горки, 1999. C. $102-104$.

51. Данченко А. Д. Особенности поведения и ската сеголетков растительноядных рыб и карпа при выращивании в поликультуре // Труды ВНИИПРХ. 1976. Т. 25. С. $41-49$.

52. Данченко А. Д. Питание и пищевые взаимоотношения сеголетков растительноядных рыб и карпа при выращивании в поликультуре // Труды ВНИИПРХ. 1976. Т. 25. С. 50-58.

53. Данченко А. Д. Поликультура растительноядных рыб как метод интенсификации прудового рыбоводства (на примере рыбхозов Краснодарского края и Куйбышевской области) : автореф. дис. на соискание уч. степени канд. биол. наук. Калининград, 1974. 34 с.

54. Данченко А. Д. Поликультура растительноядных рыб как метод интенсификации прудового рыбоводства (на примере рыбхозов Краснодарского края и Куйбышевской области) : автореф. дис. на соискание уч. степени канд. биол. наук. Калининград : Калининградский технический институт рыбной промышленности и хозяйства, 1974. 34 с.

55. Дао Суан Лок, Носаль А. Д. Выращивание посадочного материала растительноядных рыб в поликультуре с карпом в прудах Украинского Полесья // Технология производства рыбы. Москва, 1974. С. 123-129.

56. Демьяненко В. Ф. Технология комбинированного выращивания рыбы с использованием теплых вод в зоне умеренного климата // Актуальные аспекты рыборазведения в современных условиях. Санкт-Петербург : КрасНИИРХ ; ГосНИОРХ, 1999. С. 124-151.

57. Джана В. В., Рой С. К. Рост рыб в рыбоводных прудах с поликультурой в зависимости от численности бактерий, участвующих в круговороте азота // Гидробиологический журнал. 1983. № 2. С. 106-108.

58. Дулон Р., Завьялов А. П. Численность и видовой состав фито- и зоопланктона при выращивании карповых рыб в поликультуре в условиях неспускных водоемов республики Бангладеш // Рыбоводство и рыбное хозяйство. 2018. № 2. С. $24-32$.

59. Еловенко В. Н. Хищники в прудовой поликультуре // Рыбоводство и рыбное хозяйство. 2006. № 2. С. 39.

60. Емтыль М. Х. Буффало как объект прудовой поликультуры (на примере рыбхозов Краснодарского края) : автореф. дис. на соискание уч. степени канд. биол. наук. Москва : ВНИИПРХ, 1987. 24 с.

61. Жигин А. В. Опыт выращивания сибирского осетра в поликультуре с тиляпией // Создание и эксплуатация ремонтно-маточных стад осетровых рыб с использованием теплых вод различного происхождения : науч.-практ. конф., 22-23 дек. 2003 г. : матер. Санкт-Петербург : ГосНИОРХ, 2003. С. 22-26.

62. Жигин А. В., Терентьев В. П. Поликультура рыб в водоеме // Рыбоводнорыболовное рекреационное хозяйство. Москва : ВНИРО, 2015. 
63. Жигин А. В., Терентьев В. П. Функциональная значимость видов в поликультуре водоема // Рыбоводно-рыболовное рекреационное хозяйство. Москва : ВНИРО, 2015.

64. Жуков П. И. Расчет оптимальной плотности посадки рыб при выращивании в поликультуре // Вопросы рыбного хозяйства Беларуси, 2000. Вып. 16. С. 1316.

65. 3 досвіду вирощування товарного веслоноса в ставовій полікультурі лісостепової зони / Ганкевич Б. О. и др. // Рибогосподарська наука України. 2009. № 4. С. $70-76$.

66. Изменение состава прудовой поликультуры на юге России / Речинский В. В. и др. // Актуальні проблеми аквакультури та раціонального використання водних біоресурсів : Міжнар. конф., м. Київ, 26-30 вер. 2005 р. : матер. Київ : ІРГ УААН, 2005. С. 220-222.

67. Изучение оптимальной поликультуры молоди при высокой степени интенсификации выростных прудов / Кожокару Т. Т. и др. // Совершенствование технологии выращивания рыб при высокой степени интенсификации. Кишинев, 1982. С. 11-12.

68. Изучение роста американского веслоноса (Polyodon spathula) на первом году выращивания в поликультуре / Кармен Н. и др. // Вопросы рыбного хозяйства Беларуси. 2008. Вып. 24. С. 233-236.

69. Ирихимович А. И., Тютюник С. Н. Материалы к нагулу рыб дальневосточного комплекса совместно с карпами в прудах Молдавии // Сборник научно-исследовательских трудов ВНИИПРХ. 1970. № 4. С. 102111.

70. Каплич В. М., Звягинцев В. Б., Герасимчик В. А. Поликультура и добавочные виды рыб // Основы рыбоводства и рыболовства : учеб. пособие. Минск : БГТУ, 2012. С. 85.

71. Киселева Л. А. Влияние кормовой базы в прудах на выращивание растительноядных рыб в поликультуре с карпом // Сборник научных трудов ВНИИПРХ.1990. Вып. 59. С. 67-68.

72. Коваленко В. О. До питання про місце коропа в ставковій полікультурі товарного рибництва // Рибне господарство України. 2003. № 6. С. 18-20.

73. Кожин Н. И. Выращивание молоди в монокультуре и поликультуре // Справочник рыбовода по искусственному разведению промысловых рыб. Москва : Пищевая промышленность, 1971. С. 144-146.

74. Кожокару Е. В., Михайловский Н. М., Яловицкая Н. И. Влияние минеральных удобрений на фитопланктон прудов при совместном выращивании сеголеток толстолобиков и карпа // Итоги и перспективы рыбохозяйственного использования растительноядных рыб : 8 Всесоюз. совещ. : тезисы докл. Киев : Наукова думка, 1977. С. $71-73$.

75. Кожокару Т. Т. Влияние частоты внесения удобрений на рыбопродуктивность прудов при поликультуре рыб // Итоги и перспективы рыбохозяйственного использования растительноядных рыб : 8 Всесоюз. совещ. : тезисы докл. Киев : Наукова думка, 1977. С. 70-71.

76. Козлов В. И. Биотехника выращивания сеголетков растительноядных рыб в поликультуре с карпом // Аквакультура. Москва : МГУТУ, 2004. С. 121-123.

77. Козлов В. И. Новые формы поликультуры // Аквакультура. Москва : МГУТУ, 2004. С. $128-131$. 
78. Козлов В. И. Рекомендации по технологии производства рыбы без применения комбикормов с выходом 6-8 ц/га в рыбоводных хозяйствах Нечерноземной зоны России // Актуальные аспекты рыборазведения в современных условиях. Санкт-Петербург : КрасНИИРХ ; ГосНИОРХ, 1999. С. $86-89$.

79. Кончиц В. В. Выращивание товарных растительноядных рыб в поликультуре с карпом // Растительноядные рыбы как основа интенсификации рыбоводства Беларуси. Минск : Хата, 1999. С. 198-224.

80. Кончиц В. В. О возможном направлении расширения внедрения растительноядных рыб в поликультуру рыборазведения Беларуси // Проблемы воспроизводства растительноядных рыб, их роль в аквакультуре : конф. : матер. докл. Адлер, 2000. С. 26-27.

81. Кончиц В. В. Повышение продуктивности прудов за счет поликультуры основных и добавочных видов рыб // Аквакультура в Беларуси. Минск : Белорусская наука, 2005. С. 58-70.

82. Кончиц В. В. Эффективность применения поликультуры и внедрения новых объектов рыбоводства // Вопросы рыбного хозяйства Беларуси. 2008. Вып. 24. C. $105-109$.

83. Кормовая база и питание сеголетков черного амура при выращивании в поликультуре / Жемаева Н. П. и др. // Проблемы аквакультуры и функционирования водных экосистем : Междунар. науч.практ. конф. молодых ученых, 25-28 февр. 2002 г. : матер. Киев, 2002. С. 22-23.

84. Королев А. Е. Энергетический баланс и рационы молоди судака и пеляди при их совместном выращивании в пруду // Сборник научных трудов ГосНИОРХ. 1984. Вып. 22. С. 21-30.

85. Королев А. П., Ходячий Н. П. Поликультурное рыбоводство - рентабельная отрасль. Москва : Легкая и пищевая промышленность, 1981. 104 с.

86. Королькова М. С., Овинникова В. В., Воронков Л. А. Состав поликультуры при производстве товарного карпа массой более 600 г при двухлетнем выращивании // Сборник научных трудов ВНИИПРХ. 1991. Вып. 61. С. 95103.

87. Костылев В. А., Барсов И. Г., Шнитов Б. И. Особенности подращивания молоди и выращивания посадочного материала карпа и растительноядных рыб в тепловодном хозяйстве // Сборник научных трудов ВНИИПРХ. 1981. Вып. 30. С. $52-62$.

88. Косырева Р. Я. Питание молоди судака при выращивании ее в нерестововыростных хозяйствах совместно с другими видами рыб : автореф. дис. на соискание уч. степени канд. биол. наук. Москва, 1958. 14 с.

89. Кражан С. А., Сисоєва О. М. Живлення цьоголіток коропа при вирощуванні в полікультурі у ставах Лісостепової зони України // Рибне господарство. 1999. Вип. 49-50. С. 153-157.

90. Кражан С. А., Хижняк М. І., Горобець Л. В. Розвиток природної кормової бази ставів лісостепової зони України при вирощуванні цьоголіток коропа та рослиноїдних риб у полікультурі // Рибне господарство. 2000. Вип. 58. С. 6672.

91. Кубарский И. Ф. Опыт выращивания толстолобиков совместно с карпом в прудах рыбхоза «Жовтнево» // Рыбное хозяйство. 1972. Вып. 15. С. 37-39. 
92. Кузьмин И. А. Повышение продуктивности выростных прудов путем направленного воздействия на экосистему // Аквакультура и интегрированные технологии: проблемы и возможности : конф. : матер. Москва, 2005. Т. 2. С. 147-153.

93. Кулеш В. Ф., Алехнович А. В. Выращивание молоди длиннопалого рака (Astacus leptodactylus) в садках и прудах в поликультуре с рыбой на подогретых сбросных водах теплоэлектростанции // Гидробиологический журнал. 2010. № 1. С. 47-61.

94. Куріненко Г. А., Мрук А. І., Колос О. М. Вирощування пеляді (Coregonus peled Gmelin) в полікультурі 3 короповими (Cyprinidae) та осетровими (Acipenseridae) рибами // Рибогосподарська наука України. 2016. № 1. С. 4356.

95. Куцко Л. А., Пантелей С. Н. Формирование гидрохимического режима прудов при пастбищном выращивании товарной рыбы в поликультуре // Вопросы рыбного хозяйства Беларуси. 2006. Вып. 22. С. 174-183.

96. Кучеренко Н. С. О влиянии пестрого и белого толстолобиков на рост карпа при совместном выращивании // Сборник научных трудов ВНИИПРХ. 1972. Вып. 2. С. $50-59$.

97. Лебедева И. Что дала поликультура // Рыбоводство и рыболовство. 1970. № 2. С. 20.

98. Литвиненко А. И. Инструкция по интенсивному подращиванию молоди карпа и растительноядных рыб в прудах с геотермальным водоснабжением // Актуальные аспекты рыборазведения в современных условиях. СанктПетербург : КрасНИИРХ ; ГосНИОРХ, 1999. С. 30-34.

99. Лошкова Ю. М. Технолого-біологічні аспекти вирощування дволіток коропових риб у полікультурі для зарибнення водойм пониззя Дніпра : автореф. дис. на здобуття наук. ступеня канд. с.-г. наук. Київ : Інститут рибного господарства НААН, 2016. 20 с.

100. Лупачева Л. И. Пищевые отношения личинок белого толстолобика и белого амура при совместном выращивании // Рыбное хозяйство. 1970. Вып. 11. С. $34-37$.

101. Магомаев Ф. М. Внедрение поликультуры растительноядных рыб во внутренние водоемы Дагестана // Итоги и перспективы рыбохозяйственного использования растительноядных рыб : 8 Всесоюз. совещ. : тезисы докл. Киев : Наукова думка, 1977. С. 86-87.

102. Магомаев Ф. М., Бер С. Б., Щащаев Ю. А. Выращивание рыбопосадочного материала растительноядных рыб в поликультуре с карпом в Дагестане // Сборник научных трудов ВНИИПРХ. 1979. Вып. 26. С. 158-167.

103. Мамедов Р. А., Минаев О. В. Опыт выращивания сеголетков судака в поликультуре // Вопросы рыбного хозяйства Беларуси. 2008. Вып. 24. С. 134-138.

104. Мамонтов Ю. П., Алымов С. И., Захаров В. С. Расчеты норм посадки рыбы в выростные и нагульные пруды при моно- и поликультуре // Методы повышения эффективности прудового рыбоводства. Москва : Росинформагротех, 2012.

105. Мамонтова Р. П. Зообентос нагульных прудов с поликультурой рыб // Инновационные технологии аквакультуры : Междунар. науч. конф., 21-22 сент. 2009 г. : тезисы докл. Ростов-на-Дону : ЮНЦ РАН, 2009. С. 89-92. 
106. Мамонтова Р. П., Артамонова Т. И., Трубникова М. К. Естественная кормовая база прудов и особенности пищевых взаимоотношений гибрида карасекарпа при выращивании в поликультуре с карпом // Сборник научных трудов ВНИИПРХ. 2011. Вып. 86. С. 10-19.

107. Маслова Н. И. Биологическая характеристика линя - объекта аквакультуры (поликультура) // Прибрежное рыболовство и аквакультура : обзор. информ. 2006. Вып. 1. С. $1-41$.

108. Маслова Н. И., Серветник Г. Е. Рыбоводно-биологическая оценка видов рыб, пригодных для выращивания в поликультуре (язь, линь, щука) : монография. Москва : РГАУ-МСХА, 2016. 197 с.

109. Маслова Н. И., Серветник Г. Е., Петрушин А. Б. Эколого-биологические основы поликультурного рыбоводства. Москва, 2002. 268 с.

110. Маслова Н. И., Серветник Г. Е., Петрушин А. Б. Эколого-ландшафтные особенности водоемов и поликультура рыб // Рыбохозяйственное использование водоемов комплексного назначения : сборник. Москва, 2001. Ч. 2. С. $155-173$.

111. Медведєв М. Г., Кравчук Н. М., Третяк О. М. Застосування оптимізаційного моделювання при визначенні щільностей посадки об'єктів полікультури за випасного вирощування риби в ставах // Рибне господарство. 1999. Вип. 5455. С. $140-145$.

112. Мельченков Е. А., Архангельский В. В., Минияров Ф. Т. Веслонос как объект товарного выращивания в поликультуре // Сборник научных трудов ВНИИПРХ. 2002. Вып. 78. С. 66-69.

113. Мельченков Е. А., Чертихин В. Г. Разводите веслоноса // Рыбоводство и рыболовство. 2000. № 1. С. 20.

114. Методические указания по формированию естественной кормовой базы для амура в поликультуре выростных прудов VII зоны рыбоводства. Москва, 1987. $13 \mathrm{c}$.

115. Милановский Ю. Е. Использование рыб-фитофагов в прудовой поликультуре // Зоология позвоночных. Москва, 1974. Т. 5. С. 95-135.

116. Милановский Ю. Е., Пушкарь В. Я. Характеристика условий питания толстолобика как основа технологического контроля поликультуры рыб // Итоги и перспективы рыбохозяйственного использования растительноядных рыб : 8 Всесоюз. совещ. : тезисы докл. Киев : Наукова думка, 1977. С. 91—93.

117. Минияров Ф. Т., Маньшина А. А. Разработка бионормативов рентабельного выращивания осетровых рыб в поликультуре с растительноядными рыбами // Осетровые на рубеже XXI в. : Междунар. конф. : тезисы докл. Астрахань, 2000. C. 308-309.

118. Минияров Ф. Т., Щербатова Т. Г., Китанов А. А. Поликультура при товарном выращивании в осетровых прудах // Аквакультура осетровых рыб: достижения и перспективы развития : Вторая Междунар. науч.-практ. конф., 21-22 нояб. 2001 г. : матер. Астрахань : БИОС ; Нова, 2001. С. 104-106.

119. Михайловский Н. М., Кожокару Е. В., Каленик Т. И. Выращивание сеголеток в поликультуре с преобладанием толстолобиков в Приднестровском рыбхозе // Совершенствование технологии выращивания рыб при высокой степени интенсификации. Кишинев, 1982. С. 48-55.

120. Міжвидова трофічна конкуренція риб, яких вирощують у полікультурі / Янінович Й. Є. та ін. // Рибогосподарська наука України. 2011. № 1. С. $33-$ 38. 
121. Морузи И. В. Эффективность выращивания пеляди и байкальского омуля (в поликультуре с карпом) в карповых рыбоводных прудах Алтайского края // Холодноводная аквакультура: старт в 21 век : Междунар. симп. : матер. Москва, 2003. С. 131-132.

122. Морузи И. В., Пищенко Е. В. Эффективность выращивания пеляди в карповых рыбоводных прудах юга Западной Сибири // Рыбоводство и рыбное хозяйство. 2007. № 3. С. $19-21$.

123. Мухаммед Нагиб Бакир. Интенсивная товарная прудовая поликультура в дельте Нила : дис ... кандидата с.-х. наук. Астрахань : Астраханский технический институт рыбной промышленности и хозяйства, 1993. 142 с.

124. Мухачев И. С. Рекомендации по технологии производства товарной рыбы без применения комбикормов с выходом 6-6,5 ц/га в рыбоводных хозяйствах юга Зауралья и Западной Сибири // Актуальные аспекты рыборазведения в современных условиях. Санкт-Петербург : КрасНИИРХ ; ГосНИОРХ, 1999. C. $91-95$.

125. Мухачев И. С. Рыбохозяйственная мелиорация озер в процессе выращивания товарной пастбищной поликультуры // Рыбоводство и рыбное хозяйство. 2018. № 12(155). С. 45-53.

126. Мухачев И. С., Гунин А. П. Пастбищная поликультура на водоемах Урала и Западной Сибири // Современное состояние и перспективы развития аквакультуры. Горки, 1999. С. 111-112.

127. Неборачек С. И. Садковое выращивание двухлетков канального сома в поликультуре с толстолобиками // Рыбное хозяйство. 1984. Вып. 38. С. 5257.

128. Некрасова С. О. Мониторинг и управление гидрохимической ситуацией с помощью поликультуры // Сельскохозяйственное рыбоводство: возможности развития и научное обеспечение инновационных технологий : Междунар. науч.-практ. конф., 5-7 сент. 2012 г. : докл. Москва : РГАУ-МСХА, 2012. С. $226-232$.

129. Никонова Р. С. Биологические основы товарной поликультуры рыб в дельте Волги : автореф. дис. на соискание уч. степени канд с.-х. наук. Москва, 1983. $16 \mathrm{c}$.

130.Никонова Р. С. К оценке эффективности использования комбикормов при выращивании карпа в поликультуре с растительноядными рыбами // Итоги и перспективы рыбохозяйственного использования растительноядных рыб : 8 Всесоюз. совещ. : тезисы докл. Киев : Наукова думка, 1977. С. 100-101.

131. Никонова Р. С. Некоторые данные по питанию и росту двухлеток буффало при совместном выращивании с растительноядными рыбами и карпом // Итоги и перспективы рыбохозяйственного использования растительноядных рыб : 8 Всесоюз. совещ. : тезисы докл. Киев : Наукова думка, 1977. С. 101— 103.

132.Никонова Р. С. Рекомендации по технологии производства рыбы без применения комбикормов с выходом 8-12 ц/га в рыбоводных хозяйствах Нижневолжского района // Актуальные аспекты рыборазведения в современных условиях. Санкт-Петербург : КрасНИИРХ ; ГосНИОРХ, 1999. С. $89-91$.

133. Новоженин Н. П. Радужная форель как объект поликультуры в прудовом рыбоводстве // Рыбохозяйственное использование водоемов комплексного назначения : сборник. Москва, 2001. Ч. 2. С. 173-179. 
134. Носаль А. Д., Суан Лок Дао. Выращивание сеголеток белого толстолобика совместно с белым амуром и карпом в прудах хозяйства «Нивка»// Рыбное хозяйство. 1972. Вып. 15. С. 32-34.

135. Опыт выращивания по органической технологии молоди растительноядных рыб в поликультуре с бестером / Киреева И. Ю. и др. // Рыбоводство и рыбное хозяйство. 2008. № 4. С. 16-18.

136. Особенности выращивания бестера в прудах в поликультуре с растительноядными рыбами / Васильева Л. М. и др. // Вопросы рыбного хозяйства Беларуси. 2018. Вып. 34. С. 156-166.

137. Пантелей С. Н. Закономерности формирования рыбопродуктивности прудов при пастбищном выращивании карповых рыб в поликультуре // Вопросы рыбного хозяйства Беларуси. 2005. Вып. 21. С. 136-140.

138. Пантелей С. Н. Зообентос нагульных прудов при пастбищном выращивании товарной рыбы в поликультуре // Аквакультура и интегрированные технологии: проблемы и возможности : конф. : матер. Москва, 2005. Т. 2. С. $97-100$.

139. Пантелей С. Н. Эффективность различных видов поликультур при пастбищном выращивании товарной рыбы // Вопросы рыбного хозяйства Беларуси. 2007. Вып. 23. С. 324-332.

140. Пантелей С. Н., Воронова Г. П. Возможности усовершенствования приёмов ведения прудового рыбоводства путем оптимизации поликультуры рыб и их кормления // Вопросы рыбного хозяйства Беларуси. 2016. Вып. 32. С. 96109.

141. Пархоменко А. М. Повышение эффективности выращивания сеголетков карпа в поликультуре с растительноядными рыбами в условиях рыбоводных хозяйств дельты Волги. Москва, 1985. 16 с.

142. Пелядь - добавочная рыба в прудовом карповом хозяйстве / Головков Г. и др. // Рыбоводство и рыболовство. 1972. № 1. С. 8-9.

143. Перспективы товарной поликультуры в Египте // Рыбное хозяйство : информ. пакет. Москва, 1994. Вып. 4. С. 22-24. (Серия : Аквакультура. Прудовое и озерное рыбоводство).

144. Пиленгас в прудовой поликультуре / Поляруш В. П. и др. // Рыбное хозяйство. 2004. № 5. С. $60-62,78$.

145. Пилипенко Ю. В., Шерман И. М., Шевченко В. Ю. Перспективы формирования искусственных ихтиоценозов континентальных водоемов юга Украины с использованием новых объектов аквакультуры // Современное состояние и перспективы развития аквакультуры. Горки, 1999. С. 28-30.

146. Плиева Т. Х. Выращивание карасевых гибридов в моно- и поликультуре // Рыбоводство и рыбное хозяйство. 2007. № 6. С. 38-43.

147. Полікультура — шлях до інтенсифікації ставового рибництва / Янінович Й. Є. та ін. // Рибогосподарська наука України. 2010. № 4. С. 78-83.

148. Пономарева Е. Н., Ба Мохамед Ламин, Сорокина М. Н. Использование прудов малых площадей для поликультуры осетровых и растительноядных рыб

// Состояние и перспективы развития фермерского рыбоводства аридной зоны. Москва, 2007. С. 131-142.

149. Последовательность и сроки посадки объектов поликультуры в выростные пруды / Ефимова Е. Н. и др. // Сборник научных трудов ВНИИПРХ. 1988. Вып. 53. С. 103-110. 
150. Привезенцев Ю. А., Власов В. А. Поликультура / Рыбоводство. Москва : Мир, 2004. С. 190-200.

151.Применение разновозрастной поликультуры рыб в условиях умеренного климата / Ефимова Е. Н. и др. // Сборник научных трудов ВНИИПРХ. 1987. Вып. 51. С. 153-161.

152. Приходько В. А., Тарасова О. М., Шерман И. М. Рост и пищевые взаимоотношения сеголеток белого амура с карпом при совместном выращивании // Рыбное хозяйство. 1971. Вып. 13. С. 54-60.

153. Приходько В. А., Шерман И. М. Экология выращивания сеголеток белого амура в монокультуре и совместно с карпом // Рыбное хозяйство. 1969. Вып. 9. С. $24-29$.

154. Продукционные свойства белого толстолобика как объекта поликультуры средней полосы СССР / Ефимова Е. Н. и др. // Сборник научных трудов ВНИИПРХ.1985. Вып. 45. С. 26-32.

155. Пушкарь В., Дубровин В. Поликультура рыб на индустриальной основе // Рыбоводство и рыболовство. 1986. № 1. С. 8-9.

156. Пшеничний Д. Р. Ефективність вирощування товарних дволіток короповосазанових гібридів в полікультурі 3 трилітками рослиноїдних риб за інтенсивною технологією : автореф. дис. на здобуття наук. ступеня канд. с.-г. наук. Київ: Інститут рибного господарства Української академії аграрних наук, 2009. 20 с.

157. Развитие фитопланктона в прудах Беларуси при выращивании в них веслоноса / Кончиц В. В. и др. // Вопросы рыбного хозяйства Беларуси. 2006. Вып. 22. С. $108-120$.

158. Результаты опытов по выращиванию рыбопосадочного материала традиционных и перспективных объектов рыбоводства по интенсивной технологии / Кончиц В. В. и др. // Вопросы рыбного хозяйства Беларуси. 1995. Вып. 13. С. 77-90.

159. Ресурсосберегающая технология совместного выращивания осетровых и растительноядных рыб в садках / Карачев Р. А. и др. // Рациональное использование пресноводных экосистем - перспективное направление реализации национального проекта «Развитие АПК» : конф. : матер. Москва, 2007. С. $166-168$.

160. Руденко Г. П., Эрик В. В. Результаты выращивания молоди ценных видов рыб в поликультуре // Известия ГосНИОРХ. 1975. Т. 99. С. 206-213.

161. Рыбоводно-биологические особенности выращивания растительноядных рыб в поликультуре с бестером / Киреева И. Ю. и др. // Рыбоводство и рыбное хозяйство. 2008. № 2. С. $22-27$.

162. Рыбопродуктивность нагульных прудов при выращивании поликультуры растительноядных рыб с карпом и карпокарасем по нетрадиционной технологии в 1 зоне рыбоводства / Артамонова Т. И. и др. // Сборник научных трудов ВНИИПРХ. 2006. Вып. 81. С. 3-18.

163. Савушкина С. И., Алимов И. А. Физиолого-биохимическая характеристика рыб, выращенных в условиях поликультуры и по усовершенствованной системе кормления // Рыбоводство и рыбное хозяйство. 2008. № 6. С. 47-52.

164. Савушкина С. И., Петрушин А. Б., Алимов И. А. Морфо-физиологическая характеристика молоди обыкновенного сома (Silurus glanis L.) в условиях ВКН // Аквакультура и интегрированные технологии: проблемы и возможности : конф. : матер. Москва, 2005. Т. 2. С. 105-109. 
165. Сазанов В. Б. Обоснование технологических элементов выращивания черного амура в поликультуре прудового рыбоводства Беларуси : автореф. дис. на соискание уч. степени канд. с.-х. наук. Жодино, 2008. 20 с.

166. Салазкин А. А. Кормовая база прудов и ее использование молодью сиговых в условиях поликультуры // Известия ГосНИОРХ. 1982. Вып. 181. С. 44-53.

167. Сарсембаев Ж. Г., Кан О. М. Особенности выращивания племенного материала карпа, толстолобика и новых объектов рыбоводства в поликультуре // Сборник научных трудов ВНИИПРХ. 1986. Вып. 48. С. 159165.

168. Серветник Г. Е. Этология и ее роль в прудовом рыбоводстве при формировании поликультуры // Рыбоводство и рыбное хозяйство. 2019. № 1(156). С. $37-45$.

169. Сильникова Г. В. Питание и пищевые взаимоотношения рыб в прудовой поликультуре // Известия ГосНИОРХ. 1981. Вып. 168. С. 131-144.

170. Сильникова Г. В. Поликультура растительноядных рыб при выращивании посадочного материала на рыбопитомнике Николаевской РМС // Известия Государственного научно-исследовательского института озерного и речного рыбного хозяйства. 1983. Вып. 208. С. 57-65.

171. Соболев Ю. А. Выращивание рыбопосадочного материала при поликультуре // Труды БелНИИРХ. 1973. Т. 9. С. 37-45.

172. Соболев Ю. А. Повышение рыбопродуктивности прудов при выращивании растительноядных рыб с карпом // Труды БелНИИРХ. 1972. Т. 8. С. 82-88.

173. Совершенствование технологии выращивания рыбопосадочного материала в поликультуре с растительноядными рыбами в прудах биологической очистки / Субботина Ю. М. и др. // Ресурсосберегающие технологии в аквакультуре : симпоз. : матер. докл. Адлер, 1999. С. 102-103.

174. Совместное выращивание африканского сома Clarias gariepinus (Burchell, 1822) и овощных сельскохозяйственных культур в установках замкнутого водоснабжения (УЗВ) / Кузов А. А. и др. // Континентальная аквакультура: ответ вызовам времени : Всерос. науч.-практ. конф., Москва, ВВЦ, 21-22 янв. 2016 г. : матер. Т. 1. Москва : ВНИИР, 2016. С. 202-206.

175. Сокольский А. Ф., Молодцов А. Н. Осетровые как добавочный объект поликультуры // Ресурсосберегающие технологии в аквакультуре : симпоз. : матер. докл. Адлер, 1999. С. 100-101.

176. Способ выращивания в поликультуре молоди карпа и растительноядных рыб / Багров А. М. и др. // Технологии прудового рыбоводства. Москва : ВНИРО, 2014. С. $152-154$.

177. Столович В. Н., Годлевская Н. Н., Астренков А. В. Выращивание сеголетков растительноядных рыб в рыбхозах Беларуси // Вопросы рыбного хозяйства Беларуси, 2006. Вып. 22. С. 205-207.

178. Субботина Ю. М., Смирнова И. Р. Перспективные объекты для разведения в рыбоводно-биологических прудах // Современное состояние и перспективы развития аквакультуры. Горки, 1999. С. 26-28.

179. Суховерхов Ф. М. Биологические основы и эффективность поликультуры в прудовом рыбоводстве. Москва : Пищевая промышленность, 1966. 84 с.

180. Суховерхов Ф. М. Выращивание белого амура, толстолобика и белого леща в прудах Российской Федерации // Совещание по акклиматизации амурских рыб в водоемах европейской части СССР : тезисы докл. Киев : Институт гидробиологии, 1958. С. 6-9. 
181. Сыров В. С., Шерман И. М. К вопросу о совместном выращивании сеголеток карпа и белого амура в экспериментальных условиях // Рыбное хозяйство. 1972. Вып. 14. С. 65-69.

182. Тагирова Н. А., Кузьмин И. А., Бадаева И. Ю. Гидробиологический режим выростных рыбоводных прудов при выращивании сеголетков в поликультуре // Сборник научных трудов ВНИИПРХ. 2005. Вып. 80. С. 94-102.

183. Тарасова О. М. Опыт совместного выращивания карпа и белого толстолобика // Рыбное хозяйство. 1970. Вып. 10. С. 39-42.

184. Тарасова О. М. Особенности питания белого толстолобика при выращивании его в поликультуре в прудах юга Украины : дис ... канд. биол. наук. Киев, $1971.171 \mathrm{c}$.

185. Терешенков И. И. Биологические основы товарного выращивания карпа, пеляди, белого амура и пестрого толстолобика в озерах Северо-Запада : автореф. дис. на соискание уч. степени канд. биол. наук. Ленинград, 1979. $20 \mathrm{c}$.

186. Технологический регламент выращивания товарной прудовой рыбы в поликультуре / Муратов В. М. и др. // Сборник научно-технологической и методической документации по аквакультуре в Беларуси. Минск : Тонпик, 2006. С. $42-50$.

187. Технология выращивания посадочного материала и товарного карпа в поликультуре с растительноядными рыбами на основе эффективного функционирования водных экосистем / Федорченко В. И. и др. // Сборник научно-технологической и методической документации по аквакультуре. Москва : ВНИРО, 2001. С. 53-59.

188. Технология выращивания рыбы в поликультуре с выходом 5-7 т/га в прудах 1-2 зон рыбоводства. Москва, 1986. 33 с.

189. Технология непрерывного выращивания рыбы в прудах 6-7 зон рыбоводства. Москва : ВНИИПРХ, 1989. 39 с.

190. Технологія вирощування товарної риби в ставах в полікультурі / Харитонова Н. М. та ін. Київ : Інститут рибного господарства УААН, 1996. 33 с.

191.Трансформация энергии первичной продукции в экосистеме нагульных прудов с интенсивной поликультурой карпа и растительноядных рыб / Степанов В. Д. и др. // Сборник научных трудов ВНИИПРХ. 2008. Вып. 84. С. $55-70$.

192. Тютюник С. Н., Ботезат В. А., Горюк Р. И. Совместное выращивание растительноядных рыб и карпа в прудах Молдрыбхозстанции // Биология и биотехника выращивания растительноядных рыб. Кишинев : Штиинца, 1972. C. $9-26$.

193. Тютюник С. Н., Степанова Г. М., Витковская Е. Д. Сезонная динамика питания и биохимических показателей растительноядных рыб при поликультуре в Молдавии // Итоги и перспективы рыбохозяйственного использования растительноядных рыб : 8 Всесоюз. совещ.: тезисы докл. Киев : Наукова думка, 1977. С. 122-124.

194. Федорченко В. И., Трубников А. И., Федорченко Ф. Г. Рыбоводные показатели рыбы при высоком уровне интенсификации в условиях моно- и поликультуры // Сборник научных трудов ВНИИПРХ. 1990. Вып. 60. С. $119-124$. 
195. Федорченко Ф. Г., Киселев А. Ю. Выращивание двухлетков карпа в поликультуре с преобладанием растительноядных рыб в условиях 1 зоны рыбоводства // Сборник научных трудов ВНИИПРХ. 2006. Вып. 81. С. 18 21.

196. Федорченко Ф. Г. Упитанность и химический состав сеголетков рыб, выращенных в поликультуре // Сборник научных трудов ВНИИПРХ. 2005. Вып. 80. С. $63-68$.

197. Филиппов К. К. Экологические основы прудовой поликультуры карпа и растительноядных рыб в Алтайском крае : автореф. дис. на соискание уч. степени канд. биол. наук. Москва : ВНИИПРХ, 1985. 23 с.

198. Филиппов К. К., Филиппова А. В. Прудовая поликультура и новые объекты рыбоводства в Алтайском крае // Первый конгресс ихтиологов России : тезисы докл. Астрахань, 1997. С. 300.

199. Филиппова А. В., Филиппов К. К. Растительноядные рыбы и буффало в водных экосистемах Алтайского края // 8 съезд Гидробиологического общества РАН : тезисы докл. Калининград, 2001. Т. 2. С. 66.

200. Формування гідрохімічного режиму ставів зони Полісся при вирощуванні риби в полікультурі за випасної технології з дволітнім циклом вирощування (на прикладі ВАТ Забір'я) / Литвинова Т. Г. та ін. // Рибне господарство. 2003. Вип. 62. С. 112-117.

201. Хабибулин Э. Т. Влияние карпа и белого амура на гидрохимический режим, первичную продукцию и рыбопродуктивность прудов Белоруссии : автореф. дис. на соискание уч. степени канд. биол. наук. Минск, 1980. 23 с.

202. Харитонова Н. М., Демченко І. Ф. Рекомендації по вирощуванню коропових риб в полікультурі при пасовищному утриманні. Київ : Інститут рибного господарства Української академії аграрних наук, 1993. 14 с.

203. Харитонова Н. Н., Блыскавка Е. А., Тарасова О. М. Питание и рост двухлеток карпа и белого амура при совместном выращивании // Рыбное хозяйство. 1968. Вып. 6. С. 112-117.

204. Харитонова Н. Н., Демченко И. Ф. Рекомендации по повышению рыбопродуктивности прудов при поликультуре рыб. Киев : Украинский научно-исследовательский институт рыбного хозяйства, 1993. 27 с.

205. Харитонова Н. Н., Иванов И. Н. Опыт выращивания растительноядных рыб совместно с карпом // Технология производства рыбы. Москва, 1974. С. $129-133$.

206. Хижняк М. І. Кількісний розвиток бактеріопланктону нагульних ставів при вирощуванні коропа в полікультурі 3 рослиноїдними рибами // Рибне господарство. 1999. Вип. 51. С. 73-85.

207. Чарыев Р., Рылов В. Г., Канода Н. Н. Опыт выращивания сеголетков растительноядных рыб совместно с карпом в прудах Туркменистана // Сборник научных трудов ВНИИПРХ. 1980. Вып. 60. С. 111-119.

208. Чертихин В. Г. Биологические особенности производства посадочного материала в поликультуре в условиях средней полосы // Рыбное хозяйство : информ. пакет. Москва, 1992. Вып. 2. С. 7-19. (Серия : Аквакультура. Прудовое и озерное рыбоводство).

209. Чертихин В. Г. Пищевые отношения гибрида толстолобиков с карпом при совместном выращивании в условиях средней полосы РСФСР // Сборник научных трудов ВНИИПРХ. 1977. Вып. 18. С. 116-131. 
210. Чертихин В. Г., Бай В. С., Мельченков Е. А. Первый опыт выращивания товарных двухлеток веслоноса в поликультуре (с белым и пестрым толстолобиками, белым амуром и карпом) // Рыбное хозяйство : информ. пакет. Москва, 1992. Вып. 3. С. 24-31. (Серия : Аквакультура. Прудовое и озерное рыбоводство).

211. Чертихин В. Г., Мельченков Е. А., Шаговский С. В. Поликультура растительноядных рыб, карпа и веслоноса при товарном выращивании // Проблемы воспроизводства растительноядных рыб, их роль в аквакультуре : конф. : матер. докл. Адлер, 2000. С. 133-135.

212. Чижик А. К., Шерман И. М., Щечка Е. И. К вопросу изучения эффективности поликультуры в высокоминерализованных выростных прудах // Итоги и перспективы рыбохозяйственного использования растительноядных рыб : 8 Всесоюз. совещ. : тезисы докл. Киев : Наукова думка, 1977. С. 138-139.

213. Шандрук О. М. Перспективи пасовищного вирощування ставкових риб в полікультурі в рибницькому господарстві агрофірми «Зоря» // Таврійський науковий вісник. 1999. Вип. 10. С. 119-122.

214. Шандрук О. М., Гриб Й. В., Борбат М. О. До питання розрахунку щільності посадки коропових риб у полікультурі // Рибогосподарська наука України. 2011. № 4. С. $69-72$.

215. Шекк П. В., Бургаз М. И. Уменьшение органического загрязнения мелководных акваторий солоноватоводных лиманов при выращивании рыб в садках в поликультуре // Рибогосподарська наука України. 2017. № 2. С. 2938.

216. Шерман И. М. Выращивание сеголеток белого амура в монокультуре и совместно с карпом на юге Украины // Рыбное хозяйство. 1971. Вып. 12. С. $78-80$.

217. Шерман И. М. О питании сеголеток белого амура и леща при совместном выращивании // Рыбное хозяйство. 1971. Вып. 13. С. 45-50.

218. Шмакова 3. И. Влияние разных факторов и технологических приемов на выращивание сеголетков в прудовой поликультуре (обзор) // Сборник научных трудов ВНИИПРХ. 2006. Вып. 81. С. 21-28.

219. Шмакова 3. И. Естественная кормовая база и ее роль в питании рыб, выращиваемых в поликультуре // Проблемы воспроизводства растительноядных рыб, их роль в аквакультуре : конф. : матер. докл. Адлер, 2000. С. $139-141$.

220. Янінович Й. Є. Інтенсифікація ставового рибництва шляхом впровадження полікультури // Рибогосподарська наука України. 2010. № 1. С. 79-82.

221. Янінович Й. Є. Підвищення ефективності ставового рибництва за рахунок розширення полікультури риб : автореф. дис. на здобуття наук. ступеня канд. с.-г. наук. Київ : Інститут рибного господарства НААНУ, 2012. 20 с.

222. Янінович Й. Є., Гринжевський М. В., Швець Т. М. Прибутки від полікультури в рибництві // Рибогосподарська наука України. 2011. № 1. С. $89-95$.

223. Янінович Й. Є., Грициняк I. І., Гринжевський М. В. Ставова полікультура. Львів : Сполом, 2011. $191 \mathrm{c.}$

224. Янінович Й. Є., Качай Г. В., Швець Т. М. Енергетична цінність м’яса риб, вирощених у полікультурі // Рибогосподарська наука України. 2011. № 2. С. $122-126$. 
225. Янінович Й. Є., Швець Т. М. Підвищення вагових кондицій українських коропів, вирощених у полікультурі // Рибне господарство. 2009. Вип. 67. С. $210-214$.

\section{REFERENCES}

1. Mamedov, R. A., \& et al. (2009). Abioticheskie i bioticheskie usloviya vyrashchivaniya segoletok sudaka v prudovoy polikul'ture ryb. Voprosy rybnogo khozyaystva Belarusi, 25, 128-136.

2. Azizov, F. F., \& Radzhabov, F. M. (2017). Vyrashchivanie polikul'tury karpovykh ryb $\mathrm{v}$ usloviyakh Gissarskoy doliny Tadzhikistana. Rybovodstvo $i$ rybnoe khozyaystvo, 7, 39-46.

3. Alimov, I. A. (2010). Opyt vyrashchivaniya segoletkov vyrezuba v polikul'ture. Nauchnye osnovy sel'skokhozyaystvennogo rybovodstva: sostoyanie i perspektivy razvitiya: sbornik nauchnykh trudov. Moskva, 143-146.

4. Altukhov, K. A. (1972). Effektivnost' primeneniya polikul'tury rastitel'noyadnykh ryb v prudakh zapadnykh oblastey USSR. Rybnoe khozyaystvo, 14, 52-59.

5. Alkhimov, Yu. M., Neznamov, S. O., \& Sherman, I. M. (2013). Gustota posadki i spivvidnoshennya komponentiv polikul'turi u stavakh natorfyanikh i pishchanikh gruntakh pri viroshchuvanni ts'ogolitok koropovikh rib. Ribogospodars'ka nauka Ukrainy, 2, 66-69.

6. Al'-Khashimi Sabakh Khamil' Ismail. (1974). Pitanie i pishchevye vzaimootnosheniya segoletkov karpa i rastitel'noyadnykh ryb pri sovmestnom vyrashchivanii v prudakh Kievskogo Poles'ya. Extended abstract of candidate's thesis. Leningrad: GosNIORKh.

7. Artamonova, T. I., \& Kiselev, A. Yu. (2005). Khimicheskiy sostav i kaloriynost' tela ryb, vyrashchennykh v polikul'ture po tekhnologii, netraditsionnoy dlya 1 zony rybovodstva. Sbornik nauchnykh trudov VNIIPRKh, 80, 39-46.

8. Artamonova, T. I., Ovinnikova, V. V., \& Fedorchenko, F. G. (2002). Osobennosti pitaniya dvukh- i trekhletok belogo amura i karpa, vyrashchivaemykh v usloviyakh netraditsionnoy polikul'tury. Sbornik nauchnykh trudov VNIIPRKh, 78, 6-11.

9. Ba, M. L., Tomedi, E. M., \& Tikhomirov, A. M. (2000). Opyt vyrashchivaniya bestera v polikul'ture s belym amurom na Chaganskom rybopitomnike. Osetrovye na rubezhe XXI v.: Mezhdunar. konf.: tezisy dokl. Astrakhan', 293-294.

10. Babiy, A. A. (1987). Morfo-biologicheskie osobennosti gibrida pelyad'×sig kak ob"ekta polikul'tury ozernogo tovarnogo rybovodstva. Extended abstract of candidate's thesis. Moskva: VNIIPRKh.

11. Bayramov, R. A., \& Kiselev, A. Yu. (2008). Vliyanie faktorov sredy i razmernykh kharakteristik pruda na ego ryboproduktivnost' $\mathrm{v}$ usloviyakh polikul'tury. Rybovodstvo i rybnoe khozyaystvo, 2, 31-33.

12. Bardachev, Yu. N., Rogal'skiy, F. B., \& Didyk, A. A. (2008). Metody formirovaniya sostava polikul'tury tovarnoy ryby v vodoeme. Sovremennye problemy gidrobiologii. Perspektivy, puti i metody resheniy-2: Mezhdun. nauchn. konf.: mater. Kherson, 49-51.

13. Bekin, A. G., \& Vundtsettel', M. F. (2000). Effektivnost' ispol'zovaniya prudovykh ekosistem pri razlichnykh tipakh polikul'tury. Problemy vosproizvodstva rastitel'noyadnykh ryb, ikh rol'v akvakul'ture: konf.: mater. dokl. Adler, 62-64. 
14. Ber, S. B., Magomaev, F. M., \& Abdusamadov, A. S. (1981). Effektivnost' ispol'zovaniya mineral'nykh udobreniy pri vyrashchivanii segoletkov rastitel'noyadnykh ryb v polikul'ture s karpom v Dagestanskoy ASSR. Sbornik nauchnykh trudov VNIIPRKh, 31, 59-67.

15. Biologicheskie osnovy i obshchaya kharakteristika polikul'turnogo rybovodstva. (2000). Rukovodstvo po biotekhnike razvedeniya $i$ vyrashchivaniya dal'nevostochnykh rastitel'noyadnykh ryb. Moskva: VNIIPRKh, 150-155.

16. Blinova, R. D., Burlakova, A. N., \& Zaytseva, E. M. (1980). Pishchevye otnosheniya segoletkov karpa i chernogo buffalo pri sovmestnom vyrashchivanii v usloviyakh Srednego Povolzh'ya. Sbornik nauchnykh trudov GosNIORKh, 158, 7075.

17. Bobrova, Yu. P. (1966). Vyrashchivanie belogo amura v polikul'ture s drugimi rybami v prudakh Moskovskoy obl. Trudy VNIIPRKh, 14, 3-14.

18. Bogeruk, A. K., Kamekho, S., \& Uliver, S. (1981). Opyt polikul'turnogo vyrashchivaniya ryby $\mathrm{v}$ malom vodokhranilishche Respubliki Kuba. Sbornik nauchnykh trudov VNIIPRKh, 31, 254-264.

19. Borovik, E. A. (1970). Raduzhnaya forel' - tsennaya dobavochnaya ryba k karpu. Trudy BelNIIRKh, 7, 266-270.

20. Bortnik, A. F. (1986). Polikul'tura rastitel'noyadnykh ryb v vodoemakhokhladitelyakh GRES. Extended abstract of candidate's thesis. Moskva: VNIIPRKh.

21. Bulatovich, M. A. (1979). Razvitie fitoplanktona $\mathrm{v}$ nagul'nykh prudakh pri vyrashchivanii ryb v polikul'ture. Rybnoe khozyaystvo, 29, 54-58.

22. Vasil'eva, L. M., Sokol'skiy, A. F., \& Mednaya, L. I. (1997). Vyrashchivanie veslonosa sovmestno $s$ karpom $i$ rastitel'noyadnymi rybami $v$ prudovykh khozyaystvakh Astrakhanskoy oblasti: metodicheskie ukazaniya. Astrakhan': BIOS.

23. Verigin, B. V., \& Pushkar', V. Ya. (1977). Upravlenie produktivnost'yu ekosistemy prudovykh vodoemov $\mathrm{i}$ formy polikul'tury. Itogi $i$ perspektivy rybokhozyaystvennogo ispol'zovaniya rastitel'noyadnykh ryb: 8 Vsesoyuz. soveshch.: tezisy dokl. Kiev: Naukova dumka, 34-35.

24. Vinogradov, V. K. (1999). Pastbishchnaya tekhnologiya vyrashchivaniya ryby. Aktual'nye aspekty ryborazvedeniya v sovremennykh usloviyakh. Sankt-Peterburg: KrasNIIRKh; GosNIORKh, 152-154.

25. Vinogradov, V. K. (1975). Polikul'tura rastitel'noyadnykh ryb v prudovom rybovodstve i estestvennykh vodoemakh. Sbornik nauchnykh trudov VNIIPRKh, $15,3-19$.

26. Vinogradov, V. K., Voropaev, N. V., \& Danchenko, A. D. (1977). Materialy k trofologicheskomu analizu polikul'tury $\mathrm{v}$ prudovom rybovodstve. Itogi i perspektivy rybokhozyaystvennogo ispol'zovaniya rastitel'noyadnykh ryb: 8 Vsesoyuz. soveshch.: tezisy dokl. Kiev: Naukova dumka, 35-37.

27. Vinogradov, V. K., \& Erokhina, L. V. (1999). Optimizatsiya vidovogo i kolichestvennogo sostava polikul'tury kak metod povysheniya effektivnosti tovarnogo rybovodstva. Resursosberegayushchie tekhnologii $v$ akvakul'ture: simpoz.: mater. dokl. Adler, 25.

28. Vladovskaya, S. A., \& Gamayun, E. P. (1980). Ispol'zovanie shchuki v usloviyakh intensivnogo rybovodstva ( $\mathrm{v}$ t. ch. zarubezhnyy opyt). Rybnoe khozyaystvo: obzornaya informatsiya. Seriya: Rybokhozyaystvennoe ispol'zovanie vnutrennikh vodoemov. (Vol. 2). Moskva. 
29. Vlasov, V. A. (2012). Polikul'tura v prudovom rybovodstve. Rybovodstvo: ucheb. posobie. Sankt-Peterburg: Lan', 152-157.

30. Vlasov, V. A., \& Lesin, K. M. (1997). Ispol'zovanie polikul'tury v prudovom rybovodnom khozyaystve 2 zony rybovodstva. Rybnoe khozyaystvo: informatsionnyy paket. Seriya: Akvakul'tura (Vol. 1). Moskva, 58-60.

31. Kharitonova, N. N., et al. (1988). Vliyanie azotno-fosfornykh i kaliynykh udobreniy na produktivnost' prudov pri polikul'ture ryb. Rybnoe khozyaystvo, 42, 15-20.

32. Voynarovich, A., Mot-Poul'sen, T., \& Peteri, A. (2014). Polikul'tura karpovykh ryb v stranakh Tsentral'noy i Vostochnoy Evropy, Kavkaza i Tsentral'noy Azii. Rukovodstvo. Tekhnicheskiy dokument FAO po rybolovstvu i akvakul'ture № 554 . Rim: FAO.

33. Voronin, V. M. (1985). Razmernaya struktura stada rastitel'noyadnykh ryb v prudovoy polikul'ture. Extended abstract of candidate's thesis. Moskva: VNIIPRKh.

34. Voronin, V. M., \& Tolchinskiy, G. I. (1983). Razmernaya struktura stada segoletkov rastitel'noyadnykh ryb v prudovoy polikul'ture. Sbornik nauchnykh trudov VNIIPRKh, 38, 41-51.

35. Voronova, G. P., Kutsko, L. A., \& Panteley, S. N. (2013). Vyrashchivanie tovarnoy ryby na estestvennykh kormakh v usloviyakh netraditsionnoy polikul'tury vo vtoroy rybovodnoy zone Belarusi. Rybovodstvo i rybnoe khozyaystvo, 9, 28-33.

36. Voronova, G. P., Kutsko, L. A., \& Panteley, S. N. (2011). O tekhnologicheskikh priemakh vyrashchivaniya belogo amura $\mathrm{v}$ polikul'ture ryb $\mathrm{s}$ ispol'zovaniem zelenykh kormov nazemnoy rastitel'nosti. Voprosy rybnogo khozyaystva Belarusi, 27, 50-58.

37. Artamonova, T. I., et al. (2010). Vyrashchivanie gibridnykh form karasekarpa v polikul'ture s karpom v pervoy zone rybovodstva. Sbornik nauchnykh trudov VNIIPRKh, 85, 18-33.

38. Fedorchenko, V. I., et al. (2002). Vyrashchivaniya dvukhletok belogo amura v polikul'ture v 1 zone rybovodstva. Sbornik nauchnykh trudov VNIIPRKh, 78, 15-20.

39. Gorbacheva, L. T., et al. (2000). Vyrashchivanie molodi osetra v polikul'ture s belym amurom. Problemy vosproizvodstva rastitel'noyadnykh ryb, ikh rol' $v$ akvakul'ture: konf.: mater. dokl. Adler, 68-70.

40. Shmakova, Z. I., et al. (2002). Vyrashchivanie segoletok belogo amura v polikul'ture pri napravlennom formirovanii kormovoy bazy vyrostnykh prudov. Sbornik nauchnykh trudov VNIIPRKh, 78, 20-29.

41. Konchits, V. V., et al. (2000). Vyrashchivanie tovarnoy prudovoy ryby V polikul'ture $\mathrm{s}$ ispol'zovaniem resursosberegayushchey tekhnologii. Problemy vosproizvodstva rastitel'noyadnykh ryb, ikh rol'v akvakul'ture: konf.: mater. dokl. Adler, 81-83.

42. Mishchenko, N. V., et al. (1984). Vyrashchivanie tovarnoy ryby v polikul'ture. Rybnoe khozyaystvo, 6, 45-46.

43. Galkovskaya, G. A., \& Sobolev, Yu. A. (1972). Osobennosti formirovaniya soobshchestva zooplanktona pri polikul'ture karpa s rastitel'noyadnymi rybami. Trudy BelNIIRKh, 8, 73-81.

44. Giryaev, A. S. (1990). Fiziologo-biokhimicheskaya kharakteristika molodi karpovykh ryb, vyrashchivaemykh v polikul'ture v usloviyakh 2-4 zon rybovodstva. Extended abstract of candidate's thesis. Moskva: VNIIPRKh. 
45. Grinzhevs'kiy, M. V., \& Pshenichniy, D. R. (2007). Viroshchuvannya dvolitok koropovo-sazanovikh gibridiv u polikul'turi. Ribogospodars'ka nauka Ukrainy, 1, 41-45.

46. Grinzhevs'kiy, M. V., Yaninovich, Y. YE., \& Shvets', T. M. (2009). Polikul'tura z shist'okh vidiv rib. Ribogospodars 'ka nauka Ukrainy, 1, 38-42.

47. Grinzhevs'kiy, M. V., Yaninovich, Y. YE., \& Shvets', T. M. (2008). Efektivnist' stavovoi polikul'turi. Ribogospodars 'ka nauka Ukrainy, 2, 41-44.

48. Grobokopatel', M. G., \& Balan, O. I. (1973). Roslinoidni ribi i korop - vigidni susidi. Tvarinnitstvo Ukrainy, 12, 44-45.

49. Grobokopatel', M. G., \& Prokopenko, A. A. (1975). Effektivnost' vyrashchivaniya trekhletkov pestrogo tolstolobika v polikul'ture v opytnom khozyaystve «Nivka». Rybnoe khozyaystvo, 21, 111-113.

50. Guzyur, Ya., \& Voznyak, M. (1999). Vyrashchivanie rechnogo yazya (Leuciscus idus L.) v prudovoy polikul'ture v severnoy zone Pol'shi (Ol'shtynskaya oblast'). Sovremennoe sostoyanie i perspektivy razvitiya akvakul'tury. Gorki, 102-104.

51. Danchenko, A. D. (1976). Osobennosti povedeniya i skata segoletkov rastitel'noyadnykh ryb i karpa pri vyrashchivanii v polikul'ture. Trudy VNIIPRKh, 25, 41-49.

52. Danchenko, A. D. (1976). Pitanie i pishchevye vzaimootnosheniya segoletkov rastitel'noyadnykh ryb i karpa pri vyrashchivanii v polikul'ture. Trudy VNIIPRKh, $25,50-58$.

53. Danchenko, A. D. (1974). Polikul'tura rastitel'noyadnykh ryb kak metod intensifikatsii prudovogo rybovodstva (na primere rybkhozov Krasnodarskogo kraya i Kuybyshevskoy oblasti). Extended abstract of candidate's thesis. Kaliningrad.

54. Danchenko, A. D. (1974). Polikul'tura rastitel'noyadnykh ryb kak metod intensifikatsii prudovogo rybovodstva (na primere rybkhozov Krasnodarskogo kraya i Kuybyshevskoy oblasti). Extended abstract of candidate's thesis. Kaliningrad: Kaliningradskiy tekhnicheskiy institut rybnoy promyshlennosti i khozyaystva.

55. Dao Suan Lok, \& Nosal', A. D. (1974). Vyrashchivanie posadochnogo materiala rastitel'noyadnykh ryb v polikul'ture s karpom v prudakh Ukrainskogo Poles'ya. Tekhnologiya proizvodstva ryby. Moskva, 123-129.

56. Dem'yanenko, V. F. (1999). Tekhnologiya kombinirovannogo vyrashchivaniya ryby s ispol'zovaniem teplykh vod v zone umerennogo klimata. Aktual'nye aspekty ryborazvedeniya $v$ sovremennykh usloviyakh. Sankt-Peterburg: KrasNIIRKh; GosNIORKh, 124-151.

57. Dzhana, V. V., \& Roy, S. K. (1983). Rost ryb v rybovodnykh prudakh s polikul'turoy $\mathrm{V}$ zavisimosti ot chislennosti bakteriy, uchastvuyushchikh V krugovorote azota. Gidrobiologicheskiy zhurnal, 2, 106-108.

58. Dulon, R., \& Zav'yalov, A. P. (2018). Chislennost' i vidovoy sostav fito- i zooplanktona pri vyrashchivanii karpovykh ryb $\mathrm{v}$ polikul'ture $\mathrm{v}$ usloviyakh nespusknykh vodoemov respubliki Bangladesh. Rybovodstvo i rybnoe khozyaystvo, 2, 24-32.

59. Elovenko, V. N. (2006). Khishchniki v prudovoy polikul'ture. Rybovodstvo i rybnoe khozyaystvo, 2, 39.

60. Emtyl', M. Kh. (1987). Buffalo kak ob"ekt prudovoy polikul'tury (na primere rybkhozov Krasnodarskogo kraya). Extended abstract of candidate's thesis. Moskva: VNIIPRKh. 
61. Zhigin, A. V. (2003). Opyt vyrashchivaniya sibirskogo osetra v polikul'ture s tilyapiey. Sozdanie i ekspluatatsiya remontno-matochnykh stad osetrovykh ryb $s$ ispol'zovaniem teplykh vod razlichnogo proiskhozhdeniya: nauch.-prakt. konf., 2223 dek. 2003 g.: mater. Sankt-Peterburg: GosNIORKh, 22-26.

62. Zhigin, A. V., \& Terent'ev, V. P. (2015). Polikul'tura ryb v vodoeme. Rybovodnorybolovnoe rekreatsionnoe khozyaystvo. Moskva: VNIRO.

63. Zhigin, A. V., \& Terent'ev, V. P. (2015). Funktsional'naya znachimost' vidov v polikul'ture vodoema. Rybovodno-rybolovnoe rekreatsionnoe khozyaystvo. Moskva: VNIRO.

64. Zhukov, P. I. (2000). Raschet optimal'noy plotnosti posadki ryb pri vyrashchivanii v polikul'ture. Voprosy rybnogo khozyaystva Belarusi, 16, 13-16.

65. Gankevich, B. O., et al. (2009). Z dosvidu viroshchuvannya tovarnogo veslonosa $\mathrm{v}$ stavoviy polikul'turi lisostepovoi zoni. Ribogospodars 'ka nauka Ukrainy, 4, 70-76.

66. Rechinskiy, V. V. et al. (2005). Izmenenie sostava prudovoy polikul'tury na yuge Rossii. Aktual'ni problemi akvakul'turi ta ratsional'nogo vikoristannya vodnikh bioresursiv: Mizhnar. konf., m. Kyiv, 26-30 ver. 2005 r.: mater. Kyiv: IRG UAAN, 2005. S. 220-222.

67. Kozhokaru, T. T., et al. (1982). Izuchenie optimal'noy polikul'tury molodi pri vysokoy stepeni intensifikatsii vyrostnykh prudov. Sovershenstvovanie tekhnologii vyrashchivaniya ryb pri vysokoy stepeni intensifikatsii. Kishinev, 11-12.

68. Karmen, N., et al. (2008). Izuchenie rosta amerikanskogo veslonosa (Polyodon spathula) na pervom godu vyrashchivaniya $\mathrm{v}$ polikul'ture. Voprosy rybnogo khozyaystva Belarusi, 24, 233-236.

69. Irikhimovich, A. I., \& Tyutyunik, S. N. (1970). Materialy k nagulu ryb dal'nevostochnogo kompleksa sovmestno s karpami v prudakh Moldavii. Sbornik nauchno-issledovatel'skikh trudov VNIIPRKh, 4, 102-111.

70. Kaplich, V. M., Zvyagintsev, V. B., \& Gerasimchik, V. A. (2012). Polikul'tura i dobavochnye vidy ryb. Osnovy rybovodstva i rybolovstva: ucheb. posobie. Minsk: BGTU, 85.

71. Kiseleva, L. A. (1990). Vliyanie kormovoy bazy v prudakh na vyrashchivanie rastitel'noyadnykh ryb v polikul'ture s karpom. Sbornik nauchnykh trudov VNIIPRKh, 59, 67-68.

72. Kovalenko, V. O. (2003). Do pitannya pro mistse koropa v stavkoviy polikul'turi tovarnogo ribnitstva. Ribne gospodarstvo Ukrainy, 6, 18-20.

73. Kozhin, N. I. (1971). Vyrashchivanie molodi v monokul'ture i polikul'ture. Spravochnik rybovoda po iskusstvennomu razvedeniyu promyslovykh ryb. Moskva: Pishchevaya promyshlennost', 144-146.

74. Kozhokaru, E. V., Mikhaylovskiy, N. M., \& Yalovitskaya, N. I. (1977). Vliyanie mineral'nykh udobreniy na fitoplankton prudov pri sovmestnom vyrashchivanii segoletok tolstolobikov $\mathrm{i}$ karpa. Itogi $i$ perspektivy rybokhozyaystvennogo ispol'zovaniya rastitel'noyadnykh ryb: 8 Vsesoyuz. soveshch.: tezisy dokl. Kiev: Naukova dumka, 71-73.

75. Kozhokaru, T. T. (1977). Vliyanie chastoty vneseniya udobreniy na ryboproduktivnost' prudov pri polikul'ture ryb. Itogi $i$ perspektivy rybokhozyaystvennogo ispol'zovaniya rastitel'noyadnykh ryb: 8 Vsesoyuz. soveshch.: tezisy dokl. Kiev: Naukova dumka, 70-71.

76. Kozlov, V. I. (2004). Biotekhnika vyrashchivaniya segoletkov rastitel'noyadnykh ryb v polikul'ture s karpom. Akvakul'tura. Moskva: MGUTU, 121-123. 
77. Kozlov, V. I. (2004). Novye formy polikul'tury. Akvakul'tura. Moskva: MGUTU, 128-131.

78. Kozlov, V. I. (1999). Rekomendatsii po tekhnologii proizvodstva ryby bez primeneniya kombikormov s vykhodom 6-8 ts/ga v rybovodnykh khozyaystvakh Nechernozemnoy zony Rossii. Aktual'nye aspekty ryborazvedeniya v sovremennykh usloviyakh. Sankt-Peterburg: KrasNIIRKh; GosNIORKh, 86-89.

79. Konchits, V. V. (1999). Vyrashchivanie tovarnykh rastitel'noyadnykh ryb v polikul'ture s karpom. Rastitel'noyadnye ryby kak osnova intensifikatsii rybovodstva Belarusi. Minsk: Khata, 198-224.

80. Konchits, V. V. (2000). O vozmozhnom napravlenii rasshireniya vnedreniya rastitel'noyadnykh ryb v polikul'turu ryborazvedeniya Belarusi. Problemy vosproizvodstva rastitel'noyadnykh ryb, ikh rol'v akvakul'ture: konf.: mater. dokl. Adler, 26-27.

81. Konchits, V. V. (2005). Povyshenie produktivnosti prudov za schet polikul'tury osnovnykh i dobavochnykh vidov ryb. Akvakul'tura $v$ Belarusi. Minsk: Belorusskaya nauka, 58-70.

82. Konchits, V. V. (2008). Effektivnost' primeneniya polikul'tury i vnedreniya novykh ob"ektov rybovodstva. Voprosy rybnogo khozyaystva Belarusi, 24, 105-109.

83. Zhemaeva, N. P., et al. (2002). Kormovaya baza i pitanie segoletkov chernogo amura pri vyrashchivanii v polikul'ture. Problemy akvakul'tury i funktsionirovaniya vodnykh ekosistem: Mezhdunar. nauch.-prakt. konf. molodykh uchenykh, 25-28 fevr. 2002 g.: mater. Kiev, 22-23.

84. Korolev, A. E. (1984). Energeticheskiy balans i ratsiony molodi sudaka i pelyadi pri ikh sovmestnom vyrashchivanii $\mathrm{v}$ prudu. Sbornik nauchnykh trudov GosNIORKh, 22, 21-30.

85. Korolev, A. P., \& Khodyachiy, N. P. (1981). Polikul'turnoe rybovodstvo rentabel'naya otrasl'. Moskva: Legkaya i pishchevaya promyshlennost'.

86. Korol'kova, M. S., Ovinnikova, V. V., \& Voronkov, L. A. (1991). Sostav polikul'tury pri proizvodstve tovarnogo karpa massoy bolee $600 \mathrm{~g}$ pri dvukhletnem vyrashchivanii. Sbornik nauchnykh trudov VNIIPRKh, 61, 95-103.

87. Kostylev, V. A., Barsov, I. G., \& Shnitov, B. I. (1981). Osobennosti podrashchivaniya molodi i vyrashchivaniya posadochnogo materiala karpa i rastitel'noyadnykh ryb v teplovodnom khozyaystve. Sbornik nauchnykh trudov VNIIPRKh, 30, 52-62.

88. Kosyreva, R. Ya. (1958). Pitanie molodi sudaka pri vyrashchivanii ee v nerestovovyrostnykh khozyaystvakh sovmestno s drugimi vidami ryb. Extended abstract of candidate's thesis. Moskva.

89. Krazhan, S. A., \& Sisoeva, O. M. (1999). Zhivlennya ts'ogolitok koropa pri viroshchuvanni $\mathrm{v}$ polikul'turi u stavakh Lisostepovoi zoni Ukrainy. Ribne gospodarstvo, 49-50, 153-157.

90. Krazhan, S. A., Khizhnyak, M. I., \& Gorobets', L. V. (2000). Rozvitok prirodnoi kormovoi bazi staviv lisostepovoi zoni Ukraini pri viroshchuvanni ts'ogolitok koropa ta roslinoidnikh rib u polikul'turi. Ribne gospodarstvo, 58, 66-72.

91. Kubarskiy, I. F. (1972). Opyt vyrashchivaniya tolstolobikov sovmestno s karpom v prudakh rybkhoza «Zhovtnevo». Rybnoe khozyaystvo, 15, 37-39.

92. Kuz'min, I. A. (2005). Povyshenie produktivnosti vyrostnykh prudov putem napravlennogo vozdeystviya na ekosistemu. Akvakul'tura i integrirovannye tekhnologii: problemy i vozmozhnosti: konf.: mater. (Vol. 2). Moskva, 147-153. 
93. Kulesh, V. F., \& Alekhnovich, A. V. (2010). Vyrashchivanie molodi dlinnopalogo raka (Astacus leptodactylus) $\mathrm{v}$ sadkakh i prudakh $\mathrm{v}$ polikul'ture $\mathrm{s}$ ryboy na podogretykh sbrosnykh vodakh teploelektrostantsii. Gidrobiologicheskiy zhurnal, $1,47-61$.

94. Kurinenko, G. A., Mruk, A. I., \& Kolos, O. M. (2016). Viroshchuvannya pelyadi (Coregonus peled Gmelin) v polikul'turi z koropovimi (Cyprinidae) ta osetrovimi (Acipenseridae) ribami. Ribogospodars 'ka nauka Ukrainy, 1, 43-56.

95. Kutsko, L. A., \& Panteley, S. N. (2006). Formirovanie gidrokhimicheskogo rezhima prudov pri pastbishchnom vyrashchivanii tovarnoy ryby $\mathrm{v}$ polikul'ture. Voprosy rybnogo khozyaystva Belarusi, 22, 174-183.

96. Kucherenko, N. S. (1972). O vliyanii pestrogo i belogo tolstolobikov na rost karpa pri sovmestnom vyrashchivanii. Sbornik nauchnykh trudov VNIIPRKh, 2, 50-59.

97. Lebedeva, I. (1970). Chto dala polikul'tura. Rybovodstvo i rybolovstvo, 2, 20.

98. Litvinenko, A. I. (1999). Instruktsiya po intensivnomu podrashchivaniyu molodi karpa i rastitel'noyadnykh ryb $\mathrm{v}$ prudakh $\mathrm{s}$ geotermal'nym vodosnabzheniem. Aktual'nye aspekty ryborazvedeniya v sovremennykh usloviyakh. Sankt-Peterburg: KrasNIIRKh; GosNIORKh, 30-34.

99. Loshkova, Yu. M. (2016). Tekhnologo-biologichni aspekti viroshchuvannya dvolitok koropovikh rib u polikul'turi dlya zaribnennya vodoym ponizzya Dnipra. Extended abstract of candidate's thesis. Kyiv: Institut ribnogo gospodarstva NAAN.

100. Lupacheva, L. I. (1970). Pishchevye otnosheniya lichinok belogo tolstolobika i belogo amura pri sovmestnom vyrashchivanii. Rybnoe khozyaystvo, 11, 34-37.

101. Magomaev, F. M. (1977). Vnedrenie polikul'tury rastitel'noyadnykh ryb vo vnutrennie vodoemy Dagestana. Itogi $i$ perspektivy rybokhozyaystvennogo ispol'zovaniya rastitel'noyadnykh ryb: 8 Vsesoyuz. soveshch.: tezisy dokl. Kiev: Naukova dumka, 86-87.

102. Magomaev, F. M., Ber, S. B., \& Shchashchaev, Yu. A. (1979). Vyrashchivanie ryboposadochnogo materiala rastitel'noyadnykh ryb $\mathrm{v}$ polikul'ture $\mathrm{s}$ karpom $\mathrm{v}$ Dagestane. Sbornik nauchnykh trudov VNIIPRKh, 26, 158-167.

103. Mamedov, R. A., \& Minaev, O. V. (2008). Opyt vyrashchivaniya segoletkov sudaka v polikul'ture. Voprosy rybnogo khozyaystva Belarusi, 24, 134-138.

104. Mamontov, Yu. P., Alymov, S. I., \& Zakharov, V. S. (2012). Raschety norm posadki ryby $\mathrm{v}$ vyrostnye i nagul'nye prudy pri mono- i polikul'ture. Metody povysheniya effektivnosti prudovogo rybovodstva. Moskva: Rosinformagrotekh.

105. Mamontova, R. P. (2009). Zoobentos nagul'nykh prudov s polikul'turoy ryb. Innovatsionnye tekhnologii akvakul'tury: Mezhdunar. nauch. konf., 21-22 sent. 2009 g.: tezisy dokl. Rostov-na-Donu: YuNTs RAN, 89-92.

106. Mamontova, R. P., Artamonova, T. I., \& Trubnikova, M. K. (2011). Estestvennaya kormovaya baza prudov i osobennosti pishchevykh vzaimootnosheniy gibrida karasekarpa pri vyrashchivanii v polikul'ture s karpom. Sbornik nauchnykh trudov VNIIPRKh, 86, 10-19.

107. Maslova, N. I. (2006). Biologicheskaya kharakteristika linya - ob"ekta akvakul'tury (polikul'tura). Pribrezhnoe rybolovstvo i akvakul'tura: obzor. inform., 1, 1-41.

108. Maslova, N. I., \& Servetnik, G. E. (2016). Rybovodno-biologicheskaya otsenka vidov ryb, prigodnykh dlya vyrashchivaniya v polikul'ture (yaz', lin', shchuka): monografiya. Moskva: RGAU-MSKhA.

109. Maslova, N. I., Servetnik, G. E., \& Petrushin, A. B. (2002). Ekologo-biologicheskie osnovy polikul'turnogo rybovodstva. Moskva. 
110. Maslova, N. I., Servetnik, G. E., \& Petrushin, A. B. (2001). Ekologo-landshaftnye osobennosti vodoemov i polikul'tura ryb. Rybokhozyaystvennoe ispol'zovanie vodoemov kompleksnogo naznacheniya: sbornik. (Part 2). Moskva, 155-173.

111. Medvedev, M. G., Kravchuk, N. M., \& Tretyak, O. M. (1999). Zastosuvannya optimizatsiynogo modelyuvannya pri viznachenni shchil'nostey posadki ob'yektiv polikul'turi za vipasnogo viroshchuvannya ribi v stavakh. Ribne gospodarstvo, 54$55,140-145$.

112. Mel'chenkov, E. A., Arkhangel'skiy, V. V., \& Miniyarov, F. T. (2002). Veslonos kak ob"ekt tovarnogo vyrashchivaniya v polikul'ture. Sbornik nauchnykh trudov VNIIPRKh, 78, 66-69.

113. Mel'chenkov, E. A., \& Chertikhin, V. G. (2000). Razvodite veslonosa. Rybovodstvo i rybolovstvo, 1, 20.

114. Metodicheskie ukazaniya po formirovaniyu estestvennoy kormovoy bazy dlya amura v polikul'ture vyrostnykh prudov VII zony rybovodstva. (1987). Moskva.

115. Milanovskiy, Yu. E. (1974). Ispol'zovanie ryb-fitofagov v prudovoy polikul'ture. Zoologiya pozvonochnykh. (Vol. 5). Moskva, 95-135.

116. Milanovskiy, Yu. E., \& Pushkar', V. Ya. (1977). Kharakteristika usloviy pitaniya tolstolobika kak osnova tekhnologicheskogo kontrolya polikul'tury ryb. Itogi $i$ perspektivy rybokhozyaystvennogo ispol'zovaniya rastitel'noyadnykh ryb: 8 Vsesoyuz. soveshch.: tezisy dokl. Kiev: Naukova dumka, 91-93.

117. Miniyarov, F. T., \& Man'shina, A. A. (2000). Razrabotka bionormativov rentabel'nogo vyrashchivaniya osetrovykh ryb v polikul'ture $\mathrm{s}$ rastitel'noyadnymi rybami. Osetrovye na rubezhe XXI v.: Mezhdunar. konf.: tezisy dokl. Astrakhan', 308-309.

118. Miniyarov, F. T., Shcherbatova, T. G., \& Kitanov, A. A. (2001). Polikul'tura pri tovarnom vyrashchivanii $\mathrm{v}$ osetrovykh prudakh. Akvakul'tura osetrovykh ryb: dostizheniya i perspektivy razvitiya: Vtoraya Mezhdunar. nauch.-prakt. konf., 21-22 noyab. 2001 g.: mater. Astrakhan': BIOS; Nova, 104-106.

119. Mikhaylovskiy, N. M., Kozhokaru, E. V., \& Kalenik, T. I. (1982). Vyrashchivanie segoletok $\mathrm{V}$ polikul'ture $\mathrm{s}$ preobladaniem tolstolobikov $\mathrm{v}$ Pridnestrovskom rybkhoze. Sovershenstvovanie tekhnologii vyrashchivaniya ryb pri vysokoy stepeni intensifikatsii. Kishinev, 48-55.

120. Yaninovich, Y. YE., et al. (2011). Mizhvidova trofichna konkurentsiya rib, yakikh viroshchuyut' u polikul'turi. Ribogospodars 'ka nauka Ukrainy, 1, 33-38.

121. Moruzi, I. V. (2003). Effektivnost' vyrashchivaniya pelyadi i baykal'skogo omulya (v polikul'ture s karpom) v karpovykh rybovodnykh prudakh Altayskogo kraya. Kholodnovodnaya akvakul'tura: start v 21 vek: Mezhdunar. simp.: mater. Moskva, 131-132.

122. Moruzi, I. V., \& Pishchenko, E. V. (2007). Effektivnost' vyrashchivaniya pelyadi v karpovykh rybovodnykh prudakh yuga Zapadnoy Sibiri. Rybovodstvo $i$ rybnoe khozyaystvo, 3, 19-21.

123. Mukhammed Nagib Bakir. (1993). Intensivnaya tovarnaya prudovaya polikul'tura $\mathrm{v}$ del'te Nila. Doctor's thesis. Astrakhan': Astrakhanskiy tekhnicheskiy institut rybnoy promyshlennosti i khozyaystva.

124. Mukhachev, I. S., (1999). Rekomendatsii po tekhnologii proizvodstva tovarnoy ryby bez primeneniya kombikormov s vykhodom 6-6,5 ts/ga $\mathrm{v}$ rybovodnykh khozyaystvakh yuga Zaural'ya i Zapadnoy Sibiri. Aktual'nye aspekty ryborazvedeniya $v$ sovremennykh usloviyakh. Sankt-Peterburg: KrasNIIRKh; GosNIORKh, 91-95. 
125. Mukhachev, I. S. (2018). Rybokhozyaystvennaya melioratsiya ozer v protsesse vyrashchivaniya tovarnoy pastbishchnoy polikul'tury. Rybovodstvo $i$ rybnoe khozyaystvo, 12, 45-53.

126. Mukhachev, I. S., \& Gunin, A. P. (1999). Pastbishchnaya polikul'tura na vodoemakh Urala i Zapadnoy Sibiri. Sovremennoe sostoyanie $i$ perspektivy razvitiya akvakul'tury. Gorki, 111-112.

127. Neborachek, S. I. (1984). Sadkovoe vyrashchivanie dvukhletkov kanal'nogo soma v polikul'ture s tolstolobikami. Rybnoe khozyaystvo, 38, 52-57.

128. Nekrasova, S. O. (2012). Monitoring i upravlenie gidrokhimicheskoy situatsiey s pomoshch'yu polikul'tury. Sel'skokhozyaystvennoe rybovodstvo: vozmozhnosti razvitiya $i$ nauchnoe obespechenie innovatsionnykh tekhnologiy: Mezhdunar. nauch.-prakt. konf., 5-7 sent. 2012 g.: dokl. Moskva: RGAU-MSKhA, 226-232.

129. Nikonova, R. S. (1983). Biologicheskie osnovy tovarnoy polikul'tury ryb v del'te Volgi. Extended abstract of candidate's thesis. Moskva.

130. Nikonova, R. S. (1977). K otsenke effektivnosti ispol'zovaniya kombikormov pri vyrashchivanii karpa v polikul'ture s rastitel'noyadnymi rybami. Itogi i perspektivy rybokhozyaystvennogo ispol'zovaniya rastitel'noyadnykh ryb: 8 Vsesoyuz. soveshch.: tezisy dokl. Kiev: Naukova dumka, 100-101.

131. Nikonova, R. S. (1977). Nekotorye dannye po pitaniyu i rostu dvukhletok buffalo pri sovmestnom vyrashchivanii $\mathrm{s}$ rastitel'noyadnymi rybami i karpom. Itogi $i$ perspektivy rybokhozyaystvennogo ispol'zovaniya rastitel'noyadnykh ryb: 8 Vsesoyuz. soveshch.: tezisy dokl. Kiev: Naukova dumka, 101-103.

132. Nikonova, R. S. (1999). Rekomendatsii po tekhnologii proizvodstva ryby bez primeneniya kombikormov s vykhodom 8-12 ts/ga v rybovodnykh khozyaystvakh Nizhnevolzhskogo rayona. Aktual'nye aspekty ryborazvedeniya $v$ sovremennykh usloviyakh. Sankt-Peterburg: KrasNIIRKh; GosNIORKh, 89-91.

133. Novozhenin, N. P. (2001). Raduzhnaya forel' kak ob"ekt polikul'tury v prudovom rybovodstve. Rybokhozyaystvennoe ispol'zovanie vodoemov kompleksnogo naznacheniya: sbornik. (Part 2). Moskva, 173-179.

134. Nosal', A. D., \& Suan Lok, Dao. (1972). Vyrashchivanie segoletok belogo tolstolobika sovmestno s belym amurom i karpom v prudakh khozyaystva «Nivka». Rybnoe khozyaystvo, 15, 32-34.

135. Kireeva, I. Yu., et al. (2008). Opyt vyrashchivaniya po organicheskoy tekhnologii molodi rastitel'noyadnykh ryb $\mathrm{v}$ polikul'ture $\mathrm{s}$ besterom. Rybovodstvo $i$ rybnoe khozyaystvo, 4, 16-18.

136. Vasil'eva, L. M., et al. (2018). Osobennosti vyrashchivaniya bestera v prudakh v polikul'ture s rastitel'noyadnymi rybami. Voprosy rybnogo khozyaystva Belarusi, 34, 156-166.

137. Panteley, S. N. (2005). Zakonomernosti formirovaniya ryboproduktivnosti prudov pri pastbishchnom vyrashchivanii karpovykh ryb v polikul'ture. Voprosy rybnogo khozyaystva Belarusi, 21, 136-140.

138. Panteley, S. N. (2005). Zoobentos nagul'nykh prudov pri pastbishchnom vyrashchivanii tovarnoy ryby $\mathrm{v}$ polikul'ture. Akvakul'tura $i$ integrirovannye tekhnologii: problemy i vozmozhnosti: konf.: mater. (Vol. 2). Moskva, 97-100.

139. Panteley, S. N. (2007). Effektivnost' razlichnykh vidov polikul'tur pri pastbishchnom vyrashchivanii tovarnoy ryby. Voprosy rybnogo khozyaystva Belarusi, 23, 324-332. 
140. Panteley, S. N., \& Voronova, G. P. (2016). Vozmozhnosti usovershenstvovaniya priemov vedeniya prudovogo rybovodstva putem optimizatsii polikul'tury ryb i ikh kormleniya. Voprosy rybnogo khozyaystva Belarusi, 32, 96-109.

141. Parkhomenko, A. M. (1985). Povyshenie effektivnosti vyrashchivaniya segoletkov karpa $v$ polikul'ture $s$ rastitel'noyadnymi rybami $v$ usloviyakh rybovodnykh khozyaystv del'ty Volgi. Moskva.

142. Golovkov, G., et al. (1972). Pelyad' - dobavochnaya ryba v prudovom karpovom khozyaystve. Rybovodstvo i rybolovstvo, 1, 8-9.

143. Perspektivy tovarnoy polikul'tury v Egipte. (1994). Rybnoe khozyaystvo: inform. paket. Seriya: Akvakul'tura. Prudovoe i ozernoe rybovodstvo. (Vol. 4). Moskva, 22-24.

144. Polyarush, V. P., et al. (2004). Pilengas v prudovoy polikul'ture. Rybnoe khozyaystvo, 5, 60-62, 78.

145. Pilipenko, Yu. V., Sherman, I. M., \& Shevchenko, V. Yu. (1999). Perspektivy formirovaniya iskusstvennykh ikhtiotsenozov kontinental'nykh vodoemov yuga Ukrainy s ispol'zovaniem novykh ob"ektov akvakul'tury. Sovremennoe sostoyanie $i$ perspektivy razvitiya akvakul'tury. Gorki, 28-30.

146. Plieva, T. Kh. (2007). Vyrashchivanie karasevykh gibridov v mono- i polikul'ture. Rybovodstvo i rybnoe khozyaystvo, 6, 38-43.

147. Yaninovich, Y. YE., et al. (2014). Polikul'tura - shlyakh do intensifikatsii stavovogo ribnitstva. Ribogospodars'ka nauka Ukrainy, 4, 78-83.

148. Ponomareva, E. N., Ba, Mokhamed Lamin, \& Sorokina, M. N. (2007). Ispol'zovanie prudov malykh ploshchadey dlya polikul'tury osetrovykh i rastitel'noyadnykh ryb. Sostoyanie i perspektivy razvitiya fermerskogo rybovodstva aridnoy zony. Moskva, 131-142.

149. Efimova, E. N., et al. (1988). Posledovatel'nost' i sroki posadki ob"ektov polikul'tury v vyrostnye prudy. Sbornik nauchnykh trudov VNIIPRKh, 53, 103-110.

150. Privezentsev, Yu. A., \& Vlasov, V. A. (2004). Polikul'tura. Rybovodstvo. Moskva: Mir, 190-200.

151. Efimova, E. N., et al. (1987). Primenenie raznovozrastnoy polikul'tury ryb v usloviyakh umerennogo klimata. Sbornik nauchnykh trudov VNIIPRKh, 51, 153161.

152. Prikhod'ko, V. A., Tarasova, O. M., \& Sherman, I. M. (1971). Rost i pishchevye vzaimootnosheniya segoletok belogo amura $\mathrm{s}$ karpom pri sovmestnom vyrashchivanii. Rybnoe khozyaystvo, 13, 54-60.

153. Prikhod'ko, V. A., \& Sherman, I. M. (1969). Ekologiya vyrashchivaniya segoletok belogo amura v monokul'ture i sovmestno s karpom. Rybnoe khozyaystvo, 9, 24-29.

154. Efimova, E. N., et al. (1985). Produktsionnye svoystva belogo tolstolobika kak ob"ekta polikul'tury sredney polosy SSSR. Sbornik nauchnykh trudov VNIIPRKh, 45, 26-32.

155. Pushkar', V., \& Dubrovin, V. (1986). Polikul'tura ryb na industrial'noy osnove. Rybovodstvo i rybolovstvo, 1, 8-9.

156. Pshenichniy, D. R. (2009). Efektivnist' viroshchuvannya tovarnikh dvolitok koropovo-sazanovikh gibridiv $\mathrm{v}$ polikul'turi $\mathrm{z}$ trilitkami roslinoidnikh rib za intensivnoyu tekhnologiyeyu. Extended abstract of candidate's thesis. Kyiv: Institut ribnogo gospodarstva Ukrains'koi akademii agrarnikh nauk.

157. Konchits, V. V., et al. (2006). Razvitie fitoplanktona v prudakh Belarusi pri vyrashchivanii v nikh veslonosa. Voprosy rybnogo khozyaystva Belarusi, 22, 108120. 
158. Konchits, V. V., et al. (1995). Rezul'taty opytov po vyrashchivaniyu ryboposadochnogo materiala traditsionnykh i perspektivnykh ob"ektov rybovodstva po intensivnoy tekhnologii. Voprosy rybnogo khozyaystva Belarusi, 13, 77-90.

159. Karachev, R. A., et al. (2007). Resursosberegayushchaya tekhnologiya sovmestnogo vyrashchivaniya osetrovykh i rastitel'noyadnykh ryb $\mathrm{v}$ sadkakh. Ratsional'noe ispol'zovanie presnovodnykh ekosistem - perspektivnoe napravlenie realizatsii natsional'nogo proekta «Razvitie APK»: konf.: mater. Moskva, 166-168.

160. Rudenko, G. P., \& Erik, V. V. (1975). Rezul'taty vyrashchivaniya molodi tsennykh vidov ryb v polikul'ture. Izvestiya GosNIORKh, 99, 206-213.

161. Kireeva, I. Yu., et al. (2008). Rybovodno-biologicheskie osobennosti vyrashchivaniya rastitel'noyadnykh ryb $\mathrm{v}$ polikul'ture $\mathrm{s}$ besterom. Rybovodstvo $i$ rybnoe khozyaystvo, 2, 22-27.

162. Artamonova, T. I., et al. (2006). Ryboproduktivnost' nagul'nykh prudov pri vyrashchivanii polikul'tury rastitel'noyadnykh ryb s karpom i karpokarasem po netraditsionnoy tekhnologii v 1 zone rybovodstva. Sbornik nauchnykh trudov VNIIPRKh, 81, 3-18.

163. Savushkina, S. I., \& Alimov, I. A. (2008). Fiziologo-biokhimicheskaya kharakteristika ryb, vyrashchennykh $\mathrm{v}$ usloviyakh polikul'tury $\mathrm{i}$ po usovershenstvovannoy sisteme kormleniya. Rybovodstvo i rybnoe khozyaystvo, 6 , 47-52.

164. Savushkina, S. I., Petrushin, A. B., \& Alimov, I. A. (2005). Morfofiziologicheskaya kharakteristika molodi obyknovennogo soma (Silurus glanis L.) $\mathrm{v}$ usloviyakh VKN. Akvakul'tura $i$ integrirovannye tekhnologii: problemy $i$ vozmozhnosti: konf:: mater. (Vol. 2). Moskva, 105-109.

165. Sazanov, V. B. (2008). Obosnovanie tekhnologicheskikh elementov vyrashchivaniya chernogo amura $\mathrm{v}$ polikul'ture prudovogo rybovodstva Belarusi. Extended abstract of candidate's thesis. Zhodino.

166. Salazkin, A. A. (1982). Kormovaya baza prudov i ee ispol'zovanie molod'yu sigovykh v usloviyakh polikul'tury. Izvestiya GosNIORKh, 181, 44-53.

167. Sarsembaev, Zh. G., \& Kan, O. M. (1986). Osobennosti vyrashchivaniya plemennogo materiala karpa, tolstolobika i novykh ob"ektov rybovodstva $\mathrm{v}$ polikul'ture. Sbornik nauchnykh trudov VNIIPRKh, 48, 159-165.

168. Servetnik, G. E. (2019). Etologiya i ee rol' v prudovom rybovodstve pri formirovanii polikul'tury. Rybovodstvo i rybnoe khozyaystvo, 1(156), 37-45.

169. Sil'nikova, G. V. (1981). Pitanie i pishchevye vzaimootnosheniya ryb v prudovoy polikul'ture. Izvestiya GosNIORKh, 168, 131-144.

170. Sil'nikova, G. V. (1983). Polikul'tura rastitel'noyadnykh ryb pri vyrashchivanii posadochnogo materiala na rybopitomnike Nikolaevskoy RMS. Izvestiya GosNIORKh, 208, 57-65.

171. Sobolev, Yu. A. (1973). Vyrashchivanie ryboposadochnogo materiala pri polikul'ture. Trudy BelNIIRKh, 9, 37-45.

172. Sobolev, Yu. A. (1972). Povyshenie ryboproduktivnosti prudov pri vyrashchivanii rastitel'noyadnykh ryb s karpom. Trudy BelNIIRKh, 8, 82-88.

173. Subbotina, Yu. M., et al. (1999). Sovershenstvovanie tekhnologii vyrashchivaniya ryboposadochnogo materiala $\mathrm{v}$ polikul'ture s rastitel'noyadnymi rybami v prudakh biologicheskoy ochistki. Resursosberegayushchie tekhnologii v akvakul'ture: simpoz.: mater. dokl. Adler, 102-103. 
174. Kuzov, A. A., et al. (2016). Sovmestnoe vyrashchivanie afrikanskogo soma Clarias gariepinus (Burchell, 1822) i ovoshchnykh sel'skokhozyaystvennykh kul'tur v ustanovkakh zamknutogo vodosnabzheniya (UZV). Kontinental'naya akvakul'tura: otvet vyzovam vremeni: Vseros. nauch.-prakt. konf., Moskva, VVTs, 21-22 yanv. 2016 g.: mater. (Vol. 1). Moskva: VNIIR, 202-206.

175. Sokol'skiy, A. F., \& Molodtsov, A. N. (1999). Osetrovye kak dobavochnyy ob"ekt polikul'tury. Resursosberegayushchie tekhnologii v akvakul'ture: simpoz.: mater. dokl. Adler, 100-101.

176. Bagrov, A. M., et al. (2014). Sposob vyrashchivaniya v polikul'ture molodi karpa i rastitel'noyadnykh ryb. Tekhnologii prudovogo rybovodstva. Moskva: VNIRO, 152-154.

177. Stolovich, V. N., Godlevskaya, N. N., \& Astrenkov, A. V. (2006). Vyrashchivanie segoletkov rastitel'noyadnykh ryb $\mathrm{v}$ rybkhozakh Belarusi. Voprosy rybnogo khozyaystva Belarusi, 22, 205-207.

178. Subbotina, Yu. M., \& Smirnova, I. R. (1999). Perspektivnye ob"ekty dlya razvedeniya $\mathrm{V}$ rybovodno-biologicheskikh prudakh. Sovremennoe sostoyanie $i$ perspektivy razvitiya akvakul'tury. Gorki, 26-28.

179. Sukhoverkhov, F. M. (1966). Biologicheskie osnovy $i$ effektivnost' polikul'tury v prudovom rybovodstve. Moskva: Pishchevaya promyshlennost'.

180. Sukhoverkhov, F. M. (1958). Vyrashchivanie belogo amura, tolstolobika i belogo leshcha v prudakh Rossiyskoy Federatsii. Soveshchanie po akklimatizatsii amurskikh ryb $v$ vodoemakh evropeyskoy chasti SSSR: tezisy dokl. Kiev: Institut gidrobiologii, 6-9.

181. Syrov, V. S., \& Sherman, I. M. (1972). K voprosu o sovmestnom vyrashchivanii segoletok karpa i belogo amura $\mathrm{v}$ eksperimental'nykh usloviyakh. Rybnoe khozyaystvo, 14, 65-69.

182. Tagirova, N. A., Kuz'min, I. A., \& Badaeva, I. Yu. (2005). Gidrobiologicheskiy rezhim vyrostnykh rybovodnykh prudov pri vyrashchivanii segoletkov v polikul'ture. Sbornik nauchnykh trudov VNIIPRKh, 80, 94-102.

183. Tarasova, O. M. (1970). Opyt sovmestnogo vyrashchivaniya karpa i belogo tolstolobika. Rybnoe khozyaystvo, 10, 39-42.

184. Tarasova, O. M. (1971). Osobennosti pitaniya belogo tolstolobika pri vyrashchivanii ego v polikul'ture v prudakh yuga Ukrainy. Doctor's thesis. Kiev.

185. Tereshenkov, I. I. (1979). Biologicheskie osnovy tovarnogo vyrashchivaniya karpa, pelyadi, belogo amura i pestrogo tolstolobika v ozerakh Severo-Zapada. Extended abstract of candidate's thesis. Leningrad.

186. Muratov, V. M., et al. (2006). Tekhnologicheskiy reglament vyrashchivaniya tovarnoy prudovoy ryby $\mathrm{v}$ polikul'ture. Sbornik nauchno-tekhnologicheskoy $i$ metodicheskoy dokumentatsii po akvakul'ture v Belarusi. Minsk: Tonpik, 42-50.

187. Fedorchenko, V. I., et al. (2001). Tekhnologiya vyrashchivaniya posadochnogo materiala i tovarnogo karpa $\mathrm{v}$ polikul'ture s rastitel'noyadnymi rybami na osnove effektivnogo funktsionirovaniya vodnykh ekosistem. Sbornik nauchnotekhnologicheskoy $i$ metodicheskoy dokumentatsii po akvakul'ture. Moskva: VNIRO, 53-59.

188. Tekhnologiya vyrashchivaniya ryby v polikul'ture s vykhodom 5-7 t/ga v prudakh 12 zon rybovodstva. (1986). Moskva.

189. Tekhnologiya nepreryvnogo vyrashchivaniya ryby v prudakh 6-7 zon rybovodstva. (1989). Moskva: VNIIPRKh. 
190. Kharitonova, N. M., ta in. (1996). Tekhnologiya viroshchuvannya tovarnoi ribi $v$ stavakh v polikul'turi. Kyiv: Institut ribnogo gospodarstva UAANs.

191. Stepanov, V. D., et al. (2008). Transformatsiya energii pervichnoy produktsii v ekosisteme nagul'nykh prudov $\mathrm{s}$ intensivnoy polikul'turoy karpa i rastitel'noyadnykh ryb. Sbornik nauchnykh trudov VNIIPRKh, 84, 55-70.

192. Tyutyunik, S. N., Botezat, V. A., \& Goryuk, R. I. (1972). Sovmestnoe vyrashchivanie rastitel'noyadnykh ryb i karpa v prudakh Moldrybkhozstantsii. Biologiya $i$ biotekhnika vyrashchivaniya rastitel'noyadnykh ryb. Kishinev: Shtiintsa, 9-26.

193. Tyutyunik, S. N., Stepanova, G. M., \& Vitkovskaya, E. D. (1977). Sezonnaya dinamika pitaniya i biokhimicheskikh pokazateley rastitel'noyadnykh ryb pri polikul'ture v Moldavii. Itogi i perspektivy rybokhozyaystvennogo ispol'zovaniya rastitel'noyadnykh ryb: 8 Vsesoyuz. soveshch.: tezisy dokl. Kiev: Naukova dumka, 122-124.

194. Fedorchenko, V. I., Trubnikov, A. I., \& Fedorchenko, F. G. (1990). Rybovodnye pokazateli ryby pri vysokom urovne intensifikatsii $\mathrm{v}$ usloviyakh mono- i polikul'tury. Sbornik nauchnykh trudov VNIIPRKh, 60, 119-124.

195. Fedorchenko, F. G., \& Kiselev, A. Yu. (2006). Vyrashchivanie dvukhletkov karpa $\mathrm{v}$ polikul'ture $\mathrm{s}$ preobladaniem rastitel'noyadnykh ryb $\mathrm{v}$ usloviyakh 1 zony rybovodstva. Sbornik nauchnykh trudov VNIIPRKh, 81, 18-21.

196. Fedorchenko, F. G. (2005). Upitannost' i khimicheskiy sostav segoletkov ryb, vyrashchennykh v polikul'ture. Sbornik nauchnykh trudov VNIIPRKh, 80, 63-68.

197. Filippov, K. K. (1985). Ekologicheskie osnovy prudovoy polikul'tury karpa i rastitel'noyadnykh ryb v Altayskom krae. Extended abstract of candidate's thesis. Moskva: VNIIPRKh.

198. Filippov, K. K., \& Filippova, A. V. (1997). Prudovaya polikul'tura i novye ob"ekty rybovodstva v Altayskom krae. Pervyy kongress ikhtiologov Rossii: tezisy dokl. Astrakhan', 300.

199. Filippova, A. V., \& Filippov, K. K. (2001). Rastitel'noyadnye ryby i buffalo v vodnykh ekosistemakh Altayskogo kraya. $8 s^{\prime \prime} e z d$ Gidrobiologicheskogo obshchestva RAN: tezisy dokl. (Vol. 2). Kaliningrad, 66.

200. Litvinova, T. G., et al. (2003). Formuvannya gidrokhimichnogo rezhimu staviv zoni Polissya pri viroshchuvanni ribi v polikul'turi za vipasnoi tekhnologii z dvolitnim tsiklom viroshchuvannya (na prikladi VAT Zabir'ya). Ribne gospodarstvo, 62, 112117.

201. Khabibulin, E. T. (1980). Vliyanie karpa i belogo amura na gidrokhimicheskiy rezhim, pervichnuyu produktsiyu i ryboproduktivnost' prudov Belorussii. Extended abstract of candidate's thesis. Minsk.

202. Kharitonova, N. M., \& Demchenko, I. F. (1993). Rekomendatsii po viroshchuvannyu koropovikh rib $v$ polikul'turi pri pasovishchnomu utrimanni. Kyiv: Institut ribnogo gospodarstva Ukrains'koi akademii agrarnikh nauk.

203. Kharitonova, N. N., Blyskavka, E. A., \& Tarasova, O. M. (1968). Pitanie i rost dvukhletok karpa i belogo amura pri sovmestnom vyrashchivanii. Rybnoe khozyaystvo, 6, 112-117.

204. Kharitonova, N. N., \& Demchenko, I. F. (1993). Rekomendatsii po povysheniyu ryboproduktivnosti prudov pri polikul'ture ryb. Kiev: Ukrainskiy nauchnoissledovatel'skiy institut rybnogo khozyaystva. 
205. Kharitonova, N. N., \& Ivanov, I. N. (1974). Opyt vyrashchivaniya rastitel'noyadnykh ryb sovmestno s karpom. Tekhnologiya proizvodstva ryby. Moskva, 129-133.

206. Khizhnyak, M. I. (1999). Kil'kisniy rozvitok bakterioplanktonu nagul'nikh staviv pri viroshchuvanni koropa $\mathrm{V}$ polikul'turi $\mathrm{z}$ roslinoidnimi ribami. Ribne gospodarstvo, 51, 73-85.

207. Charyev, R., Rylov, V. G., \& Kanoda, N. N. (1980). Opyt vyrashchivaniya segoletkov rastitel'noyadnykh ryb sovmestno s karpom v prudakh Turkmenistana. Sbornik nauchnykh trudov VNIIPRKh, 60,111-119.

208. Chertikhin, V. G. (1992). Biologicheskie osobennosti proizvodstva posadochnogo materiala v polikul'ture $\mathrm{v}$ usloviyakh sredney polosy. Rybnoe khozyaystvo: inform. paket. Seriya: Akvakul'tura. Prudovoe i ozernoe rybovodstvo. (Vol. 2). Moskva, 719.

209. Chertikhin, V. G. (1977). Pishchevye otnosheniya gibrida tolstolobikov s karpom pri sovmestnom vyrashchivanii v usloviyakh sredney polosy RSFSR. Sbornik nauchnykh trudov VNIIPRKh, 18, 116-131.

210. Chertikhin, V. G., Bay, V. S., \& Mel'chenkov, E. A. (1992). Pervyy opyt vyrashchivaniya tovarnykh dvukhletok veslonosa v polikul'ture (s belym i pestrym tolstolobikami, belym amurom i karpom). Rybnoe khozyaystvo: inform. paket. Seriya: Akvakul'tura. Prudovoe i ozernoe rybovodstvo. (Vol. 3). Moskva, 24-31.

211. Chertikhin, V. G., Mel'chenkov, E. A., \& Shagovskiy, S. V. (2000). Polikul'tura rastitel'noyadnykh ryb, karpa i veslonosa pri tovarnom vyrashchivanii. Problemy vosproizvodstva rastitel'noyadnykh ryb, ikh rol'v akvakul'ture: konf.: mater. dokl. Adler, 133-135.

212. Chizhik, A. K., Sherman, I. M., \& Shchechka, E. I. (1977). K voprosu izucheniya effektivnosti polikul'tury $\mathrm{v}$ vysokomineralizovannykh vyrostnykh prudakh. Itogi $i$ perspektivy rybokhozyaystvennogo ispol'zovaniya rastitel'noyadnykh ryb: 8 Vsesoyuz. soveshch.: tezisy dokl. Kiev: Naukova dumka, 138-139.

213. Shandruk, O. M. (1999). Perspektivi pasovishchnogo viroshchuvannya stavkovikh rib v polikul'turi v ribnits'komu gospodarstvi agrofirmi «Zorya». Tavriys'kiy naukoviy visnik, 10, 119-122.

214. Shandruk, O. M., Grib, Y. V., \& Borbat, M. O. (2011). Do pitannya rozrakhunku shchil'nosti posadki koropovikh rib u polikul'turi. Ribogospodars'ka nauka Ukrainy, 4, 69-72.

215. Shekk, P. V., \& Burgaz, M. I. (2017). Umen'shenie organicheskogo zagryazneniya melkovodnykh akvatoriy solonovatovodnykh limanov pri vyrashchivanii ryb v sadkakh v polikul'ture. Ribogospodars 'ka nauka Ukrainy, 2, 29-38.

216. Sherman, I. M. (1971). Vyrashchivanie segoletok belogo amura v monokul'ture i sovmestno s karpom na yuge Ukrainy. Rybnoe khozyaystvo, 12, 78-80.

217. Sherman, I. M. (1971). O pitanii segoletok belogo amura i leshcha pri sovmestnom vyrashchivanii. Rybnoe khozyaystvo, 13, 45-50.

218. Shmakova, Z. I. (2006). Vliyanie raznykh faktorov i tekhnologicheskikh priemov na vyrashchivanie segoletkov v prudovoy polikul'ture (obzor). Sbornik nauchnykh trudov VNIIPRKh, 81, 21-28.

219. Shmakova, Z. I. (2000). Estestvennaya kormovaya baza i ee rol' v pitanii ryb, vyrashchivaemykh v polikul'ture. Problemy vosproizvodstva rastitel'noyadnykh ryb, ikh rol'v akvakul'ture: konf.: mater. dokl. Adler, 139-141.

220. Yaninovich, Y. YE. (2010). Intensifikatsiya stavovogo ribnitstva shlyakhom vprovadzhennya polikul'turi. Ribogospodars 'ka nauka Ukrainy, 1, 79-82. 
221. Yaninovich, Y. YE. (2012). Pidvishchennya efektivnosti stavovogo ribnitstva za rakhunok rozshirennya polikul'turi rib. Extended abstract of candidate's thesis. Kyiv: Institut ribnogo gospodarstva NAANU.

222. Yaninovich, Y. YE., Grinzhevs'kiy, M. V., \& Shvets', T. M. (2011). Pributki vid polikul'turi v ribnitstvi. Ribogospodars 'ka nauka Ukrainy, 1, 89-95.

223. Yaninovich, Y. YE., Gritsinyak, I. I., \& Grinzhevs'kiy, M. V. (2011). Stavova polikul'tura. L'viv: Spolom.

224. Yaninovich, Y. YE., Kachay, G. V., \& Shvets', T. M. (2011). Energetichna tsinnist' m'yasa rib, viroshchenikh u polikul'turi. Ribogospodars 'ka nauka Ukrainy, 2, 122126.

225. Yaninovich, Y. YE., \& Shvets', T. M. (2009). Pidvishchennya vagovikh konditsiy ukrains'kikh koropiv, viroshchenikh u polikul'turi. Rybne hospodarstvo, 67, 210214. 
"Fisheries Science of Ukraine" - a scientific journal, has been published in Ukraine since 2007. "Fisheries Science of Ukraine" included in the List of Specialized Publications of Ukraine, which can be used for publishing results of doctor's and candidate's thesis (biological and agricultural subject specialism - 091, 207), recertification of 17.03 .2020 (decision of Ministry of Education and Science of Ukraine №409)

Founder and publisher of the journal - Institute of Fisheries of the National Academy of Agrarian Sciences of Ukraine State registration certificate KB № 20934-10734 PR of 18.08.2014

\section{EDITOR-IN-CHIEF}

Natalia Matvienko, Doctor of Sciences, Senior Research Scientist, Head of the Department of Ichthyopathology, Institute of Fisheries of the NAAS, UKRAINE

\section{DEPUTY EDITORS-IN-CHIEF}

Ihor Hrytsyniak, Doctor of Agricultural Sciences, Professor, Academician of the NAAS of Ukraine, Director, Institute of Fisheries of the NAAS, UKRAINE

Natalia Kolesnyk, Candidate of Agricultural Sciences, Senior Research Scientist, Head of the Laboratory of International Scientific and Technical Cooperation and Intellectual Property, Institute of Fisheries of the NAAS, UKRAINE

\section{EDITORIAL BOARD}

\section{BIOLOGY}

Daniel Patrick, Doctor of Biological Sciences, Head of Biology Department Laboratories of the Pyrenees and Landes, FRENCH REPUBLIC

Ihor Buzevych, Doctor of Biological Sciences, Senior Research Scientist, Head of the Department of Study Reservoirs Bioresources, Institute of Fisheries of the NAAS, UKRAINE

Leonid Buchatskyi, Doctor of Biological Sciences, Academician of the Russian Academy of Natural Sciences, Leading Research Scientist of the Laboratory of Biotechnologies in Aquaculture, Institute of Fisheries of the NAAS, UKRAINE

Oleksandr Didenko, Candidate of Biological Sciences, Senior Research Scientist, Department of Study Reservoirs Bioresources, Institute of Fisheries of the NAAS, UKRAINE

Vasyl Sondak, Doctor of Biological Sciences, Head of the Water Bioresources Department, National University of Water and Environmental Engineering, UKRAINE

Yuriy Rud', Candidate of Biological Sciences, Senior Research Scientist, Head of the Laboratory of Bio-technology in Aquaculture, Institute of Fisheries of the NAAS, UKRAINE

Oleksandr Potrokhov, Doctor of Biological Sciences, Senior Research Scientist, Head of the Laboratory of Biology of reproduction of fish, Institute of Hydrobiology NAS of Ukraine, UKRAINE

Pavlo Kutishchev, Candidate of Biological Sciences, Associate Professor, Head of the Department of Aquatic Bioresources and Aquaculture, Kherson State Agricultural University, UKRAINE

Liudmyla Dragan, Candidate of Biological Sciences, Senior Research Scientist, Head of the Laboratory of Ecological Studies Institute of Fisheries of the NAAS, UKRAINE

Kruzhilina Svetlana, Candidate of Biological Sciences, Senior Research Scientist, Head of the section of Study Reservoirs Bioresources, Institute of Fisheries of the NAAS, UKRAINE

Oleh Marenkov, Candidate of Biological Sciences, Assistant professor in the Department of General Biology and Water Bioresources, Oles Honchar Dnipro National University, UKRAINE

\section{AQUATIC BIORESOURCES \& AQUACULTURE}

Boris Gomelsky, Doctor of Biological Sciences, Professor, Kentucky State University, UNITED STATES OF AMERICA XU Pao, Doctor, Professor, Director of Freshwater Fisheries Research Center, PEOPLE'S REPUBLIC OF CHINA

Jedrzej Krupinski, Doctor of Sciences, Foreign Member of the National Academy of Agrarian Sciences of Ukraine, Director, National Research Institute of Animal Production, POLAND

Gautam V. Zodape, Doctor of Biological Sciences, Professor, Head of the Department of Zoology of Shivaji University Kolhapur, REPUBLIC OF INDIA

Oleksandr Tretiak, Doctor of Agricultural Sciences, Senior Research Scientist, Deputy Director in scientific works, Institute of Fisheries of the NAAS, UKRAINE

Serhiy Tarasiuk, Doctor of Agricultural Sciences, Professor, Corresponding Member of the National Academy of Agrarian Sciences, UKRAINE

Vitaliy Bekh, Doctor of Agricultural Sciences, Aquaculture Department, National University of Life and Environmental Sciences, UKRAINE

Oleksandr Kostenko, Candidate of Agricultural Sciences, Senior Research Scientist, Head of the Veterinary Medicine and Zootechnics Department, National Academy of Agrarian Sciences of Ukraine, UKRAINE

Tetiana Sharamok, Candidate of Agricultural Sciences, Assistant professor in the Department of General Biology and Water Bioresources, Oles Honchar Dnipro National University, UKRAINE

Liudmyla Chepil, Candidate of Agricultural Sciences, Assistant professor in the Department of Animal Biology, National University of Life and Environmental Sciences, UKRAINE

Zsigmond Jeney, Doctor of Sciences, Honorary Professor of Pannon University, HUNGARY

Denys Breus, Candidate of Agricultural Sciences, Assistant professor in the Department of Ecology and Sustainable Development named after Professor Yu.V. Pilipenko, Kherson State Agrarian University, UKRAINE

\section{SCIENTIFIC EDITORS OF SECTIONS}

are staff employees of the Institute of Fisheries of the NAAS of Ukraine: Natalia Tushnytska, Candidate of Veterinary Sciences, Senior Research Scientist, Scientific Secretary of the Institute of Fisheries of the NAAS; Yaroslav Tuchapskyi, Candidate of Agricultural Sciences, Head of the Carp Breeding Laboratory of the Institute of Fisheries of the NAAS; Olha Zaloilo, Candidate of Biological Sciences, Senior Research Scientist, Head of the Laboratory of Molecular-Genetic Studies of the Institute of Fisheries of the NAAS; Yuriy Zabytivskyi, Candidate of Biological Sciences, Senior Research Scientist of Section of Sturgeon of the Institute of Fisheries of the NAAS; Antonina Mruk, Head of the Laboratory Salmonids Culture of the Institute of Fisheries of the NAAS; Tetiana Hryhorenko, Candidate of Agricultural Sciences, Head of the Laboratory of Hydrobiology and Technology of Invertebrates Cultivation of the Institute of Fisheries of the NAAS; Hanna Kurinenko, pHD of Agricultural Sciences, Senior Research Scientist, Head of the Department of Fish Selection.

Editorial board of the Journal "Fisheries Science of Ukraine”: Institute of Fisheries NAAS, 135, Obukhivska St, Kiev-164, Ukraine, 03164; tel.: +38097 70077 25. http://fsu.ua, info@fsu.ua

Layout design: Natalia Kolesnik, Serhiy Shinkar, Yevheniy Arkhanhelskyi, Oleksandr Bezusyi; Making-up: Yevheniy Arkhanhelskyi, Maria Simon; Literature editing: Tetiana Shvets; Corrector: Hanna Kovalchuk 
